\title{
United States: Publication of Financial Sector Assessment Program Documentation- Detailed Assessment of Observance of Basel Core Principles for Effective Banking Supervision
}

This Detailed Assessment of Observance of Basel Core Principles for Effective Banking Supervision for the United States was prepared by a staff team of the International Monetary Fund. It is based on the information available at the time it was completed in May 7, 2010. The views expressed in this document are those of the staff team and do not necessarily reflect the views of the government of the United States or the Executive Board of the IMF.

Copies of this report are available to the public from

International Monetary Fund • Publication Services 700 19th Street, N.W. • Washington, D.C. 20431

Telephone: (202) 6237430 • Telefax: (202) 6237201

E-mail: publications@imf.org • Internet: http://www.imf.org

\section{International Monetary Fund Washington, D.C.}




\section{FINANCIAL SECTOR ASSESSMENT PROGRAM UNITED STATES OF AMERICA}

BASEL CORE PRINCIPLES FOR EFFECTIVE BANKING SUPERVISION (BCP)

DETAILED ASSESSMENT OF OBSERVANCE

MAY 2010

INTERNATIONAL MONETARY FUND

MONETARY AND CAPITAL MARKETS DEPARTMENT 
4045584 
Glossary 3

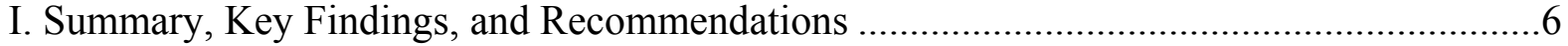

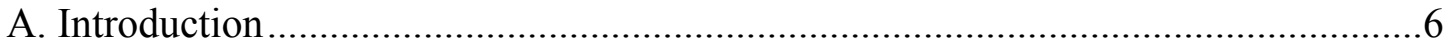

B. Information and Methodology Used for Assessment.............................................

C. Institutional and Macroeconomic Setting and Market Structure-Overview...........9

D. Preconditions for Effective Banking Supervision............................................. 10

E. Market Discipline and Corporate Governance .................................................. 12

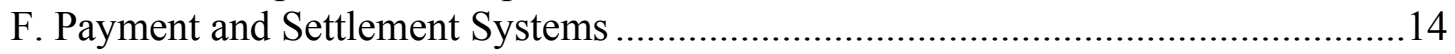

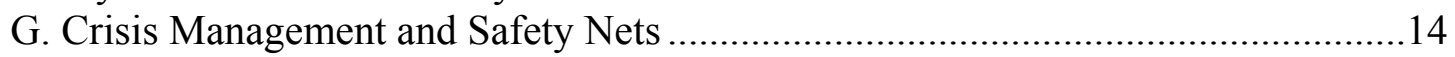

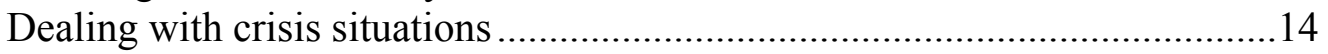

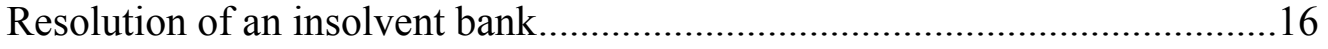

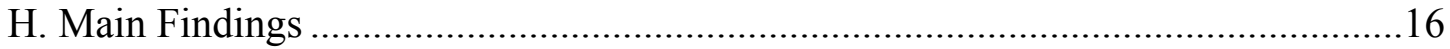

Objectives, independence, powers, transparency, and cooperation (CP 1) ....16

Licensing and structure (CPs 2-5) ........................................................... 17

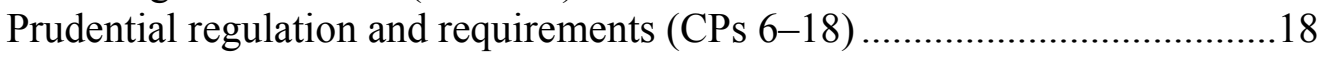

Methods of ongoing banking supervision (CPs 19-21)...............................21

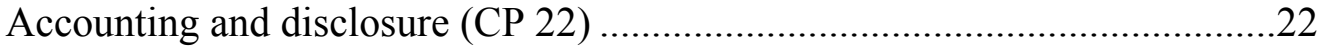

Corrective and remedial powers of supervisors (CP 23) ..............................22

Consolidated and cross-border banking supervision (CPs 24-25) .................23

I. Recommended Action Plan and Authorities' Response.......................................116

Tables

1. Summary Compliance with the Basel Core Principles_-Detailed

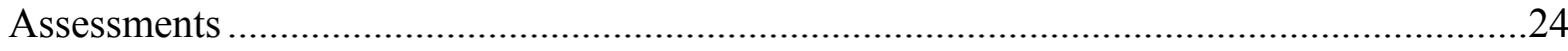

2. Detailed Assessment of Compliance with the Basel Core Principles................................29

3. Recommended Action Plan to Improve Compliance with the Basel Core Principles 


\section{GLOSSARY}

AICPA American Institute of Certified Public Accountants

ALLL Accounting for Loan and Lease Losses

AML/CFT

ATRR

Anti-Money Laundering and Combating the Financing of Terrorism

BCBS

Allocate Transfer Risk Reserve

$\mathrm{BCP}$

$\mathrm{BHCs}$

Basel Committee on Banking Supervision

BHCPR

Basel Core Principles for Effective Banking Supervision

BSA

Bank Holding Companies

Bank Holding Company Performance Report

Bank Secrecy Act

CBEM

Capital adequacy, Asset quality, Management,

CDOs

CDD

Earnings, Liquidity, and Sensitivity to Market Risk

CDR

Commercial Bank Examination Manual

CEO

Collateralized Debt Obligations

Customer Due Diligence

$\mathrm{CFO}$

Central Data Repository

Chief Executive Officer

CFP

Chief Finance Officer

CFR

Contingency Funding Plans

CFTC

Code of Federal Regulations

CHIPS

CIBC

CIP

Commodity Futures Trading Commission

Clearing House Interbank Payments System

Change in Bank Control Act

CMBS

Customer Identification Program

CORE $\quad$ Capital A

Commercial Mortgage Backed Securities

$\mathrm{CP} \quad$ Core Principle

CPC Central Point of Contact

CPP Capital Purchase Program

CRE Commercial Real Estate

CTRs Currency Transaction Reports

DIF Deposit Insurance Fund

DOJ Department of Justice

EC European Commission

EIC Examiner-in-Charge

FAS Financial Accounting Standards

FASB Financial Accounting Standards Board

FATF Financial Action Task Force

FBA Federal Banking Agencies

FBO Foreign Banking Organizations

FDIC Federal Deposit Insurance Corporation

FDI Act Federal Deposit Insurance Act

FEDWIRE The Federal Reserve Banks' Fedwire Funds Services

FFIEC Federal Financial Institutions Examination Council 


\begin{tabular}{|c|c|}
\hline FHCs & Financial Holding Companies \\
\hline FinCEN & Financial Crimes Enforcement Network \\
\hline FRB & Federal Reserve Board \\
\hline FSAP & Financial Sector Assessment Program \\
\hline FTE & Full-time Equivalent \\
\hline GAAP & Generally Accepted Accounting Principles \\
\hline GAAS & Generally Accepted Auditing Standards \\
\hline $\mathrm{GAO}$ & Government Accountability Office \\
\hline GLB Act & Gramm-Leach-Bliley Act of 1999 \\
\hline GSE & Government-Sponsored Enterprises \\
\hline HOLA & Home Owners' Loan Act \\
\hline ICERC & Interagency Country Exposure Review Committee \\
\hline IG & Inspector General \\
\hline ILCs & Industrial Loan Companies \\
\hline IMF & International Monetary Fund \\
\hline IRR & Interest Rate Risk \\
\hline IT & Information Technology \\
\hline ITS & IT Subcommittee \\
\hline KYC & Know-Your-Customer \\
\hline MDPS & Multi-Regional Date Processing Services \\
\hline MOECA & $\begin{array}{l}\text { Management Ability; Operations, Internal Controls, and Auditing; } \\
\text { Earnings; Compliance; and Asset Management }\end{array}$ \\
\hline MOU & Memorandum of Understanding \\
\hline MRA & Market Risk Amendment \\
\hline MSRs & Mortgage Servicing Rights \\
\hline MTM & Mark to Market \\
\hline NMSRs & Non-Mortgage Servicing Rights \\
\hline NPV & Net Portfolio Value \\
\hline $\mathrm{OCC}$ & Office of the Comptroller of Currency \\
\hline OFAC & Office of Foreign Assets Control \\
\hline OTC & Over-the-Counter \\
\hline OTS & Office of the Thrift Supervision \\
\hline PCA & Prompt Corrective Action \\
\hline PCAOB & Public Company Accounting Oversight Board \\
\hline PCCRs & Purchased Credit Card Receivables \\
\hline PEPs & Politically Exposed Persons \\
\hline PWG & The President's Working Group on Financial Markets \\
\hline $\mathrm{RFI} / \mathrm{C}$ & Risk Management; Financial Condition; Impact / Composite \\
\hline RMS & Records Management System; Risk Management Solutions \\
\hline ROCA & Risk Management; Operational Controls; Compliance; and Asset Quality \\
\hline ROE & Return on Equity \\
\hline ROI & Report of Investigation \\
\hline RTGS & Real Time Gross Settlement System \\
\hline SABR & Statistical Assessment of Bank Risk model \\
\hline SAR & Suspicious Activity Report \\
\hline SCAP & Supervisory Capital Assessment Program \\
\hline
\end{tabular}


SCOR Statistical CAMELS Off-site Rating

SEC Securities and Exchange Commission

SLHCs Savings and Loan Holding Companies

SNC

Shared National Credit Program

SOI Summary of Investigations

TARP Troubled Asset Relief Program

TFR Thrift Financial Report

TSP Technology Service Provider

UBPR Uniform Bank Performance Reports

UFIRS Uniform Financial Institutions Ratings System

URSIT Uniform Rating Systems

UTPR Uniform Thrift Performance Reports

U.S. GAAP U.S. Generally Accepted Accounting Standards 


\section{SUMmary, Key Findings, AND RECOMMENDATIONS}

1. This assessment of the United States against the Basel Core Principles (BCPs) is being undertaken in the immediate aftermath of a period of extreme market stress and continued general economic downturn. The resilience of the U.S. banking system, as well as the complex regulatory and supervisory arrangements that oversee it, has been severely tested. Serious weaknesses that contributed to the stress have been revealed and need to be dealt with effectively. The causes of the financial crisis were many and cannot be identified simply through the lens of the BCPs, but they do identify shortcomings that were material in the run-up to the crisis, many of which were not unique to the U.S. In this assessment, three key weaknesses in the U.S. have been identified: (i) a complicated regulatory structure that necessitates a heavy burden of cooperation and coordination between agencies; (ii) legislative provisions that have hindered and discouraged strong consolidated supervision; and (iii) certain material weaknesses in the oversight of banks' risk monitoring and risk management practices.

2. At the time of the assessment, a wide-ranging set of legislative reform proposals had already been developed by the U.S. Treasury Department to address the weaknesses identified by the financial crisis; these reforms are designed to have a broader reach than the issues noted above. Given that the legislative reforms are continuing to be evaluated, it is not possible in this assessment to judge, or give credit for, their effectiveness. Equally, regulatory reform legislation will not be effective by itself and will require on-going vigilance and 'the will to act' on the part of those tasked with supervising the U.S. banking system.

\section{A. Introduction}

3. This assessment of the current state of the U.S. implementation of the Basel Core Principles for Effective Banking Supervision has been completed as part of a Financial Sector Assessment Program undertaken by the International Monetary Fund during October-November 2009, and reflects the regulatory and supervisory framework in place as of the date of the completion of the assessment. Importantly, it is not intended to assess the merits of the wide-ranging program of reforms currently being proposed and adopted within the U.S. An assessment of the effectiveness of banking supervision requires a review of the legal framework, both generally and as specifically related to the financial sector, and a detailed examination of the policies and practices of the institutions responsible for banking supervision. In line with the BCP methodology, the assessment focused on the major banks and holding companies, and their regulation and supervision, given their importance to the system. 


\section{B. Information and Methodology Used for Assessment}

4. The assessment team ${ }^{1}$ reviewed the legal framework for banking supervision, held extensive discussions with the staff of the Federal Reserve System, the Office of the Comptroller of Currency (OCC), the Federal Deposit Insurance Corporation (FDIC), the Office of Thrift Supervision (OTS), the U.S. Treasury, the Government Accountability Office, the Office of Inspector Generals, the Federal Financial Institutions Examination Council, the New York Department of State Banks, the Conference of State Bank Supervisors, industry associations representing domestic and foreign banks, think-tanks and private sector participants in the banking and financial markets. The team examined the current practice of on-site and off-site supervision of the Federal supervisory agencies. The assessment team had the benefit of working with a comprehensive self-assessment completed by the U.S. agencies, enjoyed excellent cooperation with its counterparts, and received the information it required. The team extends its thanks to the staff of the various agencies and the Treasury for their participation in the process and their comprehensive self-assessment.

\section{For context, it is important to note that the United States is the first complex} economy to have a full review under the BCPs that were revised in 2006. This is significant for two reasons: (i) the revised BCPs have a heightened focus on risk management and its practice by supervisory authorities and the supervised institutions; and (ii) the standards are evaluated in the context of a financial system's sophistication and complexity. Therefore, the expectations applied in evaluating U.S. compliance with the BCPs were high. These factors should be taken into account in any comparisons between the U.S. assessment and previous FSAPs for other countries.

6. Reaching conclusions required judgments by the assessment team. Banking systems differ from one country to another, as do their domestic circumstances. Furthermore, banking activities are changing rapidly around the world after the crisis, and theories, policies, and best practices for supervision are swiftly evolving. Nevertheless, by adhering to a common, agreed methodology, the assessment should provide the U.S. authorities with an internationally consistent measure of the quality of its banking supervision in relation to the revised Core Principles, which are internationally acknowledged as minimum standards

7. The assessment of compliance with each principle is made on a qualitative basis. A four-part assessment system is used: compliant; largely compliant; materially noncompliant; and non-compliant. To achieve a "compliant" assessment with a principle, all essential criteria generally must be met without any significant deficiencies. A "largely compliant" assessment is given if only minor shortcomings are observed, and these are not seen as sufficient to raise serious doubts about the authority's ability to achieve the objective

\footnotetext{
${ }^{1}$ The BCP assessment was conducted by Wayne Byres (Executive General Manager, Australian Prudential Regulation Authority), Nicholas Le Pan (IMF Consultant; ex-Head of the Office of the Superintendent of Financial Institutions, Canada and ex-Vice Chairman of the Basel Committee for Banking Supervision), and Goran Lind (Adviser to the Swedish Riksbank and longtime member of the Basel Committee).
} 
of that principle. Under the BCP methodology a "materially non-compliant" assessment is given whenever there are severe shortcomings, despite the existence of formal rules, regulations and procedures, and there is evidence that supervision has clearly not been effective, that practical implementation is weak, or that the shortcomings are sufficient to raise doubts about the authority's ability to achieve compliance. Assessors have rated one CP materially non-compliant, but believe, based on evidence during the assessment that the FBAs are strongly willing and able to achieve compliance. A "non-compliant" assessment is given when no substantive progress toward compliance has been achieved. In interpreting ratings, it is also important to note that for some CPs the assessment takes into account both compliance at banks and compliance of the supervisors.

8. The U.S. financial structure is fundamentally different from some countries, in that it has advanced and well-developed capital markets, and diverse sources of credit; this means that the banking system in a traditional sense is a smaller part of the broader financial system. The assessment of the banking supervisory system against the BCPs therefore did not cover the entire regulatory system, which would be the case in some other countries. The scope of the BCP assessment did not extend, for example, to the supervisory arrangements for the government-sponsored enterprises (GSEs) and other government-sponsored credit providers, non-bank mortgage originators and brokers, nor to the oversight of smaller community-based, bank-like organizations such as credit unions. The recent financial crisis, however, showed how developments in these non-bank parts of the system can materially affect the banking system, and the assessment must be viewed in light of these restrictions. The diversity of the U.S. banking and non-banking system needs to be borne in mind in any assessment of the banking regulatory structure.

9. The approach taken by the assessors in assessing BCP compliance has been to examine whether the four Federal banking agencies (FBAs) - the Federal Reserve, the OCC, the OTS, and the FDIC - by themselves provide sufficiently effective supervision to meet the requirements of the BCPs. Since almost all banks ${ }^{2}$ in the U.S. have a primary FBA to oversee them, the assessors did not seek, nor have the capacity, to test the strength and capability of each and every state banking supervisor. Where the assessors have concluded there may be gaps or shortcomings in the operations of the FBAs relative to the BCPs, the assessors have considered whether the work of the state banking agencies would be sufficient to compensate.

10. The use of holding company structures ${ }^{3}$ to own and operate banks is a fundamental component of the U.S. banking system, and this is recognized within the

\footnotetext{
2 "Banks" includes Federal Reserve members - all FDIC-insured national banks (supervised by the OCC) and FDIC-insured state-chartered banks (supervised by the Federal Reserve)and nonmembers (supervised by the FDIC); and FDIC-insured savings associations (supervised by the OTS) unless the context indicates otherwise.

3 "Holding companies" includes both bank holding companies and savings and loan holding companies except in cases where there is a material difference between them (in terms of legal authority, operations, or structure). Where an aspect of the U.S. system refers only to
} 
banking supervisory arrangements that have been established. Although the BCPs refer generically to "banks" in many places, the assessors have adopted a wider interpretation to incorporate the supervision of bank and thrift holding companies. This follows the approach adopted by the U.S. in its own self-assessment, which treated the supervision of holding companies as an integral component of the system for bank supervision.

\section{Institutional and Macroeconomic Setting and Market Structure-Overview}

11. The U.S. financial system is large and highly diversified. At end-2007, total U.S. financial assets amounted to almost four and a half times the size of GDP. Of this, however, less than a quarter of total financial assets were accounted for by traditional depository institutions. Other important sectors include pension and other investment funds (each representing about 18 percent of total financial assets) and insurance companies (11 percent of total assets). The depth and diversification of the U.S. financial sector is reflected in the relatively low reliance of the corporate sector on bank credit (around 10 percent). GSEs play a significant role in the U.S. financial sector. At end-2007, they accounted for 20 percent of total financial assets, mostly concentrated in the mortgage markets.

12. The crisis has radically changed the shape of the U.S. financial system in a short timeframe. The top investment banks recently have been reconfigured as bank holding companies, nonbanks severely weakened, the housing GSEs are now in government conservatorship, and private securitization remains dormant. There are signs that securitization is picking up, thanks to the supervisory policy responses and the prompt development and implementation of various government support programs. How the securitization structure and markets change going forward is yet unclear, but they may be more bank-centered and (at least initially) more concentrated. The capital adequacy of the large BHCs has been bolstered by the U.S. Capital Purchase Program (CPP). Although none of the top financial institutions breached minimum regulatory requirements during the financial turmoil, the perceived quality of their assets and lack of general market confidence inflicted a severe blow to their perceived resilience to shocks. After the publication of the authorities' stress test results in early-May 2009, the 19 top BHCs were able to raise nearly US $\$ 200$ billion capital (of which 63 percent was in the form of common equity), and to repay US\$74.4 billion of CPP preferred shares. The 10 BHCs needing an additional Supervisory Capital Assessment Program (SCAP) buffer increased their Tier 1 common equity by more than US\$77 billion in Tier 1 common equity by their deadline of November 2009. In addition, as of early February 2010, 13 of the participating BHCs have fully redeemed their US\$156.7 billion of preferred shares under the Treasury's CPP and another five have either announced or taken steps to do so in the near future.

13. After the crisis, asset quality has continued to deteriorate, despite an aggressive policy of loan loss provisioning. In the third quarter of 2009, banks' nonperforming loans

bank holding companies (BHCs) or savings and loan holding companies (SLHCs), it is so indicated in the text. 
rose to 4.9 percent of total loans and net charge-offs rose to 2.7 percent, the highest levels for both in the 26-year history of such recorded data. Authorities expect further write-downs and charge-offs to emerge for some time. Furthermore, although there are signs of improvements in some subsectors, these indicators are likely to further deteriorate if jobless rates continue to rise.

14. After a sharp contraction, the U.S. economy appears to have hit bottom in the second quarter of 2009 and is showing signs of recovery, although underlying economic activity remains weak. GDP declined by 6.4 percent in 2009 Q1 and 0.1 percent in Q2 at an annual rate. A concerted policy response - comprising aggressive monetary policies, a sizable fiscal stimulus, and efforts to stabilize financial systems - has bolstered confidence, supported demand, and reduced systemic risks. In particular, after lowering the policy rate to the $0-25$ basis points range in December 2008, the Federal Reserve expanded its range of "credit easing" measures and in January 2009 indicated that conditions were likely to warrant an exceptionally low rate for an extended period. A fiscal stimulus of some 5 percent of GDP over fiscal years 2009-11 is lending increasing support to demand and U.S. financial supervisors' significant efforts to stabilize the financial system have contributed to a substantial improvement in financial conditions, largely easing the post-Lehman credit crunch. An issue is whether the present buoyancy in some financial markets is sustainable.

15. Looking ahead, the near-term outlook is for the gradual recovery to continue, albeit slower than the typical recovery in previous cycles, with growth returning to a lower trend only in mid-2010. The process of rebuilding household and financial intermediaries' balance sheets and relatively feeble labor market conditions will pose headwinds to demand for some time. Unemployment is expected to continue rising, cresting slightly below 10 percent in 2010; households' net worth fell by some US\$11 trillion during 2008; banks face continued pressure from a challenging credit cycle; and financial conditions, while significantly improved from severely stressed levels, remain strained as key markets continue to depend heavily on policy support. On the positive side, the recent rapid pace of destocking portends some upside to production, although the strength of both domestic and foreign demand remains in question. Overall, IMF staff forecasts an annual contraction of 2.5 percent in 2009 followed by growth of 2.7 percent in 2010 .

16. Looking to the medium term, the post-crisis trend rate of U.S. growth is expected to be lower than the pre-crisis trend. The protracted recession and tighter financial conditions will crimp capital accumulation, and high and persistent unemployment will boost equilibrium unemployment; both these factors will lower potential growth.

\section{Preconditions for Effective Banking Supervision}

17. Overall, the public infrastructure supporting effective banking supervision in the U.S. is well-developed. That said, the complexities inherent within it, ${ }^{4}$ and the lessons

\footnotetext{
${ }^{4}$ Under the Federal system of the United States, the Federal Government has considerable authority, while individual states retain significant authority and responsibility. This structure has resulted in a complex and, at times, fragmented system of laws and regulations.
} 
learned from the recent financial crisis, demonstrate scope for enhancements to further improve its resilience.

18. Business laws in the United States, including contract, bankruptcy, and property law, are well-developed and reliable. Contract law is established by the combination of common law and state statute. The enforceability of contracts is well-established and enforced by the courts. Laws establishing the enforceability of security interests (i.e., interests in property conveyed to collateralize loans) are governed, primarily, under Article 9 of the Uniform Commercial Code. The enforcement of mortgages of real property is upheld under (non-uniform) state laws. Federal bankruptcy laws incorporate protections for both creditors and debtors. Property rights are protected under the Bill of Rights of the United States Constitution and under state laws.

19. Business law disputes are typically resolved in state trial courts of general jurisdiction. Federal courts are available when the claim involves federal law or when a state law claim involves parties from different states. A right of appeal exists in both the federal and state systems. Contracts, both commercial and consumer, may also provide for mandatory arbitration rather than dispute resolution through the courts.

20. The U.S. possesses an independent judiciary and well-regulated accounting, auditing, and legal professions. The judicial system is comprised of both federal and state systems. Judges in both federal and state courts must be members of the bar and generally have significant experience as practicing lawyers before becoming judges. Federal judges are appointed by the President with the advice and consent of the Senate and receive lifetime appointments. States vary in their methods of judicial appointment. Some follow a system similar to the federal system, i.e., the state governor appoints judges with some input from the legislature. Some states, however, appoint judges through a general election.

21. Lawyers must receive a license to practice law from a state or states. All states but one (Wisconsin) require applicants who are not already members of another state's bar to pass a bar examination prior to receiving a license. In addition to controlling admission into the profession, the states also regulate the profession. Regulation is often delegated to a selfregulatory organization, i.e., a state bar association. Lawyers are also subject to ethical standards set by the states.

\section{U.S. accounting standards (U.S. GAAP) are established by the Financial}

Accounting Standards Board (FASB). U.S. GAAP has been the most widely accepted accounting framework internationally for many decades, although the International Financial Reporting Standards (IFRS) that have been produced under the auspices of the International Accounting Standards Board (IASB) in recent years have taken over this mantle. Both the FASB and IASB are currently working on a convergence program, designed to bring U.S. and international accounting standards into a single framework. However, recent statements by the IASB and the FASB have raised issues of possible divergence in the approach to accounting for financial investments; this is an issue that is important to banks and bank supervisors, but the outcome remains to be seen. Both standard setters are also examining the lessons learned from the financial crisis, as accounting standards (particularly the use of fair value accounting, and the methodology for loan loss provisioning in banks) have been 
criticized in some quarters as contributing to financial instability (see paragraph 29 for a more in-depth discussion).

23. Financial statement audit requirements are robust, having been considerably strengthened in 2002 with the passage of the Public Company Accounting Reform and Investor Protection Act (also known as the Sarbanes-Oxley Act). The Sarbanes-Oxley Act enhanced audit scrutiny, toughened auditor independence requirements, required various management attestations about the reliability of financial accounts, and expanded disclosure requirements with the objective of providing the users of financial statements with greater security as to their accuracy and reliability.

\section{The recent U.S. Treasury White Paper on Financial Regulatory Reform found} gaps within the broader regulation of financial markets. Proposals are currently being considered by Congress to include a program of measures to establish a framework for the comprehensive regulation of financial markets, including (i) systemic risk oversight, (ii) a resolution regime for complex financial firms, (iii) strengthened regulation and supervision of securitization markets, (iv) comprehensive regulation of all over-the-counter (OTC) derivatives (including credit default swaps), (v) harmonization of futures and securities regulation, and (vi) strengthening of the oversight, settlement capabilities, and liquidity of systemically important payment, clearing, and settlement systems. An additional suite of reforms is being proposed to improve consumer and investor protection.

25. One cause of the financial crisis is that the credit culture had eroded materially over time, as lenders increasingly required less equity and/or collateral from borrowers; this applied to both mortgage and corporate/leveraged borrowers. A number of factors appeared to play a role in this: (i) a stable macroeconomic environment with low interest rates, (ii) a public policy that provided incentives for lending to home owners by banks and non-banks alike, and (iii) competition from the non-bank/unregulated sector. The reliance on the originate-to-distribute business model (which made underwriters complacent about lending standards), a corresponding lack of scrutiny by capital markets, and end investors who provided finance (which allowed funding to continue to flow to poor quality credits), also played a significant role. Many off-balance sheet exposures proved to be opaque and insufficiently distant; under stress they had to be brought back onto bank balance sheets in order to maintain investor relations and banks' reputations.

\section{E. Market Discipline and Corporate Governance}

26. There is a considerable infrastructure in the U.S. that promotes and supports market discipline. This includes a well-developed system of continuous disclosure obligations by public companies, extensive disclosure obligations for certain other investments, active rating agencies and an analyst community which disseminates its views through multiple media. As a result, major banks disclose considerable quantitative and qualitative information quarterly and annually. This will be enhanced as a result of adoption of Basel II for advanced banks. U.S. Banking Laws provide additional opportunities for the operation of market discipline through a requirement that banks and their holding companies provide detailed financial information regarding their operations to shareholders, depositors, and the general public. 
27. Through an inter-agency coordinating group, the FBAs regularly publish bank performance reports, which show in detail how individual institutions compare with their peers. Formal enforcement actions brought by the FBAs are routinely made public.

28. Following the recent crisis, weaknesses have been revealed in this infrastructure. Credit rating agencies have been criticized for inappropriate ratings approaches and methodologies related to structured products and certain mortgage backed securities, and inadequate transparency about their methodology and the risks they are and are not rating. This has led to questioning of the suitability of the use of such ratings in regulatory policies. In addition, the opaqueness of complex structured products has been mentioned as a contributor to market disruption when the quality of underlying sub-prime assets was called into question and it was difficult for holders of these investments to assess their true value. Inadequate information on the exposures of the so-called "shadow banking system"-structured investment vehicles and hedge funds-has led to proposals for them to register and furnish basic information to securities regulators and the markets.

29. While market discipline and transparency are based on the robust accounting standards set by U.S. GAAP, the recent crisis has led policymakers and accounting standard setters to consider areas for improvement. Two key matters relevant for banks are the standards for accounting for financial instruments and those for loan loss provisioning. For financial instruments required to be 'fair valued,' it is now recognized that there were problems with the reliability of valuation of such assets that were not widely traded. For loan loss provisioning, the issue is the degree to which the accounting model now in effect for loans and certain other assets can be modified to permit more forward-looking provisioning. Bank regulators would naturally prefer more forward-looking provisioning while accounting standard setters want to ensure that opportunities for income smoothing are minimized. A number of observers believe that the U.S. application of this standard in practice allows for less forward-looking provisioning than does the equivalent IASB standard. Some would like to alter the current standard, while others would prefer to replace it with a comprehensive fair value requirement for all financial instruments including loans. Given the experience of fair values in the recent crisis (including volatility induced by the standards), some banks, and banking regulators generally, have expressed doubts about the latter possibility.

30. Comprehensive corporate governance rules primarily arise from state corporations laws, as well as federal law requirements for publicly held companies, relating to financial disclosure and the auditing process, and internal controls over financial disclosure. The same is generally true for banks, whether licensed under state or federal law. They must also have an audit committee that meets certain criteria for independence. Governance arrangements have been criticized for such matters as flawed board member selection, failing to separate the CEO from the board Chair position, complex proxy and proposal procedures that make it difficult for shareholders to replace directors, and poorly designed compensation schemes that exacerbate the tendency to focus on short-term results. Notwithstanding the legal framework for shareholder rights already in place, the Securities and Exchange Commission (SEC) and the U.S. administration have made proposals to strengthen shareholder rights to nominate board members and to have a voice in matters relating to executive compensation. 
31. Developments in the areas of corporate governance, accounting standards, and regulation of non-bank entities could have a material impact on improving the environment for banking regulation and supervision by reinforcing sound regulatory practices. Other possible changes, such as extending fair value accounting to banks' entire loan portfolios, could weaken the safety and soundness infrastructure. In addition, failure to act in certain areas such as introducing more forward-looking loan provisioning could make bank regulation more difficult going forward. Bank regulators, both domestically and internationally, are rightly actively involved in deliberations on these issues. To the extent that policy developments make regulation for safety and soundness materially more difficult, regulators will need to be ready to take compensating action.

\section{F. Payment and Settlement Systems}

32. The wholesale payment infrastructure in the United States comprises two systems, which are of systemic importance and settle in central bank money. The Federal Reserve Banks' Fedwire Funds Services (Fedwire) is a real time gross settlement system (RTGS) operated by the central bank, and the Clearing House Interbank Payments System (CHIPS) is a private sector system combining net and gross real time settlement. The retail payment infrastructure employs a number of public and private sector Automated Clearing Houses, regional and interregional check exchanges and card payment schemes. None of these is considered to be systemically important. The payment and settlement systems performed well throughout the recent period of market stress despite the significant challenges arising from unprecedented financial market stresses, higher than normal and more-variable payment and settlement volumes and values, the financial difficulties of a number of individual financial institutions, including the systems' implementation of failure management procedures, as well as a higher degree of uncertainty regarding counterparty risk. The IMF FSAP mission attributes the stability and smooth functioning of U.S. payment systems during the crisis to various factors, including primarily the robustness of their settlement and operational risk management frameworks and the massive liquidity support provided to the private sector participants by the authorities. At the same time, payments occurring late in the day in the RTGS system and the concentration of payment and clearing activities on a few players have been identified as a source of potential vulnerability in the wholesale payment systems.

\section{G. Crisis Management and Safety Nets}

\section{Dealing with crisis situations}

33. U.S. banking laws provide the FBAs with a broad range of remedial powers; these range from requiring an institution to adopt a resolution of its board of directors formally committing the bank to implement specified corrective actions through issuance by the supervisor of a formal cease and desist order that is enforceable through injunctions entered by a Federal Court. Civil money penalties may be levied by the FBAs against banks, holding companies, and parties affiliated with these institutions, including officers, directors, controlling shareholders, and independent contractors, such as attorneys, accountants, and appraisers. Furthermore, a Prompt Corrective Action (PCA) regime has been provided that requires the FBAs to institute receivership proceedings within 
90 days when tangible equity falls below 2 percent of a bank's assets or to take other appropriate action with the concurrence of the FDIC. PCA triggers action by banks and FBAs earlier, as soon as capital falls below "well-capitalized" threshold of 6/10 percent (Tier $1 /$ Total capital). However, banks normally hold capital well above this well-capitalized level to minimize the chance of breaching the threshold and triggering the PCA regime. Authority to institute conservatorship proceedings, though infrequently invoked, enables the FDIC to control a troubled institution without closing it while a permanent resolution of the bank is sought.

34. A deposit insurance scheme, sponsored by the FDIC, insures all deposits at insured banks up to US\$250,000 per depositor. ${ }^{\mathbf{5}}$ Deposit insurance assessments are riskbased; hence a bank will pay a higher premium if assessed as having potentially higher risks, less capital, or other weaknesses. The FDIC uses ex-ante funding and includes provisions for replenishing the Deposit Insurance Fund (DIF) through emergency assessments and, when necessary, borrowings from Treasury. Due to the current and expected demands on the DIF, insured institutions paid, in 2009, an advance premium for the coming three-year period. The DIF may be used, on a least-cost basis, either to compensate depositors or to facilitate the resolution of the failed bank, typically through a purchase-and-assumption transaction.

35. The Federal Deposit Insurance (FDI) Act includes a systemic risk exception. This requires the Federal Reserve Board of Governors and the FDIC Board of Directors to recommend (by a $2 / 3$ vote of the respective Boards) to the Secretary of the Treasury that a systemic risk determination be made. The Secretary of the Treasury (in consultation with the President), then makes the systemic risk determination and finds that the systemic risk exception should be invoked, which determination concludes that compliance with the least cost requirements of the FDI Act would have a serious adverse effect on economic conditions or financial stability, and that any action or assistance would avoid or mitigate such adverse effects on the banking industry. Subject to these conditions, the exception permits the FDIC to take a wide range of actions.

36. The President's Working Group on Financial Markets (PWG), created in 1988 by Executive Order, consists of the Secretary of the Treasury, Chairman of the Fed, and Chairs of the SEC and Commodity Futures Trading Commission (CFTC). The PWG, working with the Federal supervisors that are not members, has been a means through which the U.S. Government has coordinated its response to the current financial crisis.

37. The Federal Reserve Bank's emergency lending assistance capability includes authority to provide liquidity assistance to (i) solvent but illiquid banks, (ii) undercapitalized banks certified by their primary supervisor to be viable, and (iii) any individual, partnership, or corporation "in unusual and exigent circumstances" when the borrower is unable to obtain financing from banks. The Fed has used this authority in the

\footnotetext{
${ }^{5}$ The amount of insurance was temporarily increased from US\$100,000 to US\$250,000 until year-end 2013.
} 
current financial crisis to provide support to financial institutions and even to non-financial entities through its support of the commercial paper market and through other means.

\section{Resolution of an insolvent bank}

38. The FDI Act provides a comprehensive scheme for the resolution of an insolvent bank. All state and federally chartered banks that conduct retail deposit taking operations in the United States have their deposits insured by the FDIC. The FDI Act provides a comprehensive definition of insolvency that includes a balance sheet test, a liquidity test, and various tests of viability. This authority, and the "prompt corrective action" provisions, authorizes a bank to be placed in receivership or be otherwise resolved before its capital has been exhausted.

39. As Receiver, the FDIC has available to it a broad array of tools to facilitate the process of resolving the insolvent bank. These include authority to engage in purchase and assumption transactions, insured deposit transfers, loss-sharing arrangements, puts for troubled assets, and the utilization of bridge banks. Whenever feasible, the FDIC prepares for closing the bank well in advance of the event and, with minimal publicity and disruption, seeks to sell the viable portions of the bank's business to healthy banks. An exemption from limits and delays ordinarily imposed on acquisitions by the anti-trust laws permits transactions involving failed banks to proceed immediately. Through the use of these tools, the FDIC is able in most cases to provide depositors at a failed bank with virtually uninterrupted access to the insured portion of their funds. Judicial review of the decision of the Federal Supervisor to place a bank in receivership is available; however, under U.S. law a litigant seeking to halt such a decision in advance of the Court's final decision bears a heavy burden.

\section{H. Main Findings}

\section{Objectives, independence, powers, transparency, and cooperation (CP 1)}

40. The multiplicity of agencies is a striking feature of the U.S. supervisory system. The assessors appreciate the benefits of constructive challenge and the checks and balances that a system with multiple parties can bring. While the assessors have not taken a view on the desirable number of regulators or the optimal regulatory structure for the U.S., it is clear that the system carries with it a heavy burden of ensuring cooperation and coordination between the agencies to avoid overlap and gaps. Sharing and confidentiality arrangements have been established to facilitate and improve information sharing between relevant agencies, but this remains somewhat of a patchwork. The assessment team saw many examples of opportunities for better inter-agency coordination and there remain gaps in consolidated oversight.

41. Another striking feature of the U.S. system is the general absence of detailed, clearly stated objectives and mandates for each agency in the agency's original governing statutes, which are common features of laws in some other countries. The assessment team observed redundancies in supervisory efforts, and a lack of clarity in the roles of each agency, which may be attributable, in part, to this absence of clear objectives 
and mandates. For example, FBAs are each separately ramping up their assessment of all entities in major banking groups, which typically include entities supervised by more than one FBA. The assessment team believes it is important for the authorities (defined to include the FBAs, departments responsible for policy, and legislators) to ensure clarity in the roles and expectations of each FBA. While coordination efforts exist, continued efforts are particularly important as mandates related to systemic stability are expanded and consumer protection mandates potentially altered. The core safety and soundness mandates and missions of the individual agencies need to be preserved. Otherwise, accountability will suffer.

42. In addition, the fundamental issue of interaction between the supervisory focus on the bank/thrift versus the holding company/group also needs to be addressed. The crisis showed one cannot be separated from the other. Collectively, the FBAs possess extensive powers of access, information gathering and examination, and their use is clearly evident. However, the Gramm-Leach-Bliley Act of 1999 (GLB Act) limits information gathering powers for individual agencies, which has an impact on the capacity of the FBAs to conduct full and effective consolidated supervision. The assessors noted that the U.S. Treasury proposes to remove some of these limitations as part of the financial regulation reform proposals.

43. The FBAs have a strong tradition of authority and accountability for supervisory matters being vested in those in charge of the supervision of individual banks and holding companies. This system has considerable strengths, but the crisis has revealed the need for agencies to better integrate institution-specific information and judgments about emerging risks with experience from broader (system-wide) perspectives. Improvement plans need to be inter-agency not just within each agency, which will require strong governance. In some FBAs, it is also desirable to ensure that risks and supervisory matters for major institutions get on-going regular attention at the highest levels.

Modifications in the internal governance and accountability structures and processes could also be improved to allow for better integration of field and headquarters views of risks, and strengthen the appropriateness and timeliness of supervisory responses.

\section{Licensing and structure (CPs 2-5)}

44. Somewhat unusually, banks have some degree of choice over their regulator. This is largely due to the existence of a dual banking structure-involving state and Federal charters - and multiple federal regulators. As noted in the U.S. Treasury White Paper on Financial Regulatory Reform (p.5), "fragmentation of supervisory responsibilities... allowed owners of banks...to shop for the regulator of their choice." The authorities have recently taken partial steps to reduce the possibility of improper charter conversion. Since inappropriate charter conversions undermine the credibility of the regulatory agencies, the implementation of the new rules, and - if needed - supplementary rules, should be closely monitored by the authorities to see whether they should be further strengthened. The assessors are aware that the actual number of conversions in each year is small, but there remains an "implicit threat" of conversion from banks to their supervisors. The stated minimum capital of US\$2 million for new banks is also relatively low, compared 
to many other countries; however, in practice much higher capital levels can be required for de-novo banks.

\section{Prudential regulation and requirements (CPs 6-18)}

45. The U.S. system is still on the Basel I risk-based capital framework, though the advanced approaches of Basel II have been enacted and will apply to the major banks over the next 2-3 years. Some additional features have been incorporated in the U.S. Basel I framework, e.g., an approach to securitization that is not present in Basel I. In addition, the U.S. capital regulations include minimum leverage ratio requirements. The BCPs require supervisors to set prudent and appropriate minimum capital adequacy requirements for banks. This is generally true in the United States and the U.S. system contains features such as the leverage requirements and Prompt Corrective Action requirements that lead banks to hold capital well above the minimum. However, some important shortcomings relative to $\mathrm{CP}$ 6 exist in the definition of Tier 1 capital for holding companies with regard to innovative instruments, in the absence of capital rules for SLHCs, and in allowing intangibles to count for a very high portion of a bank or thrift's Tier 1 capital. As the FBAs have pointed out, the "definition of capital" issues may also be present in other major jurisdictions, and this raises issues of competitive equity. Matters related to international consistency in the definition of capital and harmonization of deductions are currently being discussed internationally by the Basel Committee on Banking Supervision (BCBS).

46. Severe shortcomings in bank risk management have been revealed in the recent crisis and supervisory oversight was not effective in identifying those weaknesses and having them remedied. These shortcomings have been sufficiently large to create serious problems for both individual banks and for the financial system. While it would be unrealistic to expect a financial crisis of this magnitude not to have revealed weaknesses, the extent and seriousness of those weaknesses has been remarkable. As has been noted in reports issued by global senior supervisors, many of these were not unique to the U.S. However, given the systemic importance and complexity of the U.S. market, bank risk monitoring and management systems in the United States, and the U.S. authorities' ability to assess them, must be held to a very high standard.

\section{These weaknesses resulted partly from the confluence of credit (including} counterparty credit), market, and liquidity risk under extreme conditions. Multiple mergers in some institutions contributed to inconsistencies and weaknesses in enterprisewide risk architecture. There is general agreement that the banking system needed to be able to better identify, manage, and mitigate build-ups in risk. There is broad, shared understanding of the improvements needed and the strategy to achieve them, and the processes to monitor progress are already in place. While improvements in risk governance are needed, major risk monitoring improvements at banking organizations that involve complex Information Technology (IT) systems take time. Better relating compensation to risk is at an early stage of implementation. How robust the balance is between risk and reward has to be tested in more growth-oriented times. Challenges in addressing the shortcomings for banks and supervisors mean that necessary improvements may take some time to implement and will not be in place in the immediate term. Given this state of affairs, supervisors will need to consider what compensating measures, beyond those already in 
place, they may expect firms to maintain until risk management improvements are more fully embedded.

48. The FBAs have well-developed policies and processes to regulate and supervise traditional credit risk. However, there is clear evidence that in the recent turmoil and the events leading up to it, these processes were not fully effective for certain markets and products. Supervisors were ineffective in preventing a widespread and material decline in underwriting standards of residential mortgage loans. Material credit concentrations emerged (including in Commercial Real Estate (CRE) concentrations at smaller and mid-size banks) and were monitored, but action was not sufficient. Weaknesses also existed in the analysis (by banks and supervisors) of complex credit products, and stress testing at large and smaller banks (appropriate to their size and complexity) was insufficiently developed. Surveillance and monitoring of credit risk needs to be enhanced (not just in banks but also in their affiliates and others they deal with). This monitoring needs to be better linked to effective action, in advance, to reduce the breadth and severity of credit risk problems in a future credit cycle.

49. Linking monitoring to effective action will require a more comprehensive, shared, coordinated, and strategic approach to supervisory and regulatory enhancements than that presented to the assessors. The additional monitoring, supervisory focus, and credit risk measurement tools being developed by certain FBAs are all desirable enhancements, and would fit into such a strategy. However, a comprehensive approach for the future would be built on an understanding of why FBA processes did not consistently perform as desired in the recent past. A comprehensive approach would address issues such as the forcefulness of interventions, timeliness of guidance, revisiting whether guidance needs to occasionally contain specific limits to be effective, consistency of followup on new guidance, and the ability of the FBAs to intervene to make their views known in future about systemic weaknesses in credit risk management practices, but that may need to be addressed by the authorities more broadly.

50. The crisis has also revealed material weaknesses in market risk monitoring and management by financial institutions. The major issues are in the areas of suitability of certain market risk measurement and monitoring processes and models at certain major firms, lack of reliable and prudent valuation of mark-to-market (MTM) positions, and completeness and use of market stress testing. Despite the existence of rules, supervisory implementation has not been as effective as necessary. Substantive improvements are required and improvements are in progress. But in some cases, these will take considerable time (including supervisory time to verify robustness) particularly where material improvements in IT or risk architecture or risk culture are involved. Better relating compensation to risk adjusted return is particularly important, but hard to achieve. It will be important for banks and supervisors to confirm that the new processes operate effectively as planned, as more robust market conditions return.

51. FBA guidance on liquidity risk management and supervision is consistent with existing international standards and is likely to evolve in the near term due to pending interagency liquidity guidance and Basel liquidity standards. Market events during the crisis moved the FBAs to assess the overall effectiveness of the implementation of the 
supervisory processes used in enforcing such guidance. Liquidity monitoring was greatly expanded and contingency plans tested. Improvements are required to make sure these crisisdriven measures used in banks and by supervisors are incorporated into more structured and sustainable improved liquidity risk management practices by banks and enhanced ongoing liquidity risk assessment by supervisors. Further progress to achieve high-quality ongoing liquidity risk management is required at certain major complex banks. Again, the needed direction is well understood by FBAs. This includes the capability for timely stress testing closely linked to management decisions regarding P\&L and balance sheet positions. These improvements are linked to progress being made on better aggregation on an enterprise-wide basis of data and position information, on- and off-balance sheet, linked consistently in a timely manner to the banks' P\&L, financial, and balance sheet systems.

52. Supervision of operational risk appears to be effective overall, although some greater focus and specialization might be beneficial, perhaps learning from Basel II experience. Furthermore, operational risk is typically a group-wide risk which is not confined to individual legal entities or balance sheets (e.g., IT and accounting systems, physical security, disaster recovery, and business continuity planning). To gain a truly groupwide perspective on operational risk will take considerable coordination amongst the agencies. Examples of good work that is currently undertaken in this regard are the Federal Financial Institutions Examination Council (FFIEC)'s IT Subcommittee (ITS) (which has produced common examination and guidance material), and the MDPS, Regional Technology Service Provider (TSP) and Basel II operational risk supervisory processes (which involve interagency supervision activities).

53. Supervision of interest rate risk - an issue which is of increasing importance in the current environment - is broadly consistent across the FBAs in most material respects. Additional benefits could be obtained from improved consistency in examination approaches and measurement techniques. Ideally, there would be a common framework for Interest Rate Risk (IRR) measurement across all FBAs (notwithstanding that this common framework could still have variations to take account of the differences and complexities in measuring IRR in a large internationally-active bank versus a small community bank with a simple balance sheet). Such a framework could be used as a basis for better assessing and comparing individual banks and identifying outliers, and to improve the consistency of assessment and CAMELS ratings.

54. Banks maintain comprehensive programs, policies and procedures to reduce the risk of endangering the safety and soundness of the bank through abuse of its operations and services, including physical safety. Supervisors monitor effectively, in their full-scope or targeted examinations, which banks comply with their undertakings. Internal audit and internal controls also contribute to overall oversight. The requirements for reporting on suspicious transactions, for example, within the bank, to the supervisors, and to the relevant judicial authorities, appear adequate. However, the FATF assessment conducted in 2006 identified a number of deficiencies relevant to banks that need to be remedied. 


\section{Methods of ongoing banking supervision (CPs 19-21)}

55. The FBAs collectively have broad, but not unlimited, legal authority to regulate and supervise banks and holding companies subject to their jurisdiction. The FBAs use their authority to conduct on-site reviews and off-site analyses to develop a thorough understanding of the risk profile of banks and holding companies. The primary tool of supervision is the on-site examination, and the FBAs conduct full-scope on-site examinations of banks at least once every year or 18 months. For the largest banking organizations, supervisory activities are continuous, supported by on-site examination teams. Bank holding company inspection cycles are mandated depending upon size, complexity, and rating. SLHC examinations are conducted concurrently with the OTS examination of its subsidiary savings associations. During the period of time in between full-scope, on-site examinations, the FBAs use off-site surveillance to maintain their understanding of the bank's and holding company's risk profiles. All of these mechanisms are constrained to some extent when the individual agency is not the supervisor of the entire group, or part of the group is subject to the primary oversight of another functional regulator. There is a substantial continuous supervision program at major banks.

56. Individually, each of the FBAs employs standard supervisory techniques in a broadly consistent manner. Each agency supplies its supervisory staff with extensive manuals, guidance, and other assessment mechanisms which supervisors can use to develop their assessments and judgments. These appear well embedded in each agency's practices. There are, however, areas where the agencies could improve consistency between their operating processes, and seek to develop a "best of breed" model for supervision. There appear to be unnecessary differences in examination manuals, with each agency using supplementary assessments and rating systems designed to support the CAMELS framework, and different off-site surveillance models. The CAMELS-based rating system used by U.S. supervisors is somewhat outdated compared to those now used by overseas peers, and relies on high-level and fairly broad descriptions. The system also does not distinguish very well between inherent risk and risk controls, and guidance on assigning the component ratings also tends to overlap. Ratings also appear to be slow to adjust to developments (reflecting the annual cycle of review) and are "sticky" over time. The lack of risk differentiation provided by the ratings might possibly reflect adverse incentives created by the multiple uses to which ratings are put (e.g., ratings influence deposit insurance premiums, deposit-gathering capacity, and branching/acquisition approval requirements).

\section{The FBAs consider that the uniform CAMELS framework and their own} separate supplementary risk rating systems serve two distinct purposes, and when combined, provide more complete information than either would provide individually about the condition and evolution of the industry. However, it is not clear why this information cannot be captured in a single measure and, in any event, the supplementary risk rating systems differ by agency and are not readily comparable. The assessors recommend that either (i) the Uniform Financial Institutions Ratings System (UFIRS) be overhauled, building on the good work that has been done by individual agencies in developing their own more granular and risk-based rating systems, or (ii) if the FBAs consider the CAMELS system is too embedded in the broader regulatory system to be easily changed, greater effort 
be directed to developing a consistent, more granular, forward-looking risk rating system that at least provides a "common language" across the FBAs.

58. The recent market turmoil has highlighted important areas where regulatory oversight and coordination need to be strengthened. The general approach and structure of supervision has not assisted in developing and maintaining a thorough understanding of the operations of individual banking groups, and also of the banking system as a whole. The U.S. Treasury Department's financial reform package proposes to strengthen the capacity for consolidated oversight of financial groups, but the supervisory intensity of the non-banking parts of banking groups will also need to increase.

\section{Accounting and disclosure (CP 22)}

59. The U.S. agencies provide for extensive disclosure of financial information by regulated banks and holding companies. This disclosure is founded on U.S. GAAP. Both the FASB and the IASB are currently reviewing accounting standards with a view to (i) converging to a single set of standards, and (ii) considering the lessons learned from the recent financial crisis. Key developments will be the decisions taken on revised international standards for fair value accounting and loan loss provisions.

60. In discussions with supervisory staff, the decision to align regulatory reporting with U.S. GAAP, particularly with respect to the allowance for loan losses, was repeatedly criticized. Because U.S. GAAP applies an incurred loss model for loan loss allowances, which does not permit consideration of future events when estimating loan losses, examination staff of all agencies expressed frustration at the limitations on their ability to require banks to report what they considered to be appropriate loan loss reserves from a safety-and-soundness perspective. The assessors noted that the same outcome-larger buffers against loan losses-could be achieved by imposing higher minimum capital requirements if loan loss allowances measured in accordance with U.S. GAAP were not adequate to address supervisory concerns, but supervisory staff felt this was more difficult to implement and was better addressed by an 'above the line' charge to explicitly recognize the potential for future loan losses. The current framework also undermines the efficacy of the PCA regime, as the thresholds for regulatory intervention are aligned to U.S. GAAP reporting (the assessors noted numerous instances of 'well capitalized' banks being subject to regulatory sanctions for being insufficiently capitalized).

\section{Corrective and remedial powers of supervisors (CP 23)}

61. Generally, the FBAs identify problems during on-site and off-site examinations. Most issues are resolved informally during the examination (or in the ongoing discussions between the bank and the EIC/Central Point of Contact (CPC) where relevant), when the bank or holding company takes steps to address any regulatory concerns. Some problems, especially if serious, pervasive or repeated, may need to be addressed through formal supervisory action, which always is expressed in a written document from the supervisors. All formal supervisory actions are, at a minimum, published on a monthly basis (with limited exceptions). Detailed policies and action plans with specific target dates may be requested from a bank or holding company, and supervisors will review the institution's board's plan 
for sufficiency and examine written progress reports by the bank against key milestone dates. Progress is also assessed through ad hoc or normal on-site examinations.

62. The FBAs have a range of supervisory options when a bank or holding company is not complying with laws, regulations or supervisory decisions, or is engaging in unsafe and unsound practices. The agencies may take prompt remedial action and impose penalties. Remedial penalties and sanctions may be applied to banks and holding companies and, when appropriate, to management, board members, employees, controlling shareholders, other persons who participate in a bank's or holding company's affairs, and independent contractors, such as attorneys, appraisers, and accountants. The range of tools is applied in accordance with the gravity of the situation. If there are serious or repeated deficiencies, or when management has not acted sufficiently on an informal request, the agencies may take formal enforcement action. In cases where there is an immediate threat to the bank or holding company or to the depositors' interests, an agency may take immediate action by issuing a temporary order to cease and desist.

63. A PCA regime applies to those instances in which a bank's capital falls below the prescribed minimum ratios/levels. The regime provides a backstop against regulatory forbearance. The agencies also have powers to intervene even before the minimum capital ratio is breached. As an indicator of timely actions by the authorities, the rapid resolution of some major banks (and non-banks) during the present crisis can be noted. However, in many cases, while adhering to regulations and supervisory guidelines, supervisors will assess banks as being capital deficient and will require an infusion of capital, while at the same time the bank could be defined as "well capitalized" under the definitions of the PCA. This dichotomy arising from the relative inconsistency between the U.S. GAAP-based PCA regime and supervisory risk assessment systems could weaken the credibility of enforcement actions.

\section{Consolidated and cross-border banking supervision (CPs 24-25)}

64. The existing legislation for consolidated supervision needs to be strengthened. The Federal Reserve is responsible for consolidated supervision for U.S. BHCs, including FHCs. OTS is responsible for the consolidated supervision of savings and loan holding companies (SLHCs). All BHCs and SLHCs are subject to supervision on a consolidated basis. The Federal Reserve and the OTS are expected to rely, to the extent possible, on relevant primary supervisors and functional regulators for information about financial institutions within holding companies. As noted in the U.S. Treasury White Paper on Financial Regulatory Reform, "the GLB Act impedes the Federal Reserve's ability, as a consolidated supervisor, to obtain information from or impose prudential restrictions on subsidiaries of a BHC that already have a primary supervisor" (page 26). This is also true for the OTS with respect to SLHCs. Restrictions, both statutory and practical, on access to information on various parts of a group make it difficult to assess risks from a group-wide perspective. Some steps have been taken to overcome this drawback as a result of the crisis; specifically FBAs have ramped up their consolidated supervision efforts including for the former investment banks that are now BHCs. However, clear, ready, and direct access, legally supported, for whichever agency is responsible for consolidated supervision is desirable. The ability in the existing legislation for supervisors to get around these restrictions when there is "a material risk to the bank" is not workable. The legislative 
restrictions need to be repealed. The consolidated supervision regime would be improved if the currently de facto risk-based application and monitoring of large exposure and related party limits were to be explicitly mandated by regulation for holding companies. The supervisor monitors such holding company exposures using a risk-based approach, but that will not necessarily ensure sufficient robustness. Nor does the OTS apply formal consolidated capital requirements for SLHCs.

\section{The FBAs have clear authority to share confidential supervisory information} with foreign banking and other sector supervisors. This facilitates global consolidated supervision and implementation of the underlying home-host relationship framework, but it is subject to the limitation of not impinging on "U.S. interests". The information must be used for lawful supervisory purposes, and the recipients must keep the information confidential. FBAs provide adequate data and information to host country supervisors about U.S. banks and holding companies, to enable the host country to supervise the overseas operations of the U.S. banks. The FBAs have ongoing contact with supervisors in other countries in which U.S. banks or holding companies have material operations, including periodic visits to discuss supervisory issues.

\section{Table 1. Summary Compliance with the Basel Core Principles-Detailed Assessments}

\begin{tabular}{|c|c|l|}
\hline \multicolumn{1}{|c|}{ Core Principle } & Grading & \multicolumn{1}{|c|}{ Comments } \\
\hline $\begin{array}{l}\text { 1. Objectives, independence, powers, } \\
\text { transparency, and cooperation }\end{array}$ & C & $\begin{array}{l}\text { The authorities comply with this subcomponent } \\
\text { of CP 1. Agency mandates are derived from, but } \\
\text { are not always expressly stated in, legislation as } \\
\text { in some other countries. Greater clarity is needed } \\
\text { on the expectations of the bank supervisor and the } \\
\text { holding company supervisor where these are } \\
\text { different agencies to ensure strong coordination } \\
\text { and clear accountability for the supervision of } \\
\text { banking groups. Further clarity in mandates and } \\
\text { expectations would be desirable as FBAs are } \\
\text { expected in future to enhance their contribution to } \\
\text { financial stability more broadly. }\end{array}$ \\
\hline $\begin{array}{l}\text { 1.2 Independence, accountability and } \\
\text { transparency }\end{array}$ & C & $\begin{array}{l}\text { The authorities comply with this subcomponent } \\
\text { of CP 1. Opportunities exist to better link } \\
\text { strategic resource planning to more-forward- } \\
\text { looking measures of risk and future resource } \\
\text { demands. Improved collaboration will be needed } \\
\text { for FBAs to make improvements such as better } \\
\text { linking on-site, surveillance and macro staff, } \\
\text { within and across agencies. Federal Reserve } \\
\text { District Bank governance may not fully protect } \\
\text { from the potential of influence from industry (or } \\
\text { the perception thereof); it should be clearly noted } \\
\text { that, there was no evidence of this in practice. }\end{array}$ \\
\hline
\end{tabular}




\begin{tabular}{|c|c|c|}
\hline Core Principle & Grading & Comments \\
\hline 1.3 Legal framework & $\mathrm{C}$ & $\begin{array}{l}\text { The authorities comply with this subcomponent } \\
\text { of CP } 1 \text {. }\end{array}$ \\
\hline 1.4 Legal powers & $\mathrm{C}$ & $\begin{array}{l}\text { The authorities comply with this subcomponent } \\
\text { of CP } 1 \text {. }\end{array}$ \\
\hline 1.5 Legal protection & $\mathrm{C}$ & $\begin{array}{l}\text { The authorities comply with this subcomponent } \\
\text { of CP } 1 \text {. }\end{array}$ \\
\hline 1.6 Cooperation & $\mathrm{C}$ & $\begin{array}{l}\text { The authorities comply with this subcomponent } \\
\text { of CP } 1 \text {. There are channels for cooperation, } \\
\text { coordination, and leveraging off best } \\
\text { practices-within and between FBAs and } \\
\text { functional supervisors that could be further } \\
\text { enhanced as assessors saw many examples of } \\
\text { opportunities for better inter-agency coordination. }\end{array}$ \\
\hline 2. Permissible activities & $\mathrm{C}$ & The authorities comply with this $\mathrm{CP}$. \\
\hline 3. Licensing criteria & $\mathrm{C}$ & $\begin{array}{l}\text { The authorities comply with this CP. The scope } \\
\text { of the interagency agreement to prevent } \\
\text { inappropriate charter conversions should be } \\
\text { strengthened. } \\
\text { The (absolute) minimum capital requirement for } \\
\text { new banks is relatively low, although practice has } \\
\text { required higher levels of capital. }\end{array}$ \\
\hline 4. Transfer of significant ownership & $\mathrm{C}$ & The authorities comply with this CP. \\
\hline 5. Major acquisitions & $\mathrm{C}$ & The authorities comply with this $\mathrm{CP}$. \\
\hline 6. Capital adequacy & $\mathrm{LC}$ & $\begin{array}{l}\text { CP } 6 \text { requires supervisors to set prudent and } \\
\text { appropriate minimum capital adequacy } \\
\text { requirements for banks. This is generally true and } \\
\text { features such as Prompt Corrective Action and } \\
\text { leverage requirements lead banks to hold capital } \\
\text { well above the minimums. However, important } \\
\text { shortcomings exist in the definition of Tier } 1 \\
\text { capital for holding companies with regard to } \\
\text { innovative instruments, in the absence of capital } \\
\text { rules for SLHCs, and in allowing intangibles } \\
\text { (especially mortgage servicing rights) to count for } \\
\text { a very high portion of a bank or thrift's Tier } 1 \\
\text { capital. }\end{array}$ \\
\hline
\end{tabular}




\begin{tabular}{|c|c|c|}
\hline Core Principle & Grading & Comments \\
\hline 7. Risk management process & $\mathrm{MNC}$ & $\begin{array}{l}\text { Despite the existence of formal rules, severe } \\
\text { shortcomings in enterprise-wide risk monitoring } \\
\text { and management at banks, were revealed in the } \\
\text { recent crisis. Supervisory oversight was not } \\
\text { effective in identifying those weaknesses and } \\
\text { having them remediated. They created serious } \\
\text { problems for banks and for the financial system. } \\
\text { Although many of these weaknesses were present } \\
\text { in other firms in other jurisdictions, because the } \\
\text { U.S. system will likely remain at the forefront of } \\
\text { financial innovation, it is imperative that risk } \\
\text { monitoring and management systems be } \\
\text { compliant with the requirements of this principle, } \\
\text { which are high for the U.S., considering (as the } \\
\text { CP mandates) the size and complexity of the } \\
\text { financial sector. Although weaknesses have been } \\
\text { partially remedied the robustness of needed } \\
\text { improvements-in both banks and supervisors- } \\
\text { will take some time to implement and test. }\end{array}$ \\
\hline 8. Credit risk & $\mathrm{LC}$ & $\begin{array}{l}\text { There are well-developed rules and guidance, but } \\
\text { processes have not been fully effective for some } \\
\text { markets, particularly residential mortgages and } \\
\text { CRE exposures at smaller and mid-size banks. } \\
\text { Weaknesses in understanding risks of complex } \\
\text { credit products were not adequately remediated } \\
\text { by the supervisory process. Additional } \\
\text { monitoring, supervisory focus and credit risk } \\
\text { measurement tools being developed by certain } \\
\text { FBAs are all desirable enhancements, but need to } \\
\text { be placed in a more comprehensive, coordinated } \\
\text { strategy designed to deal with identified } \\
\text { weaknesses (including timliness of guidance, } \\
\text { intervention and will to act) and position the U.S. } \\
\text { to better deal with future credit cycle issues well } \\
\text { in advance of them becoming serious problems. }\end{array}$ \\
\hline 9. Problem assets, provisions, and reserves & $\mathrm{C}$ & $\begin{array}{l}\text { The authorities comply with this CP. The FBAs } \\
\text { process is well developed and effective. Its } \\
\text { effectiveness would be increased if accounting } \\
\text { rules were changed to allow more-forward- } \\
\text { looking provisioning. }\end{array}$ \\
\hline 10. Large exposure limits & $\mathrm{C}$ & $\begin{array}{l}\text { The authorities comply with this CP. although the } \\
\text { aggregate regulatory limits for total large } \\
\text { exposures (loans plus other exposures) are high, } \\
\text { in comparison with international practices. } \\
\text { Reporting requirements on large exposures lack } \\
\text { some detail (e.g., not showing total indebtedness) }\end{array}$ \\
\hline
\end{tabular}




\begin{tabular}{|c|c|c|}
\hline Core Principle & Grading & Comments \\
\hline 11. Exposure to related parties & $\mathrm{C}$ & $\begin{array}{l}\text { The authorities comply with this CP. However, } \\
\text { there is inadequate specificity in the supervisory } \\
\text { regulations on board oversight and involvement, } \\
\text { and the reporting requirements to boards and to } \\
\text { the supervisors lack in scope and detail. These } \\
\text { weaknesses are compensated for to a high degree } \\
\text { by supervisory policies and reviews, which } \\
\text { expect active board oversight and monitoring of } \\
\text { related lending, and require remedial action in } \\
\text { case deficiencies are observed. The limit for } \\
\text { aggregate lending to a single related party or to a } \\
\text { conntected group of related parties is set at } 15 \\
\text { percent of the bank's own fund plus surplus funds } \\
\text { (i.e., excess provisions for loan losses) which is } \\
\text { in accordance with international best practices. } \\
\text { The overall limit for lending to all related parties } \\
\text { in aggregate is set at } 100 \text { percent of own funds } \\
\text { plus surplus funds, which is higher than } \\
\text { international practice, although the supervisory } \\
\text { policy includes the possibility to comment on } \\
\text { exposures even within the limit, if deemed unsafe } \\
\text { or unsound }\end{array}$ \\
\hline 12. Country and transfer risks & $\mathrm{C}$ & The authorities comply with this $\mathrm{CP}$. \\
\hline 13. Market risks & $\mathrm{LC}$ & $\begin{array}{l}\text { Material weaknesses have been revealed at banks } \\
\text { in market risk monitoring, use of models, } \\
\text { valuation and risk management. Substantial } \\
\text { improvements are in progress, but will take time } \\
\text { to put in place and assess, because they entail } \\
\text { complex IT and risk architecture changes as well } \\
\text { as changes in governance, oversight and } \\
\text { compensation incentives. }\end{array}$ \\
\hline 14. Liquidity risk & $\mathrm{LC}$ & $\begin{array}{l}\text { Guidance on liquidity risk management and } \\
\text { supervision is consistent with existing } \\
\text { international standards (although likely will } \\
\text { evolve in the near term in accord with } \\
\text { international efforts). Needed improvements to } \\
\text { effectiveness are in progress at banks and } \\
\text { supervisors, but cannot be fully assessed } \\
\text { currently. Crisis-induced focus on liquidity at } \\
\text { banks and supervisors is being formalized into an } \\
\text { enhanced, regular, in-depth supervisory program. }\end{array}$ \\
\hline 15. Operational risk & $\mathrm{C}$ & $\begin{array}{l}\text { The authorities comply with this CP. The } \\
\text { agencies should continue to build more holistic } \\
\text { and structured approaches to operational risk } \\
\text { assessment, utilizing enhanced cross-agency } \\
\text { mechanisms. }\end{array}$ \\
\hline 16. Interest rate risk in the banking book & $\mathrm{C}$ & $\begin{array}{l}\text { The authorities comply with this CP. Supervisors } \\
\text { could consider introducing a consistent } \\
\text { measurement approach to improve risk } \\
\text { assessment across FBAs. }\end{array}$ \\
\hline
\end{tabular}




\begin{tabular}{|c|c|c|}
\hline Core Principle & Grading & Comments \\
\hline 17. Internal control and audit & $\mathrm{C}$ & The authorities comply with this CP. \\
\hline 18. Abuse of financial services & $\mathrm{C}$ & $\begin{array}{l}\text { The authorities comply with this CP. It is noted } \\
\text { that a number of CP } 18 \text {-relevant issues as } \\
\text { identified by the FATF remain to be addressed. }\end{array}$ \\
\hline 19. Supervisory approach & $\mathrm{LC}$ & $\begin{array}{l}\text { Authorities need to improve their approach to the } \\
\text { group-wide oversight of financial groups, } \\
\text { including unregulated entities. Introducing } \\
\text { domestic "supervisory colleges" involving all } \\
\text { material U.S. regulators for a group may assist, } \\
\text { although broader reform is necessary. A review } \\
\text { of risk rating systems, with a view to improving } \\
\text { their capacity to distinguish between banks, is } \\
\text { needed. }\end{array}$ \\
\hline 20. Supervisory techniques & $\mathrm{C}$ & $\begin{array}{l}\text { The authorities comply with this CP. It is } \\
\text { suggested that the authorities could review, } \\
\text { perhaps under the auspices of the FFIEC, existing } \\
\text { supervisory manuals and processes to remove } \\
\text { unnecessary differences and develop a "best of } \\
\text { breed" approach. }\end{array}$ \\
\hline 21. Supervisory reporting & $\mathrm{C}$ & $\begin{array}{l}\text { The authorities comply with this CP. It is } \\
\text { suggested that the authorities review solo } \\
\text { reporting requirements and consider the } \\
\text { implications of U.S. GAAP for the effectiveness } \\
\text { of supervision and the PCA regime. }\end{array}$ \\
\hline 22. Accounting and disclosure & $\mathrm{C}$ & $\begin{array}{l}\text { The authorities comply with this } \mathrm{CP} \text {, but could } \\
\text { consider the introduction of statutory reporting } \\
\text { ("whistleblower") obligations for external } \\
\text { auditors reporting to bank supervisors, along with } \\
\text { associated protections. }\end{array}$ \\
\hline $\begin{array}{l}\text { 23. Corrective and remedial powers of } \\
\text { supervisors }\end{array}$ & $\mathrm{C}$ & The authorities comply with this CP. \\
\hline 24. Consolidated supervision & $\mathrm{LC}$ & $\begin{array}{l}\text { Present legislation and practices hinder effective } \\
\text { conduct of consolidated supervision of financial } \\
\text { groups although supervisors work around this by } \\
\text { changing their interpretation of the GLB Act. } \\
\text { There are gaps in regulatory limits and reporting } \\
\text { of large exposures, related lending, and capital on } \\
\text { a consolidated basis at the holding company } \\
\text { level. De facto practices of applying and } \\
\text { monitoring large exposure and related lending } \\
\text { limits should be expressly mandated. Lacking a } \\
\text { fixed rule, SLHC capital is supervised on a case- } \\
\text { by-case basis. }\end{array}$ \\
\hline 25. Home-host relationships & $\mathrm{C}$ & The authorities comply with this CP. \\
\hline
\end{tabular}




\section{Table 2. Detailed Assessment of Compliance with the Basel Core Principles}

\begin{tabular}{|c|c|}
\hline Principle 1. & $\begin{array}{l}\text { Objectives, autonomy, powers, and resources. An effective system of banking supervision will } \\
\text { have clear responsibilities and objectives for each authority involved in the supervision of banks. } \\
\text { Each such authority should possess operational independence, transparent processes, sound } \\
\text { governance and adequate resources, and be accountable for the discharge of its duties. A suitable } \\
\text { legal framework for banking supervision is also necessary, including provisions relating to } \\
\text { authorization of banking establishments and their ongoing supervision; powers to address } \\
\text { compliance with laws as well as safety and soundness concerns; and legal protection for } \\
\text { supervisors. Arrangements for sharing information between supervisors and protecting the } \\
\text { confidentiality of such information should be in place. }\end{array}$ \\
\hline Description & $\begin{array}{l}\text { The current framework for the regulation and supervision of financial institutions in the United } \\
\text { States has developed over many decades primarily in response to a series of financial crises and } \\
\text { other important social, economic, and political events. The structure of the financial system } \\
\text { necessitates a high degree of coordination among all relevant supervisors (both federal and, } \\
\text { where applicable, state), both in formulating regulatory and supervisory standards and } \\
\text { supervising individual banks and holding companies. } \\
\text { The United States operates under a "dual banking system." A bank may choose to be chartered } \\
\text { by the federal government or by a state. Federal bank charters for "national banks" are issued by } \\
\text { the OCC. The OTS issues charters for "federal savings associations." Each of the } 50 \text { states has a } \\
\text { banking authority that charters banks under its own laws and regulations. These banks are } \\
\text { generally referred to as "state banks" or "state savings associations" (in this BCP, assessment the } \\
\text { words "thrift" and "savings association" are used interchangeably). There can be differences in } \\
\text { powers and corporate governance requirements, business powers and other rules applying to } \\
\text { state-chartered banks and federally chartered banks depending on the chartering authority. } \\
\text { Each U.S. bank, whether chartered under state or federal law, is subject to regulation, } \\
\text { supervision, and examination by a primary FBA, irrespective of whether the bank is part of a } \\
\text { broader organization: } \\
\text { - for national banks, this is the OCC; } \\
\text { - for state banks that choose to be members of the Federal Reserve System (state member } \\
\text { banks), this is the Federal Reserve; } \\
\text { - for state banks that choose not to become members of the Federal Reserve System } \\
\text { (nonmember banks) this is the FDIC; and } \\
\text { for federal or state savings associations, this is the OTS. } \\
\text { The FBAs generally have responsibility for regulating and supervising banks under their } \\
\text { jurisdiction. In addition, the Federal Reserve and the OTS have the responsibility for regulating } \\
\text { and supervising bank and thrift holding companies (BHCs, SLHCs,) respectively. }\end{array}$ \\
\hline & Compliant \\
\hline \multicolumn{2}{|l|}{ Comments } \\
\hline Principle 1(1). & $\begin{array}{l}\text { Responsibilities and objectives. An effective system of banking supervision will have clear } \\
\text { responsibilities and objectives for each authority involved in the supervision of banks. }\end{array}$ \\
\hline Description & $\begin{array}{l}\text { EC 1: Each FBA operates pursuant to an express statutory grant of authority. In addition, agencies } \\
\text { are mandated to administer various specific statutes which contain implicit or explicit goals (e.g., } \\
\text { related to fair lending, community reinvestment, bank secrecy, and anti-money laundering/counter } \\
\text { terrorist financing,). The FBAs also exercise competition authority powers with respect to bank } \\
\text { mergers, using Justice Department criteria. Legislation creating the agencies does not contain } \\
\text { explicit and clear statements of mission or mandate. However, the substantive requirements } \\
\text { imposed on agencies by statute provide the basis for the agencies' publicly reported and }\end{array}$ \\
\hline
\end{tabular}


longstanding, defined objectives and responsibilities. These typically include promoting safety and soundness, maintaining financial stability, effective competition, and providing fair access to financial services and fair treatment of customers.

The FDIC also has an additional objective of minimizing the disruptive effects that can occur within the banking system when banks or savings associations fail. The OTS has the additional objective of encouraging savings associations to provide credit for housing safely and soundly.

Discussions with various agency heads indicated that they appreciate the potential conflicts in these objectives but have been able to balance these objectives in their planning and resource allocation to ensure that safety and soundness objectives are not compromised. Several others the assessors talked to noted the swings in agencies' focus on their various mandates which occur in response to events and to public reaction and congressional oversight.

Legislation proposed by the U.S. administration and Congress includes alteration in agency responsibilities for consumer protection. The administration's legislative proposal also includes the agency heads in the financial services oversight council (chaired by Treasury), related to financial stability more broadly. It is designed to facilitate coordination of policy development, rulemaking, examinations, reporting requirements, and enforcement actions. It is also to provide a forum for discussion of emerging market developments and financial regulatory issues, and for resolution of jurisdictional disputes.

EC 2: Under the existing legislation, agencies have delegated authority for rulemaking and also issue guidance and manuals that describe supervisory expectations. Taken together, the banking statutes, regulations, guidelines, policy statements, interpretations, and supervisory guidance and manuals establish a framework of minimum prudential standards and best practices that banks and holding companies must meet. They address such matters as capital adequacy, loan underwriting, single borrower and related party exposure limits, asset quality, loan losses and provisioning, risk management (including requirements for addressing specific types of risks), internal controls and audits, accounting standards, liquidity, Anti-Money Laundering and Combating the Financing of Terrorism (AML/CFT)/anti-fraud measures, among others.

In addition, various laws deal with the relationship among regulators in meeting their mandates. For example, the Gramm Leach Bliley Act (GLB) covers the requirement for umbrella holding company supervisors to rely as much as possible on the bank examinations conducted by the primary functional supervisor. Within a banking group, the Federal Reserve, for instance, as holding company supervisor relies on the functional regulators of any securities and insurance subsidiaries for supervisory information. The primary federal banking or holding company supervisor can only conduct an examination of a functionally regulated subsidiary, such as a securities firm, if the subsidiary is engaging in activities that pose a material risk to the bank, or for other prudential reasons and the information cannot be obtained from the functional regulator. As described in CP 24, during the crisis the practice has evolved, at least temporarily, to attempt to get around these restrictions.

In addition, separate legislation created the FFIEC, with the four FBAs on the board, together with voting representatives of State banking regulators, and the National Credit Union Association. The mandate from Congress to the FFIEC is to provide uniform principles, standards and report forms for the federal examination of financial institutions. Further discussion on the role of the FFIEC is contained in CP 20.

The FDI Act gives the FDIC back-up supervisory power for national banks and state members banks that are members of the Federal Reserve system, as well as for savings institutions regulated by the Office of Thrift Supervision. Legislation also establishes certain coordination mechanisms such as that for the FFIEC which are part of the overall framework.

Unlike banks, certain insured depositary institutions such as industrial loan companies (ILCs), 


\begin{tabular}{|c|c|}
\hline & 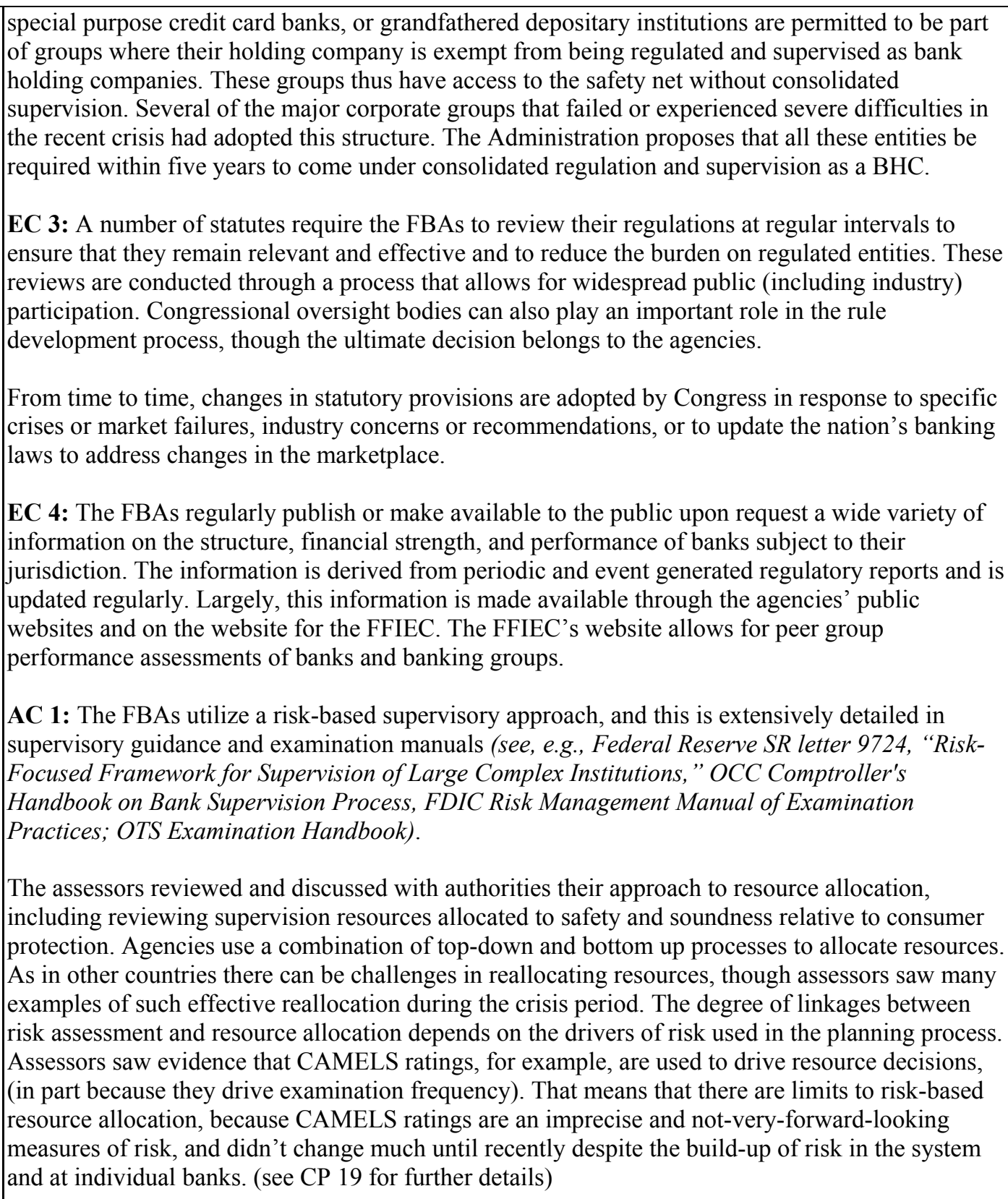 \\
\hline Assessment & Compliant \\
\hline Comments & $\begin{array}{l}\text { The assessors were struck by the multiplicity of mandates of the agencies. Their safety and } \\
\text { soundness mandate is clear. Though the CP does not require it, best practice internationally would } \\
\text { have all mandates set out in legislations, and more clarity on FBAs' expectations of what those } \\
\text { mandates mean in practice. In response to the crisis, all agencies are ramping up their roles in } \\
\text { supervision of both banks and holding companies that they are involved in. There is a risk that the } \\
\text { agencies will find less clarity of roles, and more potential for conflict and overlap, as they each } \\
\text { enhance their supervision of complex groups in the name of institutional safety and soundness and } \\
\text { financial stability. Experience elsewhere suggests that true accountability requires clarity of } \\
\text { mandate. } \\
\text { The fundamental issue of focus on the bank/thrift versus on the holding company/ group also needs } \\
\text { to be addressed. The crisis revealed that, for major groups, it proved impossible to wall off the } \\
\text { banks from risks posed by holding companies and/or other affiliates (which is inherent in the safety }\end{array}$ \\
\hline
\end{tabular}




\begin{tabular}{|c|c|}
\hline & 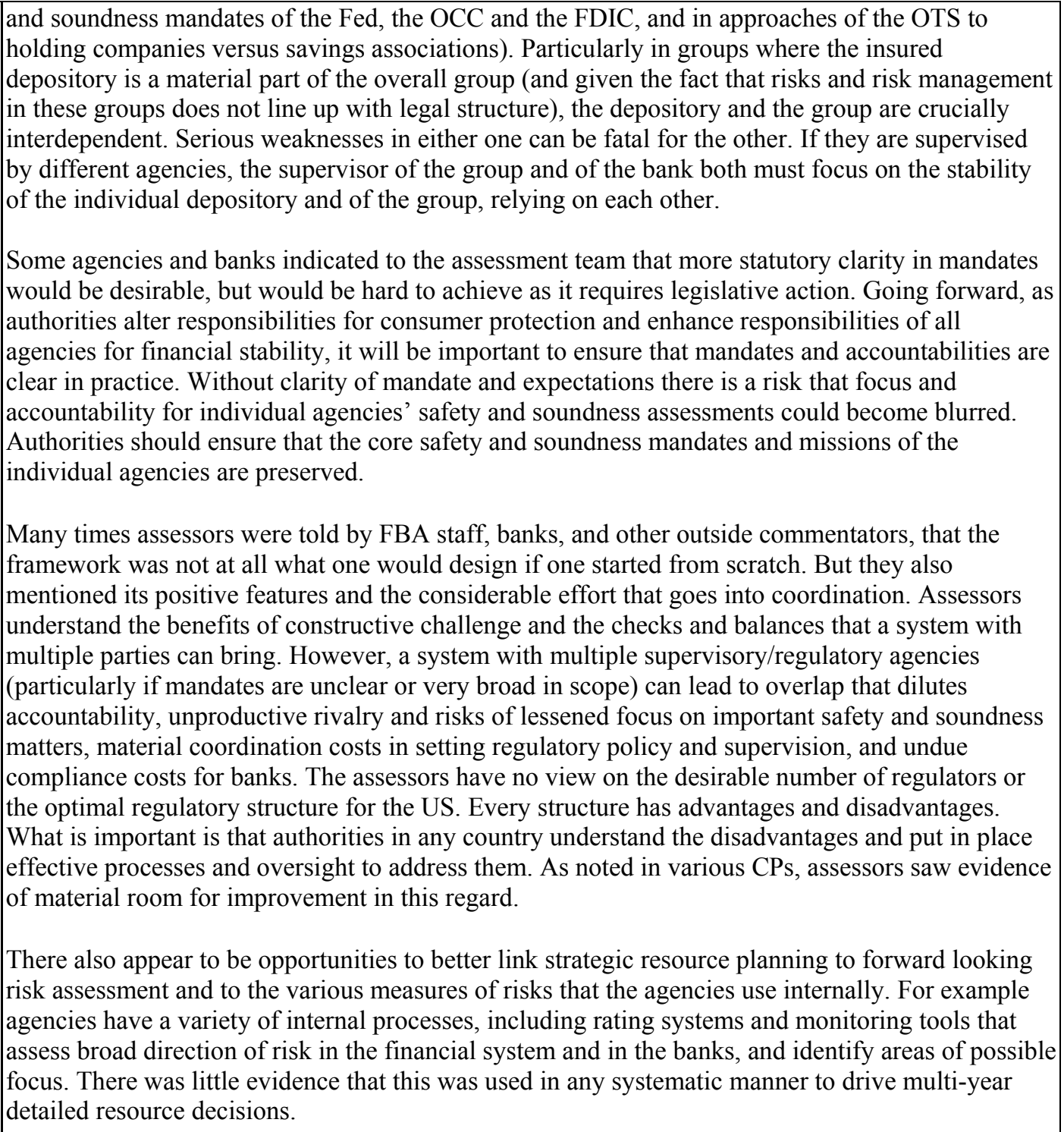 \\
\hline Principle 1(2). & $\begin{array}{l}\text { Independence, accountability and transparency. Each such authority should possess operational } \\
\text { independence, transparent processes, sound governance and adequate resources, and be } \\
\text { accountable for the discharge of its duties. }\end{array}$ \\
\hline Description & $\begin{array}{l}\text { EC 1: Laws set out the governance structure for the agencies. The OCC and OTS are separate } \\
\text { bureaus or offices reporting to the Secretary of the Treasury with provisions to protect their } \\
\text { independence from Treasury (e.g., by law the Secretary may not intervene in matters before the } \\
\text { agencies and may not delay or prevent issuance of any regulation.) The FDIC is an independent } \\
\text { agency with a board composed of three internal directors, appointed by the president with the } \\
\text { advice and consent of the Senate, and the heads of the OCC and OTS. The Federal Reserve is the } \\
\text { independent central bank with the Federal Reserve Board (FRB) and Reserve Banks. Reserve } \\
\text { banks are separate entities within the system with boards of directors, presidents and delegated } \\
\text { authority from the FRB for supervision. } \\
\text { Laws setting up the agencies specify the appointment process for the heads of the agencies, } \\
\text { (including Senate confirmation), which is for a fixed term. Heads may only be removed for cause, } \\
\text { and that the reasons for such removal must be laid before the Senate. Each of the agencies is } \\
\text { funded outside of the congressional appropriation process. The OCC and OTS are funded by fees } \\
\text { levied on banks determined by the agency without involvement of Treasury. The FDIC supervision }\end{array}$ \\
\hline
\end{tabular}


and regulation program is funded from interest earnings on the deposit insurance fund and the FRB supervision and regulation program is funded from income on the FRB's other operations as a central bank.

Agencies reported that they have operational independence in reaching safety and soundness decisions and the assessors saw or heard no evidence to the contrary.

Each of the agencies has a unique internal accountability structure for supervision and regulation involving authority and review at various regional or central levels. Within each agency there are processes for delegation of various supervision and regulation functions. For example, within the Fed system, Reserve Bank Presidents have delegated authority for supervisory matters from the board. In each organization, considerable day-to-day authority for supervision decisions (such as ratings of institutions) is vested in the examiner-in-charge (EIC) for each bank. Each agency has review processes that can result in changes in these assessments in exceptional cases. The structure of the various agencies leads to their own internal review and coordination processes which differ somewhat from agency to agency. There are also processes to allow banks to appeal formal decisions of the FBAs including ratings and proposed enforcement actions. The differences in internal structure between FBAs can add to inter-agency coordination challenges. Assessors were not able to conclude that these structural differences result in material differences in supervisory processes or outcomes, though the potential undoubtedly exists (see also CP 20).

Several agencies have made improvements in these internal accountability and governance arrangements in response to the crisis and to lessons learned. In some cases agencies have determined that improvements are needed in internal governance processes but the nature of these is being determined or has not been fully implemented. Often the changes being contemplated involve more centralized direction, coordination and oversight.

EC 2: Each of the FBAs complies with the Government Performance and Results Act of 1993, which requires federal agencies, in consultation with Congress and outside stakeholders, to prepare a strategic plan covering a multiyear period and submit an annual performance plan and performance report. The performance plans and assessments are incorporated into the agencies' annual reports, which are required to be made public. The agencies also are required, by separate statute, to report annually on regulatory and supervisory actions taken during the year.

There is considerable variation in the agencies' approach to public performance reporting for their regulation and supervision responsibilities, with differences in how goals are specified, measured and reported on, and considerable differences in the degree of focus on measures of activity versus outcomes. The agencies' performance reports related to regulation and supervision tend to specify a few performance measures, with a number of these related to completion of examinations within mandated cycles. There are also differences between agencies in the degree to which safety and soundness goals are reported separately from consumer protection goals.

As part of its governance, each agency has internal quality control processes for supervision - and conducts 'lessons learned' exercises. Each FBA also has an independent Inspector General that performs audits and evaluations of their operations. Having such functions is a best practice. As part of their mandate they are required by legislation to perform material loss reviews (which are published) of any bank failure that costs the FDIC insurance fund more than US\$25 million-a threshold that was set some time ago. These agencies are increasing their resources devoted to these mandated reviews, sometimes at the expense of other useful audit activities.

IGs the assessors met indicated that they have plans to step back from the individual reviews to see if there were themes such as insufficient forcefulness or timeliness of action that needed to be addressed by FBAs. As well, IGs indicated that they wished to enhance their reviews of the supervision processes but in some cases had not done many of such reviews over the past few years because of other priorities or resource constraints. 
reports.

Oversight and accountability to Congress occur through various statutory reporting and frequent extensive hearings on various financial regulatory issues. Agencies' independence in expressing their views to Congress in testimony is specified by law. On behalf of Congress, the Government Accounting Office (GAO) conducts and publishes audits of the agencies performance. In 2009, the GAO placed the financial regulatory structure on its 'high risk' list of matters warranting attention by Congress and the Executive branch of government. This was because of the GAO's view that significant market developments that, in recent decades, have outpaced a fragmented and outdated regulatory structure and significant reforms to the U.S. regulatory system are critically and urgently needed. The current regulatory approach was reviewed by the GAO as having significant weaknesses that if not addressed will continue to expose the U.S. financial system to serious risks.

EC 3: The FBAs specify that agency heads and all staff maintain high professional standards and exhibit high integrity. There are Federal laws and regulations, as well as individual conflict-ofinterest rules and codes of conduct applying to each of the federal banking agencies.

For all of the agencies, there are specific statutes governing ethical conduct. For example, the Comptroller of the Currency, the OTS Director, and the Federal Reserve staff are subject to statutory restrictions on activities and affiliations that might raise conflicts of interests. See, e.g., 12 U.S.C. $\$ \oint 27$ (unlawful for the Comptroller to hold an interest in a national bank), 242, 1462a(d) (unlawful for Director to hold an interest in an insured depository institution), 244 (respectively prohibiting Federal Reserve members from holding office in or stock of a member bank or related entities). Similarly, FDIC employees and examiners and certain other employees of OCC and OTS are prohibited from owning stock in any entity regulated by their agency. 5 CFR 3101.109 (OTS). In addition, members of the FDIC Board of Directors are prohibited from holding any office, position, or employment in any bank or holding company during their time in office and for two years after they leave office, subject to certain exceptions.

Senior examination staff of the FBAs generally are subject to a one year post-employment "cooling off" period with respect to entities they supervised. Violators are subject to civil monetary penalties, can be removed from office, and can be prohibited from participating in the affairs of the bank, the holding company, or any other company for up to five years. Examiners also are prohibited from accepting loans or gratuities from banks that they examine. See 18 USC $\S 213$. These standards are reinforced by a number of criminal statutes, including those prohibiting corruption, bribery, theft, and fraud by agency employees. These laws are actively enforced. Each agency has administrative policies to ensure that appropriate codes of conduct are being followed.

Banks and banking organizations assessors met indicated that, as a general matter, agency personnel operate with integrity and professionalism.

EC 4: Agencies have large numbers of examination staff. The FDIC is beefing up its staff at major banks. For larger banks and holding companies, each agency has on-site teams that are housed fulltime in the institution. These can range from 10-20 at a holding company to 50-70 at a major bank (the total can go as high as 80-90 once the teams from the various agencies are added together).

This is because of the emphasis they put on continuous supervision. These teams are supplemented with risk specialists who participate with the teams in various on-site reviews and themselves conduct and lead horizontal reviews. Headquarters or regional staff are involved in monitoring and surveillance, as well as policy and approvals work.

For mid-size institutions the examination team would be smaller but still have a dedicated EIC. For smaller banks, savings associations or community banks a portfolio approach is used. One EIC might be responsible for several smaller banks, with part-time support from other resources for specific examinations.

Assessors met with staff of the FBAs involved in budgeting and resource allocation and reviewed 
high level documents on these matters. Resource plans are done for the current year and one year forward (though published strategic plans cover a longer time period). The assessors focused on high-level understanding of the drivers of supervision resources allocated to large and small/medium-size banks. They also had the opportunity to discuss training plans (including with the FFIEC who runs training programs). In each of the agencies, overall resource levels related to supervision and regulation were essentially static in the 2-3 years prior to this assessment. In part, this appears to have been related to the fact that the number of 'problem banks' (CAMELS rated $4 / 5$ ) was also very low and static. Ongoing consolidation in the industry was also a factor. Starting in 2007/2008 there were modest FTE increases in agencies, which have accelerated more recently. Agencies also noted they were able to free up resources in their large bank groups because of mergers. The FTE increases are largest at the FDIC as resources are added for resolution for problem banks.

During the crisis some examinations and horizontal reviews were deferred. Some FBAs did not yet have a forward-looking resource plan related to new initiatives or improvements in supervision and monitoring processes and new priorities (e.g., more in-depth horizontal reviews, new priorities such as compensation reviews) that came from lessons learned from the crisis.

Each agency is also adding specialist resources. Agencies have some flexibility in pay structures and are benefiting from the current market environment to attract specialists with considerable industry experience.

The FBAs reported to the assessors that they have adequate resources to attract and retain sufficient numbers of qualified staff, with skills commensurate with the size and complexity of the institutions supervised. The mission reviewed material agencies use to monitor indicators of their human resources. The mission also discussed the state of market competition for resources, which has reduced because of the crisis. The major risk for some of the agencies is that around one-third of supervisory staff is eligible for retirement already or in the next five years.

Each of the agencies undertakes an internal evaluation process to ensure its staff meets its supervisory needs. Examples include annual skills gaps analysis to determine if staffs available are meeting critical supervisory needs. Hiring and retention programs are in place to attract and retain staffs that have critical and highly marketable skills. Existing efforts that the agencies have in place are variable-pay and retention programs, benchmarking, and bonus programs. The assessors discussed the strategies the agencies have to address the risks of loss of staff through retirements.

The salary scales, benefits, and work-life programs of the FBAs are not based on the U.S. Federal Government standards and provide more generous compensation. This provides greater flexibility to attract and retain qualified staff at each respective agency. Each FBA has a slightly different salary structure, and these salary scales or compensation packages are made available to the public.

The agencies have the ability to commission outside experts or consultants when and where needed to fulfill any supervisory gaps, particularly during periods of financial stress. Often these are former commissioned examiners who have retired that have familiarity with the agencies' procedures, processes, and objectives.

The agencies insist that staff undergo adequate and relevant training and ensure that sufficient resources are available for this purpose. Broadly, the FBAs have two developmental objectives: to train field examination staff to become commissioned examiners and to accomplish continuing professional development for existing commissioned examiners and other staff. The agencies use a combination of internal, external, and shared training programs to achieve these objectives; examples of shared training programs include collaboration through the FFIEC to provide continuing professional development courses on specialized topics. The agencies approve annual training budgets that provide employees with training opportunities each year. The FBAs participate in training offered by the FFIEC and by certain other regulatory agencies. All agencies are involved in developing and implementing basic and advanced training in relation to various 


\begin{tabular}{|c|c|}
\hline & $\begin{array}{l}\text { emerging issues as well as in specialized areas such as international banking, information } \\
\text { technology, anti-money laundering, capital markets, payment systems risk, and consumer } \\
\text { compliance. The FBAs require a staff member seeking an examiner's commission to take } \\
\text { proficiency exams or commissioning tests. } \\
\text { The agencies' supervisory staff have sophisticated technological equipment and support tools to } \\
\text { review the banking industry and assess individual banks and banking groups. The agencies are } \\
\text { heavily invested in electronic processes and each have an Information Technology office. FBAs } \\
\text { include travel as part of the cost of supervisory work and approve travel budgets annually. Travel } \\
\text { abroad is allowed and used to supervise the foreign operations of material U.S. banks and holding } \\
\text { companies and to participate in other international activities. } \\
\text { AC1: The heads of the FBAs are appointed by the President with the advice and consent of the } \\
\text { Senate to a set term in office. The heads of the OCC and the OTS are appointed to a five-year term. } \\
\text { During their tenure they also serve as directors of the FDIC. The FDIC's three remaining directors } \\
\text { are appointed to six-year terms, although one of the appointed members is designated as Chairman } \\
\text { for a five-year term. Members of the Federal Reserve Board of Governors are appointed to a full or } \\
\text { to an unexpired portion of a 14-year term. On appointment by the President and with the advice } \\
\text { and consent of the Senate, one of the members is designated to serve as Federal Reserve Chairman, } \\
\text { and another of the members is designed to serve as Vice Chairman, for a four-year term. } \\
\text { All of these agency positions are non-partisan, and there is no expectation that agency heads will } \\
\text { resign at the conclusion of the term of the President who appointed them. }\end{array}$ \\
\hline Assessment & Compliant \\
\hline Comments & 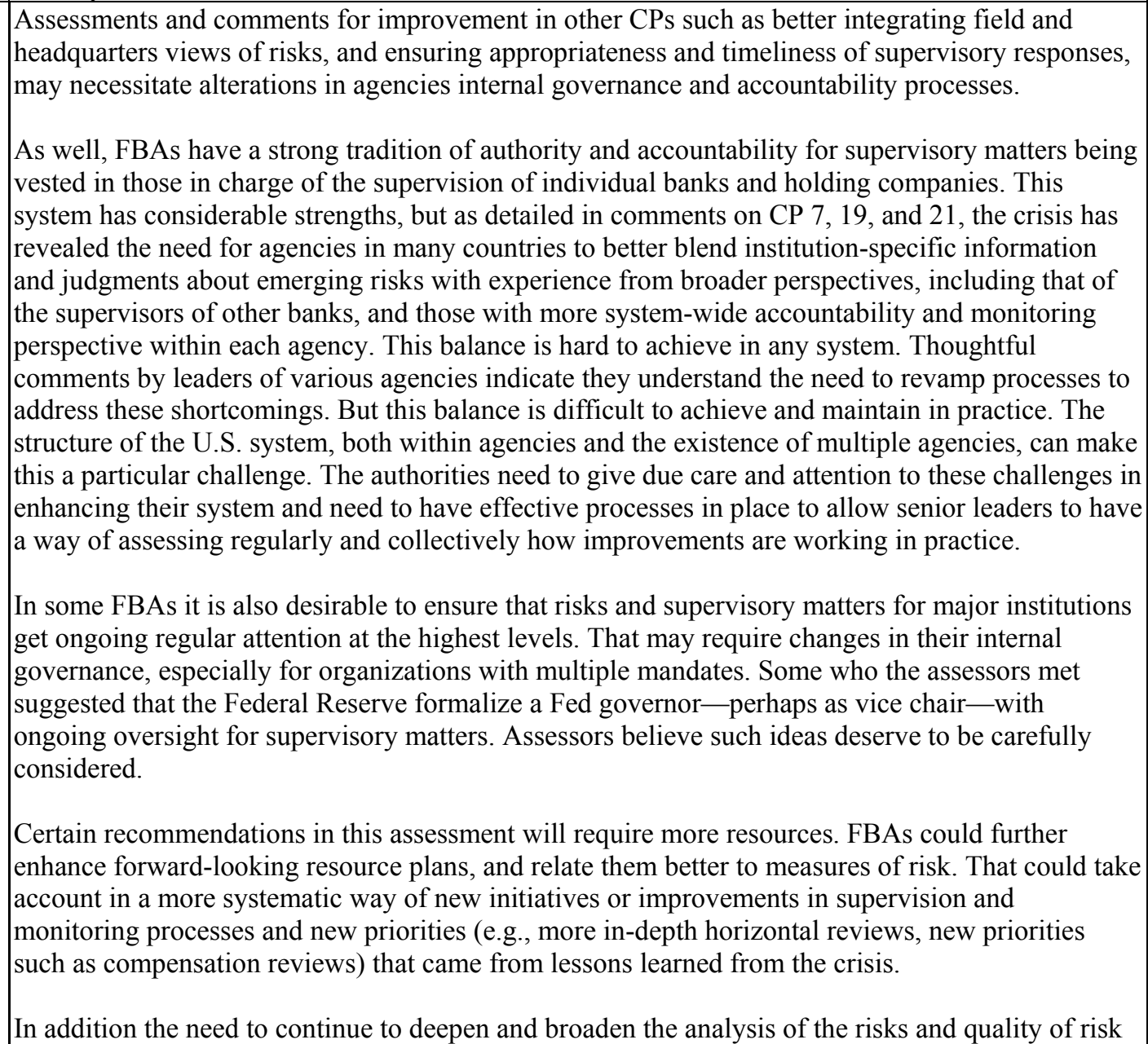 \\
\hline
\end{tabular}




\begin{tabular}{|c|c|}
\hline & 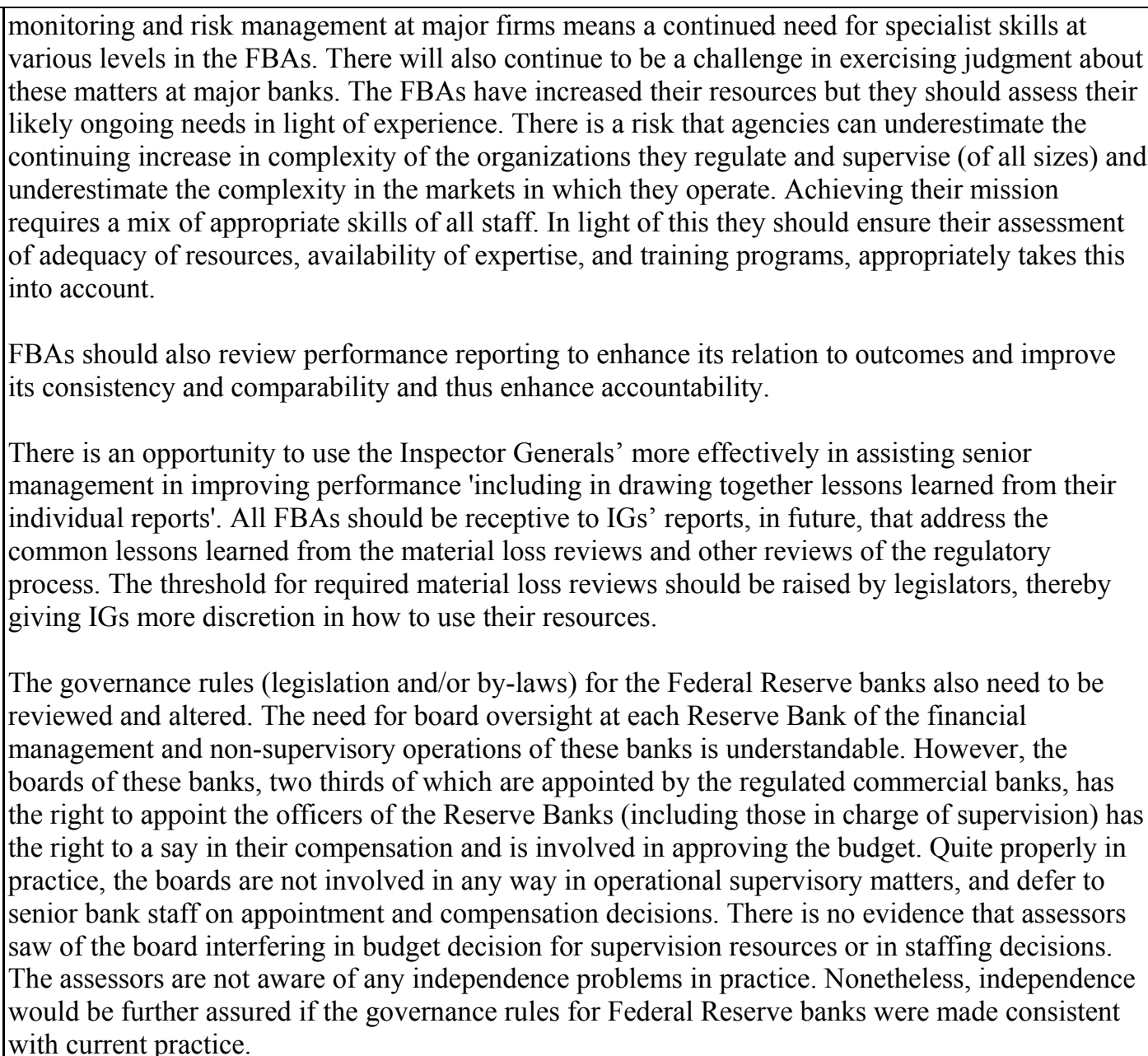 \\
\hline Principle 1(3). & $\begin{array}{l}\text { Legal framework. A suitable legal framework for banking supervision is also necessary, } \\
\text { including provisions relating to authorization of banking establishments and their ongoing } \\
\text { supervision. }\end{array}$ \\
\hline Description & 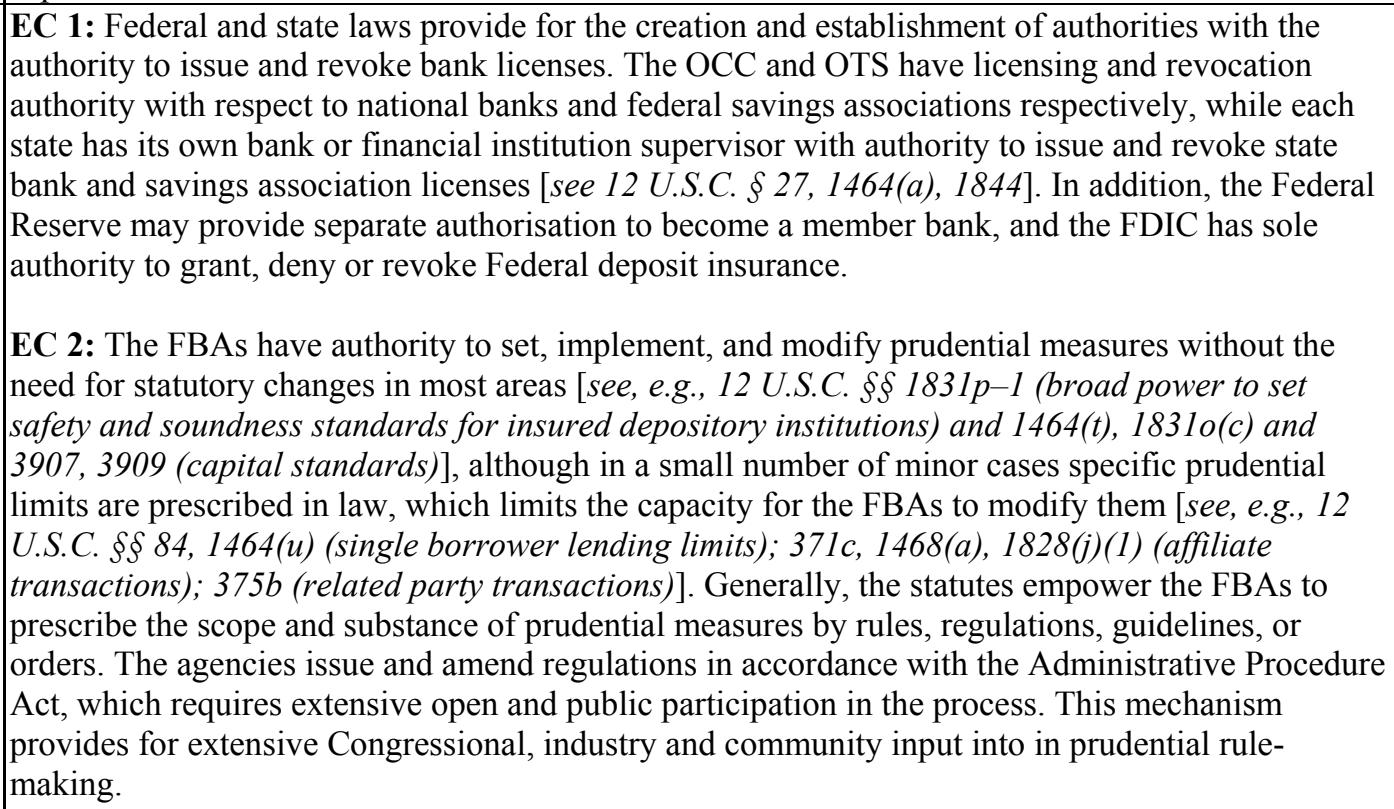 \\
\hline
\end{tabular}




\begin{tabular}{|c|c|}
\hline & $\begin{array}{l}\text { The FBAs have also published detailed compliance expectations and best practices, primarily in the } \\
\text { form of publicly available supervisory guidance and examination manuals, covering areas such as } \\
\text { internal controls, audit, information systems, risk management, and asset classifications and } \\
\text { valuations. The FBAs endeavour to update these materials as needed to reflect supervisory findings } \\
\text { and feedback, market developments and industry practices. These documents are not legally } \\
\text { binding or strictly enforceable, but are used by the FBAs to state their expectations with respect to } \\
\text { safe and sound banking practices. Issuance of guidance, interagency statements and examination } \\
\text { manuals does not need to go through a public consultation process as do legally-binding } \\
\text { regulations, although (with the exception of their examination manuals) the agencies often elect to } \\
\text { seek public comment in developing their guidance material. } \\
\text { EC 3: Collectively, the FBAs have broad authority under governing statutes and regulations to } \\
\text { obtain financial, structural, and any other information from banks and any of their affiliates } \\
\text { (including holding companies) in the form and with such frequency as the agencies deem necessary } \\
\text { (see CP } 21 \text { for further details). Broadly speaking, banks and holding companies are required to file } \\
\text { consolidated reports of condition with their primary FBA on a quarterly basis. The FBAs also } \\
\text { require the periodic submission of a host of additional information on banks and their affiliates. } \\
\text { The GLB Act, however, does impose some limits on the capacity of individual agencies to access } \\
\text { information, requiring instead that they rely to the extent possible on the activities of other } \\
\text { functional supervisors where these exist. }\end{array}$ \\
\hline Assessment & Compliant \\
\hline Comments & $\begin{array}{l}\text { Appropriate licensing authority exists although the fragmented U.S. system means that, somewhat } \\
\text { unusually, banks are able to choose their licensing authority, and hence have some degree of choice } \\
\text { as to which FBA(s) will have supervisory responsibility over them. Further details on licensing are } \\
\text { provided under CP } 3 \text {. } \\
\text { The GLB Act does limit information gathering powers to some extent, which (as discussed in CP } \\
19 \text { and CP 24) has an impact on the capacity of the authorities to conduct full and effective } \\
\text { consolidated supervision. The assessors noted that the U.S. Treasury proposes to remove some of } \\
\text { these limitations as part of the financial regulation reform proposals. }\end{array}$ \\
\hline Principle 1(4) & $\begin{array}{l}\text { Legal Framework. A suitable legal framework for banking supervision is also necessary, } \\
\text { including powers to address compliance with laws as well as safety and soundness concerns. }\end{array}$ \\
\hline Description & $\begin{array}{l}\text { EC 1: Statutes and regulation provide authority to supervisors to address compliance with laws and } \\
\text { the safety and soundness of institutions under their jurisdiction. In general, these authorities } \\
\text { provide supervisors with discretion in determining when supervisory action is warranted and a } \\
\text { range of proactive and remedial measures to address matters of concern. A statutory corrective } \\
\text { action mechanism has been implemented via the Prompt Corrective Action regime, designed to act } \\
\text { as a backstop by preventing forbearance involving banks with weakening capital positions [see } \\
12 \text { U.S.C. } 18310 \text { ]. However, even under this mandated process which requires a minimum set of } \\
\text { regulatory responses as a bank's capital position deteriorates, there is adequate scope for } \\
\text { supervisory judgement as to the most effective additional measures to use to achieve the correction } \\
\text { of capital weaknesses. } \\
\text { EC 2: Collectively, the FBAs have broad statutory authority to obtain a wide range of information } \\
\text { from supervised entities and their affiliates necessary to determine and enforce compliance with } \\
\text { applicable laws and ensure the safety and soundness of banks [see, e.g., } 12 \text { U.S.C. } \$ \$ 324-26 \text {, } 481 \text {, } \\
483,602,625,1467,1817,1820,1844,1867] \text {. Under the FBAs authority to conduct examinations, } \\
\text { banks and their affiliates must provide supervisors with full and complete access to their books, } \\
\text { records, and employees (including directors) or risk the imposition of administrative sanctions. } \\
\text { These obligations extend to the foreign operations of banks and their affiliates (subject to } \\
\text { confidentiality provisions in relevant foreign legislation). Where external audits are undertaken, the } \\
\text { FBAs also have full and complete access to the work papers, reports, and other relevant materials } \\
\text { of external auditors. } \\
\text { Given the predominance of the holding company structure in the U.S. banking system, agencies }\end{array}$ \\
\hline
\end{tabular}




\begin{tabular}{|c|c|}
\hline & $\begin{array}{l}\text { can face the challenge of accessing information about the broader corporate group in which an } \\
\text { individual bank is owned if they are to be able to comprehensively assess the risk profile of that } \\
\text { entity. As noted under CP 1(3), the GLB Act does impose some limitations on the capacity of an } \\
\text { individual agency to access information about an affiliate where another agency is the primary } \\
\text { functional supervisor of that affiliate. The FBAs have established a range of ad-hoc information- } \\
\text { sharing arrangements to endeavour to reduce the extent to which this impedes their ability to } \\
\text { complete their supervisory assessments. } \\
\text { EC 3: The FBAs have broad authority to impose remedial measures or sanctions when, in their } \\
\text { judgment, a bank or holding company is not complying with laws or regulations or is likely to be } \\
\text { engaged or is engaged in an unsafe or unsound practice. In these cases, the FBAs may require the } \\
\text { bank to take prompt remedial action or immediately cease and desist existing practice and may } \\
\text { impose a varying degree of sanctions depending on the gravity of the bank's violations, including, } \\
\text { where appropriate, revocation of the banking license. Evidence exists that compliance } \\
\text { powers/sanctions are routinely used. Further details are provided under CP } 23 \text {. }\end{array}$ \\
\hline Assessment & Compliant \\
\hline Comments & $\begin{array}{l}\text { Collectively, the FBAs possess the necessary powers of access, information gathering and } \\
\text { examination, and their use is clearly evident. Under the GLB Act, however, individual supervisors } \\
\text { can be dependent on their capacity to obtain information and supervisory assessments from } \\
\text { functional supervisory agencies if they are to be broadly informed. This problem has been } \\
\text { identified in the Treasury White Paper on Reforming Financial Regulation, and is discussed further } \\
\text { in CP } 24 \text {. }\end{array}$ \\
\hline Principle 1(5) & $\begin{array}{l}\text { Legal powers. A suitable legal framework for banking supervision is also necessary, including } \\
\text { powers to address compliance with laws as well as safety and soundness concerns. }\end{array}$ \\
\hline Description & $\begin{array}{l}\text { EC 1: The FBAs and their staff are well protected against lawsuits for actions and omissions while } \\
\text { discharging their duties in good faith. Sovereign immunity bars lawsuits without specific statutory } \\
\text { authorization to pursue such litigation. Common law qualified immunity protects FBAs' heads and } \\
\text { staff from liability for the violation of an individual's federal Constitutional rights in connection } \\
\text { with employees' performance of discretionary functions, as long as the employees' conduct does } \\
\text { not clearly violate established statutory or Constitutional rights. Lawsuits are permitted against } \\
\text { FBAs' employees for acts and omissions that cause injuries while acting within the scope of their } \\
\text { employment. In such a case, the United States would substitute itself as the defendant upon the } \\
\text { Attorney General's certification that an employee was acting within the scope of his office or } \\
\text { employment. Moreover, an exception to the relevant Act protects employees from lawsuits } \\
\text { involving the execution of a statute or regulation or the exercise/failure to exercise a discretionary } \\
\text { function, whether or not the employee abused the discretion involved. } \\
\text { EC 2: In practice (the number of actual cases are few), the FBAs protect their executives and staffs } \\
\text { against the cost of defending their actions and omissions made while discharging their duties in } \\
\text { good faith. }\end{array}$ \\
\hline Assessment & Compliant \\
\hline \multicolumn{2}{|l|}{ Comments } \\
\hline Principle 1(6). & $\begin{array}{l}\text { Cooperation. Arrangements for sharing information between supervisors and protecting the } \\
\text { confidentiality of such information should be in place. }\end{array}$ \\
\hline Description & $\begin{array}{l}\text { EC 1: The FBAs have broad statutory powers to share confidential business information collected } \\
\text { in the course of official duties. See } 12 \text { U.S.C. } \$ \$ 1817(a)(2)(A) \text { and }(C) \text { on sharing with FDIC, a } \\
\text { state or federal agency with supervisory or regulatory authority over the bank or other entity or } \\
\text { any appropriate person, and } 3412(\text { e) on sharing of financial records, examination reports or other } \\
\text { reports between the five FFIEC agencies, as well as the SEC, CFTC and FTC. The necessity of } \\
\text { maintaining the confidentiality of the information is highlighted in several statutory and regulatory } \\
\text { provisions, as is the requirement that the information be used for lawful supervisory purposes. The } \\
\text { FBAs have a number of formal and informal mechanisms for information sharing. By statute the } \\
\text { agencies are required to coordinate on certain matters through the FFIEC. These matters include }\end{array}$ \\
\hline
\end{tabular}




\begin{tabular}{|c|c|}
\hline & $\begin{array}{l}\text { examination procedures and shared access to electronic databases on supervisory information. } \\
\text { The Federal Reserve and the OTS make available relevant information to other banking agencies } \\
\text { and functional supervisors regarding operations of holding companies that may have a material } \\
\text { impact on an individual regulated subsidiary. Vice versa, functional regulators are expected to } \\
\text { inform the FBAs about developments which may have an adverse impact on banks within a } \\
\text { financial group (although, in practice this does not seem to occur more than exceptionally). } \\
\text { EC 2: The FBAs have concluded cooperation agreements with a number of foreign banking } \\
\text { supervisors. Additionally, FBAs have exchanged letters outlining the conditions under which } \\
\text { information could be shared on a best effort, case-by-case basis with several other countries. The } \\
\text { FBAs also routinely share information with financial supervisors from other countries on an } \\
\text { informal basis. In the experience of the FBAs both the formal and the informal arrangements work } \\
\text { in practice. } \\
\text { EC 3: The FBAs are authorized by statute and regulation to share information with domestic and } \\
\text { foreign financial supervisors. Prior to engaging in information sharing, assurances are required that } \\
\text { the information will be used only for lawful supervisory purposes and will be kept confidential. } \\
\text { Under the International Banking Act, the agencies must determine that disclosure is appropriate } \\
\text { and would not prejudice the interest of the United States. The agencies must also obtain the } \\
\text { recipient's agreement to keep the information confidential to the "extent possible under applicable } \\
\text { law." See } 12 \text { U.S.C. } \$ 3109 \text { (b). } \\
\text { EC 4: The FBAs are able to deny demands for confidential information in their possession except } \\
\text { in limited situations. Such information may be subpoenaed by a court, a grand jury, or a committee } \\
\text { of the U.S. Congress. When feasible, an agency that is being compelled to provide confidential } \\
\text { information received from another supervisor will notify such supervisor and make reasonable } \\
\text { efforts to resist disclosure. The FBAs also must notify U.S. law enforcement authorities if they } \\
\text { receive indications of a possible violation of criminal law. }\end{array}$ \\
\hline Assessment & Compliant \\
\hline Comments & $\begin{array}{l}\text { An ad-hoc structure of -information-sharing and confidentiality arrangements have been } \\
\text { established to facilitate and improve information-sharing between relevant agencies, as required by } \\
\text { this CP. However, as noted in a number of CPs (particularly CP 24), there remain deficiencies in } \\
\text { consolidated oversight. } \\
\text { While rightly focusing on information sharing (which is compliant) as the basis of cooperation and } \\
\text { coordination, this CP also deals with evidence that cooperative arrangements work in practice. The } \\
\text { assessors evidenced many examples of high quality cooperation between the FBAs in practice. In } \\
\text { many ways the FBAs have been very innovative in finding cooperative ways to deal with some of } \\
\text { the structural weaknesses and challenges in their system that come from the legal framework which } \\
\text { does not match the way banks do business and organize themselves. There are many examples of } \\
\text { extraordinary efforts by dedicated staff to cooperate to get the job done, particularly in the recent } \\
\text { crisis. It was interesting that several senior people assessors met noted two initiatives at least partly } \\
\text { driven by outside events-the recent SCAP process and Basel II implementation-as recent } \\
\text { examples of cooperative processes that they wish to build on. } \\
\text { The assessors saw examples where opportunities for cooperation and coordination and learning } \\
\text { from best practice in other FBAs were missed. There were also examples where opportunities } \\
\text { seemed to be missed for constructive challenge using judgment based on a shared fact base. Taken } \\
\text { individually, none of these is crucial. But given the likely continued challenges facing the } \\
\text { authorities, taken together they suggest a need for the FBAs to redouble their efforts at all levels of } \\
\text { the organization to cooperate and coordinate and design processes to maximize coordination and } \\
\text { the benefits from constructive challenge. }\end{array}$ \\
\hline Principle 2. & $\begin{array}{l}\text { Permissible activities. The permissible activities of institutions that are licensed and subject to } \\
\text { supervision as banks must be clearly defined and the use of the word "bank" in names should be } \\
\text { controlled as far as possible. }\end{array}$ \\
\hline
\end{tabular}




\begin{tabular}{|c|c|}
\hline Description & 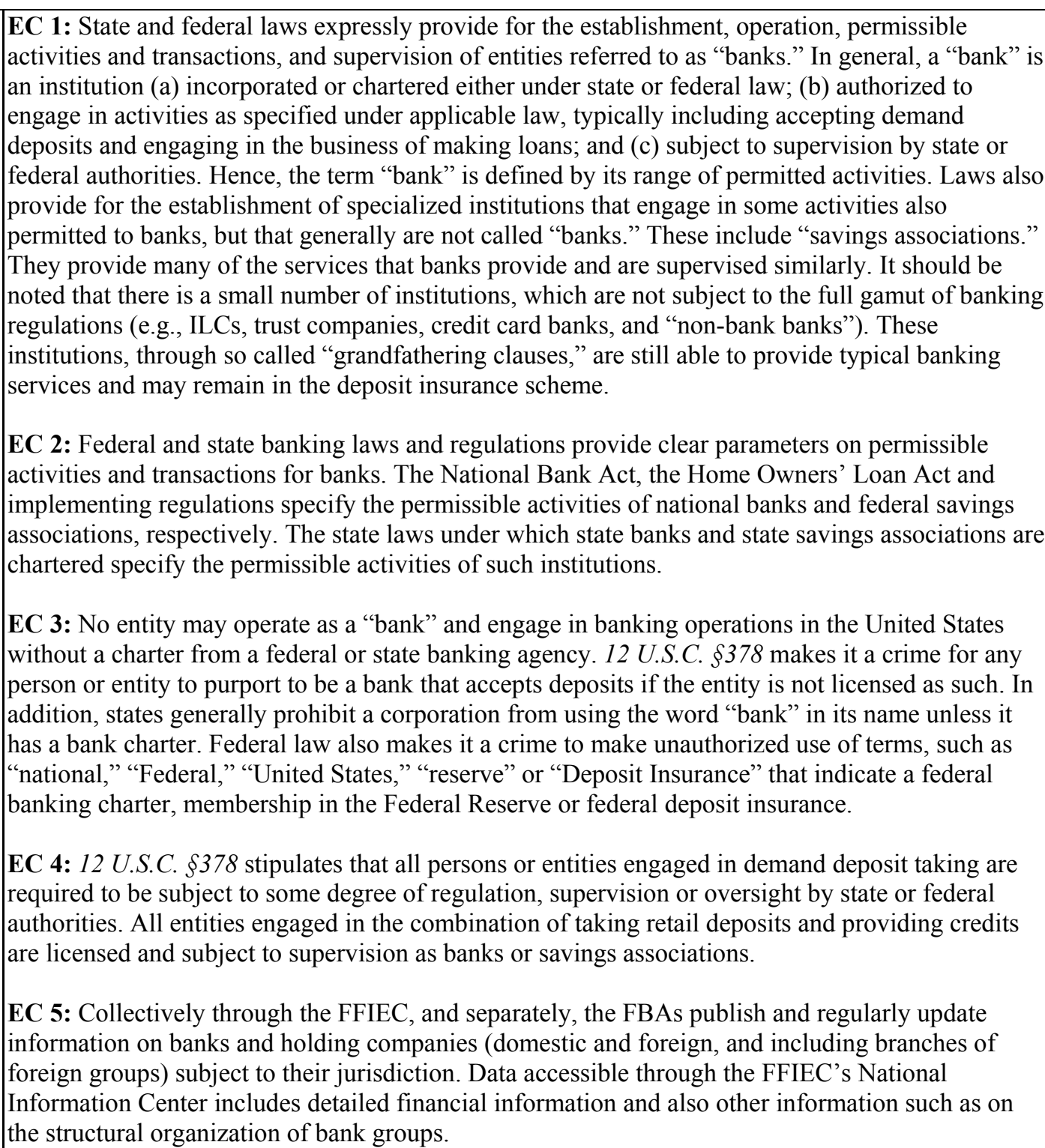 \\
\hline Assessment & Compliant \\
\hline \multicolumn{2}{|r|}{$D^{\prime}$} \\
\hline Principle 3. & $\begin{array}{l}\text { Licensing criteria. The licensing authority must have the power to set criteria and reject } \\
\text { applications for establishments that do not meet the standards set. The licensing process, at a } \\
\text { minimum, should consist of an assessment of the ownership structure and governance of the bank } \\
\text { and its wider group, including the fitness and propriety of board members and senior management, } \\
\text { its strategic and operating plan, internal controls and risk management, and its projected financial } \\
\text { condition, including its capital base. Where the proposed owner or parent organization is a foreign } \\
\text { bank, the prior consent of its home country supervisor should be obtained. }\end{array}$ \\
\hline Description & $\begin{array}{l}\text { EC 1: Banks are regulated and supervised by their licensing authority They are also subject to } \\
\text { concurrent regulation and supervision by one or more additional banking agencies. Establishing a } \\
\text { de novo bank always involves obtaining related federal deposit insurance, and often involves } \\
\text { additional authorizations, such as membership in the Federal Reserve System, from more than one } \\
\text { agency. The relevant authorities have well-established practices and procedures to communicate } \\
\text { and coordinate investigations on related licensing and deposit insurance applications. }\end{array}$ \\
\hline
\end{tabular}


EC 2: The authority to license banks and the criteria to be considered are set forth in statutes and regulations. The authority for licensing national banks is conferred on the OCC, see 12 U.S.C. $\$ 21$ et seq. Similarly, the OTS is authorized to license federal savings associations, see 12 U.S.C. § 1464(a). In addition, each of the states has the authority to license banks operating within its jurisdiction. The FDIC alone is authorized to make determinations regarding deposit insurance under the FDI Act

EC 3: Although not expressly required by the statute, the criteria for issuing licenses are generally consistent with those applied in ongoing supervision. For instance, the OCC considers whether the applicant bank: (a) has organizers who are familiar with national banking laws and provisions; (b) has competent management with ability and experience relevant to the services to be provided and the volume and type of risks to be assumed; (c) has capitalization, access to liquidity, and riskmanagement systems sufficient for the projected volume and type of business; (d) can reasonably be expected to achieve and maintain profitability; and (e) will operate in a safe and sound manner. See 12 CFR 5.20(f)(2).

When evaluating applications for deposit insurance, the FDIC considers seven statutory factors enumerated in Section 6 of the FDI Act. These factors assess the financial history and condition of the proposed depository institution and its parent organization, capital structure, proposed ownership and management, earnings prospects, activities to be conducted, convenience and needs of the community to be served, and potential risks to the Deposit Insurance Fund. Also important to the assessment of deposit insurance applications is the complexity and unique nature of the underlying proposal and business plan, including the conditions under which the proposed institution will operate.

EC 4: Each licensing agency has the authority to deny an application if it determines that the applicant has not met the established criteria or if the information is inadequate. Before granting the license the agencies must evaluate the evidence and conduct investigations and exercise independent judgment in determining whether the qualifying criteria are met.

EC 5: An essential element of the licensing process is to develop thorough understanding of the proposed legal, managerial, operational and ownership structure of a bank, both on a solo and consolidated basis. If impediments for effective supervision on a solo and consolidated basis exist, the agencies may take remedial measures, including denying a license, deposit insurance coverage, or Federal Reserve membership.

EC 6: Applicants are required to identify prospective shareholders and key policymakers, including beneficial owners. Principal prospective shareholders, generally those owning 10 percent or more of a class of a bank's shares, and key policymakers who are not previously known to the licensing authorities must provide detailed information on their current and past work experience and financial holdings. The agencies will investigate information on integrity, criminal convictions, financial capacity and expertise in the industry. The assessment will also consider whether principal shareholders have the ability to provide financial support to the proposed bank. This includes identifying the sources of initial capital and ensuring transparency of ownership structures. The agencies will verify the information provided about beneficial owners.

EC 7: Although the OCC does not stipulate a minimum capital amount for national banks, but sufficient net initial capital to support the "projected volume and type of business," they are de facto subject to a minimum of US\$2 million since that is the required amount by the FDIC for inclusion in the deposit insurance scheme. Before granting the license the agency will verify that the required capital funds are fully available and on deposit with the institution's correspondent bank. The initial required capital of a federal savings association is also US\$2 million, although OTS, like the OCC, requires sufficient net capital to support the bank's proposed business plan.This often implies a higher capital requirement than the minimum. A US\$10 million capital requirement would be typical for a bank planning to grow to US\$100 million assets in the start-up phase. 
EC 8: The licensing agencies evaluate proposed directors and senior management with respect to expertise, integrity, and any potential for conflicts of interest. The agencies generally consider each individual's (a) financial institution and other business experience; (b) duties and responsibilities with respect to the proposed bank, holding companies and affiliates; (c) personal and professional financial responsibility, e.g., indicated by earlier professional experiences; (d) reputation for honesty and integrity, i.e., verified by (lack of) criminal or other records; and (e) familiarity with the economy, financial needs, and general character of the community in which the bank will operate. Applicants must demonstrate that each director has sufficient competence, experience and ability to direct the policies of the bank in a safe and sounds manner. Also key bank officers must show their ability to perform their duties successfully, e.g., in interviews with the licensing staff.

EC 9: Applicants must show that the proposed strategic and operational plans are viable and that the proposed management team has the ability to implement the plans successfully. Typically, the plan must contain a documented analysis of the market environment and financial projections based on reasonable assumptions. To evaluate corporate governance structures, the agencies seek to understand the board's involvement in setting and enforcing clear lines of responsibility and accountability by reviewing organizational charts, business plans, and proposed policies and procedures. The agencies specifically determine how a bank's board of directors will approve, oversee, and communicate the bank's strategic objectives and otherwise exercise its fiduciary responsibilities. The agencies will also consider the relationship between the proposed bank and any related parties. This includes evaluating potential conflicts of interest, terms and conditions of any transactions or business relationships, and the terms of compensation plans. With respect to risk-management systems and policies, applicants are expected to develop appropriate written investment, loan, funds management, and liquidity policies. They also must establish an internal control structure and audit program, including exercising appropriate oversight over outsourced functions. The operational structure and risk-management framework are expected to be consistent with the complexity, risk, and scope of proposed operations.

EC 10: Since a proposed de novo bank has no financial history, an evaluation of the reasonableness of the financial projections is paramount in the licensing process. Also critical is an assessment of the adequacy of financial strength to support the strategic plan. Estimates must be fully documented and supported by established growth patterns in the applicant's specific market area. Agencies will also evaluate concentration of funding sources for safety and soundness concerns and determine whether contingency funding plans are adequate for the bank's complexity and risk profile. The applicant must demonstrate that the proposed bank can achieve stabilized operations and be operated profitably within a reasonable period, typically, three years.

EC 11: Foreign banks establishing a branch, agency, or a subsidiary bank in the U.S. must obtain approval both from the licensing authority and the Federal Reserve. The licensing authority may, and the Federal Reserve must, determine that the foreign bank and any parent foreign bank are subject to consolidated supervision by its home country supervisor. They also routinely contact the home country supervisor in order to take into account whether it has approved, or expressed no objection, to the proposal. Similar procedures apply before establishing or acquiring a subsidiary savings association in the US. In these cases the OTS will make the corresponding determinations.

EC 12: Providing false or misleading information can form a basis for civil, administrative and criminal liability, and the penalties can include license revocation. See 12 U.S.C. $\$ 93($ a). Similar representations are made on applications for federal deposit coverage and for membership in the Federal Reserve. See 12 U.S.C. $\$ 327$ (forfeiture of Federal Reserve membership).

EC 13: The licensing agencies require applicants to show that members of a bank's board of directors have the ability to establish and operate a bank in a safe and sound manner. At a minimum, this presumes that the board, collectively, has a sound knowledge of each of the types of activities the bank intends to pursue and the associated risks. 


\begin{tabular}{|c|c|}
\hline & $\begin{array}{l}\text { AC 1: Assessments regarding principal shareholders consider whether they have the ability to } \\
\text { provide financial support. When applicable, a holding company is expected to serve as a source of } \\
\text { financial strength to its subsidiary banks. It is expected to provide capital funds in times of stress. It } \\
\text { is also expected to maintain capital-raising capacity to obtain additional resources to assist } \\
\text { subsidiary banks. } \\
\text { AC2: The FBAs monitor the progress of de novo banks in meeting business plans and strategic } \\
\text { plans for a period after licensing, usually two to three years, during annual on-site reviews. There is } \\
\text { also an early examination of the banks after its start, to ensure that required polices, processes and } \\
\text { systems are in place. The banks must also give the agencies prior notice of any change in the } \\
\text { bank's business plan during the first three years. }\end{array}$ \\
\hline Assessment & Compliant \\
\hline Comments & 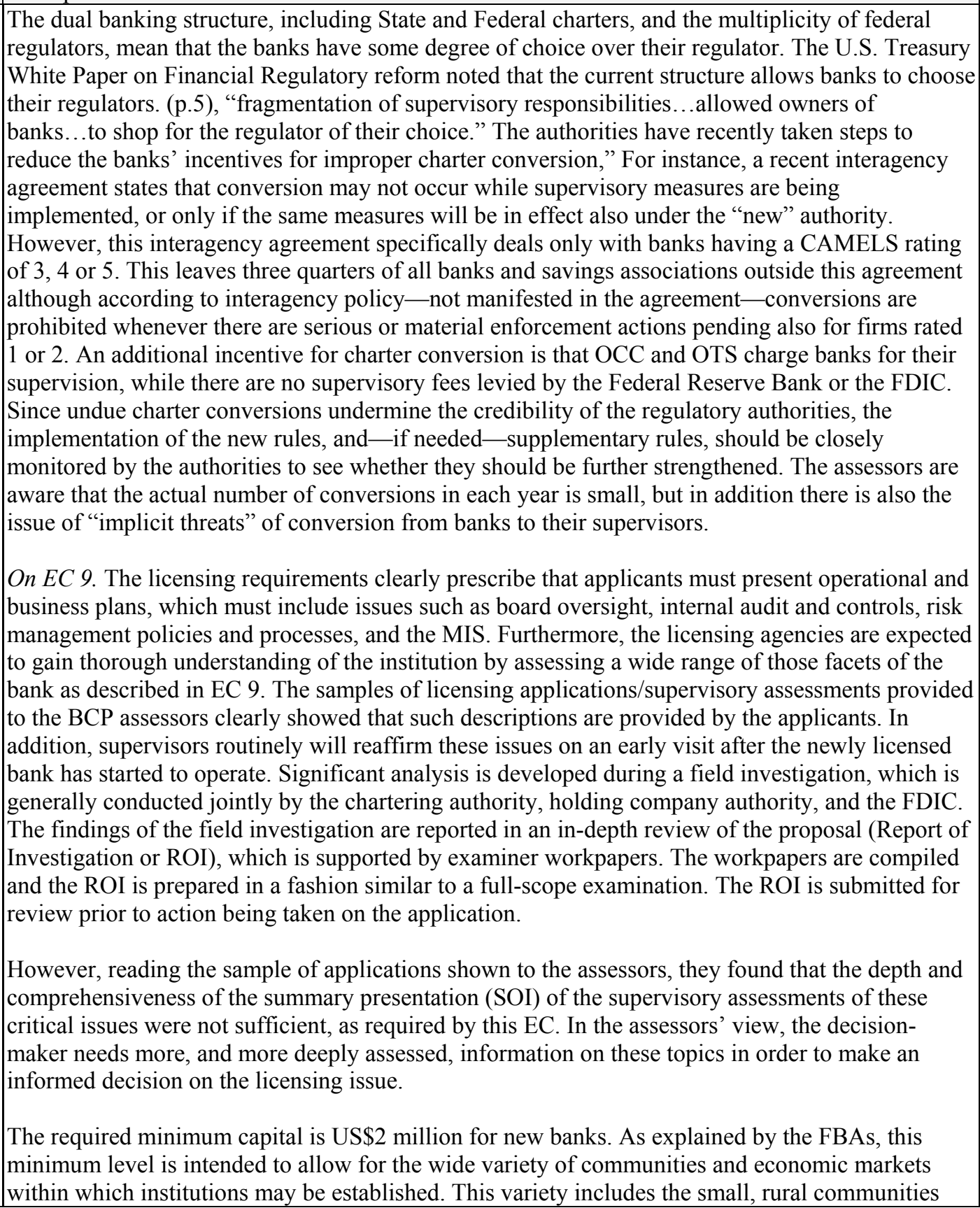 \\
\hline
\end{tabular}




\begin{tabular}{|c|c|}
\hline & $\begin{array}{l}\text { that support locally-owned institutions, which generally require comparatively less capital than } \\
\text { full-service institutions organized in large metropolitan areas. That said, the US } \$ 2 \text { million level is } \\
\text { lower than the corresponding level in many other countries, which also have small local banks. It } \\
\text { should be noted, though, that in practice, capital contributions are significantly above the minimum } \\
\text { of US } \$ 2 \text { million. }\end{array}$ \\
\hline Principle 4. & $\begin{array}{l}\text { Transfer of significant ownership. The supervisor has the power to review and reject any } \\
\text { proposals to transfer significant ownership or controlling interests held directly or indirectly in } \\
\text { existing banks to other parties. }\end{array}$ \\
\hline Description & 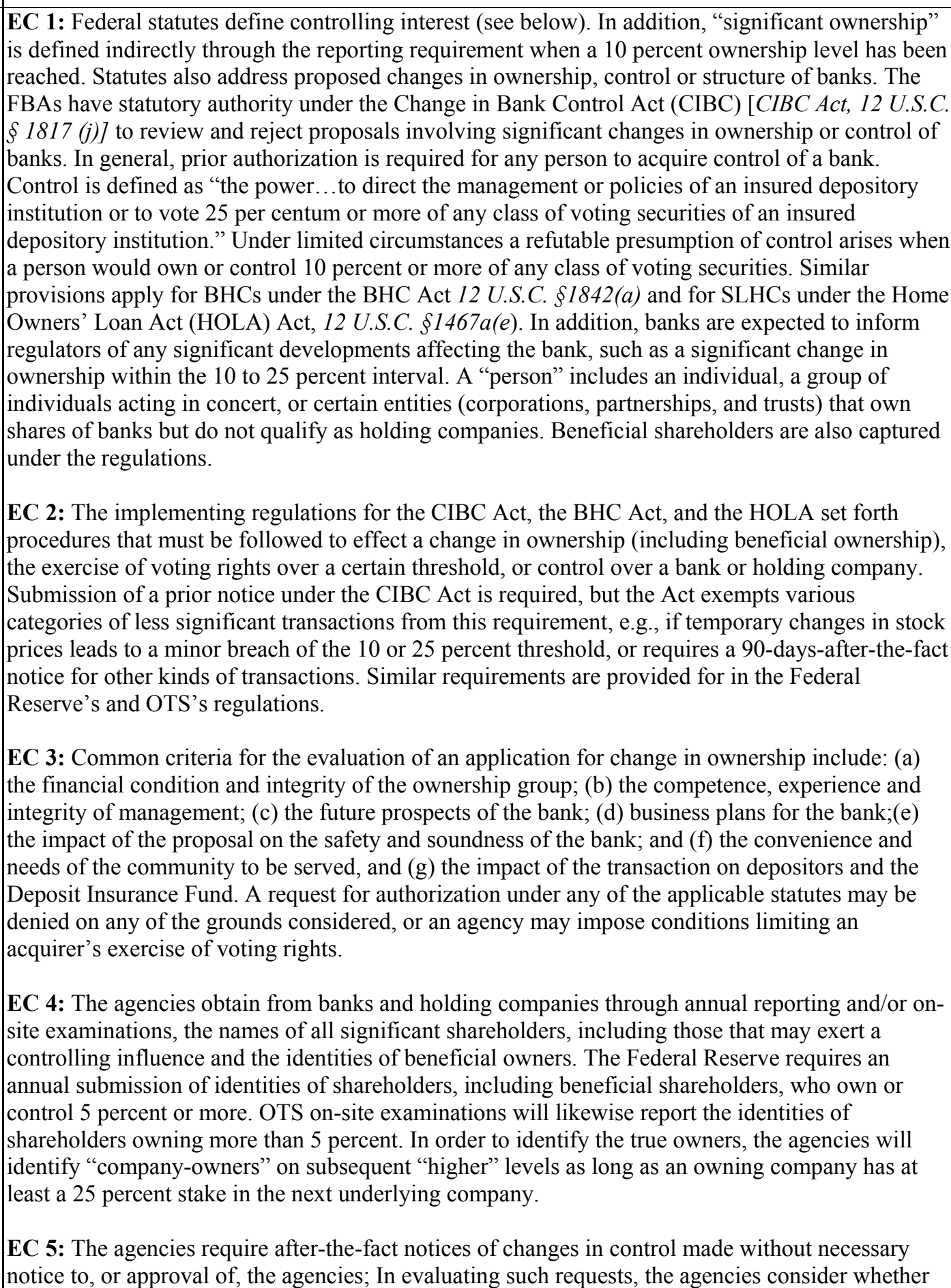 \\
\hline
\end{tabular}




\begin{tabular}{|c|c|}
\hline & $\begin{array}{l}\text { the failure to request authorization in the first instance was a knowing violation of law (which } \\
\text { could lead to monetary or other penalties). The agencies also consider whether appropriate } \\
\text { procedures have been put in place to ensure that further violations do not occur. The agencies have } \\
\text { the authority to deny or condition an after-the-fact request for authorization. They may also call for } \\
\text { the unwinding of a change in ownership transaction. } \\
\text { AC1: The agencies expect controlling shareholders, or the bank(s) with which they are affiliated, } \\
\text { to provide the agencies with timely notice of any material information that would impact the } \\
\text { shareholders' continued suitability. A failure to disclose such information would trigger legal } \\
\text { provisions which could lead to sanctions. See, } 12 \text { U.S.C. } \xi 164(a)(1)(B) \text {. At times, FBA supervisors } \\
\text { meet with, and assess, principal shareholders. }\end{array}$ \\
\hline Assessment & Compliant \\
\hline Comments & \\
\hline Principle 5. & $\begin{array}{l}\text { Major acquisitions. The supervisor has the power to review major acquisitions or investments by } \\
\text { a bank, against prescribed criteria, including the establishment of cross-border operations, and } \\
\text { confirming that corporate affiliations or structures do not expose the bank to undue risks or hinder } \\
\text { effective supervision. }\end{array}$ \\
\hline Description & 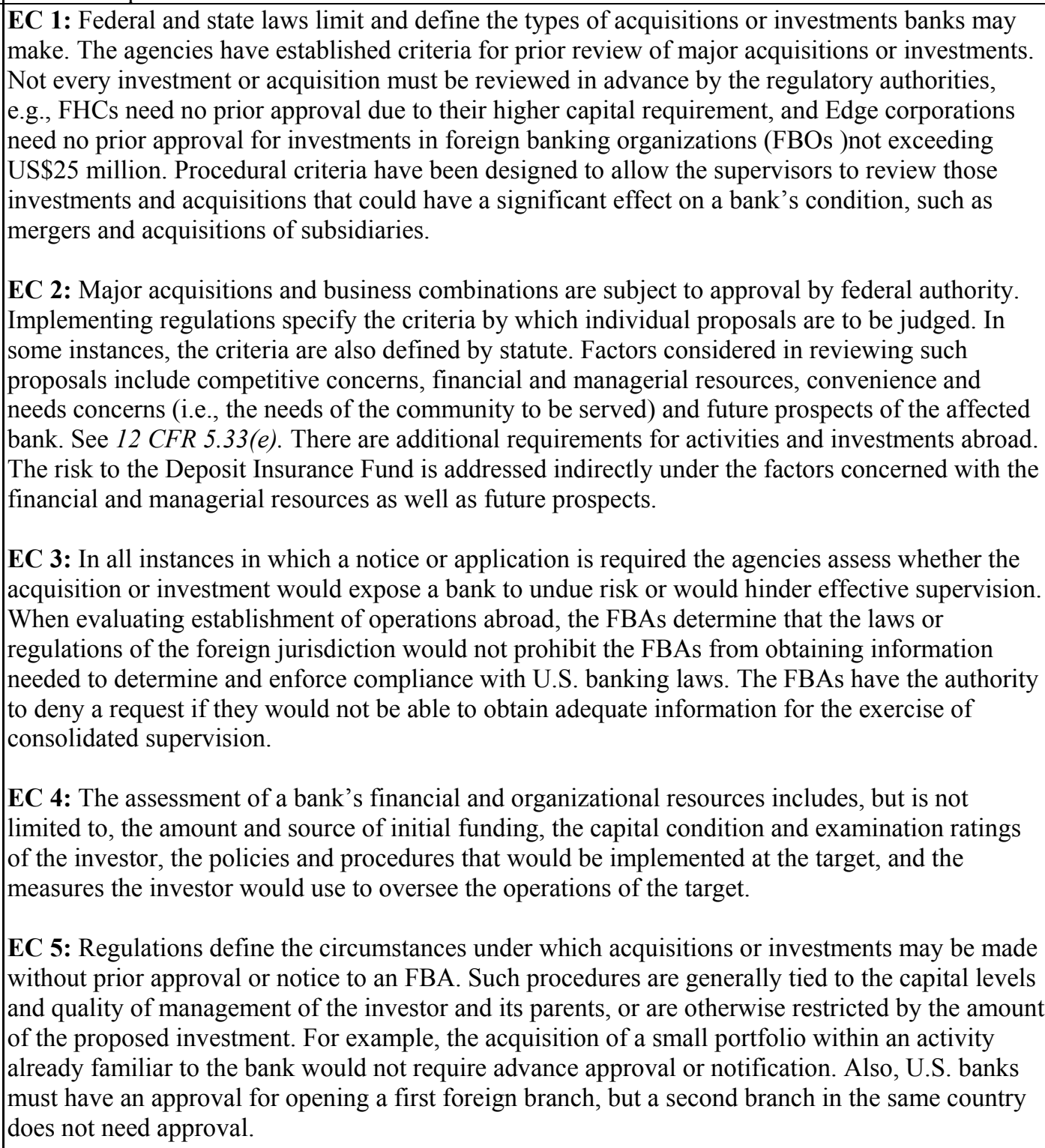 \\
\hline
\end{tabular}




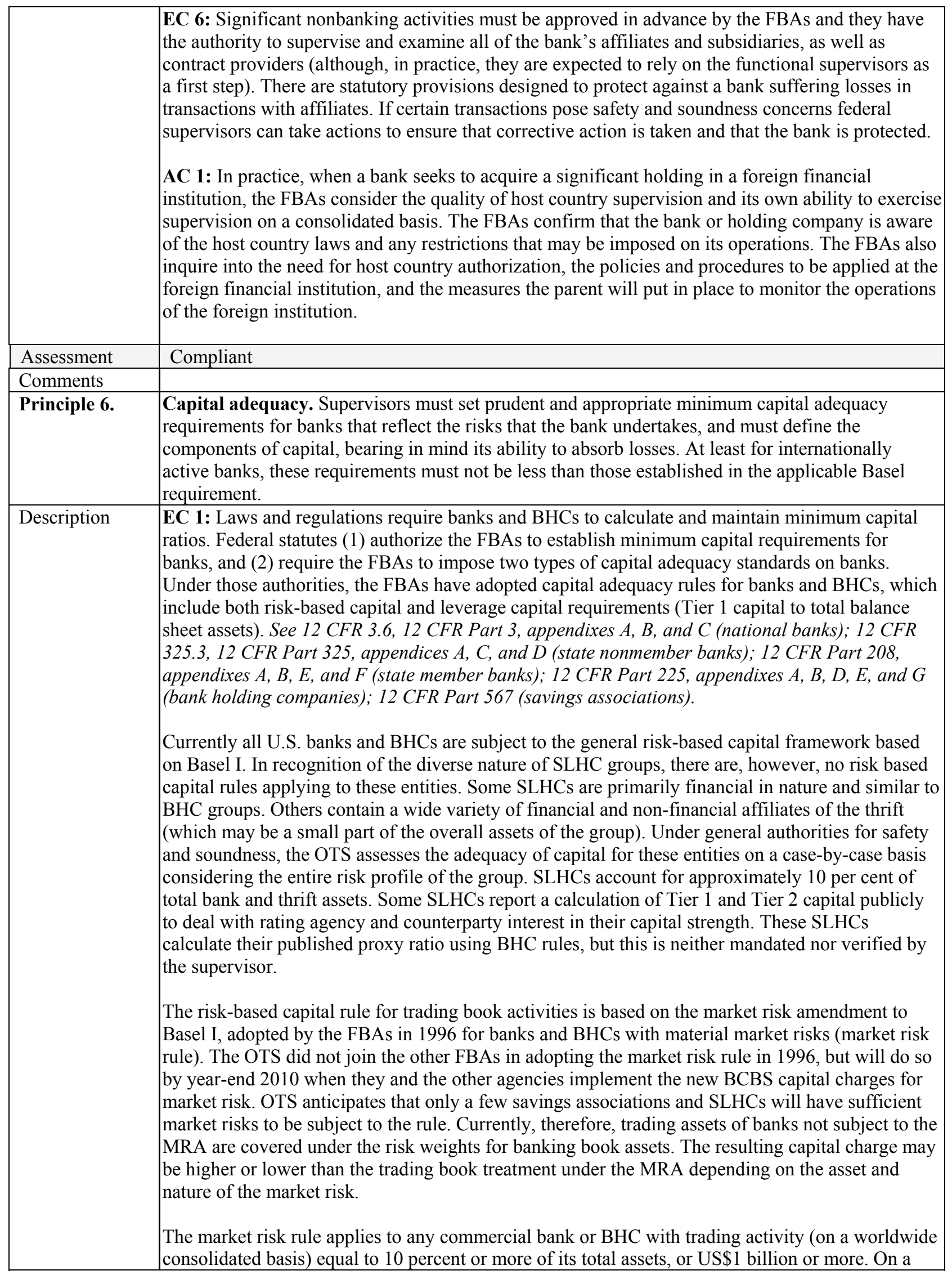


case-by-case basis, the FBAs may require a bank or BHC that does not meet the applicability criteria to comply with the market risk rule if deemed necessary for safety-and-soundness reasons (see AC 5), or may exclude a bank or BHC that meets the applicability criteria if its recent or current exposure is not reflective of the level of its ongoing trading activity. A bank or BHC that does not meet the applicability criteria may, subject to supervisory approval, comply voluntarily with the market risk rule. FBAs report this happens rarely. Approximately 30 banking groups were subject to the market risk rule at the time of the assessment.

For foreign banks with a branch or agency, to qualify for FHC status, the foreign bank has to meet the well capitalized standard consistent with the domestic PCA regime (6 percent Tier 1, 10 percent Total capital - usually based on home country calculations - with no explicit leverage requirement). Foreign branches also have to meet an asset maintenance requirement in the United States with a margin of assets over liabilities.

Former investment banks that are now BHCs must compute consolidated capital under the Basel I risk-based capital rules. They were previously subject to the Basel-II-based SEC capital rules. These institutions are transitioning to Basel II rules.

The leverage capital requirement supplements the risk-based capital requirement and establishes a minimum ratio of a bank's or BHC's Tier 1 capital to average total consolidated balance-sheet assets. The leverage ratio limits the extent to which a bank or BHC is able to fund itself with debt.

Banks and BHCs are subject to Tier 1 and total risk-based capital ratio requirements on a consolidated basis. The minimum capital requirements for individual banks and BHCs are 4 percent Tier 1 risk-based capital, 8 percent total risk-based capital, and 4 percent Tier 1 leverage capital (3 percent Tier 1 leverage capital is the minimum requirement for banks and BHCs rated composite 1 under their respective rating systems and for BHCs that have implemented the market risk rule). Most banks and BHCs operate with capital levels well above these minimum requirements.

Laws, regulations and guidelines for banks and BHCs define the components of capital. While in general emphasis is given to those elements of capital available to absorb losses, as noted in EC 2 there are also material elements in the definition of capital that the assessment team questioned from that perspective.

To qualify as Tier 1 or Tier 2 capital, the capital instruments must be unsecured, and may not contain or be covered by any covenants, terms, or restrictions that are inconsistent with safe and sound banking practices. See section 3020 of the Federal Reserve's Commercial Bank Examination Manual (CBEM), the Comptroller's Corporate Manual on Capital and Dividends (November 2007), the FDIC's Risk Management Manual of Examination Policies (Section 2.1 - Capital) and Section 0100 of the OTS Examination Handbook for a full definition and description of Tier 1 and Tier 2 capital.

Tier 3 capital is permitted to protect against market risks. Tier 3 capital is unsecured subordinated debt that has several other characteristics that are described in the market risk rule. Use of Tier 3 capital is rare.

The FBAs have implemented what they describe as 'bifurcated' capital requirements for banks and BHCs.

A new risk-based capital framework (based on the advanced approaches in the Basel II framework), is mandatory for "core banking organizations" and available on a voluntary basis to other banks and BHCs. This rule is enacted and implementation is in progress. Banks and BHCs are only eligible to calculate their regulatory capital based on this rule starting no earlier than 2011, once they have met a range of qualifying criteria including successfully completing a parallel run over a minimum of four quarters. FBAs must approve a banking organisation moving out of the 
parallel run. Core banking organizations include banks and BHCs that have US\$250 billion or more of total consolidated assets or US\$10 billion or more of on-balance-sheet foreign exposure. At the time of assessment, implementation plans have been received from 14 core banking organizations. As this rule is not yet the basis for banks' capital calculations, it was not assessed in detail in this FSAP. However given the imminent implementation the assessors performed a high level review of the state of implementation and provided separate comments to the FBAs.

The FBAs have also issued a proposed rule that would implement the Basel II standardized approach (standardized approach rule) with certain modifications to address U.S. markets, most notably residential mortgages. The proposal would permit banks and BHCs (other than core banking organizations subject to the advanced approaches final rule) to choose to remain under the current risk-based capital rule or opt into the standardized approach rule as described in the proposal. See 73 Fed. Reg. 43982 (July 29, 2008). Comments were received on this proposal but the implementing rule has not been finalized, and there is no publicly-announced date for its introduction. Accordingly, it was not included in this assessment.

EC 2: The FBAs reported that the definition of capital, the method of calculation, and the minimum ratios required for U.S. banks and BHCs (as discussed in EC 1 above) are based on the Basel I Capital Accord (including the market risk amendment for commercial banks). While the Basel I Accord does not formally apply to holding companies, BHCs and banks in the U.S. are intimately related, and U.S. authorities have long held out that their capital rules for those entities are based on Basel rules. The Basel II rules, including the definition of capital, do apply formally to holding companies.

The assessors reviewed these rules and discussed certain matters with the authorities. The risk weights and other aspects of the calculation of capital requirements for the general risk based capital rule including national discretion choices are essentially consistent with Basel I.

An exception is the capital requirement for market risk, which only applies to certain large, complex, commercial banks and BHCs, which the authorities consider internationally active. The FBAs report that the market risk component in smaller banks is not large. As well, for smaller banks' exposures, banking book treatment could often result in higher capital than trading book treatment.

The assessors discussed aspects of the definition of capital applying to banks, BHCs and SLHCs. The definition of Tier 1 capital applying to BHC's may, in the case of innovative instruments, depart from the Basel requirements.

The limit of innovative instruments included in Tier 1 capital for the largest BHCs is 15 percent (the mandatory, "core" Basel II banks), which is the limit in the BCBS rules on innovative instruments. However, for other BHCs, including those that opt in to the advanced approaches rule, the limit on innovative instruments is set at 25 percent.

In addition, cumulative preferred shares and cumulative trust preferred securities are included in the $15 / 25$ percent limit, which would not normally be the case under either the BCBS rules or the published 1998 BCBS standards on innovative instruments. To qualify in Tier 1 capital under these rules, such instruments would have to be non-cumulative (as non-cumulative instruments are more loss absorbing).

As with innovative instruments in other countries, these instruments count as Tier 1 capital, but returns paid on certain of them (i.e., trust preferred securities) are tax deductible. Authorities indicated that other features of these instruments meant their loss-absorption ability was appropriate for inclusion in Tier 1 . They also noted that this flexibility in instruments allowed in Tier 1 capital was important to ensure a level playing field between the U.S. and practice in other jurisdictions. 
These instruments make up 10-15 percent on average of consolidated Tier 1 capital of the 14 "core" BHC's (those under the advanced approaches rule).

More recently, cumulative preferred shares beyond the 15/25 percent limit issued by BHCs and SLHCs as part of the Troubled Asset Relief Program (TARP) plan are included in Tier 1 capital through specific changes to the risk-based and advanced approaches capital rules. Again, to be eligible under Basel rules these instruments would be required to be non-cumulative. These are important sources of reported Tier 1 capital for some entities at the time of the assessment

Risk-based capital rules at the bank level in a corporate group do not permit these instruments. The rules for these instruments at the holdco level are carried forward into the advanced approaches capital rule in the United States, now enacted, that will apply shortly, and that is not compliant with the Basel II requirements in this regard.

The capital rules also allow certain intangibles to count as capital. The assessors discussed the issue of mortgage servicing rights (MSRs) with the authorities. Mortgage servicing rights are the valuation assigned to the payment stream a bank can earn for managing (i.e., "servicing") a mortgage portfolio that is held by another investor.

The U.S. authorities do not require the automatic deduction of MSRs from capital for banks and BHCs. The U.S. provides for a category of "qualifying intangibles" which do not need to be deducted. These include MSRs, as well as non-mortgage servicing rights (NMSRs) and purchased credit card receivables (PCCRs). The latter are typically of lesser materiality for the larger banks. The FBAs consider that qualifying intangibles deserve special consideration on the basis that (i) they can be separated from and sold by the bank, (ii) the market value can be established by verifiable means, and (iii) a market exists for these assets.

Qualifying intangibles may be included in capital up to 100 percent of Tier 1 capital, of which no more than 25 percent can consist of NMSRs and PCCRs. The Basel definitions of capital only require deduction of 'goodwill,' and these intangibles are not considered goodwill in the U.S. The issue is not the failure to deduct these amounts. Rather the issue is that because of the absence of lower limits, intangibles can be a very material part of Tier 1 capital

Capital derived from MSRs can be material. MSRs typically amounted to 10-20 percent of Tier 1 capital for a number of the largest banks, were in the range of 40 percent of Tier 1 capital for some banks, and were 75 percent to over 100 percent of Tier 1 at a small number of institutions (including some that failed).

For SLHCs, as noted earlier, there are no specific capital rules. Instead, the authorities consider a variety of factors in determining the adequacy of an entity's capital. For financial SLHC groups that are similar to BHCs, one factor is a proxy capital calculation according to the BHC risk-based capital (Basel I) rules. However, other factors (such as experience in comparable non-financial peers) may be taken into account, particularly in the case of SLHCs with material non-financial affiliates as part of the group.

In the recent SCAP exercise FBAs considered capital needs of banks based on a range of indicators of capital adequacy including Tier 1, pro-forma equity capital, and considered the composition of capital. FBAs reported in the SCAP their longstanding desire that common equity, without the elements reported above, should be the predominant form of capital. As noted above, the issue is the extent to which this is applied on an on-going basis in practice.

EC 3: The risk-based capital rules require banks and BHCs to hold capital commensurate with the level and nature of all risks to which they are exposed. The agencies have broad statutory authority to establish minimum capital levels for a bank or BHC (reference 12 USC $\$ 3907(a)(2))$. They also have authority under risk-based capital rules to impose capital charges on specific exposures if the charge under the rule is not appropriate for the exposures. The capital rules do not give FBAs the 
power to directly limit material risk exposures as mentioned in this EC. However, they can achieve the same result through their discretionary authority to alter capital requirements on a bank and through their general formal or informal enforcement actions in the case of threats to safety and soundness.

The assessors discussed with authorities how they used their authority to impose a specific capital charge, and saw clear evidence that this authority is used in practice.

Under the UFIRS, supervisors assess a bank's capital adequacy during every full-scope examination. This assessment is reflected in the Capital component of the CAMELS rating and is an important component of the overall CAMELS composite rating, which also factors into the PCA requirements for banks that are not adequately capitalized (see EC 6).

The RFI/C rating system measures the overall performance and condition of BHCs. The "F" component rates the financial condition of the BHC, which includes an assessment of the adequacy of the BHC's capital. Similarly, the OTS CORE rating system which includes capital, measures the overall performance and condition of SLHCs.

In assessing capital adequacy, the FBAs take into account, among other things, the level and severity of problem and classified assets; exposure to economic declines in capital as a result of interest rate, liquidity, funding, and market risks; the quality and level of earnings; investment, loan portfolio, and other concentrations of credit; certain risks arising from nontraditional activities; the quality of loans and investments; the effectiveness of loan and investment policies; and management's overall ability to monitor and control financial and operating risks, including the risks presented by concentrations of credit and nontraditional activities.

EC 4: The general risk-based capital rule reflects the risk profile of individual banks and BHCs and addresses the on-balance-sheet and off-balance-sheet risks of banks and BHCs. This is done by weighting assets and off-balance-sheet exposures according to their broad inherent risk levels.

Once implemented (for some banks potentially starting in 2011), the advanced approaches final rule for core banks (Basel II) will produce risk-based capital requirements for on- and off-balancesheet items that are more risk sensitive than those produced under the general risk-based capital rule.

The leverage ratio is computed as Tier 1 capital divided by average total consolidated assets, and must exceed a specified level. These leverage ratio requirements do not include off-balance sheet risks.

EC 5: FBAs generally expect and require banks and BHCs to operate at capital levels well above the required minimums (12 CFR Part 3, appendix A (OCC); 12 CFR Parts 208 and 225, appendix $A$ (Federal Reserve) 12 CFR part 325, appendix A (FDIC)). In addition to the risk-based capital requirements, the FBAs regard the leverage ratio requirement as an important element in the capital adequacy regime. It places a constraint on the maximum degree to which a bank or BHC can leverage its equity capital base.

The FBAs understand that the capital rules do not explicitly address all material risks that banks and holding companies may face, particularly in the most sophisticated and competitive financial markets. The general risk-based capital rule has built in "buffers" against these additional risks. The FBAs expect banks and holding companies to have forward-looking capital plans. Assessors saw evidence of supervisors considering capital plans but this work is evolving and being enhanced as a result of recent developments, lessons from the SCAP process, and the move to implement Basel II.

In recognition of the longstanding importance of securitization markets in the U.S., the authorities supplemented Basel I rules with an explicit capital treatment of these exposures, which is similar to 
the Basel II treatment.

Finally, the United States has established PCA requirements, based on trigger levels of capital or leverage ratios. PCA requires the FBAs to place increasingly stringent restrictions on banks as their regulatory capital levels decline. Because of these restrictions, most U.S. banks seek to maintain capital levels at or above the "well capitalized" thresholds, which exceed the capital thresholds specified by the Basel Capital Frameworks. Specifically, to be "well capitalized," a bank must have a total risk-based capital ratio of 10 percent or greater; a Tier 1 risk-based capital ratio of 6 percent or greater; and a leverage ratio of 5 percent or greater. In addition, as a result of the GLB Act, Pub. L. 106-102, BHCs that have elected to be financial holding companies (FHCs, which have broader investment powers) have the incentive to ensure their bank subsidiaries or affiliates remain wellcapitalized (same definitions as PCA) so they can retain their FHC status in order to establish and retain certain non-banking financial subsidiaries and merchant banking investments, not otherwise permitted. BHC's, FHCs, and SLHCs themselves do not have a PCA requirement.

EC 6: Under the PCA statute, 12 USC $\S 1831 o$, the primary FBA for a bank may take a range of mandatory and discretionary actions if that institution's capital falls below the required minimum level for any relevant capital measure. The severity of the supervisory action depends on the severity of the capital shortfall.

Well-capitalized banks are not subject to any specific regulatory restrictions. An adequately capitalized bank may not pay a rate of interest on deposits that is more than 75 basis points over the average rate for that type of deposit in the market in which the deposit is offered. An adequately capitalized bank must also apply for and receive a waiver from the FDIC before it can accept, renew, or rollover brokered deposits. In addition, for adequately capitalized banks, supervisors may take discretionary actions enumerated for undercapitalized banks.

If a bank is undercapitalized, it must, by a certain deadline, submit a capital restoration plan for the primary FBA's approval. Other FBAs, such as the holding company supervisor and the FDIC may be involved in the review. A holding company that controls the bank must guarantee that the bank will comply with the plan in an amount up to 5 percent of the bank's total assets at the time the institution became undercapitalized. Until such time as the primary FBA approves the plan, the bank's asset growth and new lines of business generally are restricted. The FBA may also take other discretionary actions (e.g., formally require recapitalization; direct improvements in management; and restrict transactions with affiliates, interest rates offered, asset growth, and activities).

If a bank is significantly undercapitalized, or is undercapitalized but fails to submit or implement an acceptable capital restoration plan, some of the discretionary actions discussed above become mandatory. In addition, the FBA may require the bank to dismiss officers or directors, divest itself of a risky subsidiary, or be divested by a holding company under certain circumstances. Also, the FBA must approve certain compensation before it can be paid to senior executive officers of the bank.

If a bank is critically undercapitalized, the FDIC generally will restrict the activities of the bank and, at a minimum, the bank must receive the FDIC's approval to engage in certain material transactions. The primary FBA may be required to appoint a receiver or conservator. A comprehensive list of provisions for adequately capitalized, undercapitalized, significantly undercapitalized, and critically undercapitalized banks is available in section 4133.1 of the CBEM and OCC Banking Circular 268. See also 12 CFR Part 565 (OTS).

In addition to being subject to PCA requirements, a bank that fails to meet required capital minimums may become subject to a capital directive under 12 USC $\$ 3907(b)(2)$. Directives are enforceable. Possible remedial measures include an enforcement action, assessment of civil monetary penalties, and/or denial, conditioning, or revocation of corporate applications. A failure to achieve or maintain minimum capital levels also can be the basis for termination of FDIC 


\begin{abstract}
insurance.
While not subject to PCA requirements, holding companies that do not meet the minimum riskbased requirement, or that are otherwise considered to be inadequately capitalized, are expected to develop and implement plans acceptable to the Federal Reserve or OTS for achieving adequate levels of capital within a reasonable period of time. In addition, the Federal Reserve's and OTS's authority to issue capital directives for failing to maintain sufficient capital also extends to holding companies. 12 USC $\$$ 3907(b)(2),3909(BHCS); 12 CFR 565.7 (SLHCs).
\end{abstract}

The assessors discussed with authorities the frequency of use of these instruments and saw evidence of their application in practice.

EC 7: Currently, certain banks can use internal assessments of risk as inputs to the calculation of regulatory capital for market risk and for certain positions in ABCP programs (this results in a 100200 percent risk weight). To be eligible, rigorous qualifying standards must be met and models must be approved. While supervisors could revoke authorizations they are more likely to use alternatives if models do not continue to meet the standards. Use of internal assessment of risk as inputs to capital calculations will become more prevalent with the implementation of the advanced approaches final rule (Basel II).

AC 1: All non-internationally active banks are subject to the Basel I risk-based capital requirements described above. Non-internationally active banks may not be subject to the market risk rule, depending on the size of their trading book exposures (see EC 1). However, as noted above, the definition of Tier 1 capital applying to non-internationally active bank holding companies and SLHCs may include elements that would not be permitted under Basel I rules applying to banks. (see EC 3). As well, as noted in EC 3, the capital requirements for SLHCs are determined on a case-by-case basis. That may or may not be consistent with the applicable Basel requirement in individual circumstances

AC 2: For all banks and BHCs, risk based capital adequacy ratios are calculated and applied in a manner generally consistent with the Basel I requirements as described in EC 1. SLHC capital provisions are as described in EC 2 and are determined on a case-by-case basis. That may or may not be consistent with the applicable Basel requirement in individual circumstances.

AC 3: The FBAs have the power to require corrective action if, in their judgment, a bank's current or prospective capital plan is inadequate and causes it to be in an unsafe or unsound condition. See, for example, 12 CFR 3.10 and the provisions for capital plans under PCA, 12 CFR 6.5. The FBAs expect banks and holding companies to assess their current capital adequacy and future capital needs in a systematic and comprehensive manner in light of their risk profiles and business plans. This requires a forward-looking approach to capital management in which capital levels are set in anticipation of possible changes in events or changes in market conditions that could have an adverse effect.

FBAs evaluate the adequacy of bank and holding company strategic and capital plans. FBAs evaluate internal capital management processes to assess whether they meaningfully tie the identification, monitoring, and evaluation of risk to the determination of the bank or holding company's capital needs (independent of the bank or BHC's risk-based regulatory capital requirements). Banks and holding companies must consider and incorporate internal processes to address risk factors that affect the capital condition, such as overall credit risk exposure; interestrate exposure; liquidity, funding, and market risks; earnings; investment or loan portfolio concentrations; the effectiveness of loan and investment policies; the quality of assets; and management's ability to monitor and control financial and operational risks. See 72 Fed. Reg. 1372 (January 11, 2007) (Interagency Statement on Sound Practices Concerning Elevated Risk Complex Structured Finance Activities) (OCC); SR letter 99-18, Assessing Capital Adequacy in Relation to Risk at Large Banking Organizations and Others with Complex Risk Profile, for example. 


\begin{tabular}{|c|c|}
\hline & $\begin{array}{l}\text { AC 4: The capital adequacy of holding companies is assessed on a top-tier, fully consolidated } \\
\text { basis. Capital ratios also are assessed on a consolidated basis at the subsidiary bank level. } \\
\text { However, there is no calculation of the solo bank capital position, excluding its subsidiaries. The } \\
\text { FBAs expect the distribution of capital among entities within a banking group to reflect the risks } \\
\text { presented by those entities. In addition, each functionally regulated subsidiary of the holding } \\
\text { company is subject to its functional regulator's capital requirements, and those requirements take } \\
\text { into account sector-specific risks. (For example, insurance liability risk is incorporated into the } \\
\text { insurance risk-based capital regime.) Other subsidiaries also are expected to maintain appropriate } \\
\text { levels of capital that are, if applicable, consistent with the expectations of supervisors with } \\
\text { oversight responsibilities. For holding companies in which there is a significant nonbank presence, } \\
\text { capital adequacy is analyzed with particular emphasis on the threat that current or potential issues } \\
\text { present to any affiliated bank or overall financial condition of the enterprise. Supervisors report the } \\
\text { need to go beyond the regular reporting on consolidated capital position of such holding companies } \\
\text { to understand the drivers of their capital position. } \\
\text { SLHC capital is reviewed on a case-by-case basis as described above and savings associations } \\
\text { within the group are required to meet the risk based capital requirements. } \\
\text { AC 5: The FBAs have the statutory authority to establish and enforce minimum capital levels for } \\
\text { individual banks, BHCs, and SLHCs as determined, at the FBAs' discretion, to be necessary or } \\
\text { appropriate for those banks, BHCs, or SLHCs in light of their particular circumstances. These } \\
\text { levels generally exceed minimum regulatory capital requirements. }\end{array}$ \\
\hline Assessment & Largely Compliant \\
\hline Comments & $\begin{array}{l}\text { This CP requires supervisors to set prudent and appropriate minimum capital adequacy } \\
\text { requirements. This is generally true in the U.S., and the U.S. system includes features such as } \\
\text { Prompt Corrective Action requirements that lead banks to hold capital well above the minimums. } \\
\text { However, some important shortcomings exist in the definition of Tier } 1 \text { capital for holding } \\
\text { companies with regard to innovative instruments, in the absence of capital rules for SLHCs and in } \\
\text { allowing certain intangibles to count for a very high portion of bank or thrift Tier } 1 \text { capital. The } \\
\text { exceptions are significant parts of what some banks and BHCs are counting as part of their Tier } 1 \\
\text { capital. The assessment team recognizes the authorities' view that the definition of capital issues } \\
\text { may also be present in other major jurisdictions and that there are issues of competitive equity. The } \\
\text { assessment team also recognizes that some of these matters are being discussed internationally by } \\
\text { the BCBS. } \\
\text { In addition, the failure to put in place formal capital rules for SLHCs, at least for those that are } \\
\text { primarily financial and similar to BHCs, is a significant departure from international core } \\
\text { principles and can allow them in practice to be less well capitalized than international norms or } \\
\text { domestic peers. Allowing SLHC holding companies to publish a calculation described as "Tier } 1 \\
\text { capital" may also mislead investors as to what the regulatory rules and capital position is or suggest } \\
\text { it is a Basel-based measure. } \\
\text { Lastly, while assessors understand the need to not impose undue complexity on smaller or mid-size } \\
\text { banks, the size threshold for applying the market risk rule appears to be at a considerably higher } \\
\text { level than in a range of other countries though FBAs have authority to require banks below the } \\
\text { threshold to apply the market risk rule (and the market risk rule does not currently apply to thrifts). } \\
\text { Authorities should proceed with existing plans to apply the rule for thrifts by the end of } 2010 \text { and } \\
\text { could and should periodically review market risk exposure of selected banks below the threshold to } \\
\text { reconfirm their assessment that the thresholds remain appropriate. }\end{array}$ \\
\hline Principle 7. & $\begin{array}{l}\text { Risk management process. Supervisors must be satisfied that banks and banking groups have in } \\
\text { place a comprehensive risk management process (including board and senior management } \\
\text { oversight) to identify, evaluate, monitor and control or mitigate all material risks and to assess their } \\
\text { overall capital adequacy in relation to their risk profile. These processes should be commensurate } \\
\text { with the size and complexity of the institution. }\end{array}$ \\
\hline Description & EC 1: This criterion applies to requirements on banks and banking groups and responsibilities of \\
\hline
\end{tabular}


the supervisor. They are considered separately in what follows.
Banks and Holding Companies

Banks and holding companies are required to have in place comprehensive risk management policies and processes to identify, evaluate, monitor and control or mitigate material risks. Interagency safety and soundness guidelines require institutions to establish internal controls and information systems that are appropriate to the size of the institution and the nature, scope and risk of its activities. High level requirements are specified in those portions of the interagency safety and soundness guidelines addressing operational and managerial standards. There is detailed guidance and supervisory manuals on various specific risk areas and on consolidated approaches to risk management.

While Basel II is not yet formally the capital calculation, the agencies' Supervisory Guidance on the Supervisory Review Process of Capital Adequacy (Pillar 2) lays out further requirements related to risk management for core banks mandated to use the advanced capital approaches under Basel II, which they have been putting in place for some time. During the implementation process FBAs having been using Basel II implementation (and supervisors have been assessing implementation), among other measures to promote enhanced risk management practices. There are also supervisory letters which lay out additional risk management guidance. Taken together, the amount of guidance on risk management is voluminous.

In assessing the effectiveness of these rules and guidance, assessors met with the FBAs at senior levels, those in charge of supervisory policy and centralized risk assessment, groups of risk specialists, those responsible for on-site and off-site examination and on-site supervisory teams. Assessors also met with a range of major banks and discussed these matters with senior risk, finance, control, infrastructure and compliance executives. Assessors also reviewed recent reports such as those of the Senior Supervisors Group (including the update published in October as the on-site portion of the assessment was in progress), and discussed the conclusions with the authorities and with banks. This included long-time commercial banks, and former investment banks who have recently converted to BHCs.

Risk management cannot be effective if risk monitoring is not adequate. Given the size, complexity and national and global importance of the major banks it is reasonable to expect a high standard of risk monitoring and risk management, including ability for rapid analysis of enterprise-wide risk metrics across products, geographies and counterparties.

Authorities have noted that, in many cases, weaknesses in major firm's risk management systems left them unaware of the aggregate risk exposures on and off their balance sheets. Over the 2007-2009 period, a number of firms, including a number inside and outside the U.S., experienced very material difficulties in integrating credit, market and liquidity risks at the enterprise level and evaluating them jointly in a consistent manner. The assessors took note of observations from senior supervisors that lack of effective firm-wide identification of risk and robust senior management dialogue to evaluate and adjust risk exposures was a contributing factor to those firms that experienced greater difficulties. Banks and FBAs the assessors met with confirmed this observation.

The FBAs have noted that some off-balance-sheet structures were not fully considered due to legal separateness from the bank or holding company itself. Banks chose to support those structures in many cases to maintain investor relationships.

Supervisors and industry groups have highlighted the inadequacy of many firms IT and risk infrastructure in supporting the broad monitoring and management of financial risks. This affected the firms' ability, for example, to consistently value complex products throughout the organizations, estimate counterparty credit risk levels, aggregate exposures quickly to assess concentrations, and perform forward looking stress testing. Some firms report that they had 
material difficulty in identifying the links between various risks (credit risk, counterparty risk, market risk) in stress conditions and did not fully understand the direct as well as indirect exposures to the same underlying risk (e.g., through off balance sheet vehicles and exposures to hedge counterparties such as monoline insurers). For some major firms, the history of mergers made effective, consistent enterprise-wide risk monitoring difficult or impossible for some products. Certain major banks relied on AAA ratings of complex products such as Collateralized Debt Obligations (CDOs) without doing their own risk assessment.

These deficiencies were at the root of major losses and failures or near failures of some major firms. Counterparties and market participants becoming aware of the impact of these deficiencies (e.g., through reporting of material unexpected losses) was a major contributor to loss of market confidence in counterparties and retrenching of effective market operations.

Reports and discussion with FBAs emphasize the need to not underestimate the importance and impact of these weaknesses in amplifying and propagating the crisis.

The assessors discussed with the authorities and with private sector participants that progress has been made in enhancing major banks ability to take an enterprise-wide view of risk. Public reports from supervisors have assessed progress in various areas. These discussions suggest that major banks broadly understand and are committed to the needed improvements. High-level supervisory work by the FBAs, including continuous monitoring, has occurred to assess progress.

However, updates of progress understandably suggest that full remediation will take several years to achieve. Observers, banks and supervisors who assessors talked to confirm the required changes are complex, involve material data-gathering and IT improvements, can involve complex improvements to modeling capabilities and in some cases involve organizational and cultural changes to ensure that risks are not only evaluated based on modeling results but also based on sound judgment.

The result has been material losses on these portfolios and a number of bank failures. As the losses on CRE and other credit exposures continue to be recognized, problems at some smaller and medium size banks will likely continue for some quarters.

Many the assessors met with confirmed that the challenge of complexity for risk management is not limited to larger firms. Smaller and mid-size banks also need a comprehensive view of risksome of them were involved in complex products they did not fully understand. While guidance has been released in several of these areas by the agencies within the past year or so, and further guidance is likely forthcoming in some areas according to the authorities, it is unlikely that all of these risk management deficiencies have been corrected at this stage of the downturn.

Data reviewed by the mission on recent supervisory assessments of these risk areas suggest that issues were not isolated to just a few institutions. However, there are many smaller and mid-size institutions where these risk management weaknesses are not present. There are also some larger institutions which, while needing various improvements, fared materially better than others.

\section{Supervisors}

As part of the examination process, supervisors review and rate risk management to determine the adequacy of bank processes relative to the size and nature of the bank, and identify weaknesses requiring attention from management. If FBAs determine that risk management processes are inadequate, they have the power through various means to require a banking group to strengthen them. However events revealed weaknesses in these processes as well.

Supervisors assess risk management as part of the formal rating systems and various other ratings and assessment processes they use (risk management is a part of Management assessment in the CAMELS rating for banks or part of "R" (risk and risk management) in the RFI/C rating system for BHCs, and the "O" Organizational Structure (inherent risk) and "R" Risk Management for 

SLHCs.
There are continuous supervision activities, specific on-site reviews, and horizontal supervision
reviews. Of-site monitoring looks for indications of metrics that may indicate risk management
issues. Risk-focused supervision places specific emphasis on the quality of risk management.
Examiners consider findings relating to the following elements of a sound risk management
system: active board and senior management oversight; adequate policies, procedures, and limits;
adequate risk measurement, monitoring, and management information systems; and comprehensive
internal controls.

Examiners utilize a risk-focused approach to supervision, and apply flexibility when assessing the appropriateness of a banking organization's risk management processes to address the organization's circumstances and the nature, scope, and complexity of its operations. Large complex banks and holding companies are expected to have far more sophisticated and formal risk management systems in order to address their broader and typically more complex range of financial activities and to provide the board and senior management with the information needed to monitor and direct day-to-day activities.

These risk management systems require frequent monitoring and testing by independent control areas and internal, as well as external, auditors to ensure the integrity of the information used in overseeing compliance with policies and limits. Supervisors will review the adequacy of internal audit work and their capacity to rely on it. Large complex banks and holding companies should have risk management systems or units that are credible, authoritative, and sufficiently independent of the business lines in order to ensure an adequate separation of duties and the avoidance of conflicts of interest. Supervisors review the work of these units, and Basel II supervisory work has also been used in this regard.

For smaller banks engaged predominantly in traditional banking activities and whose senior managers and directors are actively involved in the details of day-to-day operations, risk management systems may be less sophisticated. Even smaller and mid-size banks can have complex parts of their operation needing sophisticated risk monitoring and risk management capabilities. Risk specialists can join supervisory activities for these banks.

Assessors reviewed extensively with FBAs their approach to making these assessments of banks risk management systems and assigning ratings. A banking organization's failure to establish a management structure that adequately identifies, measures, monitors, and controls the risks involved in its various products and lines of business is considered unsafe and unsound conduct. If an agency determines that a bank fails to meet any standard established by the agency or by interagency guidelines, the agency may require the institution to submit an acceptable plan to achieve compliance. See 12 U.S.C. $\$ 1831$-1(e). The agency also has the flexibility to pursue other courses of action, including enforcement actions or less formal actions, given the specific circumstances and severity of an institution's non-compliance with one or more standards.

In the event that an institution fails to submit an acceptable plan within the time allowed by the agency or fails in any material respect to implement an accepted plan, the agency must, by order, require the institution to correct the deficiency. The agency may, and in some cases must, take other supervisory and/or enforcement actions, until the deficiency has been corrected. Assessors discussed with FBAs their approach to using supervisory tools, challenges and lessons learned.

Reports from the authorities, discussion with the authorities and material that the mission reviewed, suggest that there were a number of cases in which banks' weaknesses in aggregating and managing risks on an enterprise-wide basis were not adequately appreciated by supervisors, as they were not by banks. Some other reviews have suggested that deficiencies were identified but in hindsight action was not forceful enough in requiring improvements.

FBAs reported, and assessors viewed, examples of supervisory programs in larger, more-complex 
banks where material complex activities were rated high inherent risk, risk management was rated only satisfactory or weak rather than "strong." Supervisors suggested that their focus was getting "less-than-satisfactory" up to 'satisfactory' (they pointed out that the bar for "strong" is intentionally high).

FBAs discussed with assessors their challenges in integrating their assessments of banks and holding companies' market, credit, and liquidity risk management. They also discussed with assessors their challenges in bringing together a holistic, more-forward-looking view of major banks and holding companies that builds on the bedrock of examination findings, adds offsite analytical and macro perspectives from a wider range of sources in the FBAs and factors in views on systemic vulnerabilities that could influence assessments of risk management at individual banks and holding companies. While there are a variety of concepts under consideration, concrete plans are not in place at the time of the assessment.

The SCAP process was an example of a success in this regard. FBAs are looking to how elements of that process to enhance supervision can be continued. The FBAs most involved in Basel II implementation work currently also reported that Basel II work had promoted the kind of supervisory analysis and inter-agency coordination they wished to emulate in other areas.

Plans for improvements differ among the agencies and the inter-agency component of them is sometimes lacking. FBAs have started to make improvements but acknowledge more work remains. International cooperation in risk assessment of major banking groups is also important. In some cases this work involves systems enhancements at the FBAs that understandably take time to implement.

Banking agencies have instituted specialty skills programs designed to identify and strengthen resources in specialized examination areas.

EC 2: In assessing the adequacy of risk management processes, agencies' processes are designed to ensure that banks and holding companies have appropriate risk management strategies that have been approved by the relevant board of directors. Examiners also verify that the board develops policies and processes for risk-taking, establishes appropriate limits, and that senior management takes the steps necessary to monitor and control all material risks consistent with the approved strategies. The agencies assess, and ratings reflect, the board's fulfillment of its responsibilities primarily in accordance with the guidance outlined in EC 1 above. Agencies note that directors are expected to provide clear guidance regarding the level of exposures acceptable to their organizations and that they have the responsibility to ensure that senior management implements the procedures and controls necessary to comply with adopted policies.

FBAs review material going to boards and are able to discuss matters with individual board members such as the chair of the audit and risk committee.

Published supervisory reviews of weaknesses at major firms note that inability or unwillingness of some boards of directors and senior managers to articulate, measure, manage and adhere to a level of risk acceptable to the firm amounted to a breakdown in risk governance. They also note that some major firms assumed a level of risk well beyond that which the boards understood them to be taking.

The FBAs have noted that weaknesses in executive compensation programs and corporate governance resulted in distorted incentives. At the end of October 2009, during the assessment, guidance from the Federal Reserve was issued regarding banks and BHCs better relating compensation to risk. A horizontal review of practices against this guidance was also announced.

Banks the assessors met confirmed that enhancements in risk governance were underway and assessors discussed the challenges faced by the boards of these institutions. 
EC 3: In assessing the adequacy of risk management processes, agencies ensure that risk management strategies, policies, processes, and limits are properly documented, reviewed and updated, and communicated within the bank and banking group. In addition, examiners determine that exceptions to established policies, processes and limits receive the prompt attention of and authorization by the appropriate level of management and the board where necessary. The agencies generally conduct examinations of the documentation supporting the risk management process and adherence to internal policies, processes, and limits in conjunction with targeted examinations of specific business activities. FBAs' policies and examiner guidance provides that exceptions to policies/limits must be authorized by the appropriate level of management or board.

EC 4: FBAs review whether senior management and the board understand the nature and level of risk being taken by the institution and how this risk relates to adequate capital levels. Examiners also determine that senior management ensures that the risk management policies and processes are appropriate in the light of the institution's risk profile and business plan and that they are implemented effectively. Senior management is expected to regularly review and understand the implications (and limitations) of the risk management information that it receives. The same requirement applies to the board in relation to risk management information presented to it in a format suitable for board oversight.

The agencies assess, and ratings reflect, whether senior management and the board of directors understand the nature and level of risk being taken by the organization primarily in accordance with guidance outlined in EC 1. See Federal Reserve SR Letter 99-18, Assessing Capital Adequacy in Relation to Risk at Large Banking Organizations and Others with Complex Risk Profiles; and OCC's Community Bank Supervision and Large Bank Supervision Handbooks, for example.

FBAs report that recent events have revealed weaknesses in some banks' and holding companies' ability to identify and aggregate risks across the firm and to conduct effective stress testing. For example, some firms relied too heavily on historical correlations or focused too heavily on specific lines of businesses when conducting stress scenarios and thus failed to capture the breadth of their interconnected risk exposures fully. As noted in the overview, the agencies are actively involved in efforts to strengthen enterprise-wide risk management and stress testing practices for large financial organizations.

Several firms the mission met and published supervisory reports suggest at some major firms there was a disparity between the risk firms took and those that the board of directors perceived the firm to be taking. Reports from senior supervisors, and observations the mission made in its meetings with major firms note that firms are undertaking adjustments to increase board and senior executive engagement and to strengthen the resources, stature, and authority of risk management. However it is not yet clear the extent to which these have contributed to stronger risk governance. Boards are also grappling with how they can be effective in setting robust risk appetite statements and monitoring risk, and supervisors are grappling with how to assess this aspect of board performance. While supervisors review material going to boards, and can meet board members collectively and individually, supervisors the mission met report that it is difficult to judge adequacy of board oversight. They also acknowledged their limited capacity in assessing board effectiveness, and indicated that was an area for enhanced focus going forward.

EC 5: FBAs expect banks and bank holding companies to develop internal capital and strategic plans that exceed minimum regulatory capital requirements to ensure that the capital they are holding and forecast to need is adequate given their risk profile. Regulatory capital requirements have limitations in their ability to reflect an organization's full risk profile. (For further information on regulatory capital standards, refer to CP 6) Accordingly, all organizations are expected to understand their underlying risks and hold capital commensurate with those risks-at levels above regulatory minimums-to ensure capital adequacy. See FRB SR Letter 99-18 and AD Letter 08-11, which provides examiner guidance for conducting reviews of compliance with these standards; OCC's Large Bank Supervision and Community Bank Supervision booklets of the Comptroller's Handbook. 
Recent events have highlighted weaknesses in capital standards and firms' own capital planning processes. The agencies are actively involved in the Basel Committee's recent proposals to enhance the Basel II framework for re-securitizations, certain liquidity facilities, and improved value-at-risk models and stress testing. In addition, the agencies recently completed a comprehensive, forward-looking assessment of the financial condition of the nation's 19 largest BHCs to determine what capital buffers would be sufficient for these BHCs to withstand losses and sustain lending even if the economic downturn is more severe than is currently anticipated. The agencies are actively working with those BHCs to ensure that they take appropriate steps to obtain any additional capital needed. As part of this process, holding companies are required to submit capital plans that, among other things, identify steps to address weaknesses, where appropriate, in their internal processes for assessing capital needs and engaging in effective capital planning.

The FBAs have high-level guidance on determining capital adequacy in relation to risk profiles for smaller and mid-sized banks. Examiner guidance and manuals provide high-level guidance to supervisory staff as to how to evaluate capital adequacy based on the institution's risk profile.

EC 6: Banks and holding companies generally are expected to ensure that risk management models and systems are independently validated and tested with an appropriate frequency. The FBAs' supervisory guidance directs that key assumptions, data sources, and procedures utilized in measuring and monitoring risk be appropriate and adequately documented and tested for reliability on an ongoing basis. Models should be independently validated and tested by risk management staff or by internal or outside auditors.

Guidance which more specifically addresses model requirements for various types of models is found in the related sections of the agencies' manuals. (See for example OCC Bulletin 2000-16, Risk Modeling, Model Validation and FRB SR letter 95-51). To address supervisory expectations more comprehensively and explicitly, the Federal Reserve plans to issue enhanced guidance covering supervisory expectations for the validation and testing of risk management models and systems in the near future.

The mission discussed validation issues with the inter-agency team assessing implementation of Basel II and with other supervisors and banks. As in other countries, the robustness of validation procedures is one of the most important issues where continued improvements in banks are required.

EC 7: The FBAs safety and soundness guidelines require banks and holding companies to have information systems that are appropriate to the size of the institutions and the nature, scope and risks of their activities and that provide access to timely and accurate financial, operational, and regulatory reports.

The FBAs assess, and their supervisory ratings reflect, the adequacy of risk management information at both the holding company and institution level. Risk monitoring activities must be supported by information systems that provide senior managers and directors with timely reports clearly indicating positions and risk exposures, as well as with regular and sufficiently detailed reports for line managers engaged in the day-to-day management of the organization's activities. Examiners analyze reports flowing to executive management, board committees, and the board of directors for clarity, consistency, timeliness, quality, and coverage of crucial areas of the organization. Examiners ascertain that reporting is sufficiently comprehensive for sound decision making, and that reports relate risks relative to the bank's earnings and capital.

While the mission saw evidence of these assessments and their effectiveness, as noted previously, for some major firms material inadequacies in IT systems prevented timely aggregation of risk information across portfolios to enable banks to understand their exposures on an enterprise-wide level. While assessors understand that major efforts in banks to rectify these weaknesses are underway, these necessarily take time to design and implement properly. As a consequence, for a 


\begin{tabular}{|c|c|}
\hline & range of major firms it is not possible for supervisors to confirm their effectiveness at this point. \\
\hline Assessment & Materially Non-Compliant \\
\hline Comments & 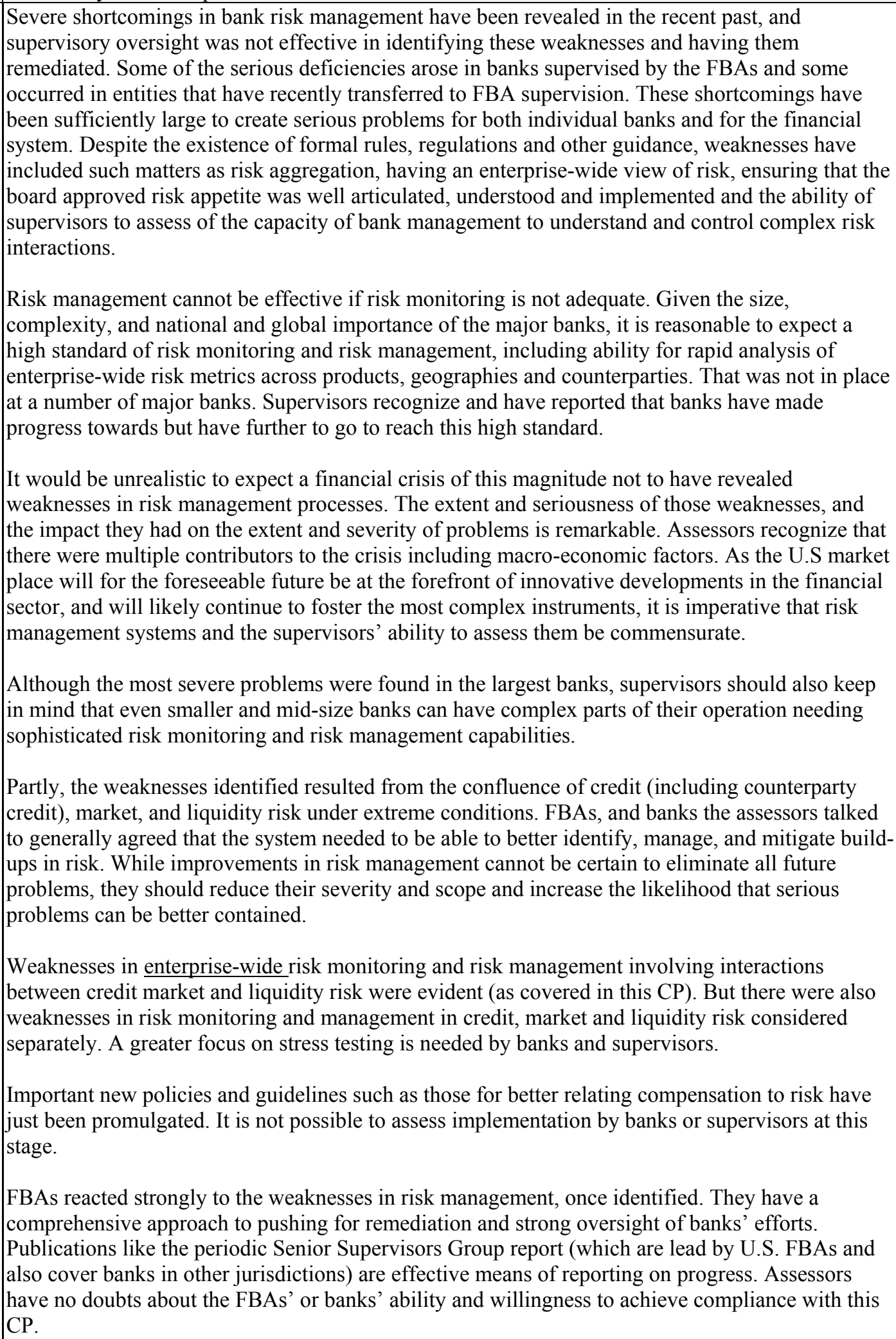 \\
\hline
\end{tabular}




\begin{tabular}{|c|c|}
\hline & $\begin{array}{l}\text { However, these weaknesses have not yet been fully remedied. Challenges in addressing the } \\
\text { hortcomings for banks and supervisors mean that necessary improvements will not be fully in } \\
\text { place for several years. Continued implementation of Basel II for 'core' banks will help reinforce } \\
\text { this process. The improvements will need to be tested by firms in more buoyant conditions which } \\
\text { may challenge the balance between risk and return. Nor have the effectiveness of banks' } \\
\text { improvements been fully tested by supervisors. Given this state of affairs, supervisors will need to } \\
\text { consider what compensating measures, beyond those already in place they may expect firms to } \\
\text { maintain until risk management improvements are more fully embedded. } \\
\text { Supervisors should repeat at regular intervals a horizontal review at major banks assessing } \\
\text { progress, including detailed testing of the robustness of risk monitoring and risk management } \\
\text { improvements. They need to make sure this is broad enough to cover all the large complex banking } \\
\text { organizations. } \\
\text { Supervisors face a challenge in confirming the effectiveness of governance and operation of these } \\
\text { systems at major banks. They need to continue efforts to ensure that they have the quantity and } \\
\text { quality of resources at all levels of their organizations, and the cooperation across agencies and } \\
\text { between parts of their agencies that allows them to meet these challenges. }\end{array}$ \\
\hline Principle 8. & $\begin{array}{l}\text { Credit risk. Supervisors must be satisfied that banks have a credit risk management process that } \\
\text { takes into account the risk profile of the institution, with prudent policies and processes to identify, } \\
\text { measure, monitor and control credit risk (including counterparty risk). This would include the } \\
\text { granting of loans and making of investments, the evaluation of the quality of such loans and } \\
\text { investments, and the ongoing management of the loan and investment portfolios. }\end{array}$ \\
\hline Description & 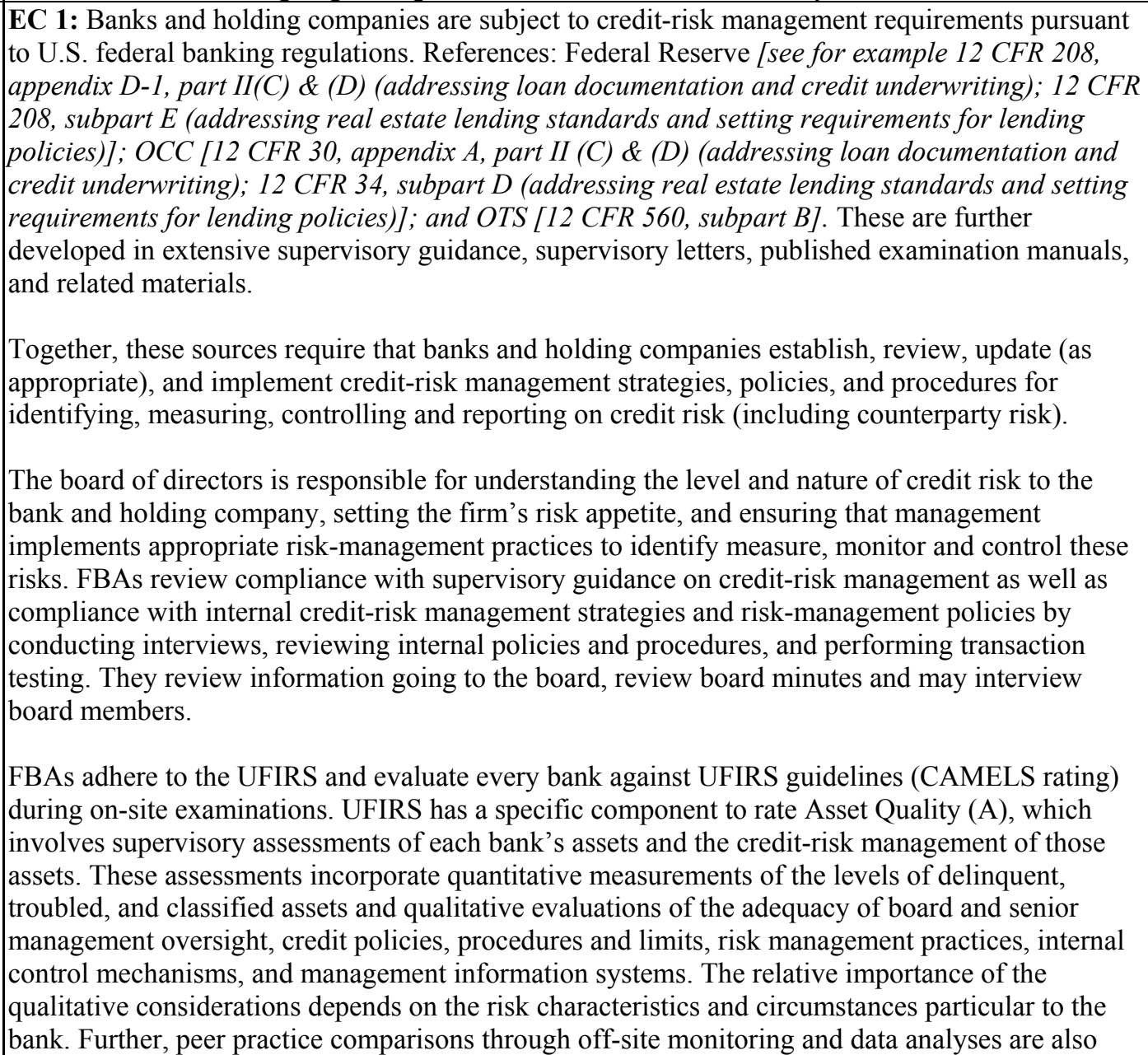 \\
\hline
\end{tabular}


integral parts of the evaluation process and, when available and relevant, may be used in assigning a rating.

Recent published reports on the crisis, and major banks that the assessors met, have noted the difficulties for boards in complex institutions to understand and oversee risk and set and monitor risk appetite statements. In certain cases, risks assumed by banks were beyond that which the boards understood them to be assuming.

Supervisors assess the performance of the board during continuous onsite supervision at larger banks, through onsite reviews at smaller and mid-size banks and through board components of horizontal reviews. Typically this involves review of material going to the board and review of board minutes. Occasionally supervisors will observe a board meeting in person. At larger banks and holding companies supervisors will also meet with key board members such as chairs of key committees.

EC 2: FBAs generally expect that the banks' and holding companies' policies and processes for managing credit risk will establish an appropriate and properly controlled credit-risk environment. FBAs expectations are enumerated in supervisory guidance and generally include the features listed in this EC. As per supervisory letters, bulletins and manuals, supervisors are expected to consider a wide range of criteria including such matters as:

- comprehensiveness and relevance of policies to a banks' strategies,

- $\quad$ polices regarding approval of new credit products, credit administration practices including the quality of borrower and counterparty analyses adequate documentation, accuracy of the risk rating system,

- $\quad$ linkage of that to management decision making, and effectiveness of individual credit, business level or portfolio level stress processes, including for credit concentrations, and

- $\quad$ MIS systems, policies and procedures for problem loan management, clear identification of portfolio business risks, appropriate limit structures and handling of exceptions, and adequate risk management practices with respect to third party (indirect) originations.

Agency expectations for each of the components will vary with the size and complexity of the bank or holding company. There are various longstanding processes to assess credit risk policies and processes. These are reviewed directly as part of the exam process, as is the ability to rely on loan review work by internal audit and any of their findings. Examiners review selection of loan exposures for the appropriateness of the classification and the loan loss estimates. The shared national credit program is an extensive, annual inter-agency process that reviews a wide range of syndicated loans for the accuracy of the assigned risk rating. This helps determine provisions at individual banks for these loans and helps ensure consistency of ratings across firms and agencies. A higher proportion of syndicated credits needing adjustments at a bank is an indicator of problems in that bank. FBAs have various off-site tools to assess credit quality and identify outliers on such measures as concentrations. Horizontal reviews for groups of institutions may be performed. Continuous monitoring at large banks will focus on metrics of trends in credit quality and look for evidence of how the credit risk management process is operating in practice.

During the recent period, there is broad agreement among banks, supervisors and other commentators that there was a material and widespread erosion in underwriting standards for residential mortgages in across the spectrum of banks, non-bank affiliates and among non-bank lenders. The decline in underwriting standards also affected commercial real estate and other asset categories such as C\&I credits and leveraged loans (shared national credit data for loans written in 2006 and 2007 identifies this weaknesses).

For residential mortgages, this decline resulted from a variety of influences, including belief in the ability to package and distribute loans, practices of unregulated mortgage brokers and other entities, and belief in the unlikelihood of sustained house price declines following years of growth and abundant liquidity. Behavior of GSE's and other federal policies, such as affordable housing 
goals, to encourage home lending are viewed as playing a part. The build-up of risks from one year to the next over the previous decade was steady and the regular pace of the build-up may have lulled market participants and banks into a false sense of security.

There were also, for example, steady increases in concentrations of CRE amongst smaller and midsize banks in the decade preceding the crisis. For example, data reviewed by the assessors at several agencies showed that the proportion of banks with concentrations of CRE at 300 percent, 400 percent or 500 percent or more of capital had roughly doubled from their lows in 1996 to 2002/03. By such measures, concentrations were materially higher than their previous peak. They then further increased more moderately in the next few years.

Interagency guidance did not set limits on CRE concentrations but the guidance did set 300 percent as a high-level indication of potential CRE concentration risk and indicated banks warranting intensive supervisory oversight. (A statute limits the aggregate amount of commercial loans made by federal savings associations to 20 percent of total assets, and amounts in excess of 10 percent may be used only for small business loans. 12 U.S.C. § 1464(c)(2)(A).)

A number of the issues affecting the weakness in lending standards occurred in unregulated entities, but they also occurred in non-bank affiliates of major banks. Supervisors that the assessors met agreed that non-bank affiliates of certain major banks accepted risks the banks would not have taken. Under the U.S. system, these entities are often not regulated by a functional bank regulator but fall under the holding company. For the regulator of the bank, the issue is the extent to which supervision of the bank identifies and takes account of developments outside that could affect the bank. For the holding company regulator, the issue is the extent of supervisory involvement in nonbank affiliate issues in assessing the strength of the consolidated entity. And, as noted below and further in BCP 24, there are current statutory limitations to what the holding company supervisor may review at non-bank affiliates.

As noted in CP 24, the legislative framework suggests FBAs focus on the bank or holding company and defer to some degree on functional supervisors. Discussions with FBAs suggest this signal may have lead supervisors not to focus sufficiently on inappropriate credit risk activities in non-bank affiliates.

Many acknowledge that banks of all sizes needed to look more closely at potential credit (or market) risk in off-balance-sheet entities, and more attention on credit risk in non-bank affiliates is needed. Supervisors, and representatives of bankers that the mission met, acknowledged that a range of institutions had not demonstrated risk management practices commensurate with the risks they were assuming.

While other factors in the originate-to-distribute model for sub-prime mortgages and Commercial Mortgage Backed Securities (CMBS) for example were problematic, the foundation of certain of these structures on inadequately underwritten mortgage exposures was a major contributor to the problems that subsequently arose.

At various places in the FBAs, at least some of the increased credit risk was seen and appreciated. In the period 2005-2007, agencies issued guidance in such areas as home equity lending (May 2005) sub-prime and non-traditional mortgage lending (Oct. 2006) and commercial real estate concentrations (Jan 2007). In some cases this was well after the increased risk was identified. Certain of the FBAs conducted horizontal reviews at midsize and community banks to reinforce implementation of the guidance. FBAs reported delays in finalizing guidance in some areas such as CRE concentrations because of interagency differences in views about the approach to follow and strong resistance from industry in some areas during the comment period.

A range of FBA staff that the assessors talked to agree that by this time, however, a material part of the weaker underwritten credits and loan concentrations were already on banks' books. FBAs also discussed with assessors the difficulty they had in dealing with weak credit risk management 
practices at banks in advance of serious problems emerging. This was due to such factors as supervisors operating in a period where actual losses observed were very low, and the incurred loss accounting model for loan losses. This created difficulties for examiners in getting banks to put up a reasonable allowance for loan losses in the face of resistance from the banks, and auditor requirements. Others the assessors met emphasized the contribution from other aspects of the accounting rules such as the requirement for valuing securities held by banks on an "exit price" rather than on an estimate of what willing buyers and sellers would likely transact.

Reports and discussion the assessors had with FBAs note that banks and FBAs appeared to have underestimated or not understood the risks in complex credit products at larger banks, the warehousing risk in the originate to distribute model, and risks arising from the opaqueness of structures based on sub-prime lending or leveraged loans, and issues in traded credit risk products as well as the convergence and speed of the risks. Some of these apparent credit risk issues were on products that were part of the MTM books and/or on policies and procedures around credit risk trading. The assessment of these matters is included in CP 13.

Stress testing guidance exists but practices appear to need improvement in severity and in taking account of portfolio level impacts of credit risk events that can affect banks in a variety of direct and indirect ways. While many smaller and mid-size banks do some form of simple "what if" analysis, FBAs that the assessors talked to indicate more-formalized stress analysis would be helpful. In large banks, the recent SCAP exercise conducted by the FBAs is a notable example of the agencies' increased use of stress testing.

In some cases, too much reliance was placed by banks and supervisors on ratings for products where that rating proved to be inappropriate for the true measurement of credit risk.

Certain of the FBAs are developing and enhancing their off-site and on-site tools and approaches to allow more comprehensive monitoring, supervisory credit portfolio stress testing and identification of outliers. In some cases, lack of a coordinated approach appears due to the difficulties of multiagency coordination.

EC 3: The statutes on transactions with related parties, discussed under CP 11, require credit decisions to be made free of conflicts of interest, and on an arm's length basis. Only above a certain amount are credit decisions required to be made by the board without participation of the interested party. Terms must be in accordance with those offered to members of the general public. Compliance is reviewed as part of the normal supervisory process including transaction testing, and through reliance on internal control functions whose effectiveness is tested from time to time by FBAs. Issues in related party lending are not viewed by the FBAs as major contributors to the recent turmoil.

EC 4: Under the FBAs' statutory examination authority, supervisors may review all books and records maintained by a bank (and its affiliates) subject to the agencies' supervision. Supervisors are given full access to this information, and to all employees involved in assuming, managing, controlling and reporting on credit risk, during examinations. Banks and holding companies that do not supply requested information or access to premises and personnel may be subject to supervisory sanctions and prosecution.

AC 1: FBAs review policies and procedures to ensure that banks establish limits on their credit exposures and that limits and approval authorities are clearly defined. Supervisors ensure that credit policies describe the manner in which exposures will be approved and ultimately reported to the board. Under general principles for sound credit risk management, supervisors expect that major credit beyond a certain size be decided by senior management. They also expect those that are new products or not in line with mainstream activities to receive more senior and more formal attention, in line with the size and complexity of the bank.

AC 2: Banks and holding companies are expected to implement policies and processes to identify, 


\begin{tabular}{|c|c|}
\hline & $\begin{array}{l}\text { measure, monitor, and control counterparty credit-risk exposure, including potential future } \\
\text { exposure sufficient to capture the material risks inherent in individual products or transactions. The } \\
\text { expectations for these policies and processes are described in supervisory guidance. During the } \\
\text { course of examinations, supervisors review compliance with the guidance. To adequately evaluate } \\
\text { these factors, supervisors conduct sufficient and targeted transaction testing on activities, business } \\
\text { lines, and products experiencing significant growth, above normal profitability or large potential } \\
\text { future exposures. } \\
\text { As part of transaction testing, supervisors review potential future exposure calculations to } \\
\text { determine whether they reflect realistic measures of exposure in both normal and stressed markets } \\
\text { and whether banks and holding companies need to enhance their methodologies. Supervisors also } \\
\text { determine whether methodologies employed to measure exposures are applied across all products } \\
\text { and whether appropriate management information systems are in place for counterparty credit-risk } \\
\text { limits and monitoring. While there were some weaknesses in these processes revealed by the } \\
\text { stressed market conditions these were not the root cause of major problems. Underlying causes of } \\
\text { the weaknesses in counterparty credit risks are addressed in CP } 7 \text { (risk management) and CP } 13 \\
\text { (market risk). } \\
\text { AC 3: There are no specific requirements of guidance on banks' monitoring the total indebtedness } \\
\text { of entities to which they extend credit. However, bank practice is to do this as a part of their credit } \\
\text { granting process. And, supervisors review how a bank monitors the total indebtedness during their } \\
\text { review of overall credit risk management. }\end{array}$ \\
\hline Assessment & Largely Compliant \\
\hline Comments & 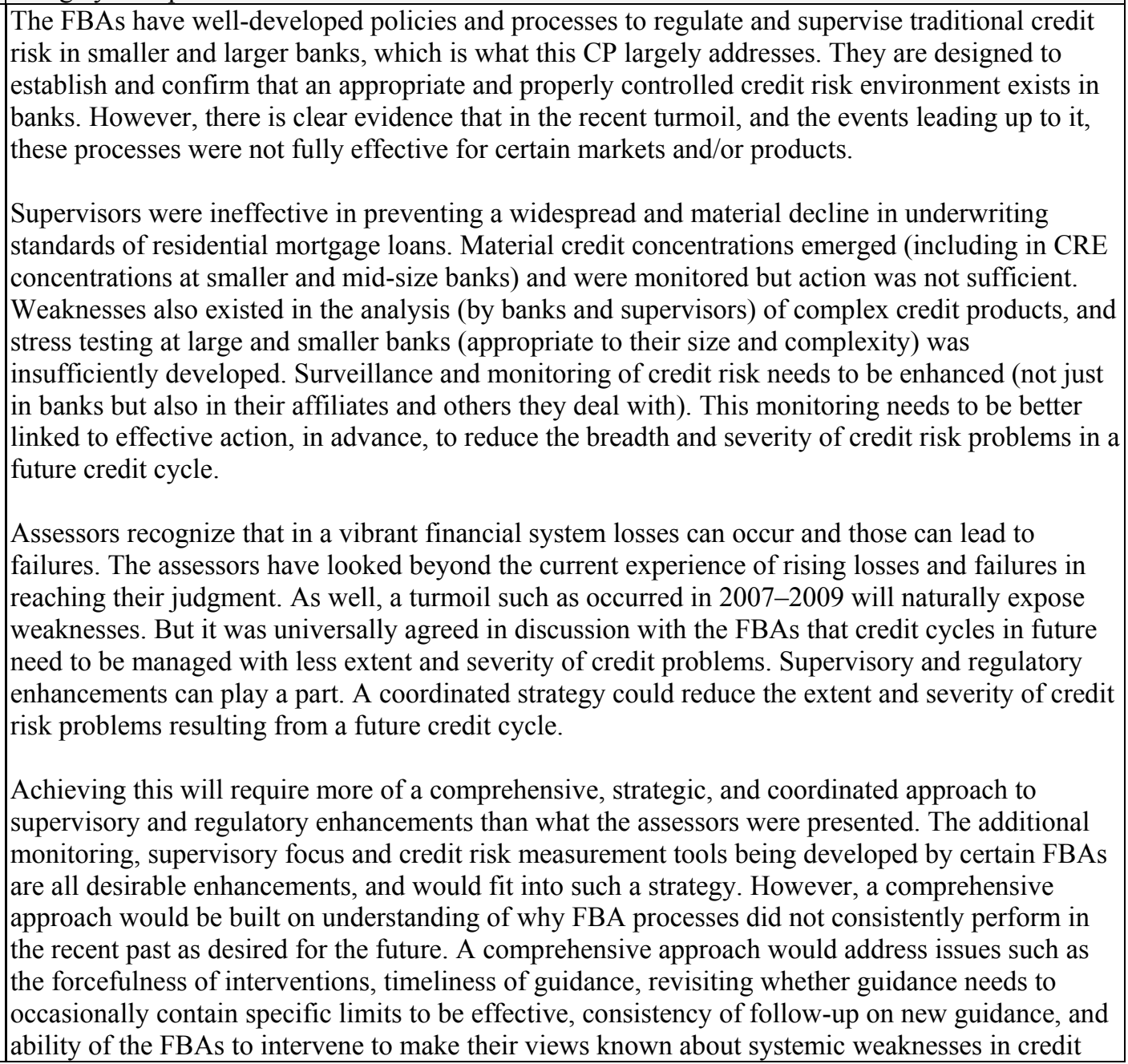 \\
\hline
\end{tabular}




\begin{tabular}{|c|c|}
\hline & 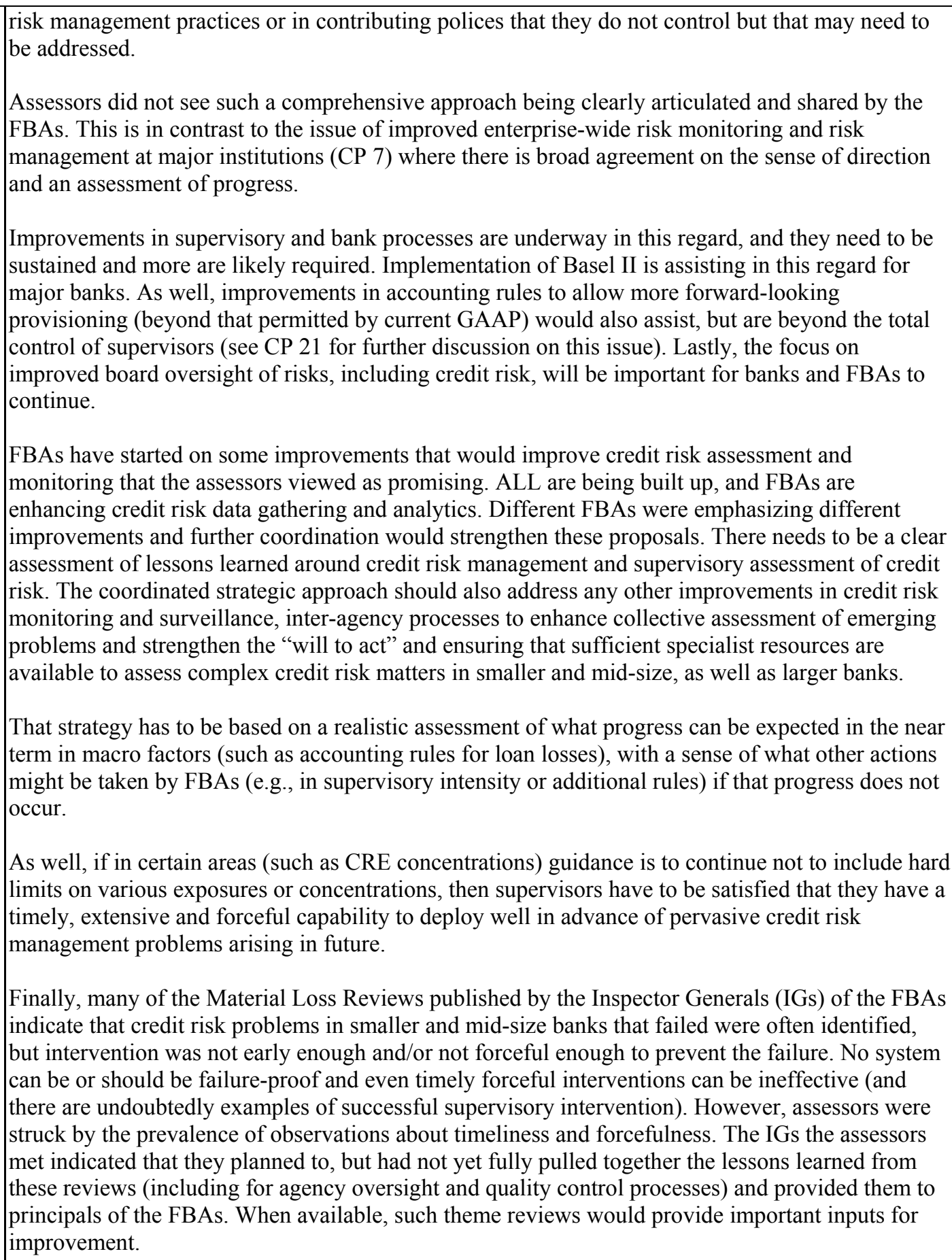 \\
\hline Principle 9. & $\begin{array}{l}\text { Problem assets, provisions and reserves. Supervisors must be satisfied that banks establish and } \\
\text { adhere to adequate policies and processes for managing problem assets and evaluating the } \\
\text { adequacy of provisions and reserves. }\end{array}$ \\
\hline Description & $\begin{array}{l}\text { EC 1: The safety-and-soundness provision of the FDI Act (FDI Act), (12 U.S.C. } \S 1831 p-1(b)) \\
\text { requires the FBAs to establish standards related to asset quality. The interagency safety-and- } \\
\text { soundness guidelines implementing this provision require a bank to establish and maintain a } \\
\text { system to identify problem assets and prevent deterioration in those assets. The system should be } \\
\text { commensurate with the bank's size and the nature and scope of its operations. In addition, the bank } \\
\text { is expected to (a) conduct periodic asset quality reviews to identify problem assets; (b) estimate the }\end{array}$ \\
\hline
\end{tabular}


inherent losses in those assets and establish allowances/reserves that are sufficient to absorb estimated losses; (c) compare problem asset totals to capital; (d) take appropriate corrective action to resolve problem assets; (e) consider the size and potential risks of material asset concentrations; and (e) provide periodic asset reports with adequate information for management and the board of directors to assess the level of asset risk.

U.S. federal law provides that the accounting principles applicable to reports or statements required to be filed with FBAs generally must be uniform and consistent with U.S. generally accepted accounting principles (U.S. GAAP). In certain situations, the FBAs can prescribe alternate accounting principles, provided the alternate principles are "no less stringent" than U.S. GAAP. FBAs report prescriptions are very infrequent.

U.S. GAAP includes guidance on accounting for impairment in a loan portfolio and other credit exposures. (See Statement of Financial Accounting Standards No. 5, Accounting for Contingencies (Financial Accounting Standards (FAS) 5), and Statement of FAS No. 114, Accounting by Creditors for Impairment of a Loan (FAS 114)). This covers assets at an individual level and a portfolio level for credits with homogeneous characteristics. The FBAs have issued and, as warranted, periodically updated interagency policy statements on the Allowance for Loan and Lease Losses (ALLL), addressing the supervisory expectations about supervised banks' application of and documentation supporting FAS 5 and 114 to bank credit portfolios.

These policy statements elaborate on the asset quality obligations, noted above, set forth in the interagency safety-and-soundness guidelines. These include, among other matters (a) the responsibilities of boards of directors, management, and supervisors of banks regarding the ALLL; (b) factors to be considered in the estimation of the ALLL; and (c) and the objectives and elements of an effective loan review system, including a sound credit-grading system. The statement emphasizes that each bank is responsible for developing, maintaining, and documenting a comprehensive, systematic, and consistently applied process for determining the amounts of the ALLL and the provision for loan and lease losses.

To fulfill this responsibility, each bank is expected to ensure that controls are in place to consistently determine the ALLL in accordance with U.S. GAAP, stated policies and procedures, management's best judgment, and relevant supervisory guidance. This Interagency Statement on the ALLL identifies losses that are to be estimated in accordance with FAS 5, including credit losses in off-balance-sheet credit exposures, resulting from commitments and explicit and implicit recourse. Separate interagency guidance addresses the appropriate accounting and reporting treatment for certain loans that are sold directly from the loan portfolio or transferred to a held-forsale account. Both the Federal Reserve and the OTS expect holding companies to follow the Interagency Statement noted above and review this during examinations of holding companies.

The FBAs also expect banks and holding companies to perform reasonable stress tests to identify possible events or changes in markets that could have serious adverse effects in the future. The assessors formed the impression in various discussions that there was room to improve the coherence and use of stress/scenario testing and its link to bank's decision making.

In October 2009 the FBAs issued updated guidance on prudent commercial loan workouts.

EC 2: The FBAs review the adequacy of a bank's loan classification, loss provisioning process, and overall capital adequacy during each supervisory cycle. In assigning a component rating for assets, supervisors consider the adequacy of the bank's ALLL and other asset valuation reserves as well as the adequacy of the its credit administration practices. Supervisors review the policies, procedures, and internal controls for classification of, and provisioning for, credit risk as well as compliance with laws and regulations.

To support this assessment, supervisors generally conduct transaction testing to assess the effectiveness of these internal control processes. In reviewing a sample of loans they assign them to 
categories (pass, special mention, sub-standard, doubtful and loss, and compare to the bank's classification. This can result in supervisory recommendations for additional provisions.

Supervisors also review the internal and external audit reports, internal management reports, models, and model validation processes to determine that classifications and provisioning provide boards of directors and senior management an accurate and timely picture of the bank's or holding company's credit risks. The agencies' respective examination manuals contain detailed procedures that supervisors follow in conducting their reviews.

The assessors reviewed this process with supervisory staff, reviewed samples of monitoring reports the agencies used, and saw evidence of it working in practice.

Through the agencies' Shared National Credit Program' (SNC), teams of supervisors from the agencies conduct an annual review of the classification of large syndicated loans held by multiple banks and holding companies. These reviews are conducted on-site at agent/lead banks and holding companies with assigned classifications applicable to all participating institutions. The 2009 review covered 8,900 credit facilities with commitments totaling US $\$ 2.9$ trillion. Credits held by banks and non-banks are included. The review found credit quality deteriorating to record levels. Underwriting standards in 2008 improved from previous years but there were loans with structurally weak underwriting characteristics initiated pre mid-2007 that contributed to the increase in 2009 in criticized assets (sub-standard, doubtful and loss). Leverage finance credits represented more than 40 percent of the value of criticized credits.

There was clear evidence of this longstanding SNC process being effective in identifying problem assets, ensuring consistency of treatment of those assets among banks. It also is effective in identifying banks where SNC experience suggested their processes for identification of problem assets needed improvement.

EC 3: Pursuant to the FDI Act, 12 U.S.C. $\S 183 \ln (a)(3)(C)$, all assets and liabilities, including contingent assets and liabilities, of banks and holding companies must be reported in, or otherwise taken into account in the preparation of, any balance sheet, financial statement, report of condition, or other report required to be filed with a FBA. Implementing supervisory guidance makes clear that systems for classification and provisioning should take into account off-balance-sheet exposures.

The Interagency Statement on the ALLL requires the recognition of credit losses in off-balancesheet exposures, including loan commitments, standby letters of credit, guarantees, and recourse liabilities on loan transfers. U.S. FBAs assess the structure of off-balance-sheet instruments to understand the explicit and implicit credit risk to the bank.

EC 4: In accordance with long standing supervisory guidance the FBAs confirm that banks and holding companies evaluate the ALLL reported on the balance sheet as of the end of each quarter, or more frequently if warranted. The determination of the ALLL and the necessary provision are to be based on the bank's current judgments about the credit quality of the loan portfolio, and should consider all known relevant internal and external factors that affect loan collectability as of the evaluation date. ALLL estimates are expected to reflect rigorous quantitative analyses supplemented by management judgment.

The assessors also noted that, from time to time, agencies may issue supplementary guidance for particular products or markets emphasizing the important of realistic repayment and recovery expectations, including examples of what that means in practice for that product or market. Discussion the assessors conducted showed agencies understand the importance of this issue in the current downturn.

EC 5: Under the supervisory guidance, banks and holding companies are expected to have appropriate policies and processes, and organizational resources for the early identification of deteriorating assets, for ongoing oversight of problem assets, and for collecting on past-due 
obligations. The FBAs require banks and holding companies to initiate additional or heightened oversight as the rating for a credit exposure deteriorates and to initiate appropriate corrective action, including potential escalation into the restructuring, foreclosure, or collection processes.

Based on a combination of on-site examinations and off-site monitoring, FBAs assess the quality and timeliness of the bank's or holding company's rating system, classification process, and credit workout processes to determine if they are appropriate. Supervisors also assess the trend in credit ratings migration and may direct a bank or holding company to re-grade any credit where the rating does not reflect the credit's actual condition.

The assessors discussed the operation of this processes in the current environment and saw examples of its operations. At the time of the assessment impairments and the ALLL were rising considerably across the banking system particularly for mortgage loans, leverage loans, commercial real estate exposures and C\&I loans. The assessors discussed with authorities the challenges that supervisors of smaller and mid-size banks have faced in ensuring management at banks recognized impairments after the previous long period of negligible loan losses.

Examples reviewed by the mission demonstrated the authorities' willingness to use enforcement tools as necessary when provisioning processes and practices are inappropriate and safety and soundness is threatened. Nonetheless, all FBAs reported on the difficulties they can face in ensuring timely provisioning in individual circumstances under the current accounting model which looks to identify losses that have been "incurred" in the portfolio (see CP 22).

EC 6: Under the FBAs' statutory examination authority, supervisors may review all books and records maintained by a bank or holding company (and its affiliates) subject to the agencies' supervision. During the course of examinations, supervisors are provided with full access to all records and employees of the bank or holding company. This includes access to individual loan files, risk-management reports, internal and external audit reports and other material (such as board or committee minutes and reports). Banks and holding companies that do not supply requested information or access to premises and personnel are subject to supervisory sanctions and prosecution. Authorities indicated that access to information on credit classification and provisioning is not an issue.

EC 7: If provisions are deemed to be inadequate, the FBAs will seek to employ corrective measures. In any case, the FBAs have the authority to require additional provisions or to impose other remedial measures. See generally 12U.S.C. $\S 1818($ b). When a bank's or holding company's ALLL is inadequate, supervisors will require it to adjust its ALLL by an amount sufficient to bring the ALLL reported on its regulatory reports to an appropriate level as of the evaluation date, subject to the constraints imposed by accounting standards. This adjustment should be reflected in the current period provision or through the restatement of prior period provisions, as appropriate for the circumstance. (See Interagency Statement on the ALLL). The FBAs can also require the addition of capital or an adjustment of capital to reflect the insufficient levels of provisions and ALLL.

The mission saw ample examples of this process operating in practice in the current environment.

EC 8: The FBAs have the authority to require additional provisions or to impose other remedial measures. Assessment of the loan classification system and the adequacy of provisions is part of every full scope examination (annually or every 18 months). Various authorities have also conducted horizontal exams for certain banks or portfolios that focus on loan classification and provisioning practices. If the supervisor concludes that the reported ALLL level is not appropriate or determines that the ALLL evaluation process is based on the results of an unreliable loan review system or is otherwise deficient, supervisors will require the bank or holding company to adjust the ALLL and address the process deficiencies.

Off site activities include a variety of monitoring techniques related to groups of individual 
institutions, peer comparisons, comparisons against benchmarks, and summary statistics (see CP 20 for further description).

EC 9: FBAs expect banks and holding companies to establish and implement appropriate policies and procedures for periodically assessing the value of risk mitigants, including guarantees and collateral, at net realizable value. For real estate based credits, the agencies have appraisal and real estate lending standards regulations that govern collateral valuation practices, underwriting standards (e.g., loan-to-value limits), credit administration, and portfolio management expectations.

EC 10: Pursuant to the safety-and-soundness provision of the FDI Act, (12 U.S.C. $\S 1831 p-1(b)$,) the FBAs have established criteria for identifying an asset as "impaired." (See Interagency Statement on the ALLL. The accounting guidance defines impaired assets in several pronouncements - individual loans under FAS 114 and loans assessed collectively (as part of a pool) under FAS 5.

Banks and holding companies have the discretion to determine which individual loans are considered for evaluation of impairment under FAS 114 and define them in their internal accounting documents. Fundamentally, an impaired loan is defined as a loan where management does not think that it will collect payment in full of contractual interest, fees, and principal payments.

The amount of impairment for a pool of loans is based on a bank's or holding company's ongoing loan review process and analysis of loan performance. One method of estimating loan losses for groups of loans is through the application of loss rates to the groups' aggregate loan balances. Such loss rates typically reflect the bank's or holding company's historical loan loss experience for each group of loans, adjusted for relevant environmental factors (e.g., industry, geographical, economic, and political factors) and current conditions over a defined period of time.

EC 11: Under the various guidance banks and holding companies should have policies and procedures in place to ensure that the board of directors receives timely and appropriate information on the condition of the bank's or holding company's asset portfolio, including classification of credits, the level of provisioning, and major problem assets.

Agency supervisors determine whether bank management provides clear, concise, and timely information about the loan portfolio and its attendant risks to the board of directors. Supervisors determine that management has clearly communicated strategic objectives and risk limits to the board and that the board has approved them. Supervisors also ensure that risk levels, trends, provisioning levels, significant problem assets, policy exceptions, and compliance with laws and regulations are adequately reported to both senior management and the board. Supervisors determine whether the reports' descriptions of loan portfolio risks are sufficient to enable the board to exercise its supervisory responsibilities. The agencies expect that a unit independent of the lending function will periodically evaluate the accuracy, completeness, and timeliness of the information in these reports.

EC 12: Pursuant to the Interagency Statement on the ALLL, banks are expected to value, classify, and allocate provisions for large exposures on an individual item basis.

AC 1: Supervisors have issued specific supervisory classification for retail credits, (see "Uniform Retail Credit Classification and Account Management Policy"; 65 Fed. Reg. 36903 (June 12, 2000)). Under these guidelines, banks and holding companies are expected to classify loans and recognize losses when payments are contractually a minimum number of days in arrears. For personal loans these are: 90 days substandard; 120 days before write off. For credit cards these are 90 days sub-standard and 180 days before write-off.

For loans not covered by the policy on retail credit the FBAs consider credit risk factors beyond just arrearage. Credits are required to be classified when well defined weaknesses that jeopardize 


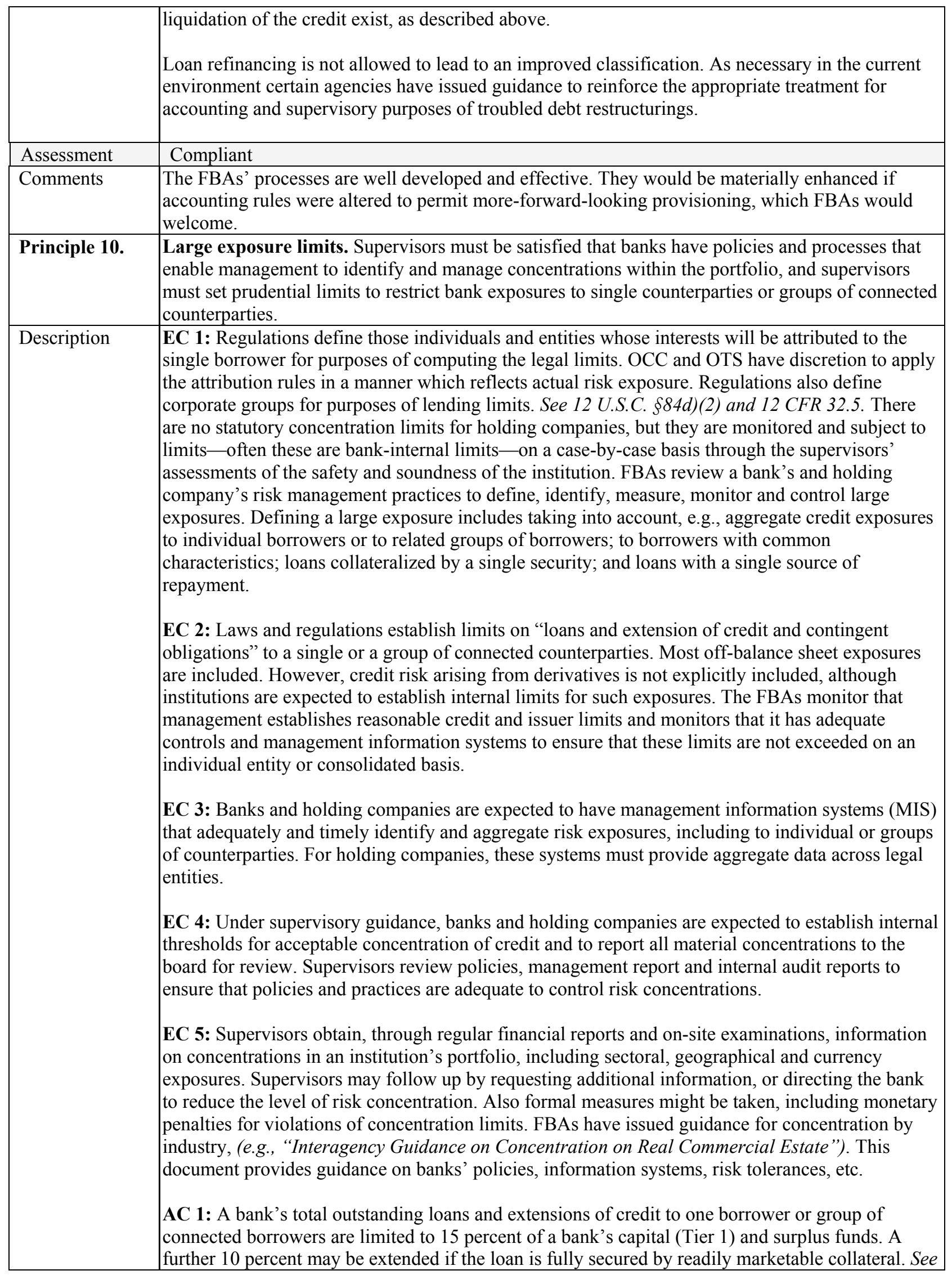




\begin{tabular}{|c|c|}
\hline & $\begin{array}{l}12 \text { U.S.C. } \$ 84 \text {. A bank may not loan more than } 50 \text { percent of its Tier I capital and surplus funds to } \\
\text { a corporate group, even if for some reason, the whole group would not be judged to be "connected" } \\
\text { in which case the } 15 \text { percent limit would apply. The } 50 \text { percent limit is rarely applied. A typical } \\
\text { situation would be when a bank makes loans to companies that are related through common control } \\
\text { but where the companies are financially independent. Additionally, there are separate limits, } 10 \text { to } \\
25 \text { percent of the capital and surplus funds depending on the type of security and/or obligor, on the } \\
\text { amount of securities issued by any one obligor that can be held by one bank. }\end{array}$ \\
\hline Assessment & Compliant \\
\hline Comments & $\begin{array}{l}\text { There exist various reporting requirements to the FBAs on large exposures, such as for banks under } \\
\text { the Shared National Credit Program and for the largest } 10 \text { U.S. banks. In order to increase the focus } \\
\text { on risk concentrations and to facilitate peer reviews, harmonized reports from all banks on large } \\
\text { exposures, e.g., the } 20 \text { largest exposures/and all exposures exceeding a certain threshold such as } \\
10 \text { percent of own funds, should be provided to bank management and board and to the supervisors } \\
\text { on a regular basis, such as quarterly. In the reports, a "large exposure" should be defined to include } \\
\text { credits, asset holdings, and other on-balance and off-balance commitments in order to provide a } \\
\text { complete picture. } \\
\text { The thresholds for large exposures mentioned under AC1 above are higher, i.e., allow for greater } \\
\text { risk concentration, than international best practices, which would be } 25 \text { percent of capital funds for } \\
\text { all aggregated exposures to a single counterparty, including credits as well as other exposures such } \\
\text { as security holdings. In the present U.S. rules, limits for security holdings are separate and } \\
\text { additional to those for credits. This opens the possibility for excessive risk concentrations. Hence, } \\
\text { while the assessors find the present division of the } 15 \text { and } 10 \text { percent limits (see AC } 1 \text { above) to be } \\
\text { a sound practice, they recommend that the additional exposures which a bank can hold in relation } \\
\text { to the same counterpart in the form of issued securities be included in the } 15 \text { plus } 10 \text { limits. } \\
\text { Supervisory reporting and monitoring large exposures on a sectoral basis, e.g., for CRE exposures } \\
\text { are being assessed in CP } 7 \text { which deals with credit risk and credit risk management. }\end{array}$ \\
\hline Principle 11. & $\begin{array}{l}\text { Exposures to related parties. In order to prevent abuses arising from exposures (both on balance } \\
\text { sheet and off balance sheet) to related parties and to address conflict of interest, supervisors must } \\
\text { have in place requirements that banks extend exposures to related companies and individuals on an } \\
\text { arm's length basis; these exposures are effectively monitored; appropriate steps are taken to control } \\
\text { or mitigate the risks; and write-offs of such exposures are made according to standard policies and } \\
\text { processes. }\end{array}$ \\
\hline Description & $\begin{array}{l}\text { EC 1: Two major sets of laws, applicable to insured depository institutions, define and establish } \\
\text { limits on transactions with "related parties." First, sections } 23 \text { A and 23B of the Federal Reserve } \\
\text { Act are designed to prevent the misuse of an institution's resources through transactions with its } \\
\text { affiliates, including loans, asset purchases and guarantees. Section 23A imposes quantitative and } \\
\text { collateral requirements on transactions covered by the Act. Second, sections } 22(\mathrm{~g}) \text { and } 22(\mathrm{~h}) \text { of the } \\
\text { Federal Reserve Act impose a number of restrictions on extensions of credit between an insured } \\
\text { depository institution and its insiders and their controlled companies. Although the regulatory } \\
\text { restrictions on transactions with insiders apply only to the bank subsidiaries of holding companies, } \\
\text { the FBAs encourage banks to adopt these policies corporate-wide to avoid disadvantageous } \\
\text { transactions with affiliates or insiders. While related party transactions that do not involve a } \\
\text { supervised bank may be legal, the agencies still may consider them "unsafe and unsound." In } \\
\text { addition, as consolidated supervisor, the Federal Reserve and the OTS monitor material intra-group } \\
\text { transactions and exposures. They also ensure that holding companies have adequate risk- } \\
\text { management processes in place for the bank as a whole pertaining to such transactions. } \\
\\
\text { The above mentioned statutes and implementing regulations clearly define the individuals and } \\
\text { entities to which the restrictions apply. The definitions are broad and provide limited discretion to } \\
\text { the supervisor to determine whether a particular individual or entity should be subject to the } \\
\text { restrictions. Pursuant to Sections } 22 \text { (g) and 22(h) of the Federal Reserve Act and its implementing } \\
\text { regulation, "Insiders" include executive officers, directors, principal shareholders of the bank or } \\
\text { any of its affiliates and any related interest of (that is, any company controlled by such an executive } \\
\text { officer, director, or principal shareholder). In many situations, extensions of credit made by a bank }\end{array}$ \\
\hline
\end{tabular}


to the family of an insider will be attributed to the insider. Pursuant to sections $23 \mathrm{~A}$ and 23B, as well as sections 22(g) and 22(h) of the Federal Reserve Act, the term "affiliate" includes any entity that directly or indirectly controls, or is under common control with, the insured depository institution. A transaction between a bank and a third party where the funds are transferred to, or used for the benefit of, an affiliate or insider is considered a transaction with that affiliate or insider.

EC 2: Section 23A requires that all covered transactions between a bank and an affiliate be on terms and conditions that are consistent with safe and sound banking practices. Section 23B requires that financial transactions between a bank and an affiliate be on terms and under circumstances, including credit standards, that are at least as favorable to the bank, as those prevailing at the time for comparable transactions with nonaffiliates. Pursuant to section 22(h), extensions of credit by a insured depository institution to an insider must (1) be made on substantially the same terms (including interest rates and collateral) as, and following credit underwriting procedures that are not less stringent than, those prevailing at the time for comparable transactions by the bank with non-insiders and (2) not involve more than the normal risk of repayment. Violations can give rise to reimbursement or formal enforcement actions. These laws set out basic procedural and recordkeeping requirements to ensure compliance with these provisions. Supervisors determine the adequacy of the bank's procedures used to ensure that loans are not made on conditions indicating preferable treatment and otherwise satisfy the requirements of these statutes and the general obligation for all transactions to be consistent with safe and sound banking practices.

EC 3: Extensions of credits to an insider, not including an affiliate company to the bank, must be reviewed and approved by the board if the aggregate exposure, including the proposed amount would exceed US\$500,000 (a lower threshold applies for smaller banks). The insider must not participate in the preparation, discussion or the vote on the loan. There is no regulation requiring board pre-approval for most transactions with bank affiliates, nor for write-offs of related party transactions.

EC 4: The regulatory provisions mentioned above prevent persons benefiting from the exposure or persons related to such individuals from being part of the process of granting and managing the exposure. Supervisors are expected to identify and criticize any situation in which an interested director involves himself in a matter in which he has an interest. Supervisors review policies and procedures for compliance with the regulations governing affiliate transactions and for extension of credits to insiders.

EC 5: The sets of statutes cited above establish quantitative limits on affiliate and insider transactions and collateral requirements on affiliate transactions. The aggregate limits on exposures to affiliates are generally stricter than those for other counterparties, typically 10 percent to a single affiliate and 20 percent to all affiliates of an institution's capital funds respectively. With respect to insiders, the limit on extensions of credit to an individual insider, when aggregated with the amount of all other extensions of credit to that person's related interests, generally may not exceed 15 percent of an institution's capital funds. When aggregated, all extensions of credit to insiders by an institution may not exceed an institution's capital funds. As with any other extension of credit, the supervisor can address problems identified with such exposures by requiring their deduction from capital when assessing capital adequacy and requiring the posting of additional collateral.

EC 6: Banks must identify, through an annual survey, all insiders of the bank and maintain records of all extensions of credit to insiders. The FBAs expect that a bank's MIS identifies and quantifies credits to related parties and that these transactions are routinely reviewed by loan review and management, if this powers is delegated from the board.

EC 7: All BHCs and foreign banking organizations that own a U.S. subsidiary bank must file the quarterly FR Y-8 report on transactions with affiliates. Similar reporting requirements apply to thrift institutions. In addition, certain information regarding extensions of credit to insiders must be 


\begin{tabular}{|c|c|}
\hline & $\begin{array}{l}\text { included in quarterly reports made by all depository institutions to regulators and which are also } \\
\text { publicly available. }\end{array}$ \\
\hline Assessment & Compliant \\
\hline Comments & 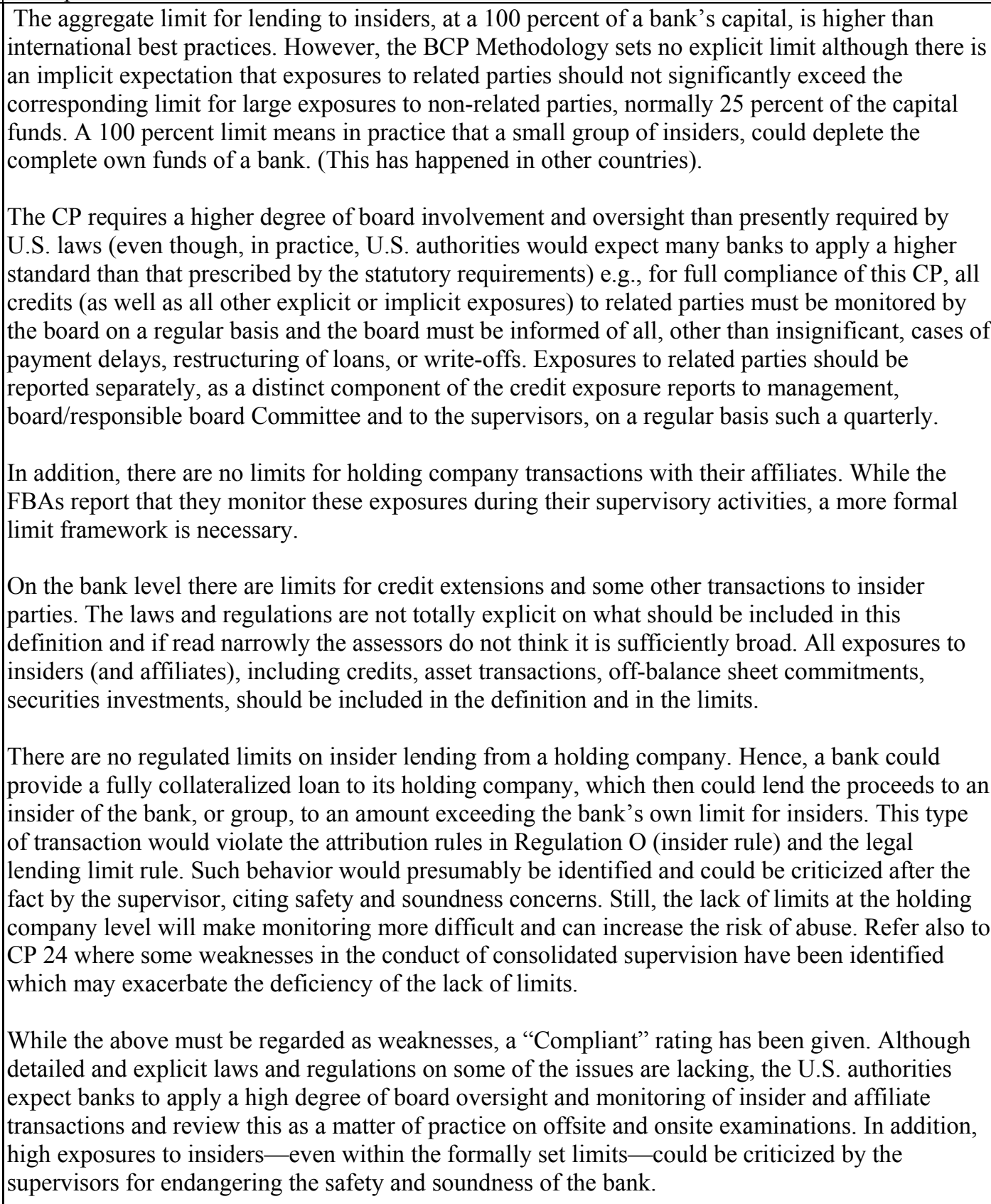 \\
\hline Principle 12. & $\begin{array}{l}\text { Country and transfer risks. Supervisors must be satisfied that banks have adequate policies and } \\
\text { processes for identifying, measuring, monitoring and controlling country risk and transfer risk in } \\
\text { their international lending and investment activities, and for maintaining adequate provisions and } \\
\text { reserves against such risks. }\end{array}$ \\
\hline Description & $\begin{array}{l}\text { EC 1: The system for identification monitoring measuring and control of country and transfer risk } \\
\text { is long established. FBAs are required to evaluate banks' and holding companies' foreign country } \\
\text { exposure and transfer risk for use in examinations and supervision. [See 12 U.S.C. } \$ 3903(a) \text { ]. The } \\
\text { agencies also must ensure that these risks are taken into account in evaluating a bank's or holding } \\
\text { company's capital adequacy. [See id. } \$ 3903(b)] \text {. Banks and holding companies meeting certain } \\
\text { reporting criteria based on cross-border exposure are required to identify and monitor these risks }\end{array}$ \\
\hline
\end{tabular}


and to provide quarterly reports to supervisors on their foreign country exposure.

The quarterly reports detail each bank's or holding company's significant claims on foreign entities, specifying, among other things, the types of claims and country in which the borrowers are located. Necessarily, banks and holding companies must have established policies and procedures for monitoring the countries with which they are doing business and monitoring and evaluating their exposures to those countries.

Representatives of three of the FBAs (the Federal Reserve, OCC, and the FDIC) are part of an "Interagency Country Exposure Review Committee" (ICERC), which meets at least once a year and recently more frequently (the committee reserves the option to meet at any time during the year should circumstances warrant attention) to review conditions in countries that have defaulted by not complying with their external service obligations or are unable to service the existing loan according to its terms, as evidenced by failure to pay principal and interest timely and fully, arrearages, forced restructuring, or rollovers and where U.S. banks and holding companies have large exposures. Based on this review, the ICERC assigns a transfer risk rating to the country and determines whether U.S. banks and holding companies must hold a reserve (an "Allocated Transfer Risk Reserve" or "Allocate Transfer Risk Reserve (ATRR")) against exposures where the country of residence of the ultimate obligor is from the defaulting country. [See 12 CFR 211.43 and Guide to the Interagency Country Exposure Review Committee Process (November 2008)]. Assessors met with the chair and members of ICERC to review the system. ICERC members' expertise is also available as needed to the supervisory process.

However, the statutory provisions do not apply to savings associations and SLHCs supervised by the OTS, which historically have not had large foreign country exposures and transfer risk. For purposes of CP 12, therefore, the word "bank" does not include a savings association. OTS examines large and complex SLHCs for country risk, however, and would require a SLHC to establish an ATRR pursuant to the ICERC's guidelines, if necessary.

During examinations, supervisors assess the bank's or holding company's overall identification and management of country and transfer risk. Banks and holding companies are expected to assess the level of their country-risk exposure and evaluate the effect of prevailing and future economic, political, and social conditions on a country's ability to sustain external debt service, and reflect the impact of these conditions on the credit risk of individual counterparties located in the country. The agencies expect banks and holding companies to have a comprehensive risk-management system to identify their cross-border exposure by borrower and by country, and to quantify exposure, including cross-border guarantees, derivatives, and reference assets, where appropriate. In order effectively to control country risk, supervisors expect that this risk-management system includes oversight by the bank's or holding company's board of directors, well-defined policies and procedures for managing country risk, an accurate country exposure reporting system, an effective country analysis process, a country-risk rating system, established country exposure limits, and adequate internal controls. The guidance and supervisory process is on an end country/end borrower basis and considers all types of direct and indirect country exposures and exposures at various levels in a transaction chain.

EC 2: The FBAs assess a bank's or holding company's information and risk-management systems to evaluate whether a bank or holding company has appropriate risk controls, information systems, and monitoring structure to ensure that cross-border exposures are managed consistently with the bank's or holding company's strategy and risk-management philosophy. Supervisors evaluate whether banks and holding companies have comprehensive reporting systems to accurately capture country risk exposure, ensure adherence to the directives of the board, provide for at least an annual review of portfolio composition by country, and establish a methodology for reporting exceptions. As part of the examination process, supervisors evaluate the frequency and size of exceptions to country limits imposed by banks and holding companies, and, if appropriate, discusses issues with management if weaknesses are noted. Banks and BHCs are required to report their various asset exposures quarterly on the Country Exposure report, FFIEC 009. The agencies 


\begin{tabular}{|c|c|}
\hline & 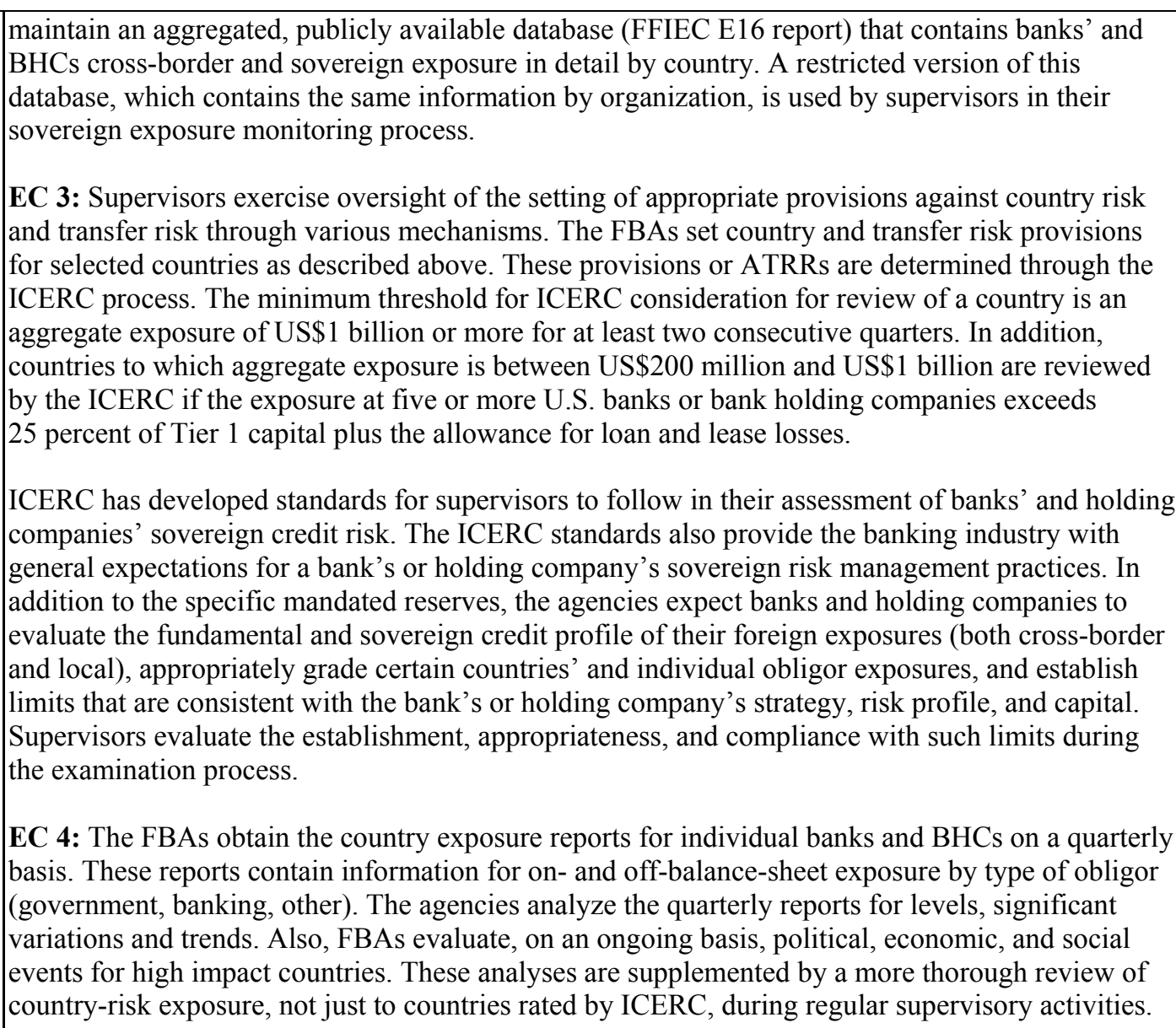 \\
\hline & Compliant \\
\hline Comments & \\
\hline Principle 13. & $\begin{array}{l}\text { Market risk. Supervisors must be satisfied that banks have in place policies and processes that } \\
\text { accurately identify, measure, monitor and control market risks; supervisors should have powers to } \\
\text { impose specific limits and/or a specific capital charge on market risk exposures, if warranted. }\end{array}$ \\
\hline Description & $\begin{array}{l}\text { EC 1: FBAs expect all banks and holding companies, to have in place comprehensive risk } \\
\text { management policies and processes for identifying, evaluating, monitoring, and controlling or } \\
\text { mitigating market risk. Supervisors assess each bank or holding company's exposure to and } \\
\text { management of market risk. For most U.S. banks and holding companies interest rate risk in their } \\
\text { banking books is the predominant market-related risk exposure. Large banks or BHCs also have } \\
\text { much more complex and extensive market risk exposure both in their trading books and available } \\
\text { for sale portfolios. Those with aggregate trading assets and liabilities of US \$1billion or more or } \\
10 \text { percent of total assets are subject to market risk capital rules and related qualitative } \\
\text { requirements that implement the } 1996 \text { Basel I Market Risk Amendment [See } 12 \text { CFR 3, appendix } \\
\text { B]. } \\
\text { Senior management is expected to fully understand the risks involved in the bank's and holding } \\
\text { company's activities, question business line management about those risks, and have prompt and } \\
\text { open discussions about any market-risk control problems or losses. This commitment to market- } \\
\text { risk management is expected to be delineated in practice and codified in written policies and } \\
\text { procedures approved by the board of directors. The agencies' expectations are documented in exam } \\
\text { manuals and published statements regarding the implementation of internal controls including } \\
\text { internal controls for market-risk management. } \\
\text { The supervisory expectations as described in these written documents are implemented via }\end{array}$ \\
\hline
\end{tabular}


monitoring of risk profiles and risk management at supervised banks and holding companies as well as examinations of the banks and holding companies. Continuous monitoring and analysis by on-site teams at larger banks and holding companies entails ongoing analysis of internal reports and discussions with internal management.

Supervisors review these reports to determine if the market risk is appropriately measured, monitored and controlled. A key element of continuous supervision is the review of new product policies and procedures to ensure that the risks of these products are adequately identified so that they may be incorporated into the risk measurement, management, and control processes. Examinations emphasize the need to use multiple measures of market risk and avoid the overreliance on any single measure of risk. These should include a variety of stress tests, value-at-risk measures, position sensitivities, and balance sheet measures which may form a set of limits. FBA teams at major banks have considerable expertise in market risk and are supplemented by risk specialists as needed.

Assessors reviewed off-site monitoring documents as well as examples of continuous monitoring on-site reviews related to market risk. They also discussed the approach to market risk with individual supervisory teams and risk specialist groups. Expertise was evident, though it has been necessary to reallocate some of it to deal with crisis matters and with the conversion of the former investment banks to BHC status. Monitoring material differed between agencies in quality and depth, in part reflecting the differences in market risk exposure between different types of banks.

Currently, certain FBAs are conducting a horizontal review of the banks' implementation of the market risk amendment (MRA), including the quantitative and qualitative market risk management aspects. Detailed reviews of a number of products and models are part of that review. The review was motivated by weaknesses from the recent market turmoil. Prior to this, comprehensive reviews of large financial institutions adherence to the MRA requirements had not been systematically performed. Assessors reviewed the scope and planning documents for this review, which appeared appropriate. Conclusions were not available at this point as the review is ongoing, so it was not possible to judge its effectiveness.

For major firms supervised as banks or holding companies, the predominance of products subject to stress and material losses were held in MTM portfolios. Discussion that the assessors had with FBAs and banks, and recent published reports (e.g., the Senior Supervisors Report) indicate material breakdowns in risk management practices related to MTM portfolios at a number of larger firms. These weaknesses were exacerbated by failures to have an enterprise-wide view of how market, credit and liquidity risks could converge (see CP 7). However, weaknesses in market risk management itself were a material contributing factor. This included weaknesses in understanding the degree of price risks certain firms were assuming, imbalance in authority and influence between risk functions and trading revenue-generating functions at certain major firms, and overreliance on single tools to measure risk such as VaR models, without appreciating their applicability to various products and adequately supplementing them with other risk management processes and appropriate challenge and expert judgments. There were differences in firms' sophistication in the use of VaR models. In some cases interactions between various elements of market risk were missed or mis-estimated (e.g., basis risk). Improvements in these areas are underway. In some cases, especially in areas such as the balance between risk governance and risk taking, it will be necessary for there to be a period of time for supervisors and firms to confirm these are working as expected.

EC 2: Banks and holding companies are expected to establish market-risk limits that are commensurate with their size and complexity and that reflect all material market-risk exposures. Supervisors seek to confirm that banks and holding companies have appropriate limits in place that are developed under the direction of, and approved by, senior management and the board of directors. As part of their examinations, supervisors check the adherence to these limits and discuss with senior management policies and procedures for limit exceptions. These discussions allow supervisors to assess whether senior management is aware of large risk positions and the proper 
approvals for excesses as described in the policies and procedures of the firm have been granted. Limits need not be absolute under the regime of any U.S. supervisor; however, supervisors confirm that appropriate dialogue with non-trading senior management takes place and is documented before limits are exceeded. Supervisors also confirm that policies and procedures address the frequency of review of the limit structure, identify the authority to set and change limits, and ensure that limits are set by personnel independent of the trading activity. Supervisors check approvals for limit excesses to ensure policies are adhered to through transaction testing.

EC 3: Guidance exam manuals and procedures, as well as fundamental U.S. GAAP requirements, address the need for banks to have systems and controls to ensure all positions are captured on a timely basis, and require that MTM positions are revalued frequently using reliable and prudent market data (or in the absence of market prices internal or industry-accepted models).

All public corporations in the U.S. are expected to disclose the value of their positions quarterly on their public financial reports. Trading assets and other assets valued on a MTM basis are reported at fair value in accordance with U.S. GAAP (FAS 157). For banks and holding companies required to file public reports, the Sarbanes-Oxley legislation requires that all critical controls relating to financial reports must be documented and tested, and that weaknesses in these controls must be disclosed in their quarterly public financial reports. Banks and holding companies are subject to these same standards; however, the standards for control and frequency of valuation imposed by financial supervisors are higher for those banks and holding companies with significant trading operations. Prior to the crisis, independent auditors attested to valuation.

Implicitly through requirements for daily VaR modeling, bank and holding company rules effectively require that trading positions be revalued daily and verified by a unit independent of the business unit on a frequent basis in order to meet the standards for risk-management control or regulatory capital. For banks and bank holding companies, the agencies' market-risk capital rules require that its VaR model is used to measure its daily VaR. The FBAs confirm that FAS 157 is appropriately applied for instruments that fall under this statement, and that the bank's or holding company's process is documented and approved by its external auditor.

Recent supervisory reports indicate that many banks and holding companies found that their valuation procedures were not robust to a change in market liquidity. Their valuation procedures had established a single method to value a particular asset that may have relied on suitable prices being observed in a liquid market. When the market for these assets became illiquid, banks and holding companies found that they could not apply a method that relied on observed prices. These banks and holding companies had to develop complex pricing models that met high control standards in an expedited timeframe. This experience indicated the need to develop a "waterfall" of valuation procedures that provided the banks and holding companies with the ability to value positions under a variety of market conditions. The crisis also revealed material weaknesses in some firms' ability to aggregate MTM position across books or geographies and ensure appropriate robust disciplined pricing and valuation (linked to $P \& L$ valuation), with appropriate challenge of business units' own estimates of value of hard-to-measure holdings on a consistent basis. While these shortcomings were exacerbated by several market realities, such as a significant decline in liquidity and uncertainty on the valuation of underlying assets such as sub-prime, basic valuation processes and the IT infrastructure to support them were also weaker at some firms, in some cases because of weak integration of data resulting from multiple mergers.

Discussions with firms, FBAs, and recent published reports indicate firms have made progress in remedying these deficiencies, and the situation differs among major firms, but this will take time, particularly where IT and risk infrastructure improvements are necessary.

Assessors' discussions with banks and audit firms confirmed the considerable difficulties in valuation of complex instruments, the progress that has been made and the considerable ways to go. 


\begin{tabular}{|c|c|}
\hline & 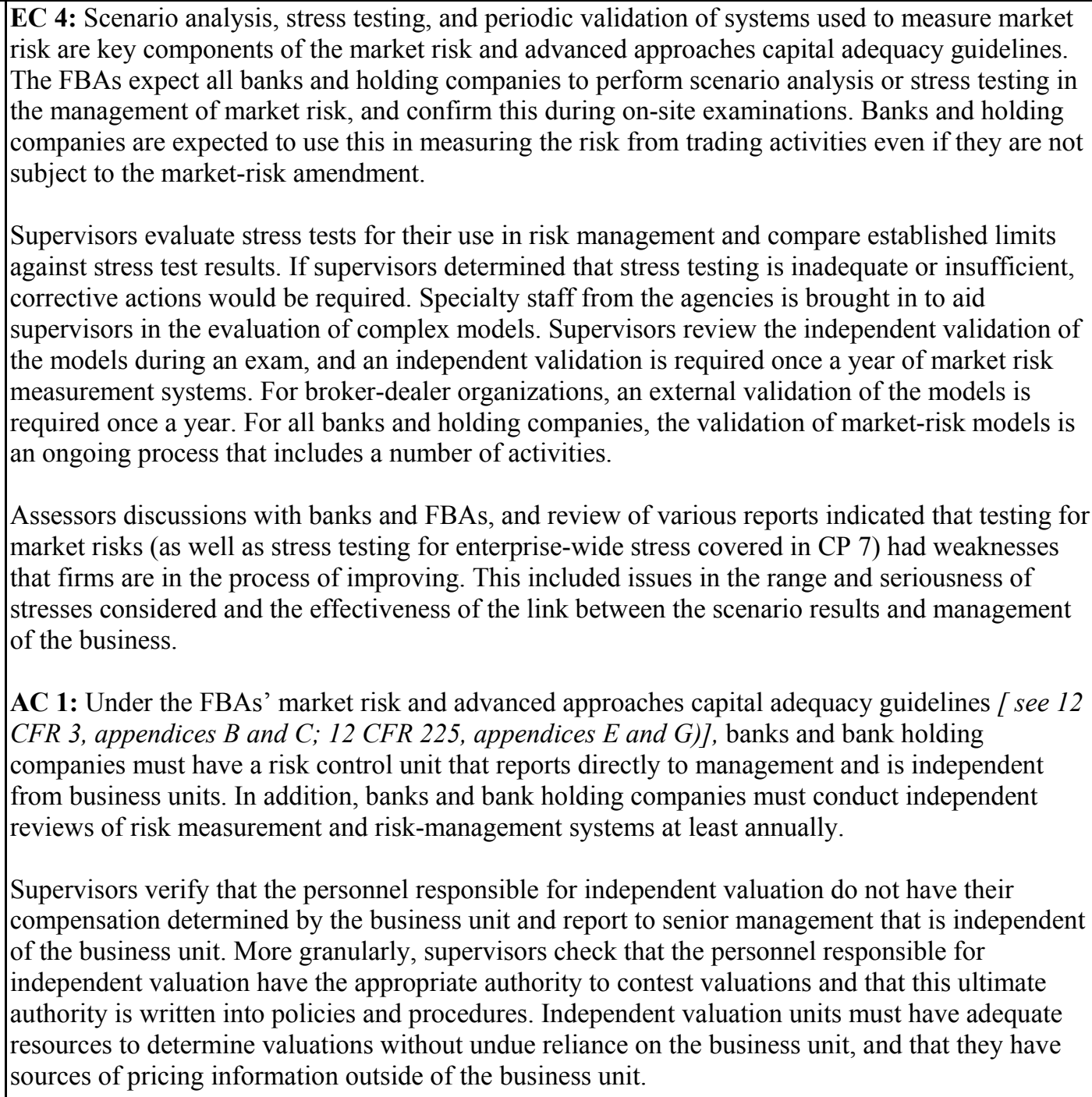 \\
\hline Assessment & Largely Compliant \\
\hline Comments & $\begin{array}{l}\text { As indicated above, material weaknesses have been revealed in market risk monitoring and } \\
\text { management. The major ones are in the areas of suitability of market risk measurement and } \\
\text { monitoring processes and models at certain major firms, lack of reliable valuation of MTM } \\
\text { positions and completeness and use of market stress testing. These are key issues addressed by this } \\
\text { CP. Despite the existence of rules that are compliant with this CP, implementation has not been as } \\
\text { effective as necessary. } \\
\text { The weaknesses arise in essential market risk management practices, not only in weaknesses } \\
\text { related to interaction among market credit and liquidity risk covered in CP } 7 \text {. } \\
\text { Substantive improvements are required and improvements are in progress. But in some cases these } \\
\text { will take considerable time (including supervisory time to verify robustness) particularly where } \\
\text { material improvements in IT or risk architecture or risk culture are involved. It will be important } \\
\text { for banks and supervisors to confirm that the new processes operate effectively as planned, as more } \\
\text { robust market conditions return. This will be particularly important in making sure that the balance } \\
\text { between revenue generating functions and risk oversight functions and risk appetite operates as } \\
\text { expected and that judgment is being mixed with analytics in risk monitoring and risk management. } \\
\text { Better linking compensation to risk, which is only starting to be improved, is relevant to this } \\
\text { balance. }\end{array}$ \\
\hline
\end{tabular}




\begin{tabular}{|c|c|}
\hline & $\begin{array}{l}\text { FBAs have ramped up their resources to deal with additional demands in these areas but need to } \\
\text { recognize that the ongoing resource demands will likely be considerable given the likely need for } \\
\text { more extensive, frequent and in-depth reviews. } \\
\text { FBAs need to complete the current horizontal assessment of the Market Risk Amendment and } \\
\text { determine how much further in-depth horizontal review of market risk and valuation improvements } \\
\text { at major banks is required. There is need for conducting regular, horizontal, in-depth assessments } \\
\text { of major banks' progress, involving both on-site staff and risk specialists. }\end{array}$ \\
\hline Principle 14. & $\begin{array}{l}\text { Liquidity risk. Supervisors must be satisfied that banks have a liquidity management strategy that } \\
\text { takes into account the risk profile of the institution, with prudent policies and processes to identify, } \\
\text { measure, monitor and control liquidity risk, and to manage liquidity on a day-to-day basis. } \\
\text { Supervisors require banks to have contingency plans for handling liquidity problems. }\end{array}$ \\
\hline Description & 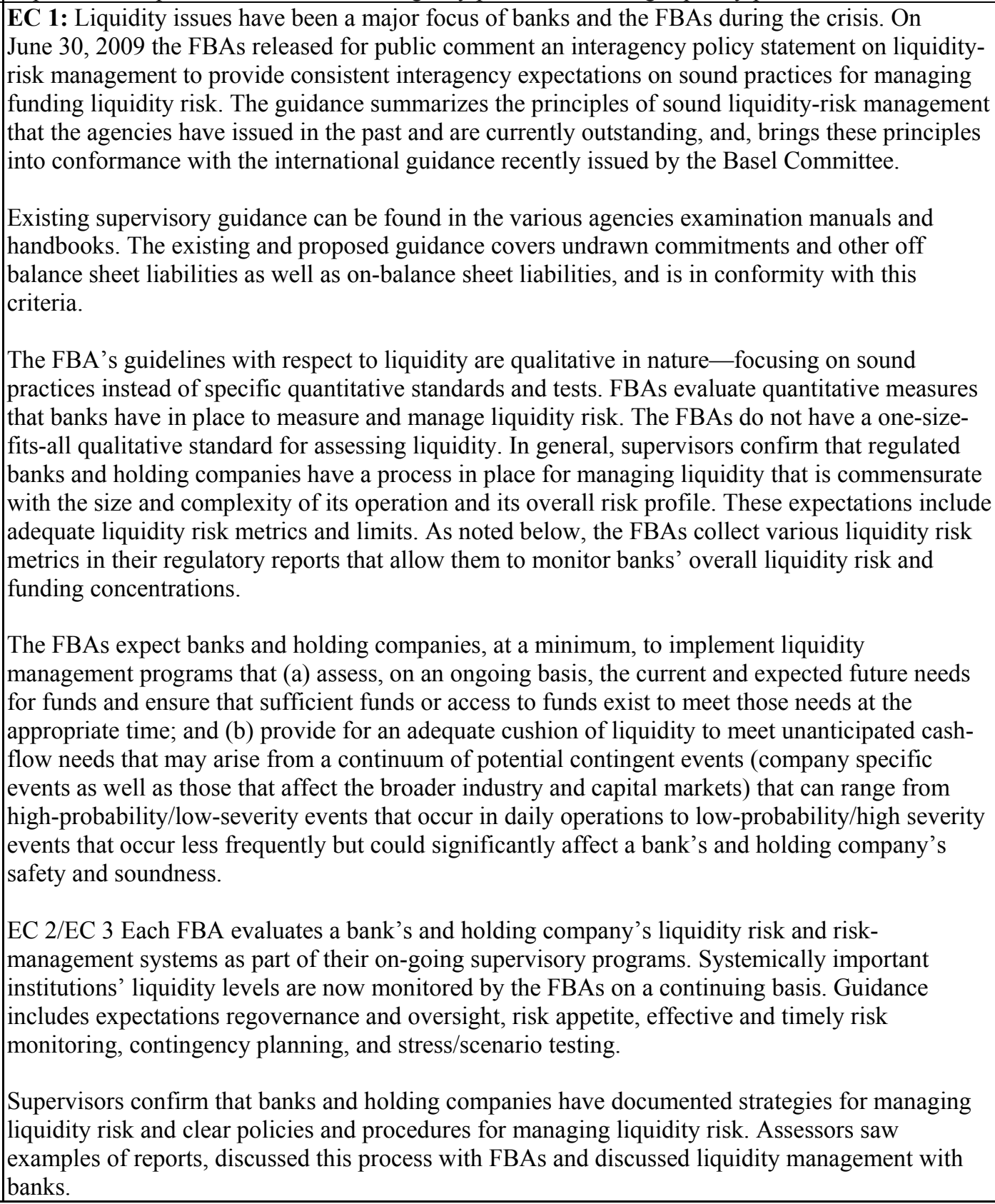 \\
\hline
\end{tabular}


Supervisors also confirm that these policies and procedures are approved by the board of directors of the bank and holding company or an appropriate committee of the board, and reflect the objectives, risk tolerances and goals of the board of directors. These assessments are made by reviewing bank and holding company policies and procedures and management reports, as well as through discussions with the bank's and holding company's management. Supervisors' reviews will also assess whether the board and senior management: have identified lines of authority and responsibility; have articulated the bank's and holding company's general liquidity strategies and its approach to liquidity risk; understand the bank's and holding company's liquidity contingency funding plans; and periodically review the bank's and holding company's liquidity-risk profile.

The UFIRS has a component to rate liquidity (L) in the CAMELS ratings. Liquidity is also evaluated in the 'financial' component of the BHC ratings system and in the "E" component of the SLHC CORE ratings system.

Supervisors determine whether the critical elements of a sound liquidity-risk management process are evident. These include adequate corporate governance, including active involvement by the board of directors and senior management; appropriate strategies, policies, procedures, and limits for controlling liquidity risk; adequate systems and processes for measuring, monitoring, and reporting liquidity risk; comprehensive contingency funding plans for addressing potential adverse liquidity events and meeting emergency cash flow needs; and appropriate internal controls for all aspects of liquidity-risk management. Supervisors evaluate the customization of each of these elements seek to ensure they account for the sophistication, complexity, and business activities of the bank and holding company.

In evaluating the adequacy of a bank's and holding company's liquidity position, supervisors consider the current level and prospective sources of liquidity compared with funding needs, as well as the adequacy of funds-management practices relative to the bank's and holding company's size, complexity, and risk profile.

The agencies' regulatory Call Reports and Thrift Financial Reports collect information on each bank's and holding company's liability and deposit mix, including information on deposit maturities and repricing characteristics. These reports also capture the level of large deposits that may not be covered by FDIC deposit insurance, non-maturity deposits, non-deposit borrowings that may be credit sensitive, and off-balance-sheet commitments. Each agency uses, other monitoring reports and other market related data in various off-site surveillance and monitoring tools to identify banks and holding companies that may have high potential liquidity-risk exposures. The market turmoil led to considerable upgrading in the scope and frequency of liquidity reporting and monitoring, at least part of which the FBAs plan to make a permanent part of their supervisory process.

The assessors discussed with the FBAs and with the banks their extraordinary efforts at monitoring and dealing with liquidity issues during the 2007-2009 period. These involved much more frequent (daily/intra-day) monitoring, more detailed and granular assessment of liquidity positions possible stresses and contingency plans, and dealing with material liquidity issues at banks and holding companies.

The assessors also discussed lessons learned by banks and the FBAs and alterations in approach to liquidity risk measurement and management, and to supervision, that have been put in place as a result. Weaknesses in liquidity management were a major factor in the recent crisis. As a result of extensive hands-on work between supervisors and banks, and international discussion, the attention to liquidity risk management by banks and supervisors has heightened considerably. The FBAs indicate that they intend this will continue. Interagency efforts are underway to craft a liquidity proposal implementing BCBS recommendations.

Market events during the current crisis have moved the agencies to fully assess the overall effectiveness of the implementation of the supervisory processes used in enforcing such guidance. 
Recognizing the need for improvement in implementation of this principle, the agencies have enhanced the supervision of liquidity risk management as follows: 1) issuing consistent supervisory expectations through an interagency statement on sound practices; 2) introducing new Federal Reserve guidance on consolidated supervision that stresses a focus on group-wide as well as legal entity liquidity management; 3 ) introducing new SLHC rating definitions and increased emphasis on enterprise-wide assessment and risk management in the "O" and " $\mathrm{R}$ " components; 4) increasing monitoring of the liquidity risk profiles of banks and holding companies as well as monitoring systemically important institutions liquidity levels on a continuing basis; and 5) improving coordination among the supervisory agencies in assessing quantitative risk profiles as evidenced by the recent Supervisory Capital Assessment Program exercise.

Firms have implemented improvements to deal with identified issues and are generally holding more liquidity. Given the severity and critical importance of liquidity issues to firms ongoing survival, FBAs and banks confirm that, in general, improvements are farthest advanced in this area.

Some of the further progress is dependent on international processes, which the United States is taking an active part in, to further enhance international guidance on liquidity risk management including setting numerical targets.

EC 4: Guidance noted above requires banks to establish policies and processes for liquidity risk management including net funding requirements. These include consideration of how other risks may impact banks' overall liquidity strategy. The interaction of credit, market and liquidity risk is an area that has received material additional attention by banks and supervisors as a result of recent events.

Supervisors review to ensure a bank and holding company conducts stress testing or scenario analysis of its liquidity position. Supervisors evaluate that the stress tests or scenario analyses include an assessment of the potential impact of plausible stress events that are bank and holding company-specific and/or externally-driven events. Also, supervisors determine whether events are stressed under different levels of severity, funding needs are quantified, funding sources are identified, and management processes, reporting and external communication are addressed throughout a stress event. Banks and supervisors the assessors met confirm that liquidity stress and scenario testing has materially improved.

Agencies do not mandate or consider specific implicit or explicit scenarios in their assessment of the liquidity position of a bank and holding company given the diversity of the U.S. banking industry. Rather, the FBAs review the robustness of the scenario analyses and stress tests conducted by banks and holding companies based on the size, complexity, and risk profile. The resiliency of a bank's and holding company's funding liquidity to firm-specific and market-wide stress conditions is also assessed through the supervisory process, which includes off-site monitoring and target examinations. Focus on liquidity stresses by banks and supervisors have understandably increased materially.

EC 5: The FBAs. collects extensive information on foreign currency liquidity issues. The FBAs require banks and holding companies to have a system in place to measure, monitor, and control the liquidity positions for each major currency in which business is conducted. The treatment of foreign currencies in a bank's and holding company's internal liquidity assessment is largely determined by the bank and holding company. Currency mismatches are reviewed during the examination process. Banks and holding companies are expected to be able to manage, monitor, and control their currency exposures. The assumptions regarding currency convertibility are left to each individual bank and holding company to determine. Supervisors review the reasonableness of these assumptions, under both normal and stressed conditions, and supporting documentation. The ICERC process (see CP 12) and the FBAs reviews of cross-border concentrations can assist in this process. 


\begin{tabular}{|c|c|}
\hline & 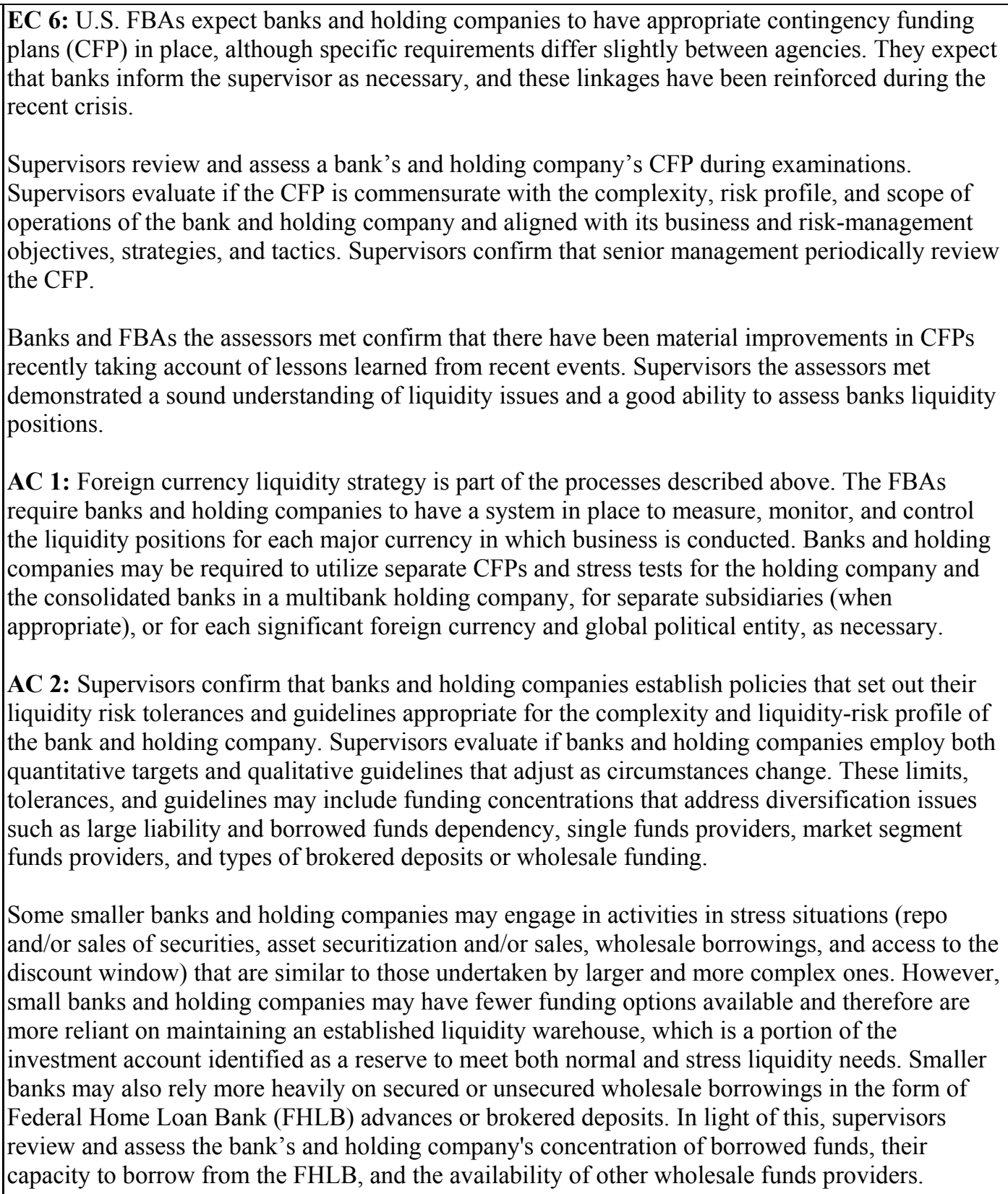 \\
\hline Assessment & Largely Compliant \\
\hline Comments & $\begin{array}{l}\text { FBA guidance is compliant with international standards (though details of those standards are } \\
\text { likely to evolve in the near term). Market events during the crisis moved the FBAs to assess the } \\
\text { overall effectiveness of the implementation of the supervisory processes used in enforcing such } \\
\text { guidance. During the crisis liquidity monitoring was greatly expanded and contingency plans } \\
\text { tested. Improvements are required to make sure these crisis-driven measures in banks and } \\
\text { supervisors are moved into more organized and sustainable improved liquidity risk management by } \\
\text { banks and enhanced regular liquidity risk assessment by supervisors. As a result, formalized } \\
\text { sustainable programs have already been instituted through the joint establishment of the same } \\
\text { liquidity risk data templates used to collect data on institutions at both the OCC and Federal } \\
\text { Reserve. } \\
\text { Further progress to get to the high-quality ongoing liquidity risk management required at major } \\
\text { complex banks including the capability for timely stress testing closely linked to decision is related }\end{array}$ \\
\hline
\end{tabular}




\begin{tabular}{|c|c|}
\hline & $\begin{array}{l}\text { to progress on being better able to aggregate enterprise-wide risk and position information and link } \\
\text { these consistently in a timely manner to P\&L, financial, and balance sheet systems. Because this } \\
\text { requires material IT and risk infrastructure investments, some further time will be necessary. } \\
\text { While much of the enhancements in banks and FBAs to ensure effective implementation and take } \\
\text { account of lessons learned are relatively recent, the heightened focus by supervisors has allowed } \\
\text { them to determine that needed improvements are moving forward. Assessors confirmed in } \\
\text { discussion with the FBAs and banks that progress is well along in banks and in the FBAs. }\end{array}$ \\
\hline Principle 15. & $\begin{array}{l}\text { Operational risk. Supervisors must be satisfied that banks have in place risk management policies } \\
\text { and processes to identify, assess, monitor and control/mitigate operational risk. These policies and } \\
\text { processes should be commensurate with the size and complexity of the bank. }\end{array}$ \\
\hline Description & 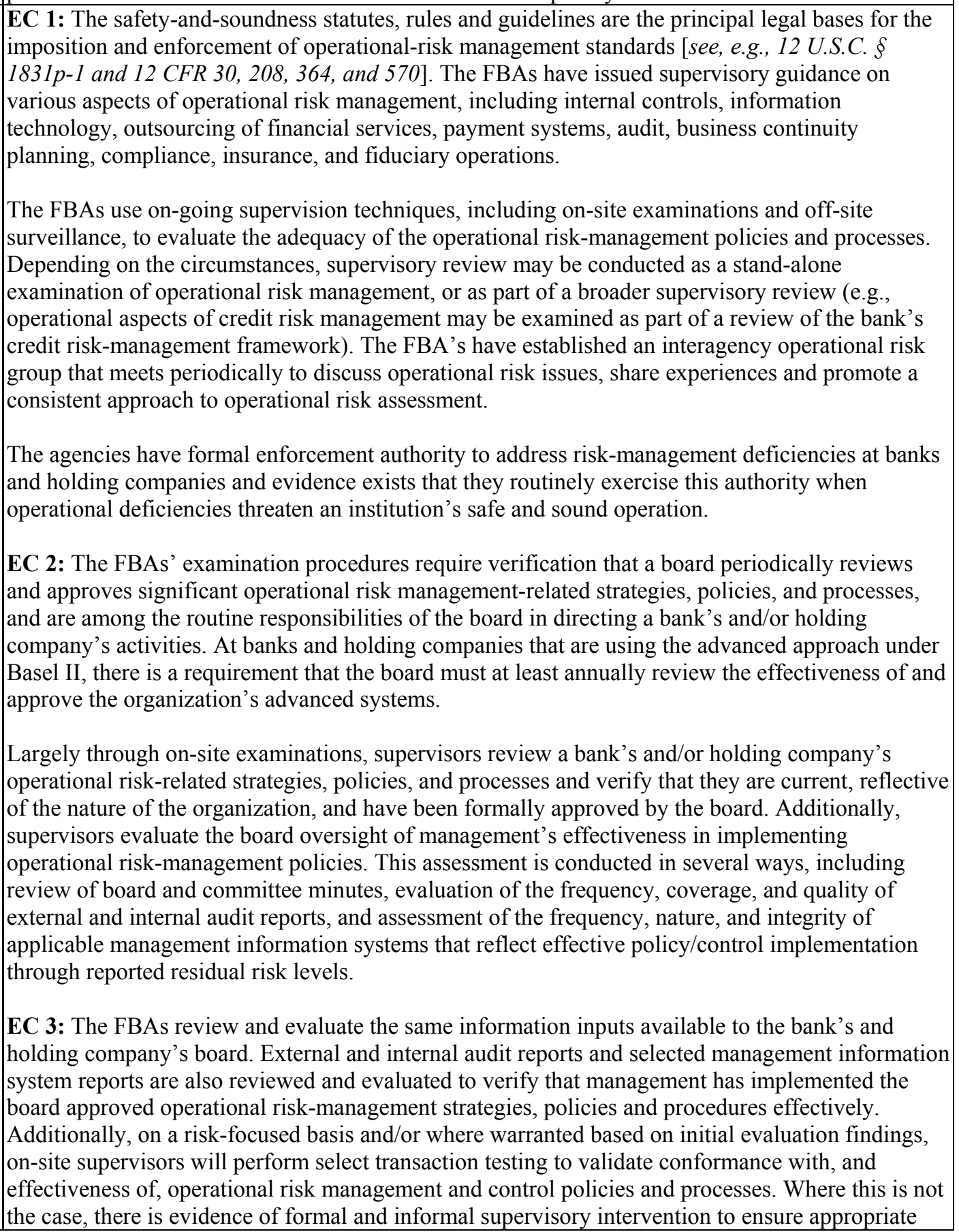 \\
\hline
\end{tabular}


corrective action is undertaken.

EC 4: Various supervisory policies, standards, and/or guidance statements relevant to business resumption and contingency planning have been issued on an interagency basis [see, e.g., March 2008 FFIEC Business Continuity Planning Booklet]. The FBAs have adopted examination procedures and perform risk-focused reviews of banks' and holding companies' business resumption and contingency plans during on-site examinations, with the scope/breadth of review contingent upon the risk profile of the organization. Additionally, under certain circumstances, the business resumption and contingency plans of banks and holding companies, individually by organization and/or horizontally across groups of banks and holding companies, are the subject of both on-site and off-site supervisory activities by the FBAs.

The FBAs have adopted guidelines that are outlined in the Interagency Paper on Sound Practices to Strengthen the Resilience of the U.S. Financial System. These guidelines outline recovery and resumption objectives for clearance and settlement activities that support critical financial markets with the specific goal of limiting systemic/disruption risk to the U.S. financial system. Supervisory programs have integrated these guidelines into their continuous monitoring program and periodic targeted control validation reviews, both of which leverage work already performed by, or conducted in concert with, other banking supervisors and functional regulators. Supervisory oversight of key financial firms - i.e., those that provide core clearing and settlement services that are the backbone of the U.S. financial and international financial systems-have dedicated supervisory teams to assess the adequacy of governance and risk management of critical business/service lines on an ongoing basis.

The FBAs also consider that large holding companies should provide sufficient resiliency measures for the recovery and/or resumption of their most important business processes in the event of a business disruption. The Federal Reserve's supervisory approach focuses on the areas of the greatest systemic risk, i.e., clearing and settlement activities related to critical financial markets. The resulting supervision program establishes a mechanism to conduct ongoing evaluations of the adequacy of risk management over the resiliency and recovery of clearing and settlement activities related to critical financial markets. The supervisory program combines an examination team's continuous monitoring activities, an annual assessment of any material changes in a firm's related activities or characteristics, and periodic targeted control validation reviews.

EC 5: Various supervisory policies, standards, and/or guidance statements relevant to risk management of IT activities have been issued on an interagency basis, many through the FFIEC's ITS, a standing subcommittee of the FFIEC Task Force on Supervision to address security and development. The FFIEC's Information Security booklet provides extensive guidance and examination procedures to evaluate IT security practices. The ITS develops and publishes ITrelated risk-management policies and guidance statements based on industry/market trends or developments in the broader IT environment. This includes the FFIEC's IT Examination Handbook, as well as other more targeted guidance such as Interagency Guidance on Authentication in an Internet Banking Environment (October 2005), Guidance on the Use of Free and Open Source Software (December 2004), Internet "Phishing” Informational Brochure (October 2004), Uniform Rating System for Information Technology (March 1999), and Interagency Supervisory Statement on Risk Management of Client/Server Systems (October 1996). The FBAs also published the Interagency Information Security Standards in May 2001.

The FBAs' supervisory procedures require supervisors to test whether banks and holding companies have appropriate systems in place to address information security and system development. The FBAs each have supervisors with specialized IT skill sets who can lead or assist in examinations of banks and holding companies that have complex IT or operating environments. A special IT rating system has been developed for supervisory assessments (URSIT), as well as a rating system for Technology Service Providers. 


\begin{tabular}{|c|c|}
\hline & 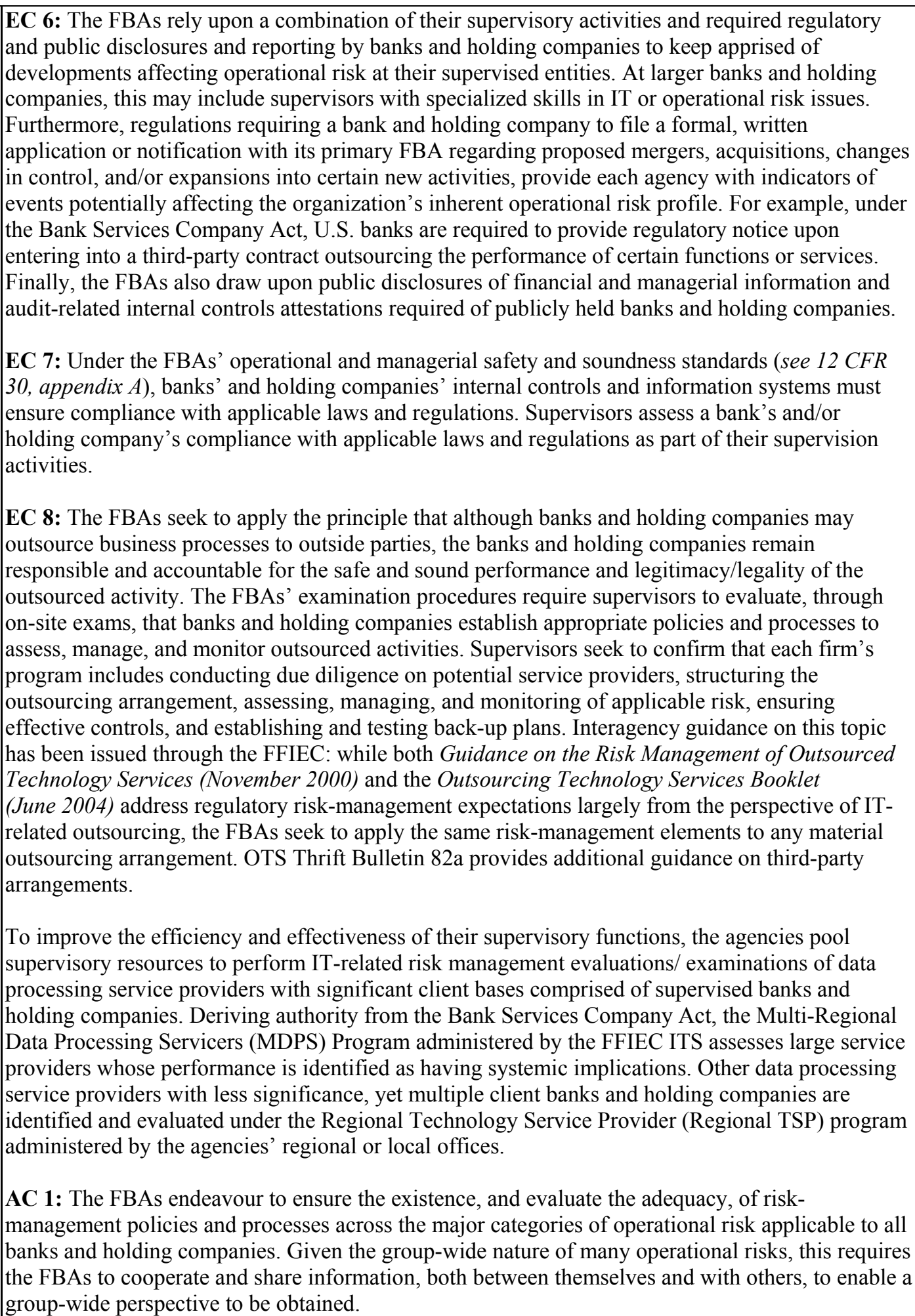 \\
\hline Assessment & Compliant \\
\hline Comments & $\begin{array}{l}\text { Supervision of operational risk appears to be effective overall. Supervisory assessment of a bank's } \\
\text { operational risk management processes and practices are captured in the UFIRS (i.e., CAMELS } \\
\text { rating) although the direct linkage of operational risk to specific component ratings is somewhat } \\
\text { subjective (see CP } 19 \text { for further discussion on this). Ratings systems in other countries (and } \\
\text { indeed, within the individual agencies themselves) typically provide a more defined focus on }\end{array}$ \\
\hline
\end{tabular}




\begin{tabular}{|c|c|}
\hline & $\begin{array}{l}\text { operational risk. The U.S. agencies may wish to reconsider their overall approach to operational } \\
\text { risk, particularly in light of the forthcoming move to Basel II, in which operational risk capital } \\
\text { requirements will need to be assessed against the totality of operational risk being run by a bank. } \\
\text { Furthermore, perhaps more than many other risks, operational risk is typically a group-wide risk } \\
\text { which is not confined to individual legal entities or balance sheets (e.g., IT and accounting systems, } \\
\text { physical security, disaster recovery and business continuity planning). Given the fragmented } \\
\text { supervisory oversight which can sometimes exist of the larger banking groups in the US, there are } \\
\text { limitations on the capacity of individual supervisors to gain a truly group-wide perspective on } \\
\text { operational risk. This requires considerable coordination amongst the agencies to ensure that a } \\
\text { holistic understanding of operational risk of a given banking group is available. The FBAs have } \\
\text { recognised this, and have endeavoured to build the necessary inter-agency coordination } \\
\text { mechanisms (although the extension to non-banking operations is more limited). Examples of good } \\
\text { work that is currently undertaken in this regard are the FFIEC's ITS (which has produced common } \\
\text { examination and guidance material), and the MDPS, Regional TSP and Basel II operational risk } \\
\text { supervisory processes (which involve inter-agency supervision activities). More initiatives of this } \\
\text { type should be encouraged. }\end{array}$ \\
\hline Principle 16. & $\begin{array}{l}\text { Interest rate risk in the banking book. Supervisors must be satisfied that banks have effective } \\
\text { systems in place to identify, measure, monitor and control interest rate risk in the banking book, } \\
\text { including a well defined strategy that has been approved by the board and implemented by senior } \\
\text { management; these should be appropriate to the size and complexity of such risk.. }\end{array}$ \\
\hline Description & 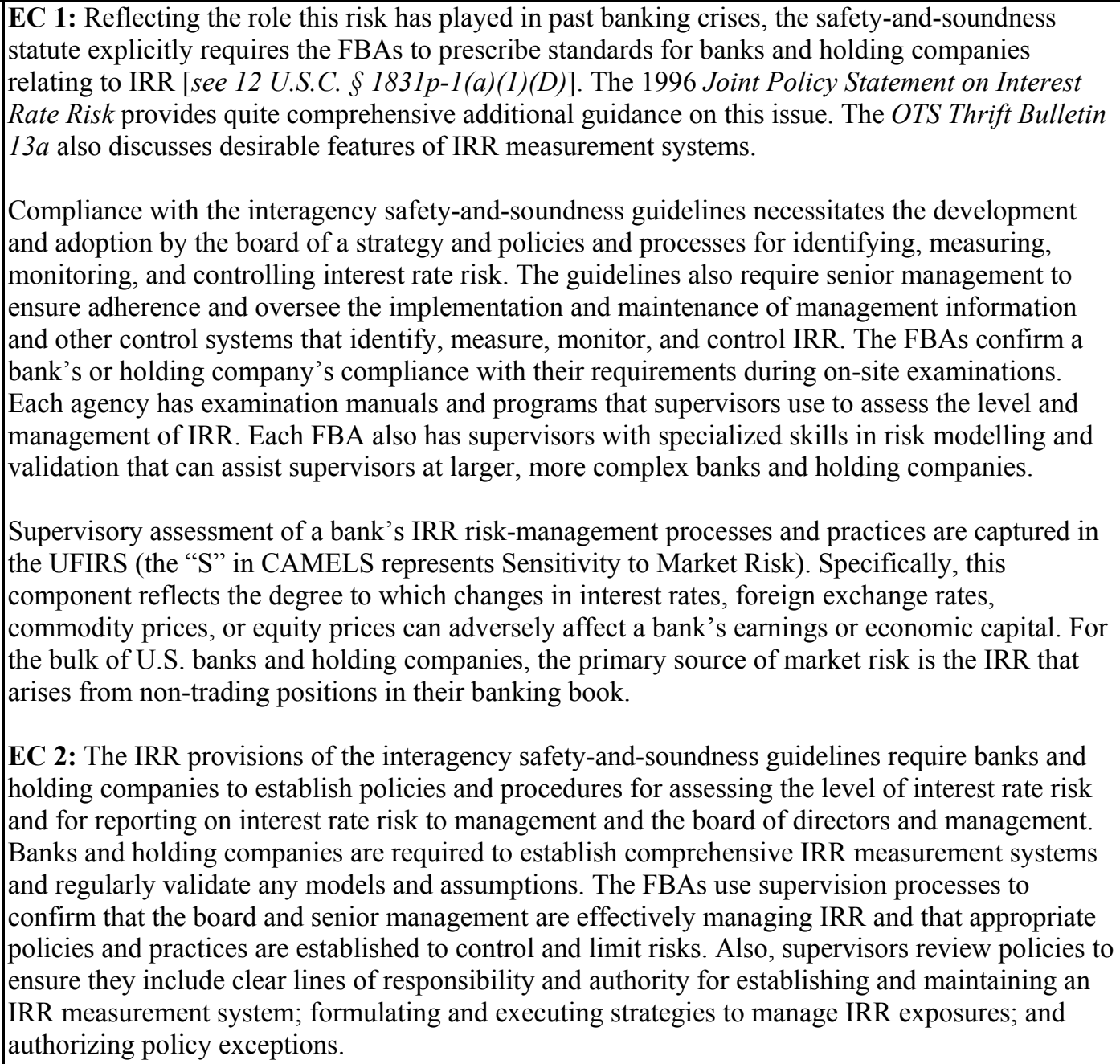 \\
\hline
\end{tabular}


EC 3: The FBAs require that the bank's or holding company's management consider the current level and term structure of rates and possible changes to that environment, given the historical and expected future volatility of market rates. At a minimum, the Joint Policy Statement on Interest Rate Risk suggests that scenarios should include an instantaneous $+/-200$ basis point parallel shift in market rates for a one year time horizon. Beyond that, the agencies have individually issued further supervisory requirements and/or guidance, in varying degrees of detail and prescription, on additional stress testing that they recommend.

AC 1: The supervisory authority to review banks' internal interest rate risk measurement systems is included in section 305 of FDICIA. The FBAs' regulatory Call Reports also include maturity and repricing information on each bank's investment, loan and deposit portfolios. However, with the exception of the OTS, none of the FBAs has a standard measure for interest rate risk.

Due to the high concentrations of mortgage loans and securities that savings associations hold in their portfolios, the OTS's supervisory approach to IRR is somewhat different than that of the other FBAs. The OTS uses its Net Portfolio Value (NPV) Model to monitor the IRR exposures of individual savings associations, as well as the industry as a whole, on a quarterly basis. The NPV Model is described as a non-probabilistic, value-at-risk model, where the value-at-risk is the net economic value of a savings association's portfolio of assets, liabilities, and off-balance sheet (OBS) contracts. In essence, OTS attempts to mark-to-market each savings association's balance sheet under several different interest rate scenarios to determine how the NPV of the savings association changes in response to changes in interest rates. The NPV Model is used to produce Interest Rate Risk Exposure Reports quarterly for a large number of OTS-regulated savings associations. Frequently, these reports are also used as a management tool by small savings associations that do not have their own internal IRR models.

Other agencies utilize the banks' and holding companies' internal measures of risk, and use their own surveillance screens to identify those that appear to be taking excessive risk.

AC 2: The Interagency Policy Statement on Interest Rate Risk states that the adequacy and effectiveness of a bank's or holding company's IRR management process and the level of its interest rate exposure are critical factors the board and senior management need to consider in evaluating that bank's and holding company's capital adequacy.

AC 3: During on-site examinations, the FBAs assess whether stress testing regimes incorporate scenarios large enough to expose all meaningful sources of IRR although, as noted, guidance on the appropriateness of scenarios varies somewhat between agencies. Supervisors also confirm that in developing stress scenarios, banks and holding companies consider a number of factors including the level and shape of the yield curve, sufficiently wide changes in market interest rates and/or yield curve shifts and assumptions about customer behaviour and new business activity that are consistent with each scenario being evaluated. Supervisors test whether senior management and the board periodically review stress test results in order to (i) gain an understanding of the implications of various stress scenarios, (ii) facilitate the review of the entity's risk tolerances and limits, and (iii) provide the basis needed to implement strategies to mitigate the identified risk exposure and realign the risk tolerances.

AC 4: As part of their review processes, the FBAs seek to confirm that banks establish clear lines of authority, responsibilities, and risk limits, and ensure that adequate resources are provided to support the risk monitoring, audit, and control functions. For example, supervisors seek to confirm that the persons or units responsible for risk monitoring and control functions are independent from the persons or units that create the risk exposures. If the risk monitoring and control functions are part of a treasury unit that also has the responsibility and authority to execute investment or hedging strategies to manage the bank's or holding company's risk exposure, supervisors test whether the bank or holding company has a strong internal audit and control function and sufficient safeguards in place. 


\begin{tabular}{|c|c|}
\hline Assessment & Compliant \\
\hline Comments & $\begin{array}{l}\text { From the information made available to the assessors, the FBAs have been effective in the } \\
\text { supervision of interest rate risk-an issue which is of increasing importance in the current } \\
\text { environment. However, while broadly consistent across the FBAs in most material respects, } \\
\text { additional benefits could be obtained from improved consistency in examination approaches and in } \\
\text { measurement techniques. Ideally, there would be a common framework for IRR measurement } \\
\text { across all FBAs, albeit that this common framework could still have variations to take account of } \\
\text { the differences and complexities in measuring IRR in a large internationally-active bank versus a } \\
\text { small community bank with a simple balance sheet. Such a framework could be used as a basis for } \\
\text { better assessing and comparing individual banks and identifying outliers, and to improve the } \\
\text { consistency of assessment and CAMELS rating. }\end{array}$ \\
\hline Principle 17. & $\begin{array}{l}\text { Internal control and audit. Supervisors must be satisfied that banks have in place internal } \\
\text { controls that are adequate for the size and complexity of their business. These should include clear } \\
\text { arrangements for delegating authority and responsibility; separation of the functions that involve } \\
\text { committing the bank, paying away its funds, and accounting for its assets and liabilities; } \\
\text { reconciliation of these processes; safeguarding the bank's assets; and appropriate independent } \\
\text { internal audit and compliance functions to test adherence to these controls as well as applicable } \\
\text { laws and regulations. }\end{array}$ \\
\hline Description & 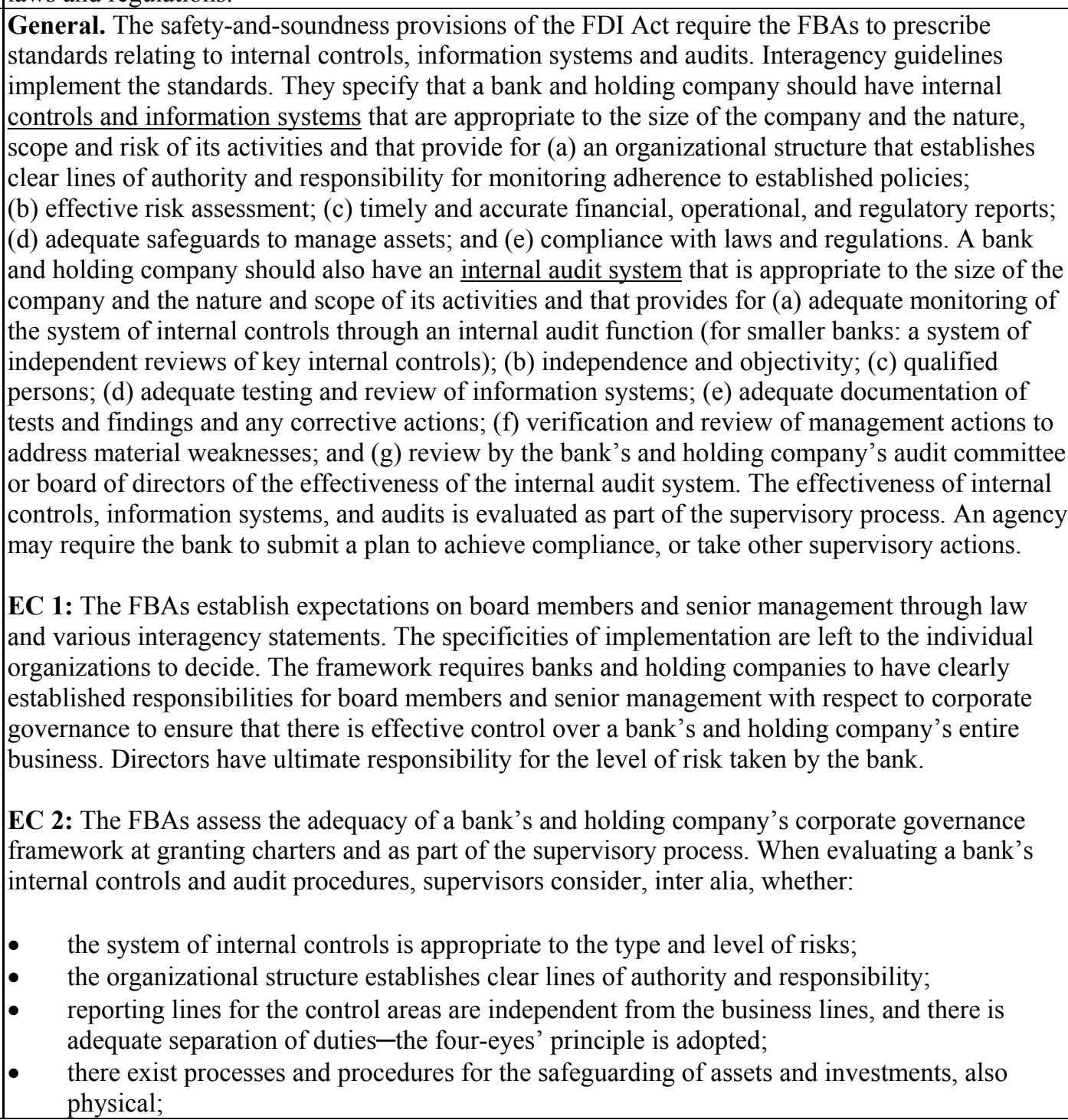 \\
\hline
\end{tabular}




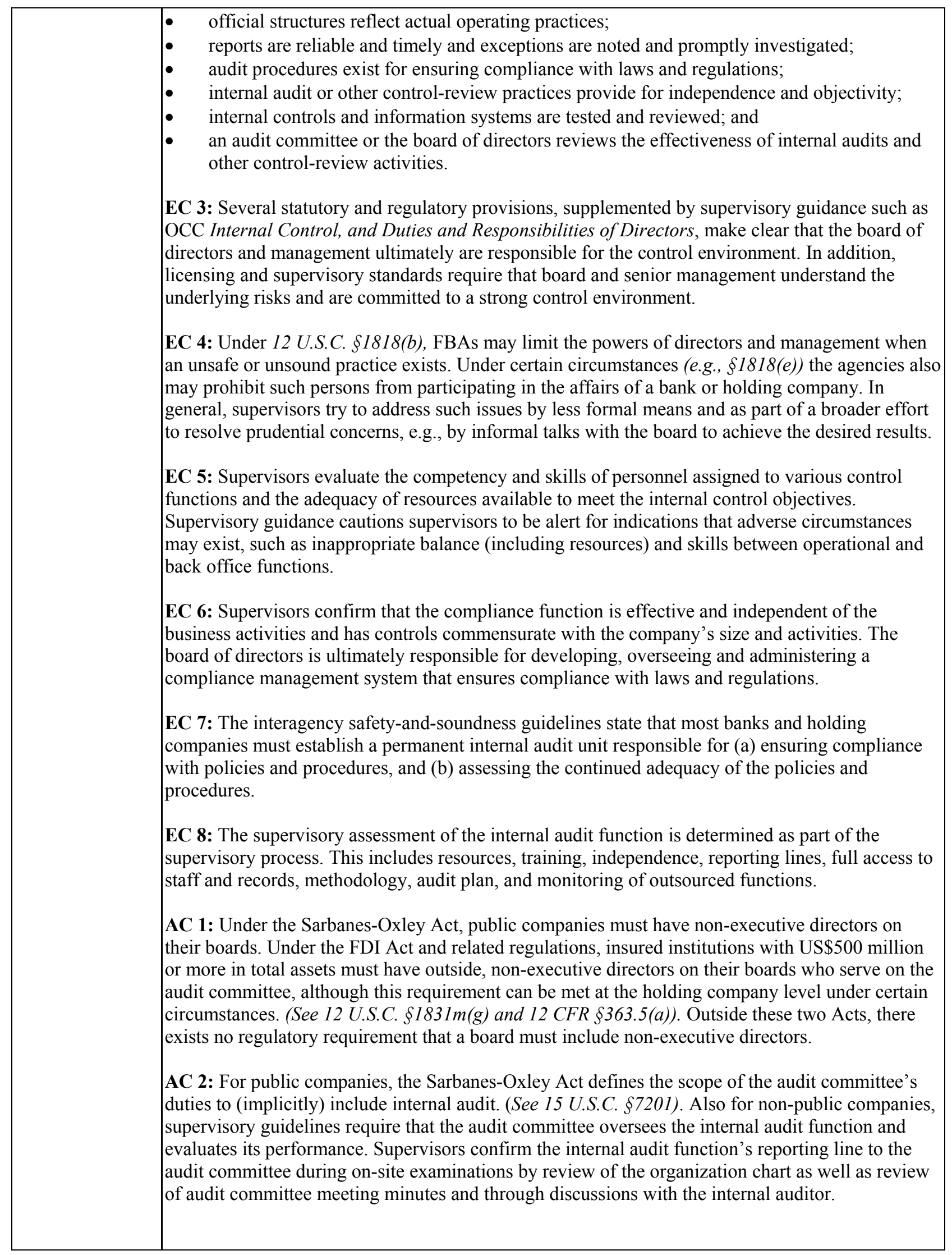




\begin{tabular}{|c|c|}
\hline & $\begin{array}{l}\text { AC 3: For banks and holding companies with total assets of US } \$ 1 \text { billion or more, the audit } \\
\text { committee must be comprised entirely of outside, non-executive directors. For companies with } \\
\text { assets of US } \$ 500 \text { million but less than } 1 \text { billion, the majority of the audit committee must be } \\
\text { outside, non-executive directors (unless an exception is granted by the supervisors). If total assets } \\
\text { exceed US } \$ 3 \text { billion, audit committee members must have financial management expertise, access } \\
\text { to the committee's own outside counsel and not be a large customer of the bank or holding } \\
\text { company. } \\
\text { AC 4: Certain laws or regulations require the bank to notify the supervisor of suspected illegal or } \\
\text { suspicious activity. In addition, although there is no statutory requirement for it, FBAs expect that } \\
\text { notification would be given of any circumstance involving a board or management member that } \\
\text { has the potential to impact the safety and soundness of the bank or holding company. }\end{array}$ \\
\hline Assessment & Compliant \\
\hline Comments & \\
\hline Principle 18. & $\begin{array}{l}\text { Abuse of financial services. Supervisors must be satisfied that banks have adequate policies and } \\
\text { processes in place, including strict "know-your-customer" rules, that promote high ethical and } \\
\text { professional standards in the financial sector and prevent the bank from being used, intentionally or } \\
\text { unintentionally, for criminal activities. }\end{array}$ \\
\hline Description & 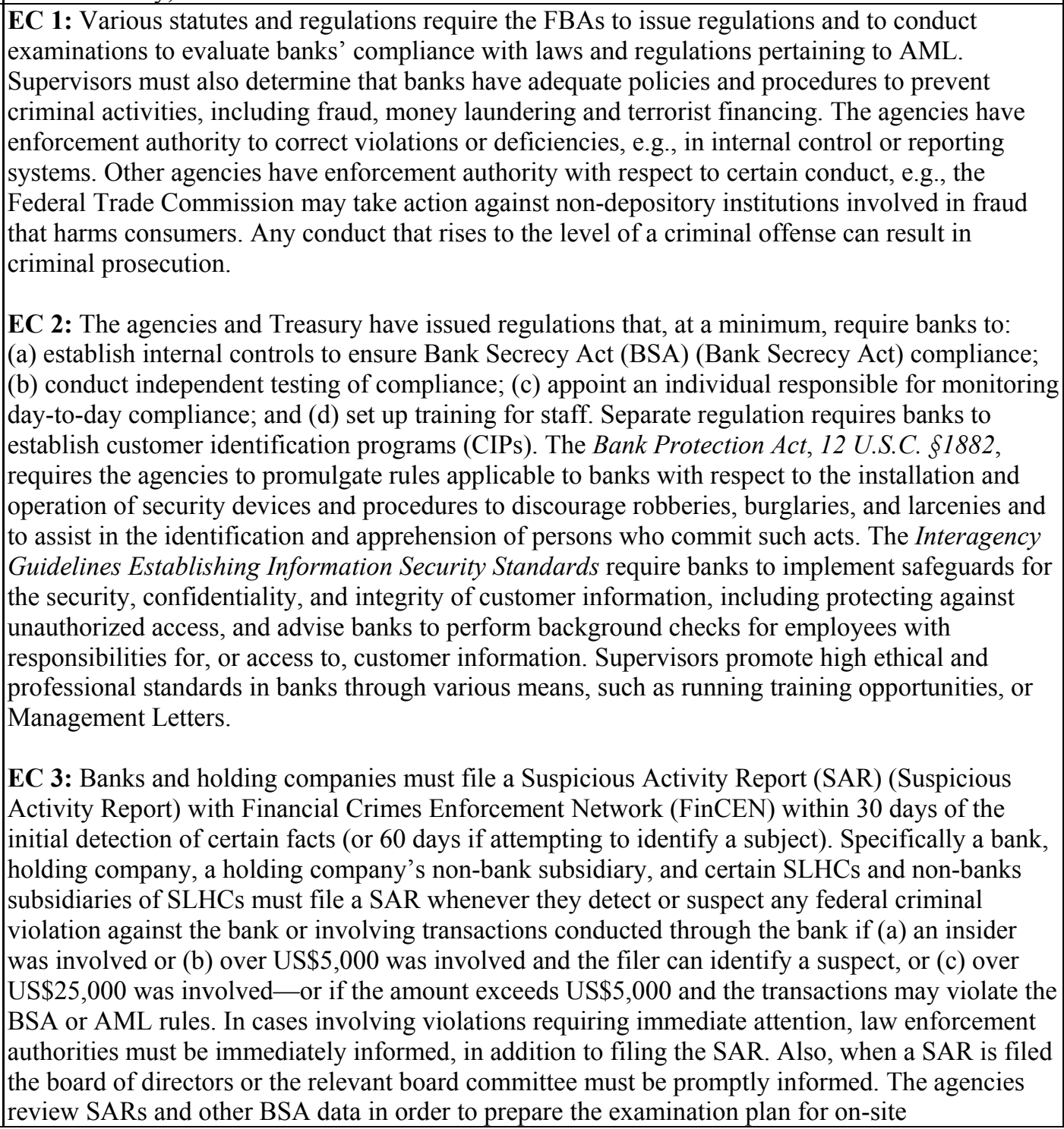 \\
\hline
\end{tabular}


examinations. SARs are also reviewed to ensure that, when needed, enforcement actions are brought against institution affiliated parties, e.g., prohibiting them from further work in the banking industry.

EC 4: Pursuant to 31 U.S.C. $5318(l)$, regulations have been issued requiring customer identification programs, including verifying the identity of any persons seeking to open an account and maintaining records of such information. Banks must establish a CIP for this purpose. The CIP will include the bank's policy and procedures for responding to circumstances in which the bank cannot form a reasonable belief that it knows the true identity of a customer. For certain, notably in private banking, non-U.S. accounts and transactions, banks must identify beneficial owners.

However, in practice, banks are expected, and do, apply the standards also for other accounts and transactions. Regulations generally require that copies of records and reports are kept current and maintained for a period of five years following the completion of the transaction. Supervisors determine whether the internal controls include prudent opening procedures and ongoing monitoring systems. Supervisors also review whether banks identify politically exposed persons (PEPs) and monitor their accounts on an ongoing basis at a high managerial level. All banks must establish a BSA/AML Compliance Program, which includes CIP and customer due diligence (CDD) policies, procedures and processes for all customers, more detailed procedures are required for those that present a high risk for money laundering and terrorist financing.

EC 5: 31 U.S.C. $5318(i)$ and its implementing regulation require banks to establish due diligence policies and procedures reasonably designed to detect and report money laundering through correspondent accounts established, maintained, administered, or managed in the United .States. for a foreign financial institution. In addition, banks must perform enhanced due diligence for foreign correspondent banks with certain high-risk banking licenses. This includes obtaining ownership information about certain correspondents, conducting additional scrutiny of the transactions routed through these accounts, and ascertaining whether the foreign correspondent provides access to other foreign financial institutions. 31 U.S.C. $\$ 5318(j)$ prohibit U.S. banks from providing correspondent accounts to shell banks. The U.S. federal and state agencies also generally evaluate U.S. banks that offer correspondent bank services to domestic respondent banks. The reviews include the policies, procedures and processes to manage the BSA/AML risks involved in these relationships and to detect and report suspicious activities. Supervisors expect, and will verify during onsite examinations, banks to terminate their relationships with foreign correspondents whose policies and procedures and processes on BSA/AML risks are deemed as inadequate.

EC 6: Under 12 U.S.C. $\$ 1818(s)$, each FBA is required to regularly examine the institution's BSA Compliance Program. Prior to the examination, supervisors routinely conduct an off-site review of the FinCEN databases relative to bank SARs and currency transaction reports (CTRs) to determine if the bank has filed such reports and that they appear complete and timely. For complex banking organizations, the agencies maintain resident on-site supervisors who perform continuous monitoring of the control infrastructure and annually assess the organization's condition and risk assessment. The agencies also alert the industry of fraud schemes through bulletins and industry conferences.

EC 7: An agency may take formal or informal enforcement actions to address violations of BSA/AML requirements, Office of Foreign Assets Control (OFAC) deficiencies, and unsafe and unsound practices or breaches of fiduciary duty involving failure to comply with obligations related to criminal activity. When relevant, 12 U.S.C. $\$ 1818(\mathrm{~s})(3)$ requires an agency to issue a cease and desist order to address a violation of the BSA Compliance Program or other actions to be taken to enforce compliance with the Bank Secrecy Act. The FBAs and FinCEN also has the authority to assess penalties for violations of the BSA. The Department of Justice (DOJ) has the authority to bring criminal cases against banks or holding companies for violations against criminal statutes, including parts of the BSA.

EC 8: Banks must have adequate BSA/AML Compliance Programs in place that includes internal controls for the operation and function of the bank's program; independent testing of the bank's 


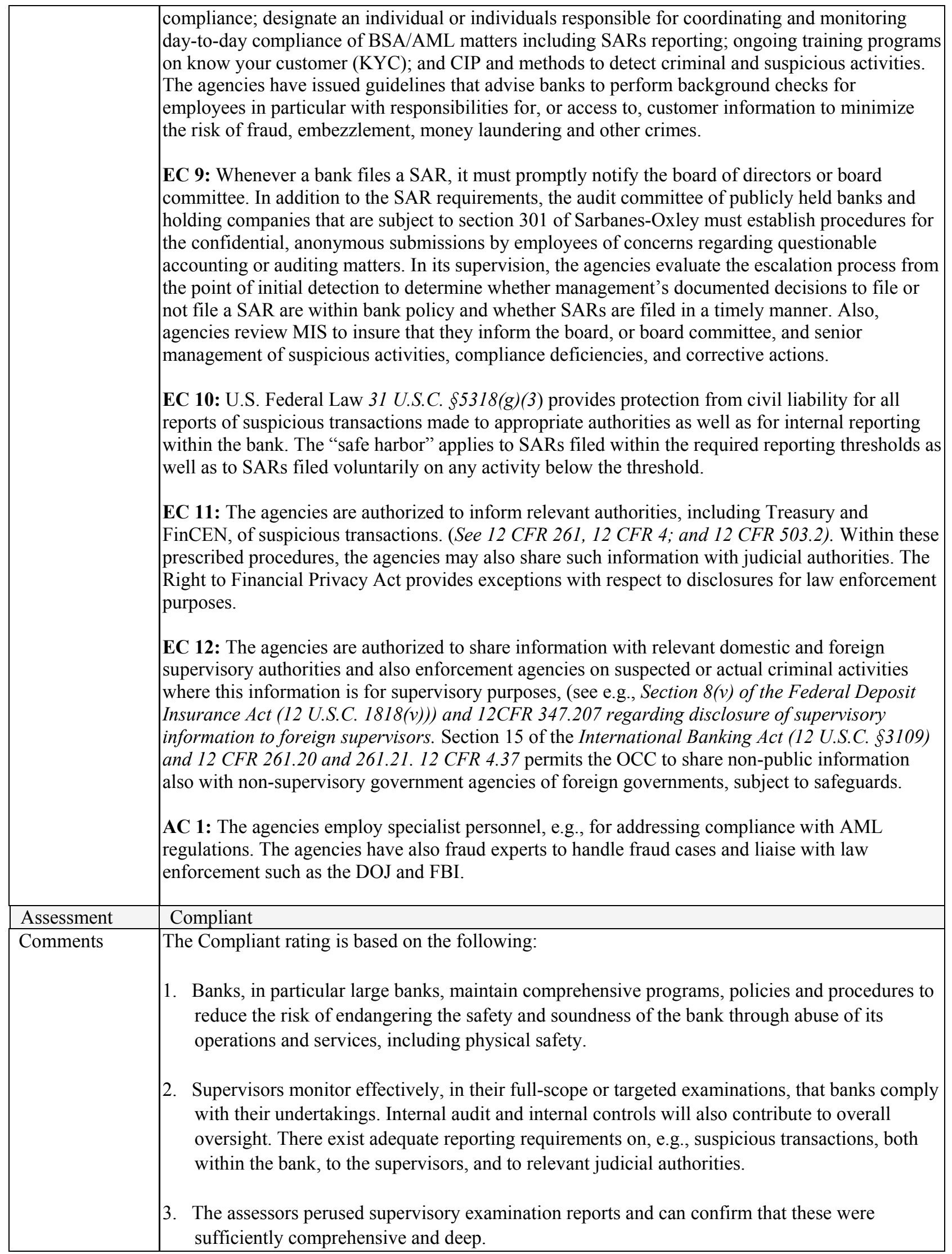




\begin{tabular}{|c|c|}
\hline & $\begin{array}{l}\text { On the relationship between CP } 18 \text { and the FATF assessments: } \\
\text { A. AML/CFT issues constitute only a part of CP } 18 \text {, which encompasses all issues of abuse, } \\
\text { including fraud, embezzlement, robbery, phishing and more. } \\
\text { B. Only those AML/CFT issues which are clearly relevant to the safety and soundness of the bank } \\
\text { are relevant to CP } 18 \text {. } \\
\text { C. A separate FATF assessment was conducted in } 2006 \text { and an IMF update is part of the current } \\
\text { FSAP. The BCP assessors were informed that the authorities have addressed several of the } \\
\text { earlier identified weaknesses. } \\
\text { Below, a number of deficiencies identified in the } 2006 \text { assessment are quoted. These are, indeed, } \\
\text { relevant to banks but the assessors did not deem them to be of sufficient materiality, in the sense of } \\
\text { the BCP/CP } 18 \text { methodology, to warrant a downgrade. That said, the assessors support FATF's } \\
\text { recommendation that these deficiencies be remedied. } \\
\text { - Obligations to identify beneficial owners are limited to specific circumstances, such as } \\
\text { correspondent banking and private banking for non-U.S. clients. } \\
\text { - No measures in place to ensure that there is adequate, timely and accurate information on the } \\
\text { beneficial ownership and control of legal persons that can be obtained or accessed in a timely } \\
\text { fashion by the competent authorities. } \\
\text { - Minimal information concerning the beneficial owners of trusts that can be obtained or } \\
\text { accessed by the competent authorities in a timely fashion. } \\
\text { - No explicit obligation to conduct ongoing due diligence, except in certain defined } \\
\text { circumstances } \\
\text { - Customer identification for occasional transactions limited to cash deals only. } \\
\text { - Verification of identity until after the establishment of the business relationship is not limited } \\
\text { to circumstance where it is essential not to interrupt the normal course of business. } \\
\text { accounts. }\end{array}$ \\
\hline Principle 19. & $\begin{array}{l}\text { Supervisory approach. An effective banking supervisory system requires that supervisors develop } \\
\text { and maintain a thorough understanding of the operations of individual banks and banking groups, } \\
\text { and also of the banking system as a whole, focusing on safety and soundness, and the stability of } \\
\text { the banking system. }\end{array}$ \\
\hline Description & $\begin{array}{l}\text { EC 1: Banking laws vest the FBAs collectively with broad, but not unlimited, authority to regulate } \\
\text { and supervise banks and holding companies subject to their jurisdiction. The FBAs use their } \\
\text { authority to conduct on-site reviews and off-site analyses to develop a thorough understanding of } \\
\text { the risk profile of banks and holding companies. } \\
\text { The primary tool of supervision is the on-site examination. Under U.S. law, the FBAs conduct full- } \\
\text { scope on-site examinations of banks at least once every year (for banks that have assets of less than } \\
\text { US } \$ 500 \text { million and that are considered well-managed and well-capitalized, this may extend to } \\
18 \text { months). Bank holding company inspection cycles are mandated depending upon size, } \\
\text { complexity, and rating. SLHC examinations are conducted concurrently with the OTS examination } \\
\text { of its subsidiary savings associations. } \\
\text { A full-scope examination addresses all key areas of a bank's operations. For many larger banks and }\end{array}$ \\
\hline
\end{tabular}


holding companies, one or more of the banking agencies maintains a full-time, on-site examination staff to monitor the activities (for the very largest banks, this could aggregate across the FBAs to as many as 80 people full-time; this is supplemented even further by additional rotating examiners during the course of the examination cycle). In these cases, full scope examinations/inspections consist of a series of targeted reviews during the examination cycle which culminate in a roll-up process where ratings are assigned based upon the results of these targets and the continuous monitoring activities. The requirements and mandates for these on-site activities are contained in the individual agencies' examination manuals and other guidance to examiners.

During the period of time in between full-scope, on-site examinations, the FBAs use off-site surveillance to maintain their understanding of the bank's and holding company's risk profiles. CP 20 provides further detail of the sources of information used for off-site analysis. These sources may be supplemented by discussions with the banking organization's management, meetings with its internal and external auditors, and, where no full-time on-site examination staff is maintained, targeted on-site visits to maintain an up-to-date understanding of the financial condition. In addition, the agencies maintain various systematized analytical tools that can help identify emerging risks or changes in the risk profile that may require specified follow-up steps (Fed SABR; OCC - Canary; FDIC - SCOR; OTS - RMS). These tools are used to alert examination staff to potential risks or issues that need to be reviewed as a matter of priority.

As noted elsewhere, all of these mechanisms are constrained to some extent when the individual agency is not the supervisor of the entire group, or part of the group is subject to the primary oversight of another functional regulator. The GLB Act imposes a responsibility on the FBAs to defer to another functional regulator where the latter exists, except in exceptional circumstances. Ad-hoc information sharing mechanisms have been established between agencies to try to ensure a broader, group-wide perspective of a bank's or holding company's risk profile can be developed.

EC 2: Using aggregations of quarterly data collections, each agency completes analyses addressing overall conditions within their regulated portfolio. Within the capacity of the data collected, these analyses highlight issues such as earnings performance, capitalization levels, and lending concentrations, and are used to assess trends, developments, and risks for the system as a whole. Each agency also employs a variety of higher level committees and coordination mechanisms to evaluate and assess the risks facing the system and provide feedback to supervisory staff.

The FBAs also seek to maintain contacts with a variety of market and industry analysts to obtain insights on emerging risks that may affect the banking system and financial markets as a whole. The FBAs consult with the supervisors of major non-bank organizations in the United States, including the SEC in the case of broker-dealers and the state insurance authorities in the case of insurance companies, to help to evaluate the impact of these institutions' activities on the condition of holding companies. At this stage, however, the agencies have not chosen to employ the 'supervisory college' concept domestically (involving relevant banking and non-banking regulators) for the largest, most diverse and most complex banking groups.

All agencies noted the challenge they faced in developing a good overall assessment of the state and direction of the banking industry, given (i) the limits of their own individual mandates, (ii) the unknown risks and activities associated with non-bank activities within the group or holding company, (iii) the banking industry's size and complexity, and (iv) the sophistication and interconnectivity of the broader U.S. financial system.

EC 3: During each supervisory cycle, the FBAs formally assess the risk profile of each bank and holding company in order to determine the supervisory strategy to be followed by examination staff and prioritization of agency resources. Risk assessments are updated on a regular basis through off-site monitoring programs and on-site examinations, although typically the formal reassessment (e.g., of the composite CAMELS ratings) occurs on an annual cycle. Banks and holding companies showing signs of significant deterioration or making significant changes in their business focus may be subject to immediate on-site or targeted examination, or the supervisory 
plan for the period ahead intensified, depending on the circumstances.

The agencies' Uniform Bank Performance Report or Uniform Thrift Performance Report allows supervisors and supervisory staff to compare financial trends across groups of peer banks to identify outlier or high risk banks. The FBAs also use the UFIRS (i.e., CAMELS rating system) to provide a methodology and terminology for assessing and assigning risk ratings across banks. Additional uniform rating systems are used to assess information technology (URSIT ratings), trust (MOECA), and consumer compliance systems. Bank holding companies receive RFI ratings, SLHCs receive CORE ratings and the Risk Management; Operational Controls; Compliance; and Asset Quality (ROCA) rating system is used for foreign banking organizations.

Many of these ratings, however, do not appear to be sufficiently responsive to changing risk profiles, or to adequately distinguish between banks of varying risk profiles. For example, based on the statistics presented to the assessors, more than half of all banks in the United .States. are rated within a single CAMELS grading category (and more than three-quarters sit within two rating grades). This limits the usefulness of the key rating tool as means of distinguishing between banks, and developing risk-based resource allocation. The assessors noted that each agency has developed its own internal tools to better assess evaluate the risk profiles of individual banks; at least in some cases, these internal ratings tended to be more influential on oversight and resource allocation than the UFIRS.

EC 4: During regular on-site examinations, the FBAs complete a series of testing procedures, contained in each agency's examination manuals, to confirm banks' and holding companies' compliance with prudential regulations and other legal requirements. In addition, compliance with some rules is monitored on an ongoing basis through the collection and analysis of financial and structure reports that must be filed. The FBAs also seek to confirm that banks and holding companies maintain policies and procedures designed to ensure their compliance with applicable laws and regulations. The FBAs have developed and maintain extensive supervisory guidance to evaluate compliance programs and specific areas including internal controls, audit, consumer protection, fair credit reporting, home mortgage disclosure, real estate settlement procedures, and anti-money-laundering, among others.

EC 5: The FBAs generally expect banks and holding companies to notify them of any substantive changes in their activities, structure and overall condition, or as soon as they become aware of any material adverse developments, including breach of legal or prudential requirements. Further, statute or the FBAs may impose specific notification requirements on banks. Examples (which may not be common to all FBAs) include requirements to establish or relocate a branch, for corporate reorganizations, or to establish or acquire a subsidiary. In the case of new banks and holding companies, the FBAs routinely include a condition in their approval orders that requires prior notice of any change to the new organization's business plan during the first three years of operation. After this period, changes in the activities, if permissible under state and federal law, would generally be subject to review during periodic safety-and-soundness examinations, although some new activities would continue to require a notice or application. CP 4 and CP 5 provide further detail regarding transfer of significant ownership and for major acquisitions.

EC 6: Each FBA maintains a set of databases containing examination, financial, and structure data to facilitate the processing, monitoring, and analysis of prudential information. These data sources are used through a number of agency-specific surveillance tools to support ongoing off-site analysis of, and follow-up action on, banking conditions both at banks and holding companies and within the industry as a whole. For example, agency exam databases can identify for banks and holding companies matters requiring the bank's, holding company's or their respective board's attention for agency follow-up. A reasonable amount of this information is shared between the agencies, although full access to each other's information is usually seen as unnecessary.

Specific to financial data, each bank is required to file complete financial data to the Central Data Repository (CDR) on a quarterly basis. The format utilized for this process is known as the Call 


\begin{tabular}{|c|c|}
\hline & $\begin{array}{l}\text { Report. The data contained within the report is processed within the CDR by the FFIEC and is then } \\
\text { utilized in a multitude of distinctive formats across each of the regulatory agencies, and even by the } \\
\text { general public. The resulting data provide the agencies the ability to produce high level reports of } \\
\text { the condition of the banking system in various formats. } \\
\text { AC 1: Through their ongoing risk assessment processes, the agencies look for risks that may be } \\
\text { increasing or risk-management systems that may need improvements. Each of the FBAs also } \\
\text { employs well defined off-site surveillance procedures that focus heavily on identifying banks and } \\
\text { holding companies that are exhibiting problems or deteriorating so that examination resources can } \\
\text { be directed to troubled organizations or emerging threats. } \\
\text { The FBAs conduct annually a joint review of the largest, complex credits that are shared by three } \\
\text { or more banks. This annual review provides an opportunity for the agencies to identify trends in } \\
\text { underwriting and credit classification practices, as well as overall commercial credit conditions, } \\
\text { across the banking system (see CP } 9 \text { for details of the scale of this program). }\end{array}$ \\
\hline Assessment & Largely Compliant \\
\hline Comments & 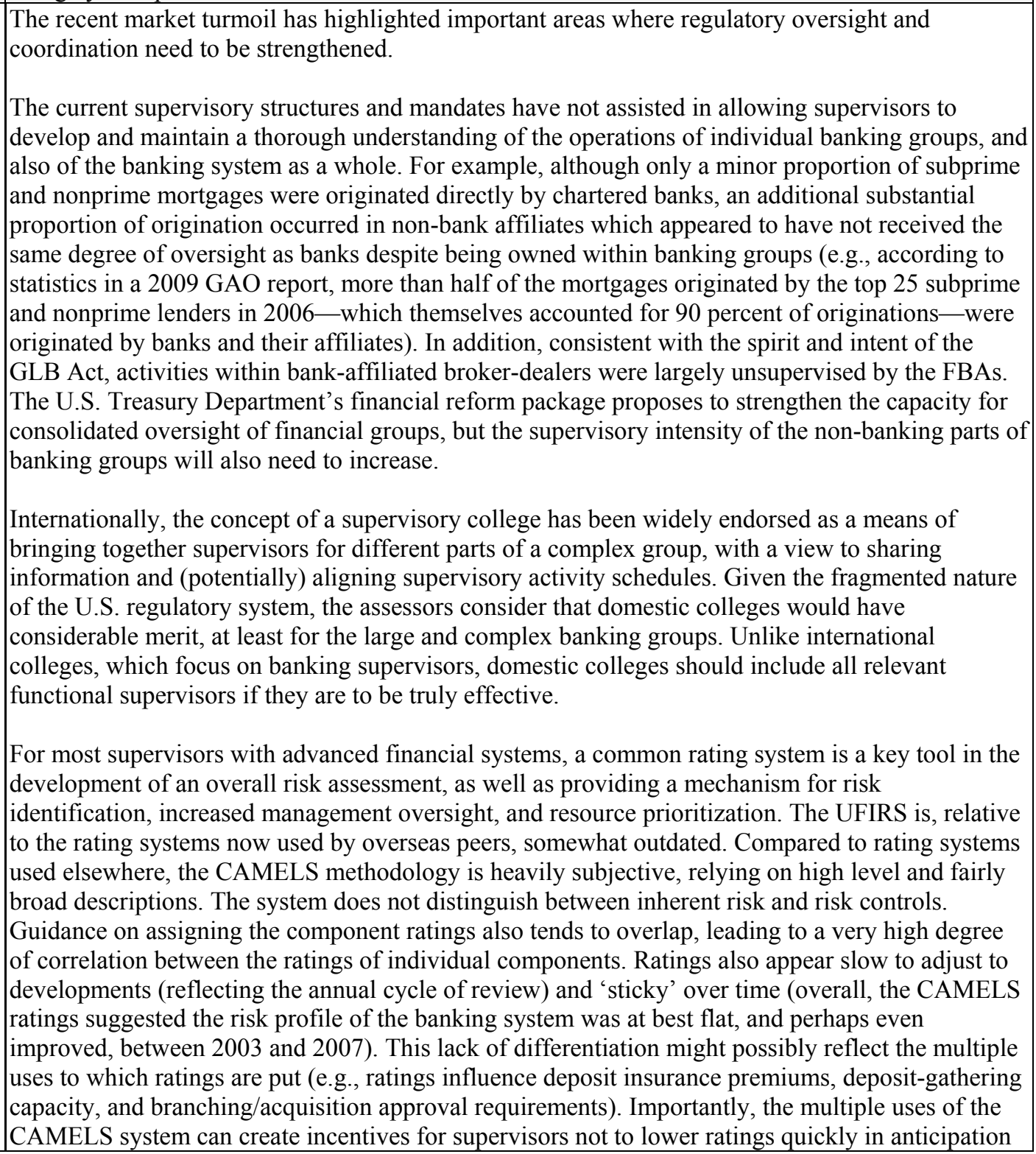 \\
\hline
\end{tabular}




\begin{tabular}{|c|c|}
\hline & $\begin{array}{l}\text { of potential problems. } \\
\text { The FBAs consider that the UFIRS and their own risk rating systems serve two distinct purposes } \\
\text { and, when combined, provide more complete information than either would provide individually } \\
\text { about the condition and evolution of the industry. However, it is not clear why this information } \\
\text { cannot be conveyed in a single measure and, in any event, the supplementary risk rating systems } \\
\text { differ by agency and are not readily comparable. The assessors recommend that either (i) the } \\
\text { UFIRS be overhauled, building on the good work that has been done by individual agencies in } \\
\text { developing their own more granular and risk-based rating systems, or (ii) that, if the FBAs consider } \\
\text { the UFIRS is too embedded in the broader regulatory system to be easily changed, greater effort be } \\
\text { directed to developing a consistent, more granular, forward-looking risk rating system that at least } \\
\text { provides a 'common language' across the FBAs. }\end{array}$ \\
\hline Principle 20. & $\begin{array}{l}\text { Supervisory techniques. An effective banking supervisory system should consist of on-site and } \\
\text { off-site supervision and regular contacts with bank management. }\end{array}$ \\
\hline Description & 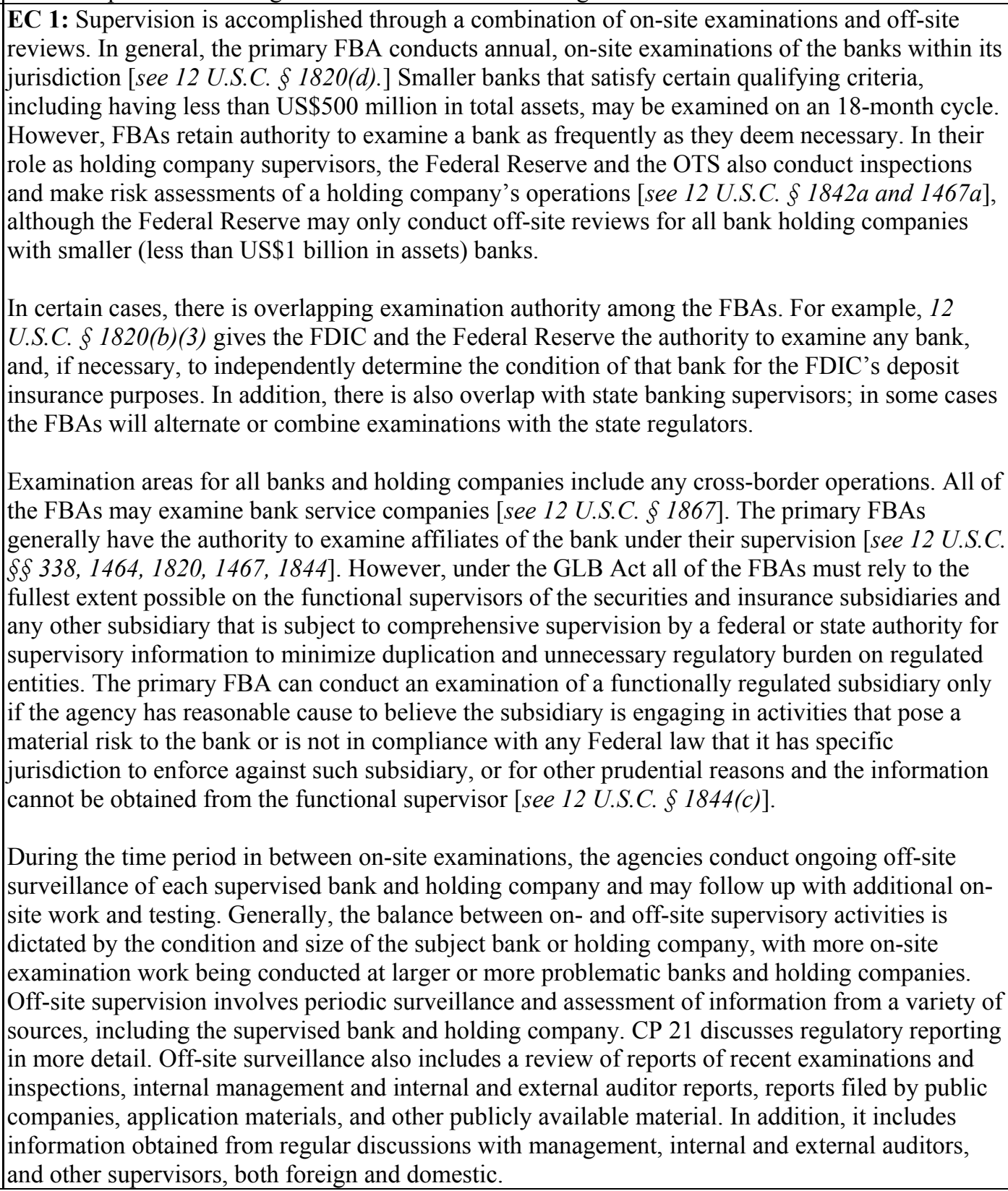 \\
\hline
\end{tabular}


The primary FBA makes risk assessments with respect to the bank's operations. For larger banks and holding companies, the FBA maintains resident on-site supervisors who provide continuous supervision of the banking organization and at least quarterly updates on the banks and holding company's condition and risk. Each agency has the authority to take an enforcement action if, in the agency's opinion, the bank, holding company or any institution-affiliated party (IAP) is engaging in an unsafe or unsound practice, or is violating the law [see 12 U.S.C. $\$ \$ 1813$ and $1818]$.

The FBAs have all implemented quality assurance programs designed to monitor the success of their on- and off-site supervisory efforts. The agencies are also subject to considerable public scrutiny (primary by Material Loss Review reports of the respective Offices of the Inspector General) whenever an institution fails.

EC 2: Each of the FBAs maintains written guidance for planning and executing on-site and off-site activities. Generally, agencies develop on- and off-site examination strategies and goals based on the risk profile of the bank or holding company. Guidance can be found in each of the agencies' examination manuals. The guidance specifies the objectives and expected actions and outputs for these activities, and also details basic procedures for completing on-site reviews and implementing off-site surveillance programs. Coordination and information sharing between on- and off-site supervision functions is facilitated by formal off-site monitoring programs that trigger follow-up by the on-site function when banks and holding companies meet various screening thresholds. In addition, supervisory policies require the consideration of off-site monitoring results when supervisors are determining the scope and procedures of on-site reviews.

EC 3: The FBAs utilize on-site examinations extensively. These endeavor to address all key areas of a bank's and holding company's operations. Examinations incorporate independent verification of the effectiveness of risk management, internal controls, management reporting, and overall corporate governance. In addition, examination procedures may be directed to validating the reliability and accuracy of financial data reported to the agencies. Also, at each examination, supervisors evaluate any follow-up to supervisory concerns raised at prior examinations or as a result of off-site monitoring.

During on-site examinations, the FBAs review the most recent external auditor's assessment of the banks or holding company's financials and the work of the loan review function and internal audit. Typically, supervisors review audit testing of financial and Call Report reconcilements and accuracy.

EC 4: As part of formal, off-site monitoring programs, the FBAs use automated screening systems, regulatory reports, standardized financial reports detailing key financial ratios and measures, and public sources of financial information to monitor the performance and condition of supervised banks and holding companies and promptly identify those requiring heightened supervisory attention. Supervisors periodically (e.g., quarterly) communicate with the bank's or holding company's management to discuss emerging issues or concerns. Examination staffs also use offsite surveillance tools and reports to plan the scope of, and determine priorities for, on-site examination work, as well as to monitor the progress in responding to matters requiring further attention.

EC 5: During the course of on-site examinations, the FBAs communicate regularly with the bank's and holding company's management, including heads of individual business units and control functions. At the conclusion of each examination, the supervisor will meet with the banks or holding company's management and board of directors to discuss findings and any significant issues found and to obtain management's and board's commitment to correct any weaknesses noted. The agency also provides the banks or holding company's board of directors a written RoE for review by all directors and senior officers. The RoE conveys the overall condition and risk profile of the bank and provides conclusions on the assigned supervisory CAMELS ratings; 


\begin{tabular}{|c|c|}
\hline & 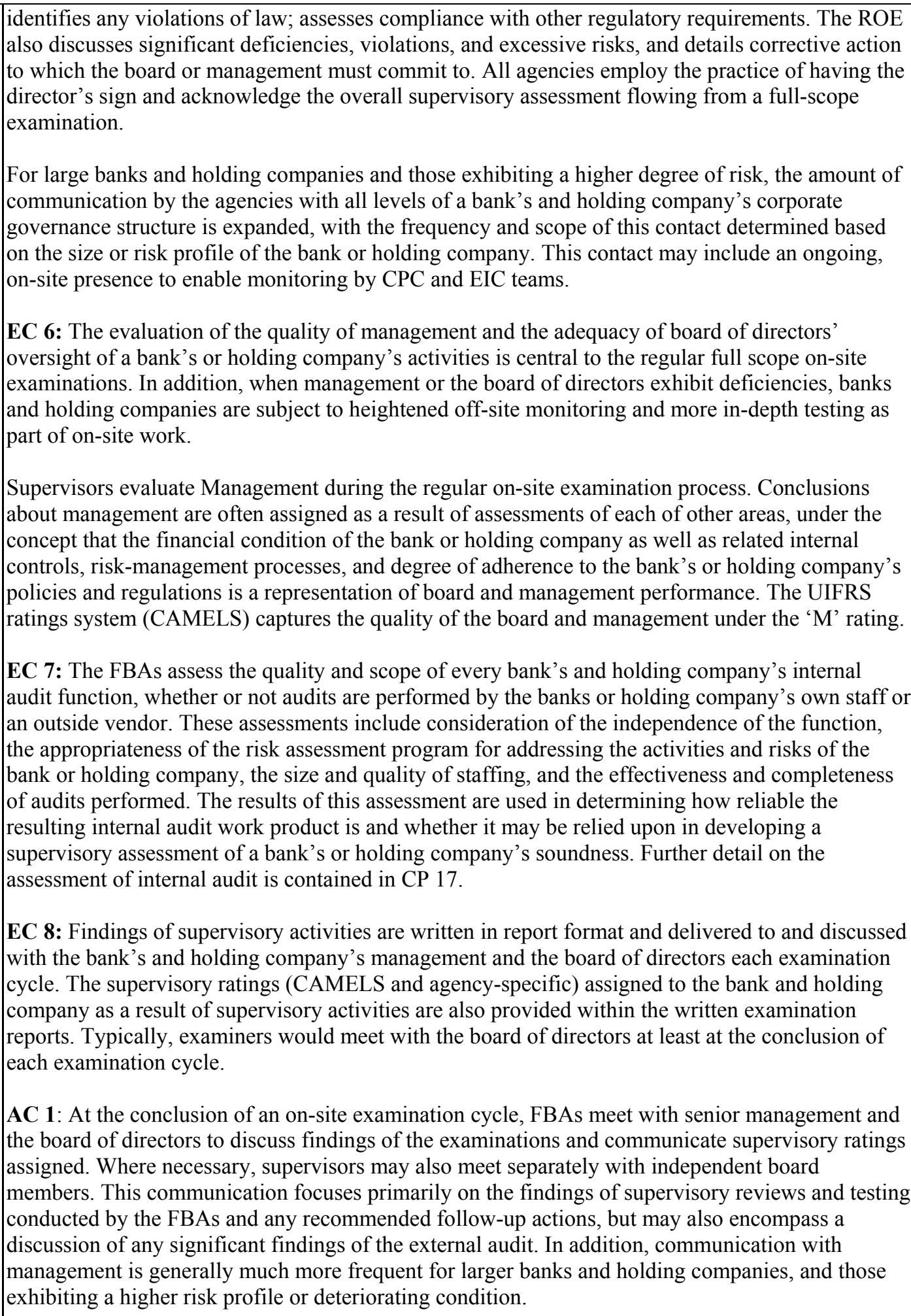 \\
\hline Assessment & Compliant \\
\hline Comments & $\begin{array}{l}\text { Individually, each of the FBAs employs standard supervisory techniques in a broadly consistent } \\
\text { manner. Each agency supplies its supervisory staff with extensive manuals, guidance and other } \\
\text { assessment mechanisms which supervisor can use to develop their assessments and judgments. }\end{array}$ \\
\hline
\end{tabular}




\begin{tabular}{|c|c|}
\hline & $\begin{array}{l}\text { These appear well embedded in each agency's practices. } \\
\text { There are, however, areas where the agencies could improve consistency between their operating } \\
\text { processes, designed to develop a 'best of breed' model for supervision. There appear to be } \\
\text { unnecessary differences in examination manuals, each agency uses (as noted in CP 19) } \\
\text { supplementary assessments and rating systems designed to support the CAMELS framework, and } \\
\text { different off-site surveillance models. The assessors have not been able to form a complete } \\
\text { judgment in the time available on the extent to which they impact on the evenness of supervision } \\
\text { applied to banks under various regulators but the scope for inconsistent practices and therefore } \\
\text { inconsistent risk assessments undoubtedly exists. } \\
\text { The FFIEC has been established to promote uniformity in the supervision of financial institutions. } \\
\text { In general, most significant supervisory guidelines, policies and rules are developed and issued on } \\
\text { an interagency, collaborative basis. This work is often facilitated through various work groups and } \\
\text { task forces within the FFIEC. However, the FFIEC, and the agencies it represents, could perhaps } \\
\text { consider a stocktaking of existing supervisory manuals and guidance with a view to eliminating } \\
\text { unnecessary differences and promoting good practice across all agencies. }\end{array}$ \\
\hline Principle 21. & $\begin{array}{l}\text { Supervisory reporting. Supervisors must have a means of collecting, reviewing and analyzing } \\
\text { prudential reports and statistical returns from banks on both a solo and a consolidated basis, and a } \\
\text { means of independent verification of these reports, through either on-site examinations or use of } \\
\text { external experts. }\end{array}$ \\
\hline Description & 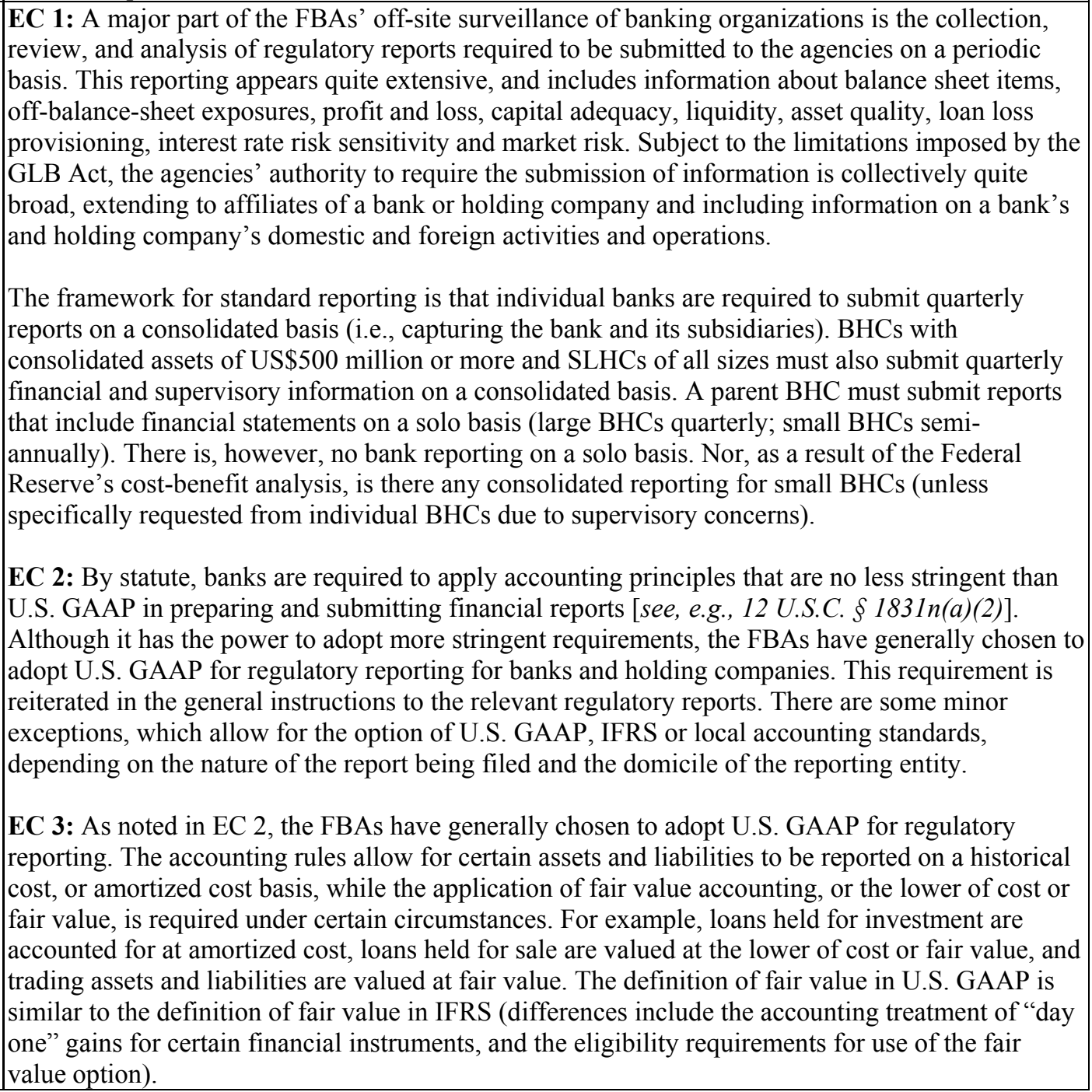 \\
\hline
\end{tabular}


EC 4: The FBAs collect and analyze information quarterly from all banks, bank holding companies with consolidated assets of US\$500 million or more, and SLHCs of all sizes. If the BHC is below the US\$500 million threshold, then it submits a parent-only report on a semiannual basis. In addition, reports from other subsidiaries, such as non-bank subsidiaries, in the BHC are required to be submitted either quarterly or annually, depending of the size and nature of the subsidiary.

At large banks or holding companies where the FBAs have continuous on-site examination teams, supervisors receive frequent risk management reports that allow them to monitor the bank's or holding company's condition and trends in key portfolios and risk segments. Similarly, the agencies may direct individual banks and holding companies to provide information on a more frequent basis, depending on their risk profile. An example has been daily liquidity reporting which has been instituted for key institutions during the financial crisis.

EC 5: The FBAs collect reports on the same dates for all entities in the consolidated holding company. While the frequency may differ given the size and nature of the entity, the reporting dates are as of the calendar quarter end. Banks and holding companies are required to complete reports using a standard set of reporting instructions, thereby ensuring comparability of reported items between banks and holding companies.

The agencies also work together to ensure, to the extent possible, that the information reported at the subsidiary level is comparable to information that is collected at the consolidated holding company level. Under the auspices of the FFIEC, the FBAs meet during the year to determine what revisions, if any, need to be made to regulatory reports. Revisions are usually made during the first calendar quarter of the following year, although in some circumstances changes to regulatory reports may be implemented at other times.

EC 6: Collectively, the FBAs have broad statutory authority to obtain a broad array of information from supervised banks and holding companies (see CP 1(4), EC 2). Banks and holding companies must provide supervisors with full and complete access to their books, records, and employees (including directors); failure to do so can result in the imposition of administrative sanctions.

Under their statutory authorities, the FBAs have the power to request and receive any relevant information from banks and holding companies, irrespective of their activities, where the supervisor believes that it is material to their financial situation, or to the assessment of the risks of the bank or holding company. This includes internal management information [see, e.g., 12 U.S.C. $\S 161$ (a) and (c)]. However, this authority is limited by the GLB Act requirement that the FBAs must rely to the fullest extent possible on the functional supervisors of the securities and insurance subsidiaries and any other subsidiary that is subject to functional supervision by a federal or state authority [see, e.g., 12 U.S.C. $\$ \$ 1831 v$ and $1844(c)(2)(E)$.]

EC 7: The FBAs have the authority to review all books and records of a bank or holding company that are deemed necessary for supervisory purposes. The agencies have access to the banks or holding company's board, management, and staff when required to discuss supervisory matters. Furthermore, the agencies have the authority to require a bank or holding company to submit any information if there is a supervisory need, even when a particular bank or holding company would not be otherwise required to submit such information.

EC 8: Banks and holding companies are required by statute to comply with reporting requirements and information disclosure requests of FBAs. A failure to comply (including by submitting an untimely report or for misreporting or persistent errors) can provide the basis for informal or formal enforcement measures. Under certain circumstances, a culpable IAP (i.e., related party) also may be subject to suspension and debarment [see, e.g., 12 U.S.C. $\$ \S 1817(a)$ and 1818(b) and (i)]. The agencies can require banks and holding companies to amend previously filed reports when material errors have occurred, although the OTS typically adopts an approach of not seeking 


\begin{tabular}{|c|c|}
\hline & 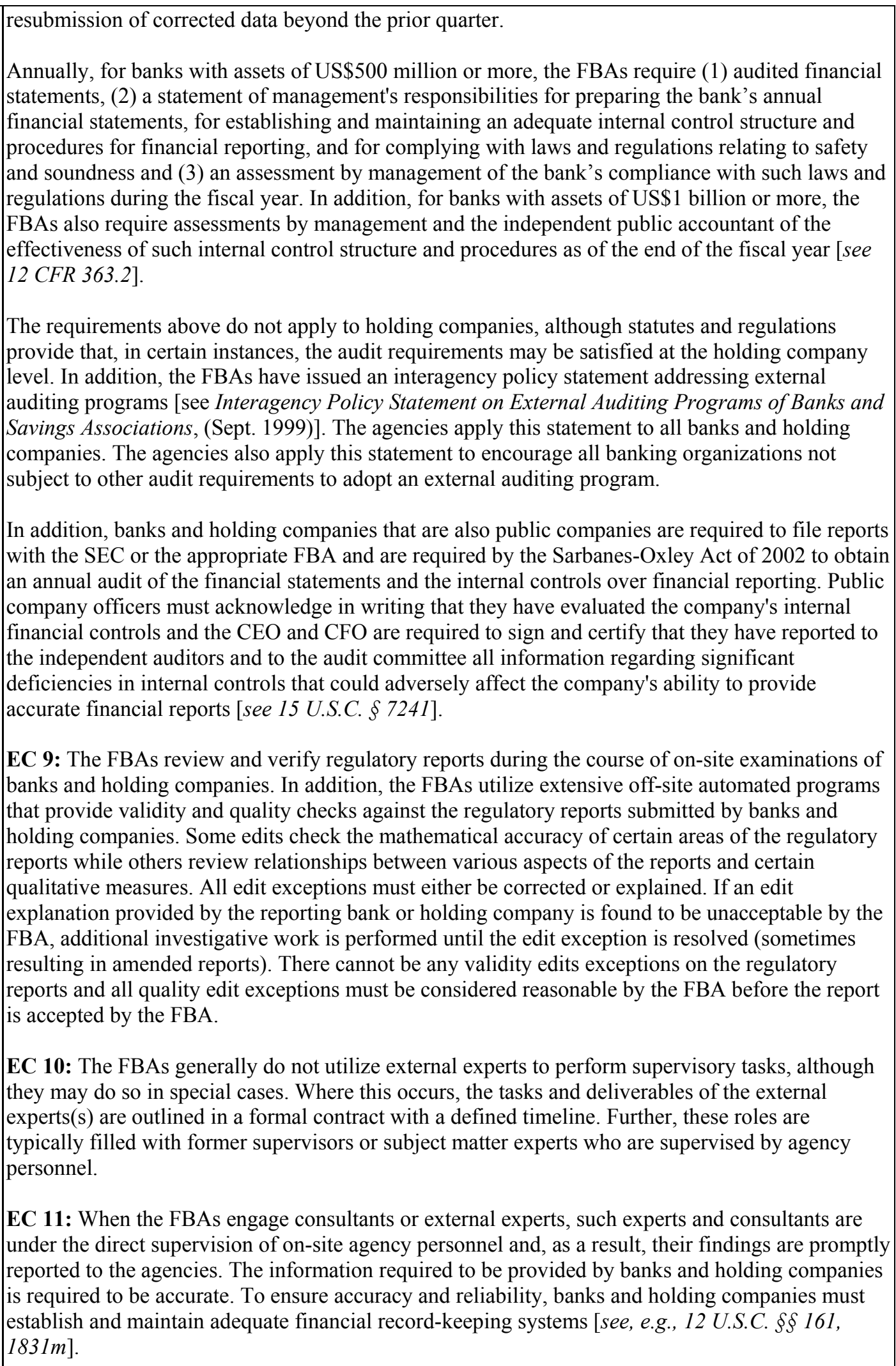 \\
\hline Assessment & Compliant \\
\hline Comments & principle, although the assessors noted some areas where \\
\hline
\end{tabular}




\begin{tabular}{|c|c|}
\hline & 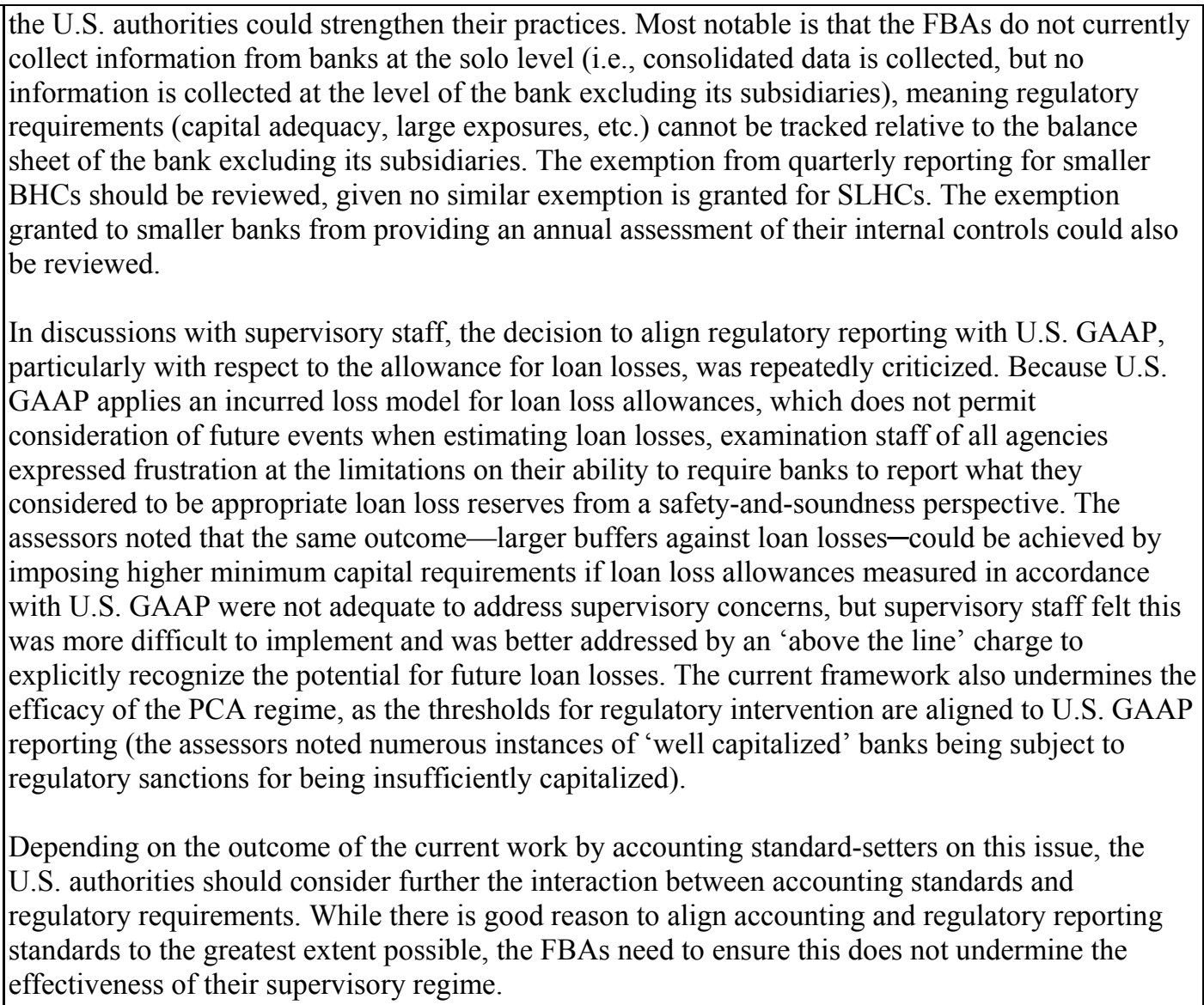 \\
\hline Principle 22. & $\begin{array}{l}\text { Accounting and disclosure. Supervisors must be satisfied that each bank maintains adequate } \\
\text { records drawn up in accordance with accounting policies and practices that are widely accepted } \\
\text { internationally, and publishes, on a regular basis, information that fairly reflects its financial } \\
\text { condition and profitability. }\end{array}$ \\
\hline Description & 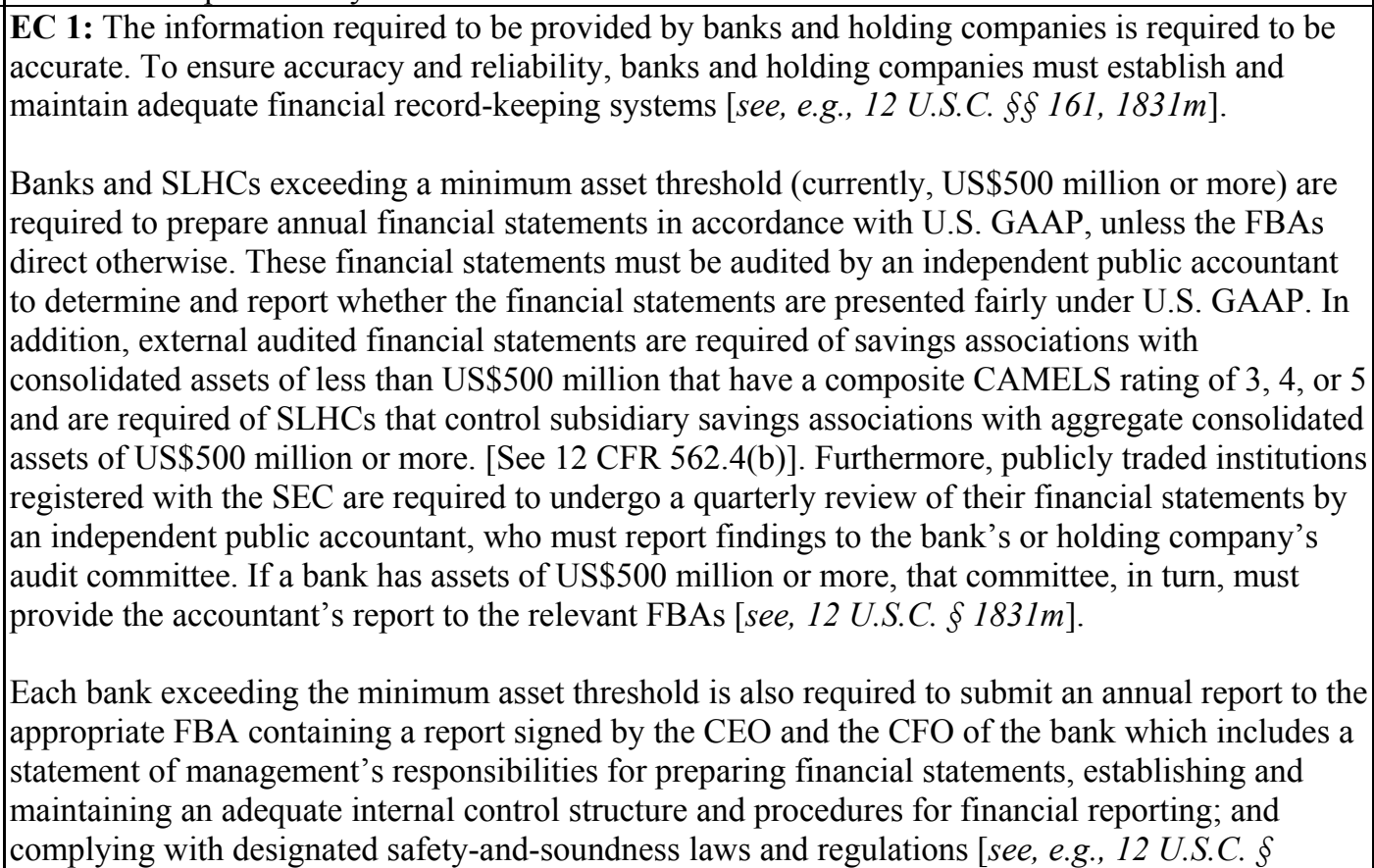 \\
\hline
\end{tabular}


$1831 \mathrm{~m}(\mathrm{~b})(2)$ and 12 CFR 363.2(b)]. The report must include (i) an assessment by management of the bank's compliance with the designated safety-and-soundness laws and regulations during the fiscal year and (ii) for banks with assets of US\$1 billion or more, assessments by management and the independent public accountant of the effectiveness of such internal control structure and procedures as of the end of the fiscal year.

The requirements above do not apply to holding companies, although statutes and regulations provide that, in certain instances, the audit and reporting requirements may be satisfied at the holding company level. In addition, the FBAs have issued an interagency policy statement addressing external auditing programs, which recommends that boards of directors establish and maintain such programs [see Interagency Policy Statement on External Auditing Programs of Banks and Savings Associations, (Sept. 1999)]. The agencies apply this statement to all banks and holding companies. The agencies apply also this statement to encourage all banking organizations not otherwise subject to an audit requirement to have an external audit of the financial statements.

EC 2: The FBAs require independent external audits of annual financial statements and related internal controls based on prescribed asset-size thresholds, regardless of whether the bank is public or non-public. Banks and holding companies that are publicly registered also must comply with SEC requirements, including the Sarbanes-Oxley Act, to obtain an annual audit of the financial statements and the internal controls over financial reporting and are subject to the SEC's reporting requirements, including public reporting of quarterly and annual financial reporting. The audited annual financial statements, as well as quarterly financial statements, are subject to CEO and CFO certification and are made publicly available by the SEC for public holding companies and by the FBAs for certain banks.

The FBAs require banks and holding companies to file accurate financial reports including financial statements and reports of condition. Some of these reports, for both public and non-public banks and holding companies, are made public by the FBAs. Such financial reports are required to be certified by the bank's or holding company's CFO and a specified number of directors (trustees).

EC 3: The accounting principles applicable to reports or statements required to be filed with the FBAs by all banks and holding companies are uniform and must be consistent with, or no less stringent than, U.S. GAAP. The FBAs issue reporting instructions for required regulatory financial reports. Those reporting instructions require, amongst other things, that banks and holding companies report pre-tax income net of the provision for loan and lease losses. As with the IASB, the FASB is reviewing its accounting standards in light of the lessons learned from the recent financial crisis.

EC 4: In general, external auditors must determine and report whether the financial statements of certain banks are presented fairly in accordance with U.S. GAAP. Further, the external audits must meet or exceed the scope and procedures required by generally accepted auditing standards (GAAS) [see 12 U.S.C. $\$ 1831 \mathrm{~m}$ ]. Supervisory discretion to establish the scope and standards of an external audit of an individual bank is available in circumstances where 12 USC $\S 181$ applies, e.g., unsafe or unsound practices.

EC 5: External audits are required to meet or exceed the scope and procedures required by GAAS. External audits may have to comport with additional requirements, as determined by regulation, guideline, guidance, or other related materials. As noted above, the FBAs require certain banks and holding companies to obtain annual audits of financial statements performed in accordance with GAAS and external audits of internal controls over financial reporting. Financial statement audits cover areas such as loans, allowance for loan losses, and asset valuations as appropriate to enable the auditor to provide an opinion on whether the financial statements as a whole are presented fairly in accordance with U.S. GAAP. The FBAs reported that approximately 97 percent of consolidated assets of U.S. bank holding companies were audited as of year-end 2007. 
For a smaller bank not subject to the audit requirements, a non-audit agreed-upon procedures engagement is commonly used. Alternatively, an attestation engagement may be performed for all internal controls relating to the preparation of annual financial statements or specified schedules of the bank's regulatory reports. This type of engagement is performed under generally accepted standards for attestation engagements.

EC 6: The FBAs may remove, suspend, or bar an independent public accountant, upon a showing of good cause, from performing the required audit services for a bank [see 12 U.S.C. $\$ 1831 \mathrm{~m}(\mathrm{~g})(4)$ and 12 CFR 19.243]. "Good cause" would exist, for example, when the external auditor is determined to have inadequate expertise or independence or not to be subject to or follow established professional standards. Each bank exceeding the minimum asset threshold or registered with the SEC is required to provide the appropriate $\mathrm{FBA}(\mathrm{s})$ with notice of the engagement, and the resignation or dismissal, of an independent public accountant (and must include a statement of the reason for resignation/dismissal). An independent public accountant must also notify the appropriate FBA(s) if its services are terminated, and the reasons for the termination [see 12 CFR $363.4(d)$ and $363.3(c)]$.

In the US, the supervisors may review the audit work papers. If a supervisor concludes, based on the review of the specific work performed, discussions with the audit firm, or other documentation, that the external auditor does not have the requisite expertise, independence, or does not follow established professional standards, the supervisor discusses these findings and the actions the agency may take with the bank's senior management, board of directors (or audit committee), and the external auditor. If the issue cannot be resolved, then the FBA can bar the accountant from performing further audits.

EC 7: Banks and SLHCs that exceed the minimum asset threshold (currently US $\$ 500$ million) are required to obtain an independent external audit of their annual financial statements. Annual financial statements must be prepared in accordance with U.S. GAAP and external audits must be performed in accordance with GAAS [see 12 U.S.C. $\$ 1831 \mathrm{~m}$ and 12 CFR 363.2 and 363.3]. External audited financial statements are required of savings associations with assets less than US\$500 million that have a composite CAMELS rating of 3, 4, or 5 and of SLHCs that control subsidiary savings associations with aggregate consolidated assets of US\$500 million or more. [see 12 CFR 562.4(b)]. Otherwise, non-public banks under the prescribed threshold generally are not required to produce audited financial statements, but nonetheless need to provide reliable information on their financial position to the FBAs, who make such information public. Public banks and holding companies are also subject to SEC disclosure requirements, including in relation to audited financial statements.

EC 8: The FBAs require the periodic public disclosure of information by banks and holding companies that adequately reflect their financial condition. The disclosure requirements are broadly applicable, subject to uniform submission deadlines, and ensure the timeliness and relevance of information. Uniform requirements ensure comparability of information. Accuracy and reliability are ensured by separate requirements regarding the adequacy of financial record-keeping systems; adherence to these requirements is reinforced by the specter of substantial remedial consequences for submitting misleading or false information.

Furthermore, banks and holding companies registered with the SEC or the appropriate FBA under the federal securities laws have additional quarterly and annual financial reporting and disclosure requirements. The FBAs review regulatory reports on a periodic basis and if the agencies determine that the information or disclosures are incorrect, they may require that the bank or holding company restate regulatory reports. Information in regulatory reports may differ from that required in audited financial statements.

EC 9: U.S. GAAP provides guidance on financial reporting and disclosure matters, including qualitative and quantitative information. Financial reports of publicly traded banks and holding companies include financial statements with all U.S. GAAP disclosures and Management's 


\begin{abstract}
Discussion and Analysis.
Regulatory reports (such as the Call Report, TFR, and the FR Y-9C) consider the size and complexity of a bank's or holding company's operations in the scope and content of required information and the commensurate level of disaggregation and detail. For example, banks with a significant amount of trading activity (trading assets and trading liabilities that exceed a prescribed threshold) are required to complete a detailed trading schedule. In addition, some of the regulatory reports provide the opportunity for the reporting banks to provide footnotes or narrative disclosures, which may be either quantitative or qualitative in nature.
\end{abstract}

EC 10: The statutes require that banks comply with reporting requirements and information disclosure requests of the FBAs. Failure to comply can provide the basis for informal or formal enforcement measures [see 12 U.S.C. $\$ \$ 1813(u), 1817$, and 1818].

The SEC has the primary responsibility for ensuring review of public disclosures of public holding companies and for taking enforcement action, as necessary. The appropriate FBA has this responsibility for public banks. The SEC coordinates with the appropriate FBA on enforcement matters affecting public holding companies. The Public Company Accounting Oversight Board (PCAOB) reviews the auditors of public companies to ensure that the auditors comply with prescribed auditing and ethics standards.

EC11: For each bank, the FBAs publish Uniform Bank Performance Reports (UBPR) and the OTS publishes the Uniform Thrift Performance reports (UTPR), which are primarily based on the information reported on the Call Reports and TFRs. These reports are also made publicly available by the FBAs, and include various indicators and ratios involving financial position, financial performance, and capital for each bank and its peer group, including deposit composition and stability, ratios of loan commitments to total loans and of standby letters of credit to total loans, the loan-to-deposit ratio (at community banks), the ratio of temporary investments to volatile liabilities, and the ratio of pledged securities to total securities. A similar report is produced by the Federal Reserve for aggregated BHC information, the Bank Holding Company Performance Report (BHCPR).

AC 1: The FBAs meet periodically with external audit firms as well as the FASB, American Institute of Certified Public Accountants (AICPA) and the PCAOB to discuss accounting, audit, and financial disclosure issues related to banks and holding companies. Supervisors also meet periodically with external audit firms with respect to individual banks and holding companies to discuss general and specific issues with respect to their accounting and disclosure practices. In addition, external auditors will typically ask to speak to the supervisors before signing off on annual financial statements to ensure that the supervisors do not have information that would preclude their sign-off.

AC 2: There is no statutory obligation on auditors to report matters to the FBAs, nor any associated protection for auditors should they seek to do so. Auditors of public companies are required to file reports with the SEC if company management fails to take remedial action, however, and are protected from liability related to doing so. [see 15 U.S.C. § 78j-1(b) \& (c)]. As a backstop, supervisors review communication to management and the audit committee made by the external auditors. Supervisory guidance gives federal banking supervisors access to communications between the auditor and the bank client. In addition, FBAs have the authority to review auditors' workpapers.

AC 3: It is unlawful for a registered public accounting firm to provide audit services to an issuer if the lead (or coordinating) audit partner responsible for the audit, or the audit partner responsible for reviewing the audit, has performed audit services for that issuer in each of the 5 previous fiscal years of that issuer [see 15 U.S.C. $\$ 78 j-1]$.

In addition to the five-year rotation requirement of the lead and concurring audit partners, the SEC 


\begin{tabular}{|c|c|}
\hline & $\begin{array}{l}\text { has adopted rules that also mandate a five-year "timeout" period after rotation. The rules specify } \\
\text { that certain other significant audit partners will be subject to a seven-year rotation requirement with } \\
\text { a two-year "timeout" period. There are minor exceptions for small audit firms. } \\
\text { Auditors of banks with assets of US } \$ 500 \text { million or more are required to satisfy the independence } \\
\text { requirements of the SEC, PCAOB and AICPA. For smaller non-public banks that are not otherwise } \\
\text { required to have an annual independent audit, an external auditor must meet only the AICPA } \\
\text { independence standards. } \\
\text { AC 4: There is no explicit requirement for non-public banks to have a formal disclosure policy, } \\
\text { although it will be expected in those banks adopting the Advanced approaches under Basel II. } \\
\text { More broadly, a bank is required to have an appropriate governance and control structure over the } \\
\text { preparation of financial reporting and disclosures. This includes properly approved written policies } \\
\text { that provide clear guidelines on accounting and disclosure matters, consistent with U.S. GAAP and } \\
\text { the bank's regulatory requirements. } \\
\text { AC 5: External auditors of large banks are required to agree to provide related audit working } \\
\text { papers, policies, and procedures to supervisors, if requested [see } 12 \text { U.S.C. } \$ 1831 m(G)(3)(a)] \text {. As } \\
\text { a matter of best practice, supervisors expect all banks, regardless of asset size, to obtain agreement } \\
\text { of an independent public accountant or other external auditor in the engagement letter to grant } \\
\text { supervisors access to all the accountant's or auditor's work papers and other material pertaining to } \\
\text { the bank prepared in the course of performing the completed external auditing program [see the } \\
\text { Interagency Policy Statement on External Auditing Programs of Banks and Savings Institutions]. }\end{array}$ \\
\hline Assessment & Compliant \\
\hline Comments & $\begin{array}{l}\text { Many countries provide for a statutory obligation on the external auditors of banks to promptly } \\
\text { advise the bank supervisor should they encounter any issues during the course of the audit work } \\
\text { which could potentially represent a risk to the safety and soundness of the bank. This obligation is } \\
\text { typically accompanied by an associated statutory protection ('whistleblower' protection) for such } \\
\text { reporting. The authorities should consider the merits of introducing a similar regime for reporting } \\
\text { directly to bank supervisors in the U.S. }\end{array}$ \\
\hline Principle 23. & $\begin{array}{l}\text { Corrective and remedial powers of supervisors. Supervisors must have at their disposal an } \\
\text { adequate range of supervisory tools to bring about timely corrective actions. This includes the } \\
\text { ability, where appropriate, to revoke the banking license or to recommend its revocation. }\end{array}$ \\
\hline Description & $\begin{array}{l}\text { EC 1: Generally, the FBAs identify problems during on-site and off-site examinations. Most issues } \\
\text { are solved informally during the examination (or in the ongoing discussions between the bank and } \\
\text { the EIC/ CPC where relevant), when the bank or holding company takes steps to address the } \\
\text { regulatory concerns. At the conclusion of the examination the supervisors send an ROE to the bank } \\
\text { for review by all directors and senior officers. The ROE assesses conditions of the "CAMELS" } \\
\text { components, identifies violations of law, assesses compliance with the Bank Secrecy Act, } \\
\text { consumer laws, and the Community Reinvestment Act. The narrative of the ROE also calls } \\
\text { attention to other matters that need to be dealt with (e.g., MRA = Matters Requiring Attention). } \\
\text { Some problems, especially if serious, pervasive or repeated, may need to be addressed through } \\
\text { formal supervisory action, which always is expressed in a written document from the supervisors. } \\
\text { All formal supervisory actions are publicized, at a minimum, on a monthly basis (with exceptions } \\
\text { only in very specific circumstances such as when publication would be contrary to the public } \\
\text { interest). Detailed policies and action plans with specific target dates may be requested from a bank } \\
\text { or holding company, and supervisors will review the institution's board's plan for sufficiency and } \\
\text { examine written progress reports by the bank, against key milestone dates. Progress will also be } \\
\text { assessed through ad hoc or normal onsite examinations. } \\
\text { EC 2: The FBAs have authority to appoint a conservator or receiver under a variety of } \\
\text { circumstances, including when the bank is critically undercapitalized or is undercapitalized and has } \\
\text { no reasonable prospect of becoming adequately capitalized; is unable to meet depositors' demand } \\
\text { for payment or is operating in an unsound or unsafe condition that would likely cause insolvency or } \\
\text { substantially dissipate the bank's assets. By law, the FDIC is always appointed the receiver for }\end{array}$ \\
\hline
\end{tabular}


closed insured banks.

EC 3: The FBAs have a range of supervisory options when a bank or holding company is not complying with laws, regulations or supervisory decisions, or is engages in an unsafe and unsound practices. The agencies may take prompt remedial action and impose penalties. The range of tools is applied in accordance with the gravity of the situation. If there are serious or repeated deficiencies, or when management has not acted sufficiently on an informal request, the agencies may take formal enforcement action. Such actions include: (i) Formal agreements; (ii) Cease and Desist Orders; (iii) Safety and Soundness Orders (iv) Capital Directives; (v) PCA directives; and (vi) Civil Money Penalty Assessments. Formal enforcement actions are legally enforceable and remain in effect until modified or terminated. See 12 U.S.C. $\$ 1818(u)$. In cases where there is an immediate threat to the bank or holding company or to the depositors' interests, an agency may take immediate action by issuing a temporary order to cease and desist.

EC 4: Possible remedial measures include restricting the current activities or operations; withholding or conditioning approval of new activities or acquisitions; restricting or suspending payments to shareholders or share repurchases; restricting asset transfers; barring individuals from banking; replacing or restricting the powers of managers, board directors or controlling owners; facilitating a takeover by, or merger with, a healthier bank; providing for the interim management of the bank; and revoking the bank license. The selection of an enforcement actions typically aim at the bank's specific problems or deficiencies. Common provisions require the bank to cure specified violations, correct risk management or board of director oversight weaknesses, submit a plan to increase or maintain capital, provide for an adequate allowance for loan and lease losses, employ qualified officers and employees, and restrict the payment of dividends. The agencies have power to place a bank into conservatorship or to close a bank under a variety of circumstances.

EC 5: A PCA regime applies to those instances in which a bank's capital falls below the prescribed minimum ratios. The regime provides a backstop against regulatory forbearance. For example, a bank that is less than adequately capitalized must not pay dividends and must submit a capital restoration plan. The PCA regime provides for mandatory as well as discretionary actions by the supervisors [for more details see EC 6 under Principle 6]. In addition, 12 U.S.C. $\$ 3907$ requires FBAs to "achieve and maintain capital," e.g., by establishing minimum capital levels on a case-bycase basis for individual banks, e.g., to reflect higher risks such as from higher risk concentrations or poor risk management systems. The agencies also have powers to intervene even before the minimum capital ratio is breached, for example when loan quality reviews indicate a need to maintain capital above the statutory minimum. As an indicator of timely actions by the authorities, the rapid resolution of some major banks (and non-banks) during the present crisis can be noted.

EC 6: Remedial penalties and sanctions may be applied to banks and holding companies and, when appropriate, to management, board members, employees and other individuals who participate in a bank's or holding company's affairs (Institution-Affiliated Partners, or IAPs)

AC 1: The PCA statute sets out clear triggers for mandatory and discretionary supervisory actions. Hence, an undercapitalized bank must submit a capital restoration plan within 45 days and the agency must review the plan within 60 days and determine if it is acceptable. A critically undercapitalized bank must be closed within 90 days according to the PCA. Aside from PCA, there are no specific statutory requirements that establish timetables for supervisory action. Individual FBAs have recently implemented stricter time limits— such as 45 days for normal cases and 60 days for cases involving supervisory actions - for the completion of the onsite examination and the agency's consideration of the examination report, including, when relevant, taking supervisory action.

AC 2: The FBAs have the authority to impose conditions on the relationship between a bank and any other entity in order to prevent or address a threat to the safety and soundness of the bank. For example, actions may limit or prohibit payments from a bank to its holding company or affiliates. 


\begin{tabular}{|c|c|}
\hline & $\begin{array}{l}\text { AC 3: The Federal Reserve and the OTS, as the "umbrella supervisors" of holding companies and } \\
\text { their subsidiaries, rely on the federal and state supervisors of functionally regulated subsidiaries to } \\
\text { examine those subsidiaries and take supervisory action when appropriate. Where possible, the } \\
\text { Federal Reserve and the OTS coordinate their actions and share information with other U.S. } \\
\text { supervisors, foreign supervisors and with other functional supervisors to effect supervisory action } \\
\text { and reduce regulatory redundancies. }\end{array}$ \\
\hline Assessment & Compliant \\
\hline Comments & $\begin{array}{l}\text { In many cases supervisors, while adhering to regulations and supervisory guidelines, will assess } \\
\text { banks as being capital deficient and will require an infusion of capital, while at the same time the } \\
\text { bank is defined as "well capitalized" under the definitions of the PCA. This dichotomy (which has } \\
\text { been discussed more fully in CP 21) weakens the credibility of enforcement actions and should be } \\
\text { rectified. }\end{array}$ \\
\hline Principle 24. & $\begin{array}{l}\text { Consolidated supervision. An essential element of banking supervision is that supervisors } \\
\text { supervise the banking group on a consolidated basis, adequately monitoring and, as appropriate, } \\
\text { applying prudential norms to all aspects of the business conducted by the group worldwide. }\end{array}$ \\
\hline Description & 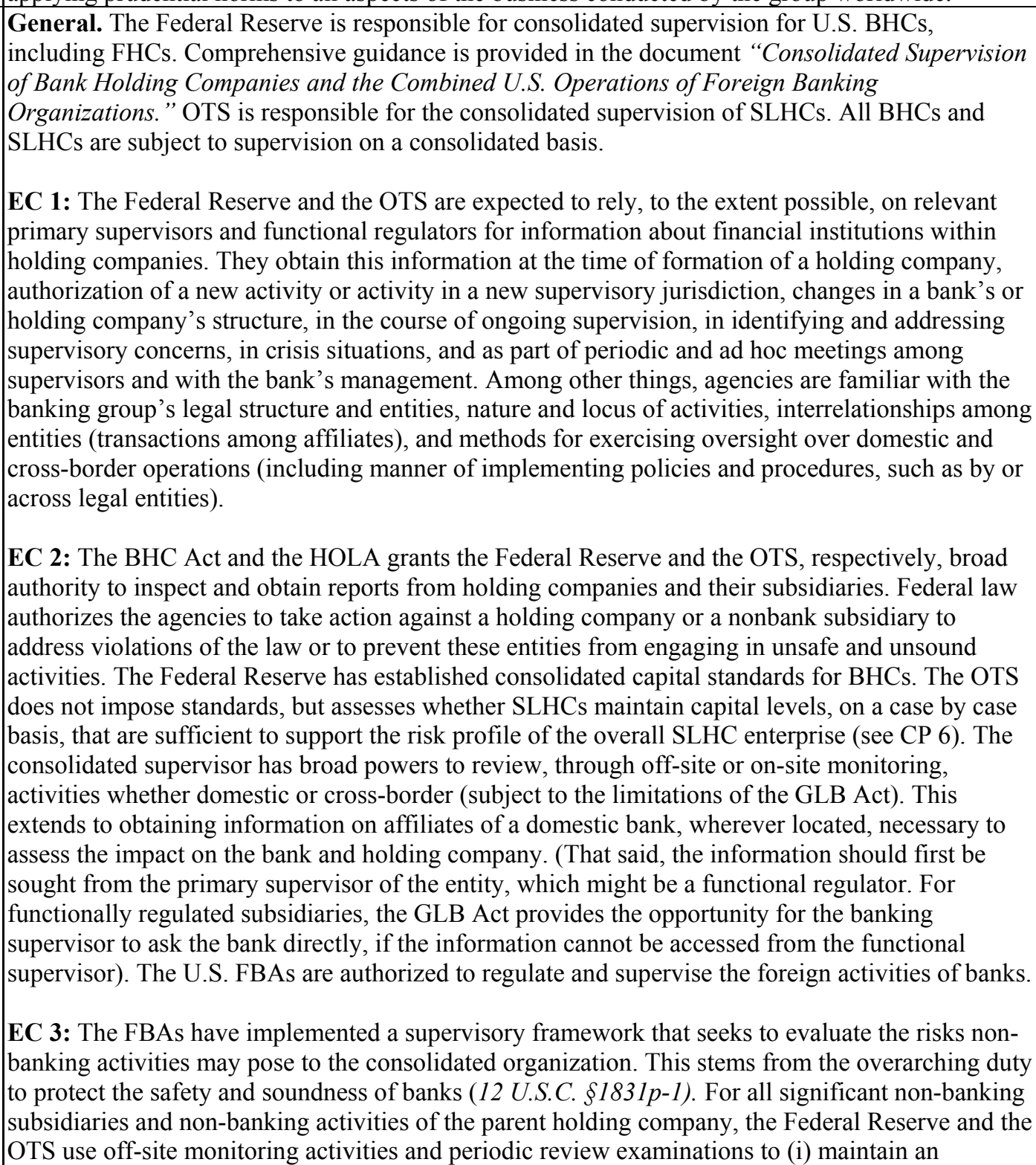 \\
\hline
\end{tabular}


understanding of operations, financial condition, inherent risks and risk-management practices and (ii) assess the adequacy of risk management and internal controls.

EC 4: There are no requirements for consolidated application, including the holding company level of large exposures limits, insider lending limits, general lending limits. However, through their onsite examinations supervisors monitor the aggregated volume of exposures, such as on large exposures, insider lending and general lending, on a risk-based basis adapted to the size and character of the business of the affiliates to determine that holding companies and non-bank affiliates in a group do not endanger the group.

EC 5: See Principle 1(6) on information-sharing both domestically with banking and functional regulators, and with foreign banking supervisors. Under these information-sharing arrangements, the FBAs may receive information on the financial condition and adequacy of risk management and controls of the different entities of the bank or holding company.

EC 6: As discussed under Principles 3, 23 and 25, the FBAs have the power, at authorization or as a remedial measure, to limit the range of activities a bank or holding company may conduct and the locations in which activities can be conducted. This is additional to the general legal restrictions, to which banks or holding companies are subjected. The supervisor uses this power to determine that the activities are properly supervised and that the safety and soundness of the bank is not compromised.

EC 7: An assessment of cross-border operations is incorporated into the evaluation of key corporate governance functions and primary firm-wide risk management and internal control functions. In some instances, privacy concerns have led to limits on information that can be shared by a foreign office with its parent holding company. In such cases, strong local internal controls and audit processes are particularly important. Constraints on providing information may lead to communications between the FBAs and host country supervisors.

EC 8: U.S. banks and holding companies are required to provide FBAs with specific information regarding their foreign operations and any other information that supervisors deem necessary to determine compliance with U.S. banking laws. Assessments of banks and banking organizations encompass the entirety of domestic and foreign operations. As noted under EC 7, the agencies evaluate key functions such as controls and systems, including audit and MISs, and effectiveness of management and board oversight across the organization. In addition, testing and verification procedures are performed in locations with the highest risk exposure. Accordingly, although there is not a separate and distinct requirement for assessing managers' oversight of foreign operations, in practice such oversight may occur when considered necessary, based on a risk-focused assessment.

EC 9: Where material impediments exist, the supervisors can take remedial measures, including imposing additional limits on foreign operations or requiring the closing of such operations. Such an impediment may exist when management oversight and/or supervision by the host supervisor is not adequate relative to the risks the foreign operations present, or when necessary information is not forthcoming.

EC 10: The agencies evaluate risk-management processes for bank activities across legal entities and perform testing procedures where the exposure or risk is greatest. In implementing this riskbased approach, the authorities may choose not to focus on a jurisdiction even though its supervisory regime may be different.

AC 1: The consolidated supervisors have the power to review the activities of parent holding companies and of companies affiliated with those. They also have the authority to evaluate the suitability of owners and senior management of holding companies. 


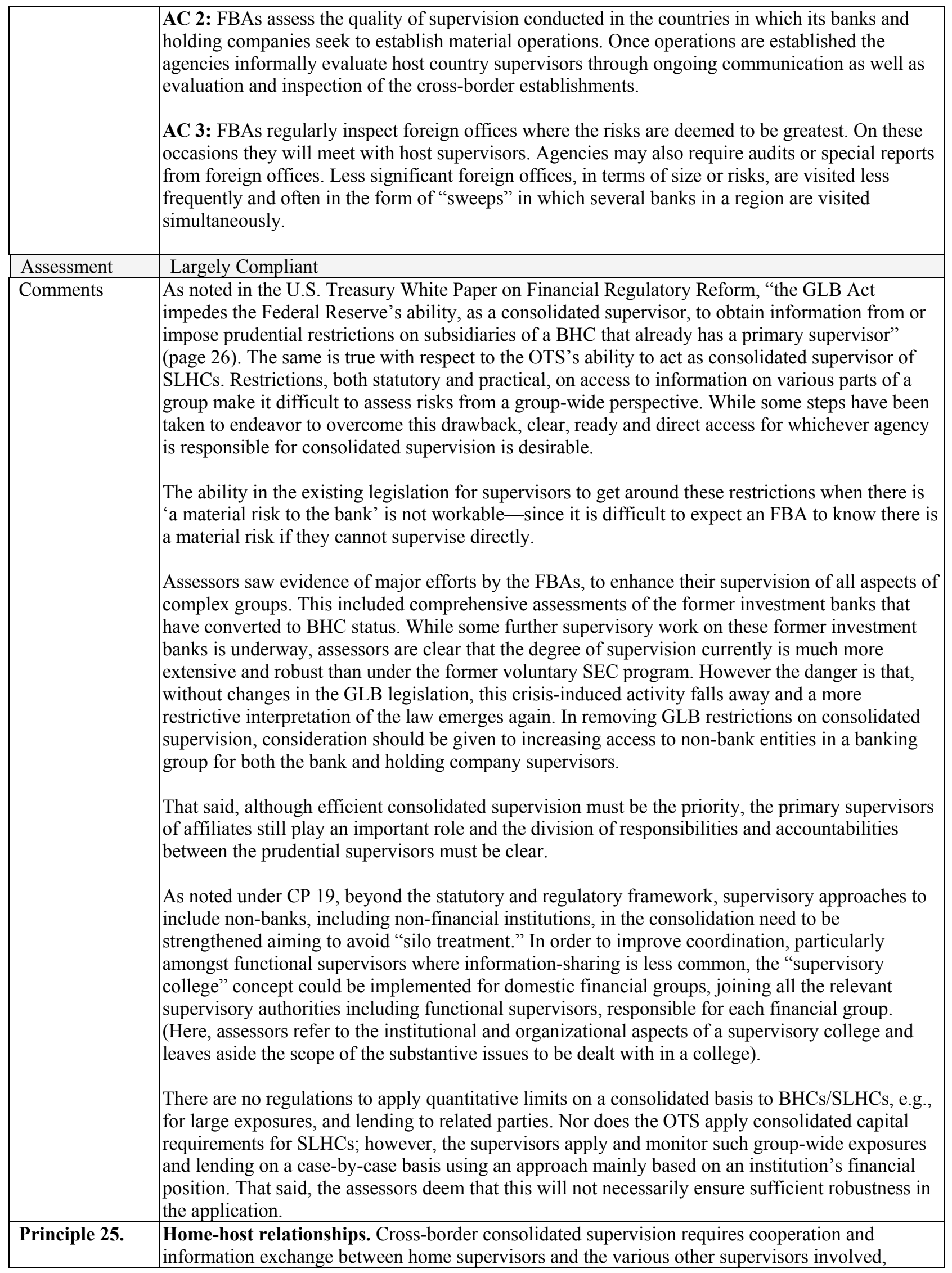




\begin{tabular}{|l|l|}
\hline Description & $\begin{array}{l}\text { primarily host banking supervisors. Banking supervisors must require the local operations of } \\
\text { foreign banks to be conducted to the same standards as those required of domestic institutions. }\end{array}$ \\
EC 1: As discussed in Principle 1(6) the FBAs have clear authority, although subject to the \\
limitation of not impinging on the "U.S. interest," to share confidential supervisory information \\
with foreign banking and other sector supervisors. The information must be used for lawful \\
supervisory purposes, and the recipients must keep the information confidential. FBAs provide \\
adequate data and information to host country supervisors about U.S. banks and holding \\
companies, to enable the host country to supervise the overseas operations of the U.S. banks. The \\
FBAs have ongoing contact with supervisors in other countries in which U.S. banks have material \\
operations, including periodical visits to discuss supervisory issues. Information sharing by U.S. \\
agencies as both home and host supervisors involves sharing significant supervisory concerns and \\
supervisory documents; providing information to assist with the authorization process and with \\
investigations; discussing and coordinating supervisory plans and strategies; managing and \\
participating in bilateral and multilateral meetings; developing joint enforcement actions; and \\
participating in "colleges." Additionally, U.S. supervisors visit foreign supervisory authorities to \\
discuss supervisory issues.
\end{tabular}

EC 2: Typically, the FBAs identify other relevant supervisors at the time a banking organization seeks authority, or provides notice of its intent, to establish operations in a foreign jurisdiction. The agencies will establish formal or informal arrangements, as appropriate, for sharing of information regarding the bank's operations in the home or host country. Such arrangements are made available to the public through the Freedom of Information Act process. The existence of institution- or group-specific arrangements is disclosed to the involved bank but is not otherwise made publicly known. Information sharing arrangements are in place with supervisors in many foreign jurisdictions and more are in process. These arrangements are not required by law, but they support the agencies' efforts to oversee the operations of U.S. banks abroad and foreign banks operating in the US. There is also an informal system which relies on peer-to-peer contact.

EC 3: The FBAs provide information to host supervisors in response to specific requests regarding their supervision. This applies to the conduct of actual supervision and to descriptions of developments to the framework of supervision. They also provide information on significant problems which may have a material effect on the subsidiaries or branches in the host country. As appropriate, there is also cooperation during the licensing process, in the supervision of ongoing activities, and in the handling of problem banks. FBAs endeavor to inform host country supervisors in a timely manner about events that could endanger the stability of the cross-border establishments in the host country. If deemed relevant for the host country affiliate, the agencies also inform host country supervisors when penalties have been imposed or enforcement actions have been taken against a U.S. bank or holding company. However, according to U.S. legislation, U.S. authorities may not act against "the U.S. interest."

EC 4: As host country supervisors the agencies cooperate with the home country supervisors of FBOs with U.S. banking operations in order to facilitate the consolidated supervision. Under the FBO Supervision Program the Federal Reserve and the OCC provide copies of essential supervisory products to home country supervisors. This includes the comprehensive annual assessment of the combined U.S. operations of the FBO. Where specifically requested by the home authority supervisors, copies of examination reports of an FBO's U.S. operations may also be provided to them. If deemed to have a potentially material impact on the parent bank, the agencies will apprise home supervisors of significant concerns and impending supervisory actions. The actions taken on liquidity issues during the recent crisis is a typical example of situations leading to cross-border communications and, indeed in many cases, international coordination.

EC 5: The International Banking Act (IBA) provides for "national treatment" of foreign banks doing business in the United States (Also savings associations owned or controlled by FBOs are subject to "national treatment"). Hence, the U.S. law generally accords the same treatment to FBOs as it does to domestic banks. However, a number of regulations do not apply to FBOs that do not have U.S. retail operations. Vice versa, there is a requirement for FBO branches in the United 


\begin{tabular}{|c|c|}
\hline & 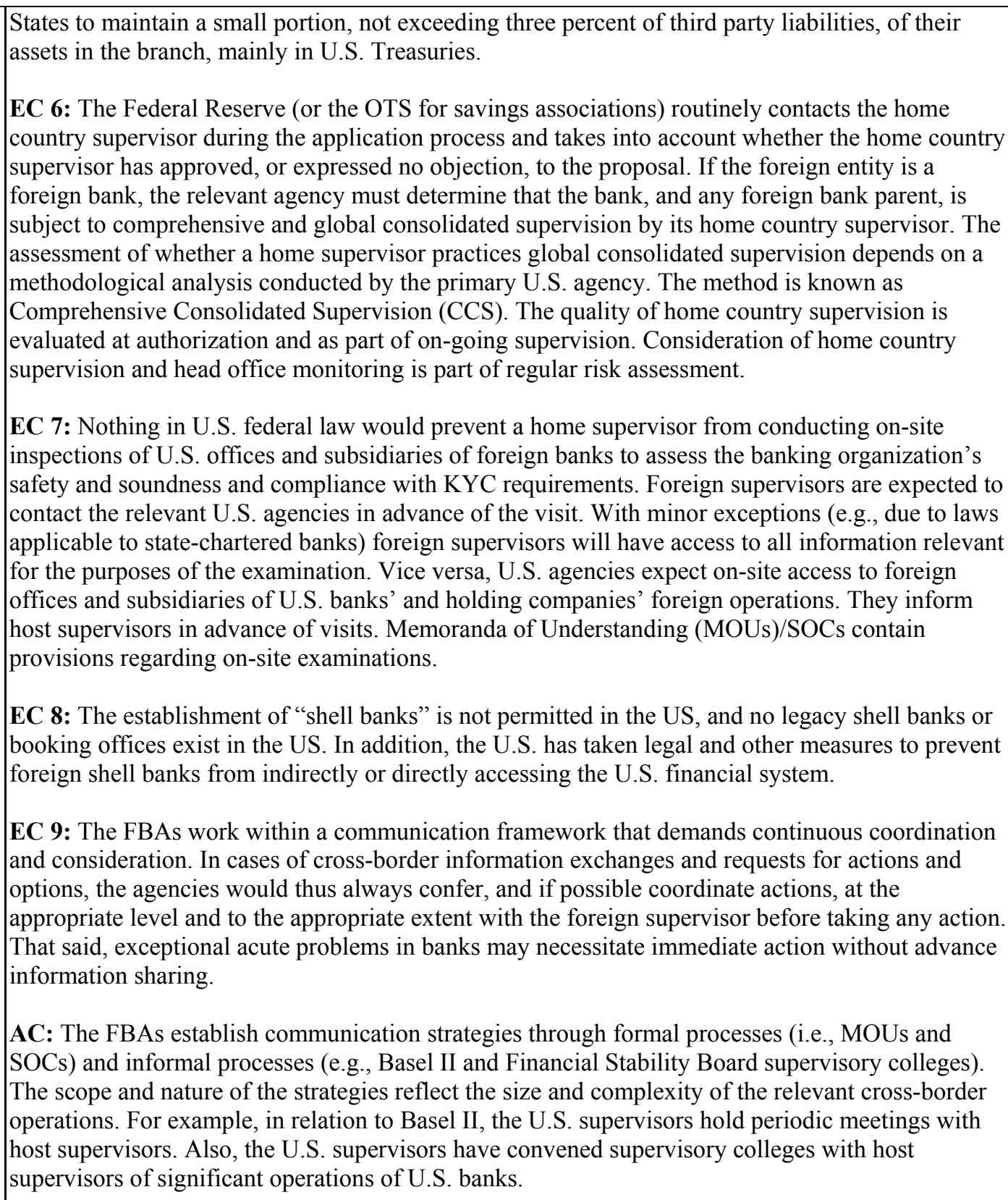 \\
\hline Assessment & Compliant \\
\hline Comments & $\begin{array}{l}\text { The concept of "in the U.S. interest" should be interpreted broadly by the U.S. authorities. For } \\
\text { example, it would in many cases be in the U.S. interest to obtain a solution for the whole } \\
\text { international financial group, working together with foreign authorities, rather than "ring-fencing" } \\
\text { the U.S. operations and thus aggravating the problems of the group as a whole. }\end{array}$ \\
\hline
\end{tabular}




\section{Recommended Action Plan and Authorities' Response}

\section{Recommended action plan}

\section{Table 3. Recommended Action Plan to Improve Compliance with the Basel Core Principles}

\begin{tabular}{|l|l|}
\hline \multicolumn{1}{|c|}{ Reference Principle } & \multicolumn{1}{|c|}{ Recommended Action } \\
\hline $\begin{array}{l}\text { 1. Objectives, independence, powers, transparency, and } \\
\text { cooperation }\end{array}$ & $\begin{array}{l}\text { Consider formally setting out the mandate and } \\
\text { objectives of the FBAs in legislation. Ensure core safety } \\
\text { and soundness mandates and individual accountability } \\
\text { for each FBA are clear. Clarify expectations and } \\
\text { accountability for the primary federal bank regulator } \\
\text { and the holding company regulator as they are } \\
\text { inextricably linked in the case of large complex banking } \\
\text { groups. }\end{array}$ \\
\hline 1.1 Responsibilities and objectives & $\begin{array}{l}\text { Strengthen inter-agency coordination of supervisory } \\
\text { processes, pursue opportunities for: more integrated } \\
\text { supervision planning; more commonality of forward- } \\
\text { looking risk rating systems, more sharing of off-site } \\
\text { surveillance methodology and results, and more joint } \\
\text { reviews. }\end{array}$ \\
\hline $\begin{array}{l}\text { Develop a more forward-looking detailed resource plan } \\
\text { that takes account of risk assessments, lessons learned, } \\
\text { and new and existing priorities. Focus senior } \\
\text { governance within and between agencies on } \\
\text { improvements in supervisory process. Improve public } \\
\text { performance reporting. Alter the governance rules at } \\
\text { Reserve Banks to remove appearance of industry } \\
\text { influence. Raise threshold for triggering material loss } \\
\text { reviews and consider the themes from those reviews } \\
\text { (e.g., timeliness and forcefulness of intervention) to } \\
\text { improve performance. }\end{array}$ \\
\hline $\begin{array}{l}\text { Strengthen channels for cooperation, coordination, and } \\
\text { learning from best practices-within and between } \\
\text { FBAs and functional supervisors. }\end{array}$ \\
\hline
\end{tabular}




\begin{tabular}{|c|c|}
\hline Reference Principle & Recommended Action \\
\hline 3. Licensing criteria & $\begin{array}{l}\text { Strengthen interagency agreement to prevent } \\
\text { inappropriate charter conversions. Monitor } \\
\text { developments to see if said agreement needs further } \\
\text { strengthening. } \\
\text { Deepen assessment and presentation to chartering } \\
\text { decision-makers on the operational plan for the } \\
\text { applicant bank. } \\
\text { Increase the (absolute) minimum capital requirement } \\
\text { for new banks }\end{array}$ \\
\hline 6. Capital adequacy & $\begin{array}{l}\text { Work with the BCBS and domestically to strengthen } \\
\text { the definition of what counts as Tier 1/core capital } \\
\text { especially for holding companies. Revisit ability for } \\
\text { banks and thrifts to have a large part of their Tier } 1 \\
\text { capital composed of intangibles by capping the } \\
\text { percentage allowed at a lower level. Put in place formal } \\
\text { capital rules for SLHCs. }\end{array}$ \\
\hline 7. Risk management process & $\begin{array}{l}\text { Conduct regular inter-agency horizontal detailed } \\
\text { assessment of all risk monitoring, management and risk } \\
\text { governance improvements at major complex banking } \\
\text { groups. Include detailed testing of the robustness of } \\
\text { improvements. Include all large complex banking } \\
\text { organizations in these regular assessments. Publish } \\
\text { regular reports and guidance to reinforce supervisory } \\
\text { expectations. Ensure adequate ongoing resources for } \\
\text { these reviews. }\end{array}$ \\
\hline 8. Credit risk & $\begin{array}{l}\text { Develop a clear comprehensive strategy to reduce the } \\
\text { extent and severity of credit risk problems resulting } \\
\text { from a future credit cycle and building on (and } \\
\text { extending across agencies) improvements in credit risk } \\
\text { monitoring and surveillance already started. This } \\
\text { strategy should address: timeliness and forcefulness of } \\
\text { supervisory interventions, timeliness of guidance, } \\
\text { revisiting whether guidance needs to occasionally } \\
\text { contain specific limits to be effective, consistency of } \\
\text { follow-up on new guidance; ability of the FBAs to } \\
\text { intervene to make their views known about systemic } \\
\text { weaknesses in credit risk management practices or in } \\
\text { contributing polices that they do not control but that } \\
\text { may need to be addressed by authorities more broadly; } \\
\text { strengthen inter-agency processes to enhance collective } \\
\text { assessment of emerging problems; and, ensure that } \\
\text { sufficient specialist resources are available to assess } \\
\text { complex credit risk matters in smaller and mid-size, as } \\
\text { well as larger banks. }\end{array}$ \\
\hline
\end{tabular}




\begin{tabular}{|c|c|}
\hline Reference Principle & Recommended Action \\
\hline 10. Large exposure limits & $\begin{array}{l}\text { Include all exposures within the limits and reporting of } \\
\text { large exposures. Strengthen reporting requirements on } \\
\text { large exposures. Advance supervisory guidance further } \\
\text { on sectoral and geographical concentration risk } \\
\text { identification and management. }\end{array}$ \\
\hline 11. Exposure to related parties & $\begin{array}{l}\text { Strengthen regulations on board oversight and } \\
\text { involvement. Enhance reporting requirements to board } \\
\text { and to the supervisors. Lower the current limit on the } \\
\text { aggregate amount of loans to all insiders. (It now equals } \\
\text { a bank's own funds plus "surplus" funds.) Incorporate } \\
\text { all exposures to insiders (and affiliates) in the definition } \\
\text { of insider transactions and in the limits. }\end{array}$ \\
\hline 13. Market risks & $\begin{array}{l}\text { Complete the current horizontal assessment of the } \\
\text { Market Risk Amendment and determine how much } \\
\text { further in-depth horizontal review of market risk and } \\
\text { valuation improvements at major banks is required. } \\
\text { Conduct regular, horizontal, in-depth assessments of } \\
\text { banks' progress in market risk enhancements. }\end{array}$ \\
\hline 14. Liquidity risk & $\begin{array}{l}\text { Make sure the crisis-driven improvements in banks and } \\
\text { supervisors liquidity risk processes are transitioned into } \\
\text { organized, sustainable, improved liquidity risk } \\
\text { management and supervisory monitoring and } \\
\text { assessment. Update the supervisory program, and } \\
\text { conduct regular supervisory assessments of risk } \\
\text { management and crisis and contingency plans at banks. }\end{array}$ \\
\hline 15. Operational risk & $\begin{array}{l}\text { Consider a more holistic and structured approach to } \\
\text { operational risk assessment, utilizing enhanced cross- } \\
\text { agency mechanisms. }\end{array}$ \\
\hline 16. Interest rate risk in the banking book & $\begin{array}{l}\text { Consider the capacity to improve the assessment of } \\
\text { interest rate risk by introducing a more consistent } \\
\text { measurement approach. }\end{array}$ \\
\hline 18. Abuse of financial services & $\begin{array}{l}\text { Rectify certain CP 18-relevant deficiencies as identified } \\
\text { by the FATF. }\end{array}$ \\
\hline 19. Supervisory approach & $\begin{array}{l}\text { Improve the capacity for group-wide oversight of } \\
\text { financial groups, including unregulated entities. } \\
\text { Introducing domestic "supervisory colleges" involving } \\
\text { all main regulators (not just the FBAs) of major } \\
\text { banking groups may assist, although broader reform is } \\
\text { necessary. An overhaul of risk rating systems, with a } \\
\text { view to improve their capacity to distinguish between } \\
\text { banks, is also recommended. }\end{array}$ \\
\hline 20. Supervisory techniques & $\begin{array}{l}\text { Review, perhaps under the auspices of the FFIEC, } \\
\text { existing supervisory manuals and processes to remove } \\
\text { unnecessary differences and develop a "best of breed" } \\
\text { approach. }\end{array}$ \\
\hline
\end{tabular}




\begin{tabular}{|l|l|}
\hline \multicolumn{1}{|c|}{ Reference Principle } & \multicolumn{1}{|c|}{ Recommended Action } \\
\hline 21. Supervisory reporting & $\begin{array}{l}\text { Review the solo reporting requirements to ensure } \\
\text { prudential requirements can be monitored relative to an } \\
\text { individual bank's balance sheet. Also consider the } \\
\text { implications of U.S. GAAP for the effectiveness of } \\
\text { supervision and the PCA regime. }\end{array}$ \\
\hline 22. Accounting and disclosure & $\begin{array}{l}\text { Consider the introduction of statutory reporting } \\
\text { ("whistleblower") obligations for external auditors, } \\
\text { along with associated protections. }\end{array}$ \\
\hline 24. Consolidated supervision & $\begin{array}{l}\text { Make changes in legislation and practices to ensure } \\
\text { effective conduct of consolidated supervision of } \\
\text { financial groups. Also, regulatory limits and reporting } \\
\text { of adherence to those should be introduced on the } \\
\text { consolidated group level, including at the holding } \\
\text { company level, for large exposures, and related lending. }\end{array}$ \\
\hline
\end{tabular}

\section{Authorities' response to the assessment}

66. The U.S. authorities wish to express their appreciation to the IMF and its assessment teams for the dedication, time and resources committed to this assessment. The authorities strongly support the Financial Sector Assessment Program, which promotes the soundness of financial systems in member countries and contributes to improving supervisory practices around the world. The U.S. assessment has presented a challenging and complex task, and the IMF has worked professionally and in a spirit of collaboration to produce the assessment. The U.S. authorities appreciate the opportunity to provide the following comments.

67. As recognized by the Report, it is important to consider the U.S. assessment in context. The assessment follows in the wake of a severe financial crisis and economic downturn, and these severe stresses have tested the resilience of the U.S. financial sector and its supervisory framework. The assessment properly holds the United States to a higher standard, given the maturity, complexity, and significance of our financial sector. Additionally, it is important to recognize that the United States is the first highly complex economy to have been evaluated under the Core Principles as updated in 2006. The revised Core Principles place a greater emphasis on risk management, and the methodology requires assessors to consider the practices of banks as well as the policies and practices of banking agencies. The authorities are pleased that, even under these more stringent Core Principles, and when applying a higher standard to the complex U.S. financial system, the IMF's assessment of the U.S. system is that it is broadly in compliance with the Core Principles. The few areas that are identified for improvement are acknowledged and are recognized; much is underway to address these known concerns.

68. The Report acknowledges that, while many of the identified weaknesses are being addressed by the U.S. federal banking agencies and by legislative reforms, it was not possible for the assessment to incorporate, or give credit for, these actions or reforms. For example, 
the Report acknowledges that a number of the firms that experienced major problems (i.e., the government sponsored enterprises and various investment banks before they became BHCs) were not subject to oversight by any of the federal banking agencies and that failures in risk management at these companies were a major contributor to the financial crisis. The U.S. federal banking agencies have, in multiple forums, expressed their desire to move forward expeditiously with legislative changes to address identified concerns.

69. Aside from supporting legislative reforms the U.S. federal banking agencies are making substantial progress in the oversight of risk management practices. Initiatives related to credit, market, and liquidity risk, and consolidated supervision are recognized in the Report. These changes, combined with proposals for legislative reforms that would enhance the ability to supervise institutions on a consolidated basis, address many of the deficiencies cited. It is equally important, however, to acknowledge that actions supervisors took as the magnitude of the crisis became clear and have continued to take since the crisis, are at least as important in judging the supervisors' effectiveness as any assumptions made about their oversight based on risk management weaknesses of supervised institutions. For these reasons, and for reasons noted earlier, the U.S. authorities take issue with the "Materially Non-Compliant" rating for CP 7, Risk Management Process.

70. The authorities believe each FBA has both statutory and organizational mandates and objectives which are clear and do provide specific roles and authority for the conduct of supervision of regulated entities. In addition, each agency has very specific authority to take steps to compel organizations to make improvements in risk management and other processes and as noted in the DAR we are actively working with institutions to improve these processes as well as regulatory policy in these same areas.

71. The IMF's assessment of CP 6, the Capital Adequacy standard, as Largely Compliant does not fully reflect aspects of U.S. bank supervision, both immediately before the crisis and once the crisis emerged. U.S. banks are held to a higher capital standard than international standards because of U.S. Prompt Corrective Action law and regulation. Currently, approximately 96 percent of U.S. banks, representing approximately 99 percent of total bank assets, hold 50 percent or more capital than international minimums. In addition, the quality of capital held by U.S. banks has generally been higher than in many other jurisdictions. Prior to the crisis most U.S. banks, including the largest, had Tier 1 capital composed mostly of common equity (80-90 percent or higher). In contrast, banks in other countries had common equity levels closer to the Basel predominance standard of 50 percent common shareholders' equity with the remaining component of Tier 1 capital generally consisting of tax-deductible hybrid securities. Moreover, as a result of the Supervisory Capital Assessment Program (SCAP), the largest U.S. banks now have risk-based ratios of Tier 1 capital and Tier 1 common equity that far exceed Basel minimum capital requirements.

72. Finally, the federal banking agencies have taken a number of substantive actions that are not fully reflected in the Report. These include: 
- The SCAP stress assessment on the 19 largest bank holding companies, which together hold two-thirds of the assets and more than one-half of the loans in the U.S. banking system. The SCAP was notable among stress tests conducted by other countries in its scope, rigor, intensity, breadth, and transparency, and resulted in large banks raising a substantial amount of common equity capital which strengthened the level and quality of bank capital in the United States;

- Joining international efforts to initiate supervisory colleges for large, globally active U.S. banks;

- Directing large banks to improve their ability to aggregate risks across legal entities and product lines to identify potential risk concentrations and correlations, and requiring improved contingency funding plans;

- Conducting targeted, leveraged lending reviews at the largest syndication banks, focusing on syndicated pipeline management, stress testing, and limit setting

- Conducting high quality implementation of Basel II;

- Issuing and implementing interagency guidance on subprime and non-traditional mortgages; and

- Initiating new data gathering, e.g., a project that provides data on over 60 percent of residential mortgages serviced in the United States.

73. The U.S. authorities appreciate the Report's recommendations, and will review them carefully. They will take action where they have authority, including in the areas of enhancing communication and information-sharing among the agencies, ensuring more effective oversight of systemic risks, and requiring increased liquidity buffers at systemically important institutions. They look forward to a continuing dialogue as they jointly seek to improve the stability and effective supervision of the global financial services sector. 